HUSZÁR ORSOLYA

\title{
AZ ELVONULÁS MINT KOMMUNIKÁCIÓS SZÍNTÉR \\ FELKÉSZÜLTSÉGEK ÉS PROBLÉMAMEGOLDÁS \\ EGY BUDDHISTA KÖZÖSSÉGBEN
}


MAGATARTÁSTUDOMÁNYI ÉS KOMMUNIKÁCIÓELMÉLETI INTÉZET

Témavezető:

Dr. Karácsony András, Csc

habil. egyetemi tanár

(C) Huszár Orsolya, 2017 
BUDAPESTI CORVINUS EGYETEM

TÁRSADALMI KOMMUNIKÁCIÓ DOKTORI ISKOLA

\section{AZ ELVONULÁS MINT KOMMUNIKÁCIÓS SZÍNTÉR \\ FELKÉSZÜLTSÉGEK ÉS PROBLÉMAMEGOLDÁS \\ EGY BUDDHISTA KÖZÖSSÉGBEN}

Doktori értekezés

Huszár Orsolya

Budapest, 2017 



\section{Tartalomjegyzék}

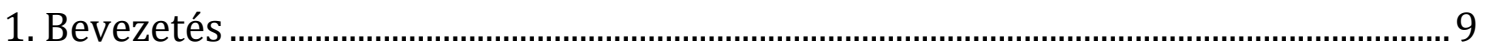

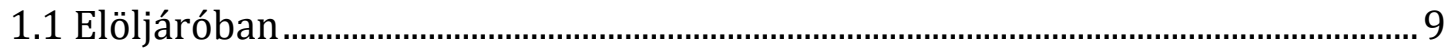

1.2 Az elméleti keretről és a kutatási módszerekről.................................................... 10

1.3 Az értekezés pozicionálása ...................................................................................... 12



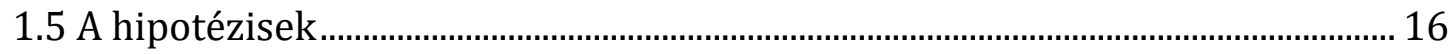

1.6 A fóbb következtetések................................................................................................ 18

2. A kommunikáció intézményei …………………………………………………………....21

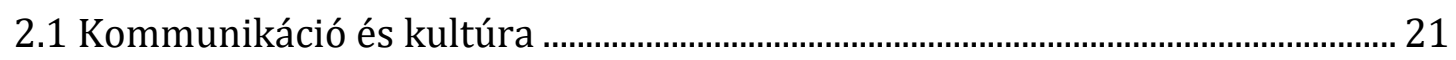

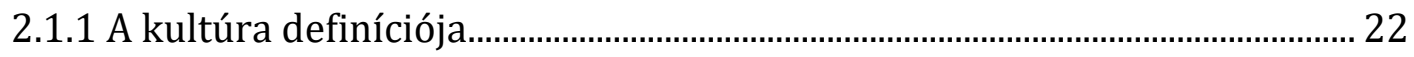

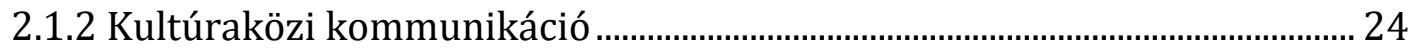

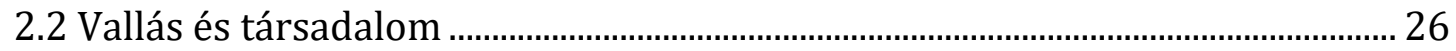

2.2.1 A vallás fogalmi tárgyalásának lehatárolása ....................................................26

2.2.2 A történelem-/kultúraalapú értelmezések......................................................... 26

2.2.3 Kortárs és kitágított értelmezések .................................................................... 30

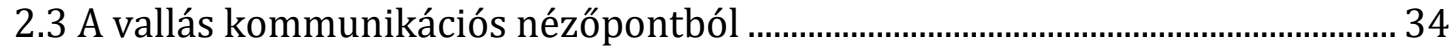

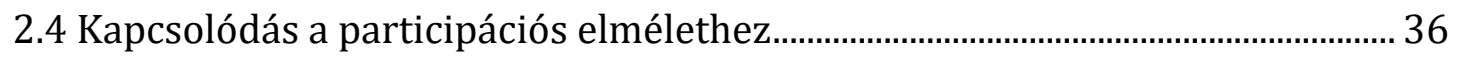

2.4.1 Meghatározások .................................................................................................. 37

2.5 A buddhizmus Nyugaton: sokszínű kapcsolatok.................................................. 39

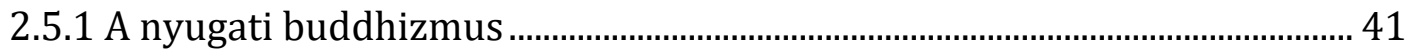

2.5.1.1 Elkötelezett buddhizmus.............................................................................. 49

2.5.2 A nyugati és keleti gondolkodás a vallások tükrében ...................................... 51

2.5.3 A buddhizmus és a tudomány kapcsolódása .................................................. 54

2.5.3.1 A pszichológia, kognitív tudomány és a buddhizmus határterületei 56

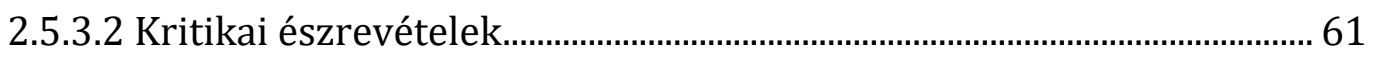

2.5.4 Az „Easternization thesis” és kritikája ................................................................. 62

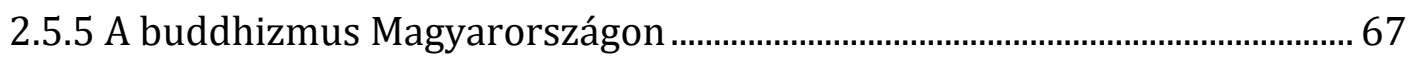

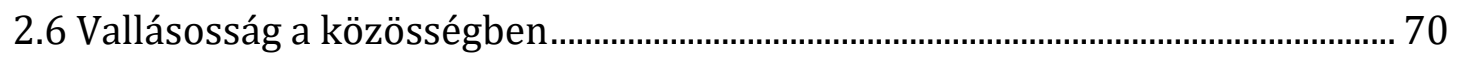

2.7 Nyelv és megértés ....................................................................................................... 78

2.7.1 Az együttérzés, szerető kedvesség és szeretet fogalma .................................. 82 


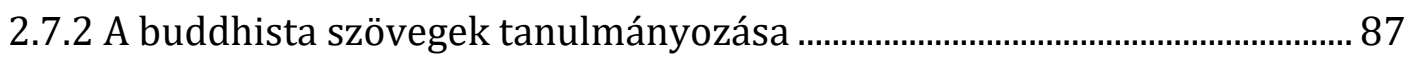

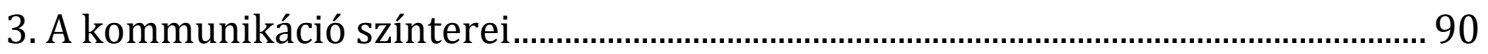

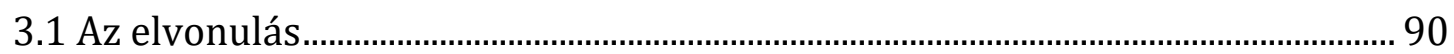

3.1.1 Az elvonulás Thich Nhat Hanh franciaországi közösségében....................... 91

3.1.2 A terepmunka - résztvevő megfigyelés.............................................................. 93

3.2 A szent (szakrális) tér, a szimbolizációs eszközök és a rítusok ........................... 99

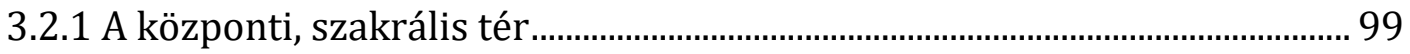

3.2.2 Szimbolizációs eljárások és eszközök ...........................................................104

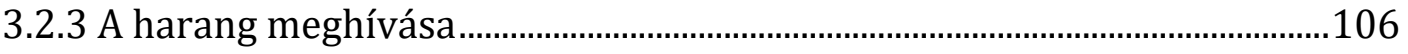

3.2.4 A füstölő felajánlása ..........................................................................................107

3.2.4.1 A rítus különféle megközelítései ...............................................................107

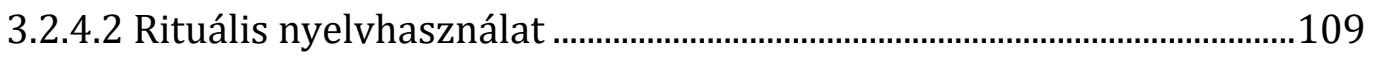

3.2.4.3 A felajánlási rítus.........................................................................................111

3.2.4.4 A menedékvétel ........................................................................................112

3.2.4.5 Az Ősök-szertartás ..........................................................................................114

3.3 Mit jelentenek a szangha rítusai, szertartásai a résztvevők számára? ...........115

3.4 Mit jelentenek az elvonulások a résztvevők számára? .......................................119

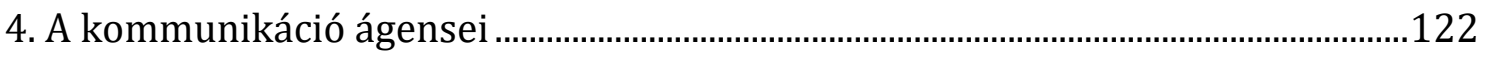

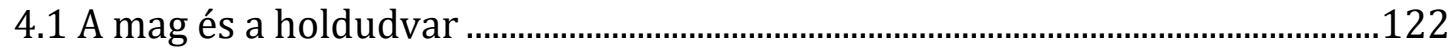

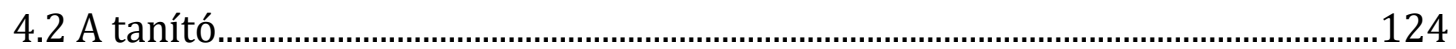

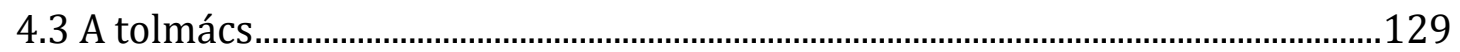

4.4 Problémamegoldás a hétköznapokban ................................................................136

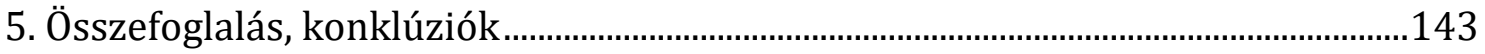

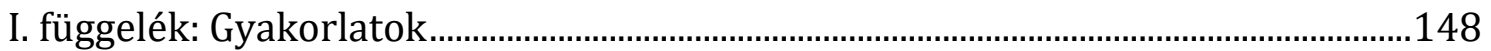

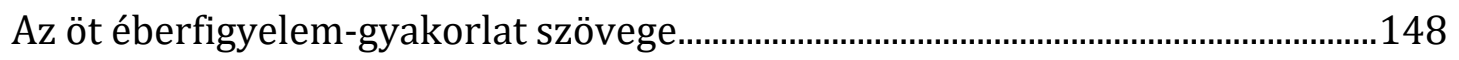

A föld három érintése gyakorlat..................................................................................151

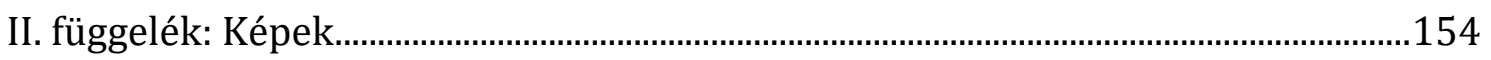

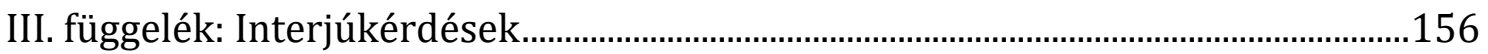

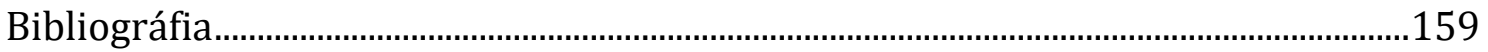

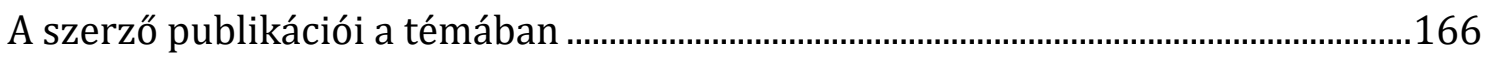




\section{A képek jegyzéke}

1. kép: Oltár a Tan Kapuja Buddhista Főiskola Szertartástermében .......................... 154

2. kép: A zendó elrendezése Dharma-tanításhoz ……………………………………...... 154

3. kép: Oltár a zendóban Pannonhalmán ......................................................................... 154

4. kép: Thich Nhat Hanh képe a pannonhalmi zendóban ............................................ 154

5. kép: Programra hívó harangok Pannonhalmán ........................................................... 155

6. kép: Átmeneti tér a szakrális térbe való belépés előtt............................................. 155

7. kép: Az Ôsök-szertartáshoz berendezett zendó egy részlete................................... 155

8. kép: Dharma-tanításhoz berendezett zendó Budapesten, a Tűzmadár Házban .... 155

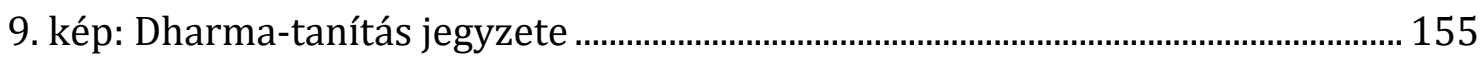

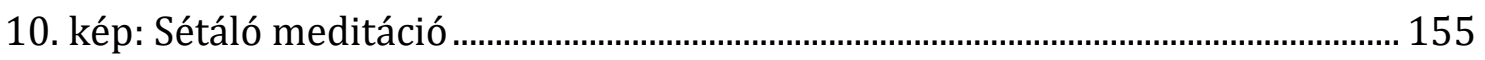




\section{Köszönetnyilvánítás}

Szeretnék köszönetet mondani a Szelíd Mosoly Buddhista Szangha minden tagjának a szeretetteljes befogadásért és elfogadásért, Jan Boswijknak, Hilly Bolnak és Cuong Lunak pedig a gondolatébresztő tanításokért. Külön is szeretném megköszönni mindazok nyitott és érdeklődő rendelkezésre állását, akik a mélyinterjúk elkészítésében a segítségemre voltak. Nélkülük ez az értekezés nem születhetett volna meg.

Köszönöm továbbá a családomnak és a munkatársaimnak azt a támogatást, amelynek hiányában nem tudtam volna a kutatásra és az írásra koncentrálni. 


\section{Bevezetés}

\subsection{Elöljáróban}

Nem mondhatjuk, hogy a modern kor embere az első, aki nemcsak saját - szűkebb vagy tágabb - környezetének kultúrájával találkozik, hiszen a kultúrák érintkezése már évezredek óta zajlik. A globalizálódó világ azonban meglehetősen új kihívásokat állít elénk, miközben újra és újra meg kell küzdenünk azokkal a problémákkal is, amelyekkel már elődeink is szembesültek. Az ember elsődlegesen saját környezetének, társadalmának a része, szocializációs-tanulási folyamata során mindenekelőtt ennek gondolkodásmódját, értékeit, viselkedésmintáit és hiteit sajátítja el. A korábbi korokhoz képest azonban napjainkban az ember jóval intenzívebben találkozik - közvetlenül és az információs társadalom adta lehetőségek révén - más kulturális mintákkal, értékrendekkel, és a fejlett társadalmak tagjai jellemzően nagyobb szabadsággal építhetik be ezeket saját világnézetükbe, mindennapjaikba.

Az összefonódás az élet számos területén tapasztalható: gazdasági-politikai kapcsolatok formájában éppúgy, mint kulturális téren; ma már nem okoz gondot akár naponta más-más országból érkezett zenészeket hallgatni, filmeket nézni, személyesen is találkozni a legkülönfélébb nációk tagjaival. A dolgokat azonban mindig kultúránk és tapasztalataink szűrőjén keresztül látjuk: ha például leül egy szudáni, egy kínai és egy francia fiatal, hogy megvitassák a demokrácia kérdését, bármennyire is nyitott szelleműek, és még ha mindannyian rendelkeznek is e fogalom jelentéséről valamifajta elképzeléssel vagy tudással, bizonyára nem teljesen ugyanazt fogják érteni rajta.

Az iménti példa, vagyis a 'demokrácia' egy olyan fogalom, amely specifikusan kötődik adott társadalmi-politikai fejlettséghez, alakulathoz, tehát igen könnyen el tudjuk képzelni, hogy valaki számára ez nem hordoz semmiféle jelentést. Azonban vannak - Kantot idézve - az észnek „megkerülhetetlen feladatai”, olyan tárgyai, amelyek egyetemes jelleggel foglalkoztatják (vagy foglalkoztatniuk kellene) az embert, bármely korban vagy földrészen éljen is. Úgy találjuk, hogy a vallás ilyen tárgy: nem tudunk olyan messzire visszamenni az általunk valamelyest is ismert történelemben, hogy ne találkoznánk a vallás nyomaival. Az ember jellemzője, hogy 
képes reflektálni önmagára, rendelkezik időérzékkel, így óhatatlanul szembesül a lét és a halál, az élet értelme kérdéseivel, e szembesülés pedig szükségszerűen válaszkísérleteket hoz magával. Ma a tudomány korát éljük, és a tudomány is szolgál elméletekkel a világ és benne az ember keletkezését, fejlődését, világban való helyét illetően, azonban ezek nem teljesen kielégítőek mindenki számára, nem feltétlenül adnak magyarázatot az olyan jelenségekre, mint például az erkölcsi gondolkodás. E téma jelentősége tehát kétségbevonhatatlan, amit az is jelez, hogy számos tudományág vizsgálja a saját perspektívájából: például a filozófia, a szociológia vagy a kulturális antropológia és - elsőre talán meglepő módon - a kommunikációelmélet is.

\subsection{Az elméleti keretről és a kutatási módszerekről}

Az értekezés a fentieknek megfelelően interdiszciplináris. Ennek egyik oka, hogy a fő keretet a kommunikáció (és különösen annak participációs elmélete) adja, amely maga is tekinthető tudományos határterületnek, amennyiben olyan (társadalmi) intézményeket vizsgál és vesz számításba, mint a nyelv, kultúra, művészet, jog, tudomány, moralitás, vallás, politika, gazdaság. ${ }^{1}$ A dolgozat ezek közül elsősorban a nyelv, kultúra, vallás és tudomány intézményeit tárgyalja. A kommunikációelméleten kívül a vallástudomány, szociológia, kulturális antropológia, nyelvészet területéről származó elméletek, megközelítések, kutatási eredmények is felhasználásra kerültek, valamint szóba kerül a pszichológia és az idegtudomány buddhizmussal való kapcsolata is. A téma miatt nem kerülhetők meg bizonyos filozófiai megfontolások sem, különösen a fenomenológia és a buddhista filozófia köréből.

A gyakorlati kutatás során szintén több módszert kellett felhasználnom. Egyrészt kulturális antropológiai megközelítéssel, a résztvevő ${ }^{2}$ megfigyelés módszerével végeztem terepmunkát egy magyarországi buddhista közösségben.

\footnotetext{
1 „A kommunikáció sohasem önállóan, más társadalmi jelenség, összefüggés kizárásával van. Mindig valahol, valamikor és még más módon is beszövött a kommunikátor személyes és/vagy a társadalom intézményi valóságába." (Horányi [2006], p. 11.)

${ }^{2}$ A 'résztvevő' kifejezést az antropológiában meghonosodott módon, egybeírva használom.
} 
A kulturális antropológia önmagában is interdiszciplináris terület, ahogy Kézdi Nagy Géza írja:

„A kulturális antropológia elkülönülése más társadalomtudományoktól elsősorban a megközelítésben, a szemléletmódban és a módszerekben nyilvánul meg. Az antropológusok nem nélkülözhetik a széles látókörűséget, speciális tapasztalataikat felhasználva alkalmazzák más társadalomtudományok módszereit és eredményeit is. A holisztikus szemléletmód lehetőséget nyújt egyfajta komplexebb elemzésre, az összehasonlító szemléletmód pedig segít a kutatási eredmények rendszerezésében és viszonyításában. Fontos a kulturális relativizmus koncepciója az antropológus számára, hiszen más népek viselkedését nem a saját normáink alapján kell megítélnünk, hanem saját terminusain belül kell elemezni, mivel minden életmód egyedi. Tehát törekedni kell a tanulmányozott társadalom szubjektív megértésére is. Ez a szubjektív megértés, vagy ahogyan általában nevezik, az émikus módszer az empátián, azaz a beleélésen alapszik. $\mathrm{Az}$ antropológus gondolatilag belehelyezi saját magát a vizsgált csoport körülményeibe, magáévá teszi logikájukat és értékorientációikat, és ily módon ítéli meg magatartási válaszaikat. Ugyanakkor ennek párjaként a feldolgozáskor objektíven, vagyis étikus módon rendszerezi, elemzi és tágabb társadalomtudományi összefüggések közé helyezi a kutatási eredményeket.

Elengedhetetlen ebben a tudományágban a terepmunka, mely nélkül az adatgyűjtés és a megértés szinte kivitelezhetetlen. A terepmunkamódszerekben döntő az antropológus beilleszkedése, befogadása után a résztvevő megfigyelés, a helyi nyelv ismerete vagy elsajátítása és a rögzítéstechnikai eszközök (interjúk készítéséhez hangfelvevő, fényképezőgép, videokamera stb.) használata.

Összefoglalva tehát: a kulturális antropológia egy olyan társadalomtudomány, amely társadalmi folyamatokat és társadalmi csoportokat vizsgál a fent említett személettel és módszerekkel, gyakorlatilag »beköltözve« az adott közösségbe, és velük egy adott időszakban együtt élve próbálja megismerni, megérteni és értelmezni kultúrájukat." (Kézdi Nagy [2008], p. 12.)

A függelékben a megértést segítendő ezért található néhány kép is, amelyeket a közösségi élet zavarásának kerülésével, mobiltelefonnal készítettem. Ezeken a szenzitív jelleg miatt résztvevők egyáltalán nem vagy csak nem felismerhetően láthatók, a cél a környezet, valamint különféle (például szertartási) tárgyak bemutatása.

A résztvevő megfigyelés mellett a mélyinterjú eszközét is alkalmaztam. Mivel az értekezés témája nem egyszerűen egy adott közösség leírása, hanem azt igyekeztem feltárni, hogyan tudják e közösség tagjai a mindennapi életükben alkalmazni a vizsgált és más hasonló közösségben, illetve a közösségen kívül, de 
a buddhizmus területén szerzett felkészültségeiket, miként oldják meg a közösségen kívül adódó problémáikat, szükséges volt a közösségi színtéren kívül is információkat gyűjtenem. A mélyinterjú alkalmas eszköz a megkérdezettek motivációinak, értékeinek, érzelmeinek megismerésére egy olyan környezetben, ahol nem befolyásolják őket a társas kapcsolatok. Technikailag az interjúkat különböző helyeken, a megkérdezett választása szerinti, számára komfortos környezetben készítettem (lakás, munkahely, park, kávézó). A beszélgetésekről felvétel készült, amelyet közvetlenül az adott beszélgetés után leiratozam. Összesen 15 interjú készült az elvonulásokon részt vevőkkel és a tolmáccsal. ${ }^{3}$

A kutatás során a szakirodalom ${ }^{4}$ olvasása mellett különféle videókat is megnéztem szertartásokról, tanítók beszédeiről. Ezekről csak érintőlegesen bizonyos kapcsolódások miatt, valamint a téma iránt érdeklődő olvasó számára hivatkozásul - lesz szó, alapvetően a kutató tájékozódását szolgálták.

\subsection{Az értekezés pozicionálása}

A jelen értekezés a buddhizmussal kapcsolatos olyan különféle témákra fókuszál, amelyek kommunikációs nézőpontból, a kommunikáció participációs elmélete által említett bizonyos intézmények, színterek és ágensek vonatkozásában tárgyalhatók. Mivel ez számos, önmagában is nagy területet jelentene, a terjedelmi korlátok miatt szükség van bizonyos szűkítésre. Ez a szűkítés egyrészt a kutató érdeklődését tükrözi, nem pedig az egyes területek jelentőségét (már ha egyáltalán felállítható lenne valamiféle sorrend köztük). Másrészt azonban van egy fontos rendező elv: mindegyik résztéma kapcsolatban van a megértéssel - legyen az nyelvi megértés, vallási-rituális megértés, tudományos megértés stb. - és a megértés révén nyert ismeretek, erkölcsi elvek, attitűdök stb. alkalmazásával, mindennapi életbe való beépítésével, ami átvezet a participációs elmélet alapjához, a problémamegoldáshoz. E résztémák tárgyalása minden esetben tartalmaz bizonyos

\footnotetext{
${ }^{3} \mathrm{Az}$ idézeteknél a megkérdezettek álnéven szerepelnek, a tolmács esetében pedig egybetűs rövidítést alkalmaztam. A megkérdezettek a 30-65 éves korcsoportból kerültek ki, részletesebben lásd az ágensekről szóló fejezetben.

${ }^{4}$ A tudományos irodalom mellett az értekezéshez felhasználtam lelkiségi írásokat, szépirodalmi műveket, valamint buddhista közösségek saját weboldalait és a buddhizmussal kapcsolatos más weboldalakat is. Az ezekre mutató hivatkozások minden érintett helynél szerepelnek.
} 
szintű kitekintést az adott területen folyó kutatásokra, fellelhető elméletekre, kételyekre és kérdésekre, ugyanakkor ezek értelemszerűen nem tudják lefedni az ezen témákban zajló kutatások sokszínűségét és volumenét. Ehelyett inkább megpróbálják bemutatni azt, hogy milyen sokféle lehetőség áll rendelkezésre, ha valaki a buddhizmust a jelenkor kontextusában kívánja vizsgálni, és milyen veszélyeket rejthetnek ezek a vizsgálatok.

Hogy jön mindez a kommunikációhoz, vagy hogy jön mindehhez a kommunikáció? Ha megértésről és alkalmazásról beszélünk, két dolgot mindenképpen hangsúlyoznunk kell. Az egyik, hogy a megértésünket meghatározzák a felkészültségeink és a választásaink. A felkészültségekhez tartozik itt minden, amit „igénybe veszünk” a megértéshez, tehát a nyelvi kompetenciáink, kulturális hátterünk, világnézetünk, az adott témára vonatkozó elméleti tudásunk, a másokkal való kommunikációnkból származó ismeretek, valamint - a témánk tekintetében - például a buddhista tanítások, szertartások, meditációk, gyakorlások során szerzett belátások. Mivel ezeknek a dolgoknak az összetétele, szintje, irányultsága minden ágens esetében más, a megértésben is várhatunk különbségeket. Azonban mégis feltételezhetjük, hogy van közös platform: a kommunikáció segítségével tudjuk tisztázni például azt, hogy pontosan mit is értünk egy-egy fogalom alatt (és itt nem csupán a verbális kommunikációról van szó). Emellett szükségszerűen szelektálunk is az elérhető információkból, megszerezhető ismeretekből, bizonyos dolgokat kiválasztunk, másokat figyelmen kívül hagyunk, a kiválasztott dolgokat pedig igyekszünk valamilyen koherens rendszerré, világnézetté alakítani. Ha esetleg a kognitív disszonancia állapota áll elő, erőfeszítéseket teszünk annak feloldására, nem feltétlenül objektív(nak tűnő) tényezők mentén. A választásaink így hatással vannak a megértésünkre.

A másik hangsúlyozandó dolog, hogy a gyakorlatban való alkalmazásban mindig benne van az adaptálás mozzanata, egyéni, közösségi és össztársadalmi szinten egyaránt. Ez az adaptálás némelykor nehezen észrevehető (vagy rejteni szándékozott), máskor egészen szembetűnő. Van, amikor az adaptálás kifejezett és igényelt, (szinte) problémamentes, mert olyan dolgot érint, amihez kevéssé kötődnek dogmák, tabuk, nagyon bevésődött prekoncepciók, így viszonylagos szabadsággal végezhető el a testre szabás. Vannak azonban olyan területek is, ahol nehéz az adaptálás, akár mert szilárdan rögzült formákról van szó, akár mert 
a dogmák, tabuk stb. miatt nem végezhető el nyíltan. Ilyen eset például az, amikor egy intézmény módosítása megkérdőjelezheti annak legitimitását, megingathatja stabilitását. A vallások esetében például különösen problémás lehet ez, és jelentősebb vagy lényegibb módosításra sokszor csak egyházszakadással és új felekezet (iskola, irányzat) létrehozásával kerülhet sor. Van, amikor ez a folyamat viszonylag békésen zajlik - úgy vélem, a nyugati buddhizmus esetében így történik , máskor akár a felekezetek közötti erőszakos összetűzésekhez is vezethet, amire számos példát láttunk a történelemben, és látunk ma is.

Az adaptálás tekintetében megjelenő egyik legfontosabb kérdés az, hogy mi az az „alap”, amihez nem lehet hozzányúlni anélkül, hogy már ne adaptálásról, hanem egy teljesen új dologról beszéljünk. Ehhez kapcsolódik az a kérdés, hogy ha - tegyük fel - ezt az alapot sikerült is azonosítani és érintetlenül hagyni, az adaptált részek mennyire módosítják az alap értelmezését, és egyáltalán, problémát jelent-e ez. Mint Thészeusz hajójánál: hány deszkát cserélhetünk ki, hogy még mindig ugyanarról a hajóról beszéljünk? Hogy egy kicsit előreszaladjunk: vajon igazi buddhizmus-e a társadalmilag elkötelezett, „aktivistább” természetű nyugati buddhizmus?

Visszatérve a kiindulóponthoz: a dolgozat tehát a megértés, alkalmazás, adaptálás témáját járja körül úgy, hogy a kommunikációt tekinti annak a platformnak, amely - intézményeivel, színtereivel és ágenseivel - lehetővé teszi mindezt. Ehhez a különféle területek irodalma mellett saját kutatást is felhasznál. A cél az, hogy a kutatásból nyert információk, meglátások bekapcsolhatók legyenek az adott területeken folyó diskurzusba. A dolgozatnak tehát nem célja valamiféle önálló elmélet felállítása, sokkal inkább a nyugati buddhizmus (vagyis pontosabban a felé forduló emberek) egy újszerű, kommunikációs szempontú, kifejezetten a participációs elméletre alapozott megközelítésével kíván hozzájárulni a meglévő kutatásokhoz. Az alábbiakban a fő téma és különböző vizsgálható vetületeinek részletesebb kifejtése következik.

Először is: a tárgyalt témakörök horizontálisan és vertikálisan is feloszthatók. A horizontális felosztás annyit tesz, hogy a kommunikáció különféle intézményeit vizsgáljuk a buddhizmussal összefüggésben: a kultúrát, a vallást, a nyelvet és a tudományt. Természetesen a kommunikációnak nemcsak ennyi intézménye létezik, azonban a már említett terjedelmi korlátok miatt itt ezek vizsgálatára kerül csak sor. 
Ezek az intézmények nem egymástól izoláltan működnek, hanem egymással kibogozhatatlanul összekapcsolódva, aminek bemutatása szintén a dolgozat céljai közé tartozik. Vertikálisan az egyén, a (szűkebb) közösség és a társadalom szintjéről lesz szó. Az elvégzett (terep)kutatás az egyén és a közösség szintjét célozta meg, a szakirodalmi feldolgozás pedig részben a társadalom szintjével kapcsolatos, részben pedig mindhárom szint megértését elősegítő fogalmakat, definíciókat, elméleteket tartalmaz. Azt már elöljáróban is szükséges elmondani, hogy több esetben olyan fogalmakról lesz szó (pl. kultúra, vallás), amelyeknél egyetlen fogalom értelmezéseinek és definícióinak felsorolása is megtöltene egy-egy könyvet. A dolgozat szerzője pedig tudatában van annak, hogy választásai befolyásolják az értelmezéseit - így annyit tehet csak, hogy bizonyos óvatossággal jár el a következtetések levonásánál, és e korlátra felhívja az olvasó figyelmét is.

\subsection{Az értekezés témája}

Az értekezés központi kérdése az, hogyan és mennyire sajátítható el és milyen módon használható a mindennapi életvitel támogatására Magyarországon egy idegen kultúrában kialakult, az európai/magyar értékrendtől esetenként távol álló, az itt élő ember számára szokatlan fogalmi apparátust használó, a társadalom egésze által nem adoptált eszmerendszer. A bevezetőben említettem, hogy az élet számos területén találkozunk idegen hatásokkal, sokszor meglehetősen intenzíven, de egy eszmerendszer (nevezzük azt vallásnak, tanításnak vagy filozófiának) tárgyalása abból a szempontból talán izgalmasabb, hogy az általa képviselt értékeket, alapelveket kategorikusabbak gondolhatjuk, mint, mondjuk, ha a munka szféráját néznénk meg ugyanebből a szempontból. Egyrészt azért gondolhatjuk így, mert ha kicsit jobban szemügyre veszünk más kultúrákat, akkor azt találjuk, hogy már ebben a feltételezésben is megjelenik egyfajta értékorientáció: jelesül az individualista felfogás. Kollektivista társadalmak vizsgálatakor az derül ki, hogy ezekben a munka/hivatás kiválasztása jóval kevésbé múlik az egyén önálló vágyain, elhatározásán, és például egy tradicionális kínai család sarja számára az, hogy a szülei akaratának veti alá magát e téren, éppolyan kényszerítő erejű lehet, mint a vallási értékekhez való igazodás. Másrészt azért szükséges a feltételes módot használnunk, mert az értekezésből kitűnik majd - és ez volt a kutatás alapjául 
szolgáló egyik kiinduló (H1) hipotézis -, hogy a tárgyalt vallás, vagyis a buddhizmus (bizonyos korlátokkal) rendelkezik azzal a rugalmassággal, amelynek révén alkalmas lehet a nyugati (és ezen belül a magyar) ember életvitele vezérfonalának.

A H1 hipotézis három alhipotézisre bomlik, amelyek kifejtése később következik, előbb azonban szükséges jelezni néhány dolgot. A bevezetőben volt arról szó, hogy a dolgozat minden résztéma kapcsán tartalmaz bizonyos elméleti kitekintést, valamint gyakorlati kutatást. Az elméleti részben kapnak helyet a használt fogalmak meghatározásai, a történelmi és eszmetörténeti háttér, bizonyos kérdéseknél a jelenlegi kutatási vagy alkalmazási irányok, mindez a terjedelem által korlátozott módon. A számos különböző fogalom és elmélet bemutatásával kifejezett célom a megközelítések sokféleségének érzékeltetése, mindamellett minden témánál jelezni fogom, hogy melyik megközelítést találom célravezetőnek az értekezés szempontjából. A kapcsolódó kutatási anyag pedig e témák kapcsán egy bizonyos magyarországi buddhista közösség értékeit, gyakorlatait, szokásait, önképét, a közösség tagjainak egyedi tapasztalatait és meglátásait tartalmazza. A dolgozatnak ugyan kifejezett szándéka kapcsolatot keresni az elmélet és a gyakorlat között, mindazonáltal nem lép fel azzal az igénnyel, hogy leírja a magyarországi buddhizmus átfogó jelenségét. Amit kínál, az bizonyos betekintés abba, miért érdeklődnek egyes emberek a buddhizmus iránt, mit jelent számukra a buddhista tan és közösség, hogyan tudják beépíteni a mindennapi életükbe a közösségben megszerzett felkészültségeiket. E korlátozott érvényesség ellenére azonban egyértelműen megmutatkoznak majd olyan jellegzetességek, amelyek összhangban vannak a hivatkozott elméleti anyaggal.

\subsection{A hipotézisek}

A H1 hipotézis tehát a következő:

A tárgyalt vallás, vagyis a buddhizmus (bizonyos korlátokkal) rendelkezik azzal a rugalmassággal, amelynek révén alkalmas lehet a nyugati (és ezen belül a magyar) ember életvitele vezérfonalának. 
E hipotézis igazolásához három alhipotézist használok fel:

H1a: $A$ buddhista tan nem vár el olyan szintü kizárólagosságot, mint más vallások, ami a jelenlegi plurális társadalomban önmagában is vonzerôt jelenthet, valamint lehetővé teszi a más vallásokkal/nézetekkel való összeegyeztetést.

H1b: A buddhizmus nyugati ága és azon belül különösen a közösség gyakorlását meghatározó irányzat lehetővé teszi az eltérő szintű elkötelezettséget, bevonódást, sajátos formájú vallásgyakorlást ( „maga módján vallásosságot”), ennek megfelelően pedig összeegyeztethető a modern mindennapi életvitellel.

H1c: A nyelvi és kulturális korlátok nehezítik a megértést és gyakorlást.

A H2 hipotézis a következő: $A$ buddhista közösségben szerzett felkészültségek hatékonyan segítik a problémamegoldást a mindennapi életben.

A hipotézisek bizonyításánál a kommunikáció alábbi intézményeinek tárgyalására kerül sor: vallás, kultúra, nyelv és tudomány. Ehhez elsősorban a témával kapcsolatos szakirodalomra támaszkodom. Az intézmények mellett a kommunikáció színterei, ágensei és az ágensek felkészültségei lesznek az elemzés tárgyai. Ezek esetében a szakirodalom támogató szerepet tölt be a terepkutatás (résztvevő megfigyelés és mélyinterjúk) során nyert meglátások mellett.

A színterek elsősorban azokat az elvonulásokat jelentik, amelyeken kutatómunkám során részt vettem. Ezen belül hangsúlyosan tárgyalom az elvonulások központi terét (a zendót), amely egyben szakrális térként is funkcionál. Ennek kapcsán bizonyos szignifikációk részletesebb kifejtésére is sor kerül. A színtereket a résztvevő megfigyelés alapján írom le.

Ágens egyrészt a közösség mint olyan, valamint ágensek a közösség tagjai, akik négy kategóriába sorolhatók: a tanító (az elvonulás vezetője), a tolmács, a „magot” képező tagok és a holdudvar. Az ágensek kapcsán a $\mathrm{H} 1$ hipotézis további bizonyítására is sor kerül: a tanítónál a $\mathrm{H} 1 \mathrm{a}$, a tolmácsnál a H1c, a mag és a holdudvar tagjainál pedig a $\mathrm{H} 1 \mathrm{~b}$ alhipotézisére. Az ágensek leírása a résztvevő megfigyelés és a mélyinterjúk alapján történik.

A közösségben szerzett felkészültségeket elsősorban a mélyinterjúk során igyekeztem feltárni. 


\subsection{A főbb következtetések}

\section{Intézmények}

A vallás intézménye tekintetében a kutatásból az derült ki, hogy ugyan a megkérdezettek jellemzően nem tartják vallásnak a buddhizmust - sokkal inkább életfilozófiának, pszichológiának, egy olyan támpontnak vagy rendszernek, amely segít az életben - bizonyos (a William James-féle, a személyes élményt középpontba helyező) értelemben egy-két kivétellel tekinthetők vallásosnak vagy vallásos érzülettel rendelkezőnek (ami azonban egy általánosító és objektiváló meghatározás az esetükben). Jól alkalmazható terminus az autonóm vallásosság vagy a maga módján vallásosság, illetve akár a spirituális érdeklődés/útkeresés is.

A nyelv intézménye kapcsán a mélyinterjúkból az a kép bontakozott ki, hogy a megkérdezettek érzékelik a nyelv jelentette korlátokat (a buddhizmus szövegeinek eredeti nyelve, a tanító anyanyelve, a tanítások nyelve és a tolmácsolás miatti többszörös közvetítésből fakadó újraértelmezések megléte világos számukra), ez azonban nem lehetetleníti el a megértést. Ennek oka egyrészt az, hogy bár úgy vélik, valamilyen keleti nyelv ismeretével a buddhista szövegek, kifejezések újabb jelentésrétegei tárulhatnának fel számukra, de a személyes életükben való alkalmazáshoz elégséges az a tudás, amelyet a nyugati buddhizmusból magyarul, illetve angolul nyerhetnek. A másik ok pedig annak érzése, hogy az átadások nem csupán a szavak szintjén történnek meg.

A tudomány intézményének buddhizmussal kapcsolatos tárgyalása arra mutatott rá, hogy a két terület más vallásokhoz mérten könnyebb összeegyeztethetősége jelentős vonzerőt jelent a közösség tagjai számára.

\section{Színterek}

Az elvonulás funkciója a kutatás eredményei szerint (azon kívül, hogy az elvonuláson való részvétel a feltétele a közösségben való tagságnak) a kiszakadás a mindennapi élet forgatagából, a befelé figyelés, az elme lecsendesítése, az empátia erősítése, az 
önfejlesztés, a „jelenben levés”. Az elvonuláson való részvételt motiválhatja a kíváncsiság, a nehéz élethelyzetre való megoldáskeresés, a rekreáció igénye és a közösségben való gyakorlás (illetve a régebbi tagoknál a közösség más tagjaival való találkozás) lehetősége is. A közösség meglétét mindenki fontosnak tartja, abban azonban eltérések mutatkoznak, ki mennyire igényli a közösség támogatását a saját gyakorlásához.

A szakrális térben zajló szertartásokkal és rítusokkal való kapcsolat ambivalens, de a résztvevők jellemzően szeretik vagy elfogadják őket - azzal a kitétellel, hogy nem feltétlenül a szakrális jellegüket élik meg (bár arra is vannak példák), hanem inkább az érzelmi oldalukat, az emberi életben és közösségekben betöltött szerepüket hangsúlyozzák.

\section{Ágensek}

A közösség szerepével és jelentőségével kapcsolatban az derült ki, hogy a közösségben való tagságot sokféleképpen élik meg a megkérdezettek. A részvétel nagy vonalakban leírható a „mag” és a „holdudvar” fogalmaival, azonban ezek között nem éles a választóvonal. Az arról alkotott vélemény, hogy a közösség mennyire funkcionál kollektív ágensként, összefügg egyrészt az egyéni szerepvállalás és az elkötelezettség szintjével, másrészt a közösséggel kapcsolatos elvárásokkal is. Összességében a közösség meglehetősen rugalmasan kezeli a tagságot, ami egyrészt ronthatja a kohéziót, másrészt azonban könnyebbé teszi a bekapcsolódást. A tanító fontos szerepet tölt be a közösség életében, sokan kötődnek hozzá bizonyos szinten, de általában azt gondolják, a közösségnek önmagában is meg kell állnia. Az azonban egyértelműen bebizonyosodott, hogy a közösség elvonulásain a tanító személye nagy vonzerőt jelent, a résztvevők hiteles embernek tartják, és szívesen tanulnak tőle. A közösség összetételéből következően a tanító pszichológiai irányultsága kifejezetten előnyként jelenik meg. 


\section{Problémamegoldás}

A kutatásból az is kiderült, hogy a buddhista tanításból, a közösségben és kifejezetten az elvonulásokon a résztvevők olyan felkészültségeket szereznek, amelyek érzékelhetően segítik őket a problémamegoldásban. Ez igaz mind a magánéletre, mind a munkavégzésre és a munkahelyi kapcsolatokra. A buddhista tanítások leginkább úgy határozzák meg a mindennapi életvitelt, hogy az általuk képviselt elvek és attitűdök fokozatosan beépülnek a gondolkodásba, és belső késztetésként segítik a döntéseket bizonyos élethelyzetekben. A megkérdezettek arról számoltak be, hogy olyan felkészültségeket szereztek a buddhizmus révén, amelyek jelentősen befolyásolták és befolyásolják az emberi kapcsolataikat: jobban bele tudják magukat élni mások helyzetébe, ezáltal toleránsabbak, empatikusabbak, megértőbbek lettek. Saját magukat illetően pedig: nagyobb önismeretre tettek szert, könnyebben megbirkóznak a nehéz helyzetekkel, és jobban kezelik a konfliktusokat. Mivel a buddhizmust nem vallásként élik meg, nem jelent számukra gondot a más vallásokkal való esetleges összeegyeztetés sem. Emellett csak kevés konfliktussal szembesülnek a „buddhistaságuk” miatt, alapvetően azért, mert nem akarják másokra ráerőszakolni a saját nézeteiket.

A hipotéziseket a kutatás igazolta. 


\section{A kommunikáció intézményei}

\subsection{Kommunikáció és kultúra}

A kommunikáció fogalma szűkebben és tágabban is érthető: szorítkozhat csupán az egyes individuumok közötti verbális és egyéb interakciókra, üzenetközvetítésre, vagy továbbmehetünk, és belefoglalhatjuk a társadalom különböző formái és intézményei közötti kommunikációt. Emellett kitérhetünk akár speciálisan az egyes médiumok által közvetített információkra, de tekinthetjük a kommunikációt mint a különböző kultúrák közötti érintkezések módját, ha azokat a helyzeteket és folyamatokat vizsgáljuk, „amelyeknek során a különböző kulturális kódokkal, készségekkel és képességekkel rendelkező emberek egymással kommunikálnak, illetve együttműködnek" (Niedermüller [1999], p. 96.). E kultúrák között számos az emberi élet alapvető jellegzetességeiből, a gondolkodás természetéből fakadó hasonlóság van, egyáltalán, „a kultúra univerzális sajátossága az emberi társadalomnak”, azonban elméleti dilemmát jelent, hogy mindeközben „az emberi kultúrák mindenekelőtt a közöttük lévő különbségek alapján ragadhatók meg" (Niedermüller [1999], p. 98.).

Ezek a különbségek eltérő cselekvésekben manifesztálódnak, amelyek mögött eltérő kulturális tudás, fogalmi és szabályrendszer húzódik meg, magyarázattal szolgálva egyrészt a világ mibenlétét illetően, másrészt vezérfonalat nyújtva a mindennapokban való cselekvéshez. A kulturális antropológia/etnológia ${ }^{5}$ éppen ezért klasszikusan a fordítás eszközéhez nyúl - értve ezalatt a nyelvi fordítást és a

\footnotetext{
${ }^{5}$ A tudományterület megnevezésével kapcsolatban szükség van némi tisztázásra. A kulturális antropológia elnevezés Franz Boas német származású amerikai antropológushoz köthető, akit az amerikai antropológia atyjának is neveznek, és a kulturális antropológia ekképpen elsősorban az antropológia amerikai iskoláját jelöli. Franciaországban az etnológia, a briteknél pedig a szociálantropológia megnevezést használják erre a tudományágra. Az etnográfia, vagyis néprajz per definitionem az Európán belüli kutatásokkal foglalkozik, az etnológia pedig az Európán kívüli világgal, elsősorban az ún. „primitív”, természeti népekkel. Magyarországon a néprajz körébe tartoztak az ilyen jellegű kutatások, az amerikai típusú kulturális antropológia pedig egy meglehetősen fiatal tudományág, amelyet Boglár Lajos honosított meg munkatársaival 1990-ben az ELTE bölcsészkarán belül. Ez a kulturális antropológia már nem korlátozódik az etnográfia címszó alatt értendő kutatási sémákra (lásd Kézdi Nagy [2008] p. 11.). (A kulturális antropológia emellett megkülönböztetendő a fizikai antropológiától, amely az ember testi tulajdonságaival foglalkozik.) A dolgozatban tehát e fogalmak ennek figyelembevételével értelmezendők, azzal a megjegyzéssel, hogy az önmagában álló „antropológia” kifejezés mindig a kulturális antropológiára utal.
} 
kultúra „lefordítását” egyaránt. Malinowski úgy fogalmazta ezt meg, hogy az idegen kultúra tanulása az idegen nyelv elsajátításához hasonlítható, és nemcsak az idegen szavakat, hanem az idegen viszonyokat is le kell fordítani a hazai olvasóközönség számára. Sir Edward Evans-Pritchard pedig az antropológia fő problémáját az idegen kultúrák kifejezéseivel kapcsolatos szemantikai nehézségben látta, amelyek túltesznek a nyelvi fordítás okozta problémákon. Az antropológus feladata ekként az idegen kultúra nyelvének megtanulása mellett az, hogy megtanuljon annak koncepciói mentén gondolkodni és az értékei szerint érezni, majd a tapasztaltakat a saját kultúrája, illetve tudománya koncepcióiban, kategóriáiban és fogalmaiban fogalmazza meg. Tehát tulajdonképpen egyik kultúráról a másikra fordít. (N. Kovács [2004], pp. 6-7.) Arra, hogy ez a megközelítés helyes-e, később még visszatérek, előbb azonban szükség van néhány fogalom - elsőként a kultúra-meghatározására.

\subsubsection{A kultúra definíciója}

A kultúra definíciójára, alkotóelemeire nézve számos elméletet találunk, ezek közül csak néhány említésére van itt mód. Anthony Giddens szerint - aki hangsúlyozza, hogy a kultúra fogalma az egyik leggyakrabban használt terminus a szociológiában - a „kultúra a csoport tagjai által megőrzött értékekből, az általuk követett normákból és a létrehozott anyagi javakból áll. Az értékek absztrakt eszmények, míg a normák konkrét elvek vagy szabályok, melyek követését az adott csoport valamennyi tagjától elvárják" (Giddens [2003], p. 61.).

A kulturális antropológia legtöbb meghatározása - és Tim Ingold hangsúlyozza, hogy az antropológiai tankönyvek mind a mai napig ezt tekintik a tudományuk tárgya eredeti és meg nem haladott meghatározásának - Edward Tylor 1871-es definíciójára vezethető vissza. E szerint a „Kultúra vagy Civilizáció6, tágabban vett etnográfiai értelemben az a komplex egész, amely magában foglalja a tudást, a hitet, a művészetet, az erkölcsöt, a törvényt, a szokást és minden más képességet és sajátosságot, amelyre az ember a társadalom tagjaként szert tesz".

\footnotetext{
${ }^{6}$ Tylor itt a Kultúra terminust a Civilizáció szinonimájaként használja (kizárólag nagybetűvel és egyes számban), és nem egy állapotot ért rajta, hanem inkább azt a folyamatot, amelynek során az emberi közösségek a gyermeki tudatlanságtól a racionális felvilágosodás felé haladnak (Tylor meg volt győződve a társadalmi haladás elkerülhetetlenségéről). A Tylor utáni meghatározásokban ez az elem már ritkán jelenik csak meg. (Ingold [2004], p. 49.)
} 
(Ingold [2004], p.48.) Tulajdonképpen erre épül Jan Assmann több mint egy évszázaddal későbbi meghatározása is, amelyet az utóbbi évek egyik legnagyobb hatású kultúraelméleti munkájában, A kulturális emlékezet - Írás, emlékezés és politikai identitás a korai magaskultúrákban című könyvében írt le. Eszerint a kultúra nem más, mint egy olyan identitásbiztosító tudáskomplexum, amely szimbolikus formákban (rítusokban, mítoszokban, táncokban, tájegységekben, szent szövegekben stb.) tárgyiasul. A kultúra és a társadalom alapstruktúrák, az emberi mivolt redukálhatatlan alapfeltételei. (Assmann [2004], pp. 89., 132.)

Végül pedig mindenképpen meg kell említenünk a Clifford Geertz által adott definíciót is. Geertz miután kivesézte, hogy egyetlen rövid írásban ${ }^{7}$ is 11 különféle meghatározás született a kultúra fogalmáról, egy olyan, Max Weberre visszautaló, szemiotikai jellegű kultúrafogalom mellett száll síkra, amely szerint „az ember a jelentések maga szőtte hálójában függő állat”, a kultúra pedig ez a háló. A kultúra elemzését emiatt „nem törvénykereső kísérleti tudománynak, hanem a jelentés nyomába szegődő értelmező tudománynak" tartja. (Geertz [1994b], pp. 195-6.)

Mindezek a meghatározások számos olyan fogalmat említenek, amelyek e dolgozatban is szerepet kapnak: érték, norma, identitás, jelentés, gondolkodás, érzés, hit, viselkedés, rítus, szimbólum stb. A dolgozat ugyanakkor nem egy kultúraelméleti munka, hanem egy olyan, más kapcsolódó tudományterületekről is merítő írás, amely egy magyarországi buddhista kisközösségben - antropológiaikommunikációs nézőpontból - végzett kutatómunka segítségével tesz meglátásokat a nyugati buddhizmushoz forduló emberek motivációival, attitűdjeivel, értékeivel,

\footnotetext{
${ }^{7}$ Az amerikai antropológus, Clyde Kluckhohn Mirror for Man címú írásáról van szó, amelyről Geertz azt gondolja, hogy még mindig az általános antropológiába való jobb bevezetések közé tartozik. Kluckhohn munkája 1947-ben jelent meg, Geertz pedig a Sứrú leírást, amelyben Kluckhohnra hivatkozik, 1973-ban írta, azóta tehát számos kulturális antropológiai mű született. Geertz az idézett helyen összeszedte, hogy Kluckhohn milyen kultúrameghatározásokat adott 27 oldalas írása különböző részein: 1 . valamely nép egész életmódja; 2. a társadalmi örökség, amelyet az egyén csoportjától kap; 3. a gondolkodás, érzés és hit módja; 4. a viselkedés elvont tartalma; 5. az antropológus által kialakított elmélet egy embercsoport tényleges viselkedésmódjáról; 6. a felhalmozott tudás tárháza; 7. ismételten felbukkanó problémákkal kapcsolatos standard tájékozódások sora; 8. tanult viselkedés; 9. a viselkedés normatív szabályozásának mechanizmusa; 10. a külső környezethez és a többi emberhez való alkalmazkodás technikái; 11. a történelem üledéke. Kluckhohn ezek mellett még olyan hasonlatokhoz is fordul, mint „térkép”, „szita” és „mátrix”. (Geertz [1994b], pp. 195-6.) Kluckhohn egyébként A. E. Kroeberrel együtt összesen 161 kultúradefiníciót gyűjtött össze Culture: a critical review of concepts and definitions című munkájában. (Ingold [2004], p. 48.)
} 
értelmezéseivel stb. kapcsolatban. Ekképpen a kultúrát olyan dolognak tekintem, amely meghatározza az ember gondolkodását a világról, a tetteit, az értékrendjét, a többi emberhez való viszonyát, a velük folytatott kommunikációját, tehát „Szellemi” és társadalmi lényként való működését egyaránt. Az ember a kultúrán keresztül sajátítja el azokat a fogalmakat, viselkedési mintákat és eszközöket, amelyekkel az adott társadalomban funkcionálni tud, és a kulturális tudása, felkészültségei révén állít elő jelentéseket. Éppen emiatt válik érdekessé, mihez kezd egy személy vagy közösség egy nagymértékben eltérő kultúrából érkező nézetrendszerrel, mennyire képes annak fogalmait megérteni, illetve hogyan tud új jelentéseket létrehozni, az értékeit kulturálisan adaptálni és a mindennapi életébe beilleszteni. E kérdések megválaszolásához a kultúra-nyelv-gondolkodás viszonyát a későbbiekben még tárgyalni fogom.

\subsubsection{Kultúraközi kommunikáció}

Mielőtt továbbmennénk, a fejezet egyik nyitó gondolatához visszakanyarodva („de tekinthetjük a kommunikációt mint a különböző kultúrák közötti érintkezések módját, ha azokat a helyzeteket és folyamatokat vizsgáljuk, »amelyeknek során a különböző kulturális kódokkal, készségekkel és képességekkel rendelkező emberek egymással kommunikálnak, illetve együttműködnek «") szükséges egy kicsit jobban kifejteni, miért érdemes egyáltalán behozni a kultúraközi kommunikáció szempontjait.

A dolgozat azt tárgyalja, mi történik olyankor, amikor a zsidó-keresztény alapokon nyugvó magyar kultúrában megszerzett tudás, felkészültségek, kialakított jelentések birtokában lévő emberek egy „egzotikus” tan felé fordulnak, és azt választják - mint látni fogjuk, eltérő mértékben - életük vezérfonalául, illetve azt hívják segítségül mindennapi problémáik megoldásához. E találkozás már önmagában is tekinthető interkulturálisnak, mivel felmerül, mennyiben érthetők meg az ázsiai eredetű buddhista szövegek jelentései magyarul (és magyarok számára angolul, lásd később), hogyan módosulnak ezek a jelentések az eltérő kulturális kódok, tudáskészlet miatt, képesek-e a buddhista rítusok hozzájárulni a csoportidentitáshoz, valamint $\mathrm{mi}$ a helyzet a transzcendenssel való 
kapcsolatfelvétellel, tekintve hogy a közösség vallási szertartásai is többnyelvűek. Mindezek kifejtésére a dolgozatban sor kerül.

Emellett egy ennél jóval konkrétabban a kultúraközi kommunikáció tárgyába vágó jellegzetessége is van a vizsgált a közösségnek: a közösség magyar, a szellemi vezetője azonban egy holland buddhista tanító, aki angol nyelven tart elvonulásokat a közösség számára, ahol jelen van egy tolmács is. A helyzetet tovább bonyolítja, hogy a tanító mestere, akinek a tanítása szellemében a vizsgált közösség is működik, egy vietnami származású, Franciaországban élő, ott angol és francia nyelven tanításokat adó zen mester. A dolgozathoz végzett kutatás nagyrészt terepmunkával zajlott, és mint Niedermüller írja,

a „kultúraközi kommunikáció fogalmát a kulturális antropológián belül legalább három különböző, de egymással összefüggő szempontból lehet értelmezni. Egyrészt tekinthetjük az emberek közötti kommunikáció egy sajátos formájának, amelynek során különböző kultúrákhoz tartozó emberek kommunikálnak egymással. Másrészt jelölheti egyes társadalomtudományi diszciplínák konkrét kutatási tárgyát, amely az előbb említett jelenséget valamilyen szempontból - pl. japánok és amerikaiak kommunikációja, viselkedése üzleti tárgyalások során - vizsgálja. Végül pedig úgy is értelmezhetjük ezt a kategóriát, mint amely az empirikus kultúrakutatás (e kifejezéssel azokra a különböző európai országokban különböző elnevezésekkel - etnológia, néprajz, antropológia stb. - jelölt diszciplínákra utalok, amelyeknek közös metodológiai sajátossága az empirikus jellegű terepmunka), továbbá mindenekelőtt a kulturális antropológia egyik lényegi és konstitutív perspektíváját jelöli. Köztudott ugyanis, hogy a kulturális antropológia talán legalapvetőbb - elméleti és metodológiai - megkülönböztető jegye a terepmunka, amelynek során az antropológus a kutatása tárgyát jelentő kultúrát ott, azon a helyen és abban a környezetben tanulmányozza, vizsgálja, ahol az a kultúra kialakult és működik, azaz az antropológiai kutatás elsődleges terepe maga a vizsgálat tárgyát jelentő kultúra (Bernard 1989). Mivel ez a kultúra - különösen a klasszikus antropológiai kutatások esetében - mindig egy másik, idegen kultúra volt, az antropológiai megismerés eredendően és szükségszerűen a különböző kultúrák közötti különböző érintkezések eredményeként jön létre. Másként fogalmazva: nincs antropológiai megismerés kultúraközi kommunikáció nélkül (Kimball-Watson eds. 1972)." (Niedermüller [1999], p. 96.)

A jelen kutatás annyiban nem felel meg a Niedermüller által említett kulturális antropológiai perspektívának, hogy egy olyan buddhista közösséget vizsgál, amely nem egy idegen kultúrában jött létre (bár később látni fogjuk, hogy ez ennél bonyolultabb) - de maga az elsajátított kultúra idegen, a közeg bizonyos értelemben multikulturális, és éppen ezek a megfontolások képezik a vizsgálat tárgyát. 
A kultúra, kommunikáció és kultúraközi kommunikáció után térjünk rá egy másik fontos fogalomra, a vallásra.

\subsection{Vallás és társadalom}

\subsubsection{A vallás fogalmi tárgyalásának lehatárolása}

Az alábbiakban a kultúra fogalmának fenti leírásához hasonlóan röviden bemutatok néhány elképzelést a vallás mibenlétével kapcsolatban. Azt hangsúlyozni szeretném, hogy mivel a jelen dolgozat egy társadalomtudományi munka, a vallást alapvetően mint az emberi társadalmak és kultúra szerves részét, az emberi kommunikáció egyik intézményét tekinti, és a vallás fogalmával kapcsolatban elsősorban a vallástudomány, nem pedig a teológia vagy különféle vallási tekintélyek által adott meghatározásokat veszi figyelembe. Emellett a későbbiekben az a kérdés is fel fog merülni, hogy a buddhizmus a vallási megközelítésen kívül még hogyan értelmezhető. (Például ki fog derülni, hogy a vizsgált közösség tagjainak véleménye megoszlik abban a kérdésben, hogy a buddhizmus számukra vallás-e.) Ugyanakkor a dolgozatban teret adok olyan fenomenológiai nézőpontoknak is, mint Thomas Luckmanné és Gerardus van der Leeuwé, valamint a vallás olyan kitágított értelmezéseinek, amelyek a „maga módján való vallásosság” kategóriájához kapcsolódnak. Úgy gondolom, hogy a dolgozat által tárgyalt kérdések számos nézőpontból megközelíthetők, és a különféle elméletek mind hozzájárulhatnak a megértéshez, illetve eltérő mértékben alkalmazhatók egy-egy fogalom értelmezéséhez vagy egy-egy jelenség leírásához. Végső soron pedig a dolgozat be fogja mutatni, hogy a tárgyalt (vallási) közösség tagjainak élményeit, közösségben szerzett és a mindennapi életben felhasznált felkészültségeit, kommunikációját nagymértékben meghatározza a tudományos „szocializációjuk” is.

\subsubsection{A történelem-/kultúraalapú értelmezések}

Ha a vallás klasszikus szociológiai megközelítéseire vagyunk kíváncsiak, elsősorban Émile Durkheim és Max Weber nevét érdemes megemlítenünk. Durkheim $A$ vallási élet elemi formái című vallásszociológiai-etnológiai alapmunkájában arra hívja fel a 
figyelmet, hogy az írott történelem minden korszakából számos vallási tárgyú feljegyzéssel rendelkezünk, sőt, az azt megelőző korszakokból is maradtak ránk olyan emlékek, amelyek arra utalnak, hogy az ember vallásos „természete” már igen korán megnyilvánult. Azt hangsúlyozza, hogy a primitív ember számára a vallásos magyarázatok jelentették a világ legközvetlenebb elképzelési és megértési módját, elméje nem csak kétségbeesésében fordult ezekhez valamiféle ultima ratióként. Az általa a természeti erők befolyásolására alkalmazott rítusok nem irracionálisabbak, mint a mai, hasonló célú technikai eljárások. ${ }^{8}$ (Durkheim [2004], p. 35.) Durkheim nem ért egyet sem azokkal, akik a vallást a misztérium felől, sem azokkal, akik az istenség gondolata mentén kívánják meghatározni. A misztérium ${ }^{9}$ gondolata ugyanis nem eredendő, és csak kevés vallásban van jelen. ${ }^{10}$ Ugyanígy „vannak nagy vallások, amelyekből az istenek és szellemek gondolata hiányzik, vagy legalábbis csak másodlagos, halvány szerepet játszik bennük. Ilyen a buddhizmus”, amely - írja Burnoufra hivatkozva - „a brahmanizmussal szemben isten nélküli morál és

\footnotetext{
${ }^{8}$ Erről beszél egyébként Mircea Eliade vallástörténész is, amikor azt mondja, hogy a „kultúra legarchaikusabb szintjein emberként élni vallásos cselekedet volt, hiszen a táplálkozásnak, a szexuális életnek és a munkának szentségi értéke van. Másként szólva, embernek lenni - vagy inkább azzá válni - azt jelenti: »vallásosnak« lenni." (Eliade [1998], p. 7.) Illetve egy másik helyen, $A$ szent és a profán címü munkában: „Az archaikus társadalmak embere arra törekedett, hogy a szentben vagy a megszentelt tárgyak közelségében éljen. Érthető ez a törekvés, mert a "primitív«, valamint az összes premodern társadalom számára a szent egyet jelentett az erővel és végső soron a valósággal. A szent: valami, ami léttel telített. A szent erő egyszerre jelent valóságot, örökkévalóságot és hatóerőt." (Eliade [2014], pp. 9-10.)

${ }_{9}^{9} \mathrm{Pl}$. Otto beszél a misztériumról (mysterium tremendum). Az erős vallásos érzelmi megrendültség legmélyebb rétegét szemügyre véve (amennyiben az több, mint az üdvösségbe vetett hit, bizalom vagy szeretet) azt találjuk, hogy az „szinte őrjítő erővel tudja megindítani és betölteni a lelkünket”, és ha „beleérzéssel szemléljük az embereket a vallásosság heves kitöréseiben és hangulati megnyilvánulásaiban, szertartások és kultuszok ünnepélyességében és emelkedett hangulatában", akkor „a dolog kifejezésére csak egyvalami kínálkozik: a mysterium tremendum, a rettentő titok érzete. A misztérium fogalmilag azt jelenti, hogy „ami rejtve van, ami nem nyilvánvaló, amit nem fogunk fel és nem értünk meg, ami nem mindennapi és nem meghitt", de ezzel nem mondunk semmit a minőségéről. „Pozitív jellegét tisztán az érzéseinkben éljük át.” Otto az érzelmi dimenziót, a vallási élmény személyes megélését hangsúlyozza, amit a numinózus (a latin numen, vagyis istenség szóból) kifejezéssel ad vissza; a numinózus „irracionális, vagyis fogalmakban nem fejthető ki”, és azt mondja, hogy ez az érzés minden vallás alapja. (Otto [2001], p. 22.) Eliade írja Ottóról, hogy „nem isten és a vallás fogalmával foglalkozott, hanem a vallásos tapasztalás különböző formáit kívánta elemezni. Ottót pszichológiai éleslátása és kettős - teológiai és vallástörténészi - előképzettsége tette rá képessé, hogy e tapasztalás tartalmát és sajátos vonásait kibogozza. A racionális és spekulatív elemet mellőzve, a vallásnak elsősorban az értelem számára nem hozzáférhető oldalával foglalkozott." (Eliade [2014], p. 7.)

${ }^{10}$ Ernst Troeltsch és Weber azonban a miszticizmust a kereszténység autentikus formájának tartja.
} 
Természet nélküli ateizmus”, vagy pedig ahogy Oldenberg nevezi, „isten nélküli11 vallás". (Durkheim [2004], pp.38-9.) Durkheim a szent és a profán megkülönbözetéséből, valamint az egyház létezésének szükségességéből kiindulva végül a következőképpen határozza meg a vallást: „A vallás szent, vagyis elkülönített és tiltott dolgokra vonatkozó hiedelmek és gyakorlatok összefüggő rendszere, amely a híveket az egyháznak nevezett morális közösségbe egyesíti." (Durkheim [2004], pp. 44-53.)

Max Weber - a vallásszociológia egyik alapító atyja - munkáiban a vallást mint olyan társadalmi jelenséget tekinti, amely szorosan kapcsolódik az adott közösség gazdasági-társadalmi berendezkedéséhez. Fejtegetései célja elsősorban nem az egyes vallások puszta leírása, sokkal inkább a kapcsolódó gazdasági etikák feltárása. Így vallásszociológiai írásai egy olyan keretbe illeszkednek, amely a Nyugat modern gazdasági etikájának sajátosságait igyekszik megragadni. A keleti és nyugati világ közötti fejlődésbeli különbségeket a vallásra vezeti vissza, és a leíráshoz „a vallások pszichológiai és pragmatikai összefüggéseiben gyökerező gyakorlati cselekvési indítékokat" (Weber [2007], p. 52.) veszi szemügyre. Nem a vallás lényegével kíván foglalkozni, hanem „egy meghatározott fajtájú közösségi cselekvés feltételeivel és hatásaival", amihez az egyének szubjektív élményeire, elképzeléseire, céljaira - a cselekvés értelmére - kell hagyatkoznia. (Weber [2005], p. 9.)

Az elemzésbe a világvallásokat vonja be. Világvalláson azokat a vallási vagy vallásilag meghatározott rendszereket érti, amelyek a hívők különösen nagy tömegeit voltak képesek mozgósítani: a konfuciánus, a hinduista, a buddhista, a keresztény és az iszlám vallási etikáról beszél. Ezekhez hozzáveszi még a zsidó vallást, mivel lényegi történelmi előfeltételeket tartalmaz, és történelmi jelentősége is nagy. E vallások jellegzetességeinek vizsgálatához pedig azon társadalmi rétegek életvitelének irányadó elemeit tekinti, „amelyek az illető vallás gyakorlati etikáját a legmeghatározóbban befolyásolták" ${ }^{12}$

(Weber

[2007], pp. 51-2.)

\footnotetext{
${ }^{11}$ A buddhizmus e vélt „istennélküliségére” később még visszatérek.

12 Leírása szerint a konfucianizmus egy irodalmilag képzett, világian racionalista javadalmazotti réteg rendi etikája. A régebbi hinduizmus hordozója az irodalmilag képzett személyek örökletes kasztja volt. A buddhizmust otthontalanul vándorló, szigorúan kontemplatív, a világot elutasító kolduló szerzetesek terjesztették. Az iszlám a kezdeti korszakában a világhódító harcosok, a zsidóság a száműzetéstől kezdve egy polgári párianép vallása volt, a középkorban pedig utóbbi egy sajátosan rá jellemző, irodalmilag-rituálisan iskolázott értelmiségi réteg vezetése alá került. A kereszténység
} 
Weber ezekben a fejtegetésekben tipológiát alkot, amely sok helyen vitatható, bár maga is hangsúlyozza, hogy a későbbi kutatók majd bizonyára kiigazítják megállapításait, amelyek már csak azért is pontatlanok lehetnek, mivel munkája során fordításokra volt kénytelen támaszkodni. Másrészt azt is elismeri, hogy az általa vázoltak szükségképpen leegyszerűsítőek, sematikusak, ezzel szemben a vallások mind történeti képződmények, a „túlnyomó többségük több típus kombinációja, vagy átmeneti állapot több típus között”. (Weber [2007], p. 84.)

Heinrich von Stietencron indológus a vallástudomány sajátosságaként említi, „hogy tárgyát, a történeti vallásokat, megkísérli a lehető legpontosabban vizsgálni, ám nem képes pontosan meghatározni azt, hogy mi a vallás (egyes számban). Ezért általános és viszonylag nyitott értelemben használja a »vallás« kifejezést gyưjtőfogalom gyanánt számtalan, részben igen különböző, de történetileg megragadható jelenség jelölésére." Stietencron úgy tekinti a vallást, mint amely „a világnak és a valóságnak az emberek valamely csoportja által elfogadott értelmezési modellje, e modellhez rendelt értékekkel, normákkal és az ezekből következő emberi magatartás-, észlelés- és gondolkodásformákkal”. Ezt a nyitott meghatározást azonban még ki kell egészíteni valamilyen olyan kritériummal, amelynek alapján megkülönböztethetők egymástól a világ vallási és nem vallási értelmezési modelljei. A vallásinak nevezett értelmezési modellek célja eszerint egyrészt az értékek-normák tételezése, érvényesítése vagy éppen megváltoztatása, valamint a társadalom stabilizálása a társadalmi feszültségek levezetése vagy semlegesítése révén; másrészt kapcsolatok kiépítése, viszonyulások felállítása és értelemalapítás olyan területeken, amelyek messzemenően kivonják magukat a direkt kapcsolatfelvétel és a közvetlen értelemmegtapasztalás lehetősége alól. Ez utóbbi aspektus a döntő, mert ez különbözteti meg a vallást más értelmezési rendszerektől. A kapcsolatfelvétel a Szembenlévő-Más-sal történik, és az, hogy ez

vándorló kézművessegédek tanításaként kezdte pályáját, és kezdettől fogva egészen sajátosan városi, mindenekelőtt polgári vallás volt, és maradt mindvégig. Azonban bármennyire is hatottak a gazdasági és politikai körülmények egy-egy vallási etikára, azok arculatukat elsősorban mindig vallási forrásokból nyerték. (Weber [2007], pp. 53-4.) Wolfgang Schluchter szerint Weber itt nem szociológiai, hanem kulturális értelemben beszél a rétegekről. (Hivatkozza: Banyár Magdolna: A vallástudomány lehetőségei és határai Max Weber vallásszociológiájának tükrében. Tattva, 2008. p. 74.) 
valamiféle transzcendens Isten vagy személytelen erő, már kulturálisan meghatározott, és a konkrét vallások körébe tartozik. ${ }^{13}$ (Máté-Tóth-Mezei [m.a.])

\subsubsection{Kortárs és kitágított értelmezések}

A vallás a tudomány fejlődésével sem tűnt el, egészen a modern korig „békében” megfért egymás mellett a kettő. A modern korban a társadalomtudományok ugyan hajlottak arra a nézetre, hogy „a vallás ellentétes a modernizációval, régmúlt és túlhaladott kultúrformákból él, és valójában olyan, a társadalmi fejlődésből kimaradó rétegekre támaszkodó jelenség, amelynek létjogosultságát a történelem lassan felszámolja" (Tomka [1996], p. 163.), azonban jelenleg úgy tűnik, a párhuzamos tudományos elméletek ellenére is tartja magát, sőt, bizonyos szinten újraéledésének lehetünk tanúi. A fenomenológiai iskolát képviselő Thomas Luckmann szerint bármennyire különbözik a modern társadalom emberének életmódja a más kultúrákban élő emberétől, élete alapvetően vallásos felépítése nem veszett el, azon a társadalmi és kulturális változások sem változtattak. „A valóság társadalmilag konstruált modelljeinek fő témái kétségtelenül megváltoztak, és a modern társadalomhoz vezető strukturális változások következtében átalakultak azok a tipikus minták is, amelyhez az egyén tudata igazodik, de maga az a modellalkotás, amely az egyént egy társadalmilag és történelmileg transzcendens valóságba állítja bele, vallásos processzus." (Luckmann [1996]) Szerinte a vallás alapvető funkciója abban áll, hogy egy természeti faj egyedeit egy történetileg kialakult társadalmi rend cselekvő tagjaivá alakítsa át. Luckmann ugyanakkor meglehetősen tágan értelmezi a vallást (beleértve például a celebek áhítatos tiszteletét is). De az alábbi szövegrész felhívja a figyelmet egy olyan aspektusra, amely lényeges a témánk szempontjából: „Nem könnyű szabadulni attól az etnocentrikus előfeltevéstől, hogy csak az vallás, ami a mi társadalmunkban a vallás tapasztalatának megfelel. De ha az emberiség tevékenykedésének és szenvedéseinek történetét tekintjük át, társadalmi adottságok roppant sokaságát

\footnotetext{
${ }^{13}$ A meghatározás a Magyar Vallástudományi Társaság gondozásában készülő Vallástudományi kézikönyv (szerk.: Máté-Tóth András-Mezei Balázs) egy fejezetéből származik, amely itt érhető el: filozofia-miskolc.net/wp-content/uploads/2011/11/Stietencron.pdf
} 
láthatjuk, amelyek azt az alapvető vallási funkciót szolgálták, hogy az emberi lényeket beillesszék egy történelmi társadalmi rendbe." (Luckmann [1996])

Luckmann egyébként a 60-as évekre datálható szociológiai szekularizációs tézist „modern mítosznak” nevezte. A szekularizációs tézis szerint a modern társadalmakban csökken az egyházhoz köthető vallásosság, a vallás privatizálódásának lehetünk tanúi. Az elmélet kritikusai főleg azzal érvelnek, hogy az elmélet a nyugat-európai fejlődési úthoz kötött. Habermas azt írja ezzel kapcsolatban, hogy

a „szekularizációs tézist, bár az európai jóléti társadalmak fejlődése ezt megerősíteni látszik, a szociológus szakmai nyilvánosságban már több mint két évtizede vitatják. Az Európa-centrikusan beszűkült látószög nem teljesen alaptalan kritikájának nyomán immár a »szekularizációs elmélet végét« emlegetik. Az Egyesült Államok, amely változatlanul eleven hitközösségeivel és a vallásilag elkötelezett és aktív állampolgárok változatlan részarányával mégiscsak a modernizálás élvonalát képezi, hosszú ideig a szekularizációs trend alóli nagy kivételnek számított. A más kultúrákra és világvallásokra való globálisan szélesebb kitekintésből tanulva ma már inkább ez tűnik a normális alapesetnek. Ebből a revideált nézőpontból az európai fejlődés, amely okcidentális racionalizmusával modellként kellett volna hogy szolgáljon a világ többi részének, ma inkább kezd a voltaképpeni különútnak tűnni." (Habermas [2008])

Maga Peter Berger, az elmélet egykori híve is módosította álláspontját, és már inkább az euroszekularizáció kifejezés használatát javasolja. Már nem az Egyesült Államokat tekinti kivételnek, mint korábban, mivel a világ egészének vallásosságával kapcsolatos adatok azt mutatják, hogy Nyugat- és Közép-Európa a világ legerősebben szekularizált része. Ugyanakkor óvatosságra int, mivel

„míg egyértelmű különbségeket találunk az Egyesült Államok és Európa között, azt sem szabad elfelejtenünk, hogy a vallási kérdésekben végzett felmérések adatai mindig gyanúsak. Az amerikaiak hajlamosak eltúlozni vallásosságukat a felmérés kérdéseire adott válaszaikban, míg az európaiak lehet, hogy épp világi beállítódásukat hangsúlyozzák jobban a kelleténél. Illusztrációképpen említem, hogy pár évvel ezelőtt néhány ügybuzgó szociológus összevetette a templomba járást firtató kérdésekre adott válaszokat egy adott helyen a templom parkolójában parkoló autók számával, és azt vették észre, hogy jóval kevesebb parkoló autóra bukkantak annál, mint amennyire a válaszok alapján számítani lehetett. És fordítva, amikor az Estonia nevü komp elsüllyedt a Balti-tengeren néhány évvel ezelőtt, és a balesetben számtalan svéd halt meg, az emlékezetükre tartott szertartásokon dugig voltak a templomok Svédországban - egy olyan országban, ahol a legmagasabbak a világi gondolkodás mutatói." (Berger [2006], p. 29.) 
A vallásosság meghatározása és mérése tehát igen problematikus. A két amerikai vallásszociológus, Rodney Stark és Charles Y. Glock Piety: The Nature of Religious Commitment című könyvét például egy Erasmus-idézettel kezdi, amely szerint „minden meghatározás veszélyes”. Stark és Glock figyelmeztet, hogy amikor valakit vallásosnak mondunk, az alatt számos különböző dolgot érthetünk: egyházi tagságot, vallási doktrínákban való hitet, etikus életvitelt, istentiszteleten való részvételt - és számos más tevékenységet, életszemléletet és körülményt is tekinthetünk vallási elkötelezettségnek.

Világos, hogy amikor a „vallásos” kifejezéshez különféle jelentéseket társítunk, akkor nem egyszerű szinonimákról, hanem egyetlen jelenség aspektusairól van szó. A legtöbb ember, aki valakiről tudja azt, hogy aktív tagja valamely egyháznak, azt is várja, hogy az illető szilárdan hisz az adott doktrínákban, és gyakorolja is hitét a mindennapi életében. Az egyházi tagságot, a hitet és az etikus tetteket általánosságban a vallásosnak levés összetevőinek tartják. Ugyanakkor az, hogy valaki vallásos a fentiek egyikének értelmében, nem garantálja, hogy a többiben is az - van, aki erős hittel és kötődéssel bír, de mégis nehezen tekinthető etikus embernek. Az tehát, hogy valakit vallásosnak tekintünk-e vagy sem, komplex probléma. Ezenkívül arra is felhívják a figyelmet, hogy a vallásos elkötelezettség definiálásánál és operacionalizálásánál meg kell határozni azokat a különböző dolgokat, amelyeket a kifejezés jelenthet, és azokat a különböző módokat, ahogyan az emberek vallásosak lehetnek.

Az egyes vallásokban meglévő konkrét hiteken és gyakorlatokon túl minden vallásban erős konszenzus van azon általános módra vonatkozóan, amelyben a vallásosságnak meg kellene nyilvánulnia. E tekintetben öt dimenzió különböztethető meg, és a világ különböző vallásai számos és sokszínű vallási előírásainak mindegyike besorolható ezek valamelyikébe. Ezek: a vallásos hit, gyakorlat, élmény, ismeret és a következmények. ${ }^{14}$ Az első négy dimenzió egy

${ }^{14}$ Hit: ez a dimenzió olyan elvárásokat tartalmaz, minthogy a vallásos személy rendelkezzen bizonyos teológiai szemlélettel, és elismerje a vallása tanainak igazságait. Minden vallás rendelkezik a hitek bizonyos készletével, amelyek elfogadása elvárt a hívőktől. Ugyanakkor e hitek tartalma és hatóköre nemcsak a vallások között, de gyakran ugyanazon vallási tradíción belül is változik.

Gyakorlat: olyan dolgokat foglal magában, mint az imádság és áhítat, tehát amiket az emberek a vallási elkötelezettségük végrehajtásaként tesznek. Ezek két fontos osztályba sorolhatók: rituálé és áhítat. Míg a rituálé erősen formalizált és jellemzően nyilvános, addig minden ismert vallás értékeli 
komplett referenciakeretet biztosít a vallásos elkötelezettség értékeléséhez. Ezek ugyan nem teljesen függetlenek egymástól, de az egyértelmű, hogy vallásosnak lenni az egyik dimenzió szerint nem szükségszerűen jár együtt egy másik dimenzió szerinti vallásossággal. Ezenkívül bár a vallásoknak mindre szükségük van, nem egyenlő fontosságot tulajdonítanak nekik, ugyanakkor minden vallásnál a teológia vagy a vallásos hit/vélekedés (belief) a hit (faith) magja. ${ }^{15}$ A vallás csak a valóság végső természetéről, a természetfeletti természetéről és szándékairól, valamint a vallás más aspektusairól alkotott hitek bizonyos készletén belül lehet koherens. (Stark-Glock [1968], pp. 11-6.)

William James egy időben jóval korábbi (1902-es) munkájában, a The Varieties Of Religious Experience. A Study In Human Nature című előadás-gyűjteményben pszichológiai szempontból tekint a vallásra, és így elsősorban a személyes

a személyes imádságot és kontemplációt, amelyek viszonylag spontánok, informálisak és jellemzően privátak.

Élmény: ez a dimenzió azt a tényt veszi figyelembe, hogy minden vallásnak vannak bizonyos várakozásai (még ha ezek pontatlanul is vannak megfogalmazva) azzal kapcsolatban, hogy a megfelelően vallásos személy el fog érni bizonyos közvetlen, szubjektív ismeretet a végső valóságról (tehát lesz bizonyos érzése a természetfelettivel való kapcsolatról). Ez a dimenzió azokkal a vallási élményekkel, érzésekkel, észlelésekkel és érzelmekkel foglalkozik, amelyeket egy személy megtapasztal vagy egy vallási csoport (vagy társadalom) meghatároz, és amely bizonyos kommunikációt von magával az isteni lényeggel (Istennel, a végső valósággal, a transzcendens autoritással). Abban vannak eltérések, mely élményeket tartják megfelelőnek az egyes vallási tradíciók és intézmények, és a vallások eltérnek abban is, hogy milyen fokon bátorítanak bármilyen típusú vallási találkozást. Mindazonáltal minden vallás tulajdonít legalább minimális értéket a szubjektív vallási élmény bizonyos változatosságának mint az egyéni vallásosság jelének.

Ismeret: ez a dimenzió utal arra az elvárásra, hogy a vallásos személyek rendelkeznek a hitük alapvető tanaival, rítusaival, irataival és hagyományaival kapcsolatos információk bizonyos minimumával. Az ismeret és a hit dimenzió egyértelműen összekapcsolódik, mivel a hit ismerete szükséges előfeltétele az elfogadásának. Ugyanakkor a hit nem az ismeretből következik, mint ahogy nem minden vallási ismeret van hatással a hitre. Sőt, egy személy rendelkezhet hittel anélkül is, hogy valóban értené azt, tehát a hit alapulhat nagyon kevés ismereten is.

Következmények: a vallási elkötelezettség ezen dimenziója eltér a másik négytől. Ez a vallásos hit, gyakorlat, élmény és ismeret hatásait azonosítja a személy mindennapi életében. A „munka” fogalma jelenik meg itt teológiai értelemben. Bár a vallások sok mindent előírnak abból, hogy a híveik mit gondoljanak és tegyenek a mindennapi életükben, nem teljesen egyértelmű, hogy a vallási következmények milyen mértékben részei a vallásos elkötelezettségnek, vagy mennyiben csak következnek belölük. (Stark-Glock [1968], pp. 14-6.)

${ }^{15}$ Inkább plauzibilis egy tudatlan hívőt vallásosnak hívni, mint egy jól informált szkeptikust. Vagy az a hívő, akinek nem volt még vallási élménye, hívható vallásosnak, de azt a személyt, akinek vannak vallási élményei, de nincsenek vallási hitei, inkább hívják pszichotikusnak. A hívő, aki bűnt követ el, amikor megpróbálja a hitét megélni a mindennapi életében, még vallásosnak minősül, de az etikus ateista nem. Tehát a hit dimenziója különösen szükséges, de gyakran nem elégséges aspektusa a vallási elkötelezettségnek. 
aspektusok, a vallásos érzések és indítékok, nem pedig az intézmények érdeklik. Ennek megfelelően nem kívánja pontosan definiálni a vallás tartalmát. A vallások sokféleségéből inkább az következik, hogy ezt egyfajta gyűjtőfogalomként érdemes használni, nem pedig valamilyen egyedi alapelvként vagy lényegként. $\mathrm{Az}$ elméletalkotó elme egyébként is hajlamos túlzottan leegyszerűsíteni az anyagát, és ez a gyökere a filozófiákra és a vallásokra is jellemző mindenféle abszolutizmusnak és egyoldalú dogmatizmusnak. Ha nem követjük ezt a módszert, akkor valószínűleg nem találjuk meg a vallás „lényegét”, de találunk számos olyan jellemzőt, amelyek egyaránt fontosak a vallásban.

Egy példa erre, hogy sok könyv tárgyalja úgy a „vallásos érzést”, mintha az egyfajta mentális entitás lenne, amelyet a szerzők különféle módokon (pl. a függőség érzése, a félelem származéka, a végtelen érzése stb.) megpróbálnak meghatározni. De ha gyűjtőnévként kezeljük arra a sokféle érzelemre vonatkoztatva, amit a vallásos tárgyak kiválthatnak, akkor csak valamiféle pszichológiai sajátosságot találunk, ami lehet vallásos félelem, szeretet, öröm stb. Ezek azonban csupán az ember természetes érzelmei, amelyek ebben az esetben vallási tárgyra irányulnak. Tehát olyan tudatállapotról van szó, amely érzésből, valamint bizonyos típusú tárgyból tevődik össze. Így nincs szükség arra, hogy feltételezzük a létezését valamilyen egyszerű, absztrakt vallásos érzelemnek, amely elkülönült elemi mentális vonzalomként kivétel nélkül minden vallási tapasztalatban jelen van.

James tehát az intézményes vallásosság helyett a személyes élményt helyezi a középpontba, és azt javasolja, hogy vallásnak az egyén magányosan megélt érzéseit, tetteit és tapasztalatait tekintsük, amennyiben azok megragadhatók úgy, mint amelyek kapcsolatban állnak az általa isteninek tekintett dologgal. (James [2009], pp.7., 24-7.) Ez a megközelítés hasznosnak tűnik a dolgozat tárgya szempontjából, ezért a későbbiekben még visszatérek rá.

\subsection{A vallás kommunikációs nézőpontból}

Az eddigiekben a vallást vallástudományi (szociológiai, etnológiai, vallástörténeti) és pszichológiai perspektívából közelítettem meg, a kommunikációról pedig leginkább a kultúra vonatkozásában esett szó. Az alábbi fejezetben a kommunikációnak a jelentések előállításában és közössé tételében betöltött 
funkciójáról lesz szó, amely értelemben a vallást is tekinthetjük egyfajta kommunikációként.

A kommunikációelmélet többfajta megközelítést kínál a vallás jelenségével kapcsolatban: említhetjük egyrészt az egyházi kommunikációt mint diszciplínát, amely az egyháznak a társadalom bizonyos csoportjaival (és önmagával) történő kommunikációját vizsgálja. Ez a terület tárgyunk szempontjából nem releváns. Másrészt kibontakozóban van az úgynevezett szakrális kommunikációs irány, amelyről Korpics Márta és P. Szilczl Dóra azt írja: „nem állíthatjuk, hogy a kommunikációelmélet segítségével bármit is mondhatnánk magáról a transzcendensről, igazolhatnánk létezését a vele való kommunikáció megléte alapján. Amit le tudunk írni, az nem más, mint a transzcendenst tételező vélekedések kommunikációja, ahogy az az egyén számára a közösségbe tartozás révén elérhető". ${ }^{16}$ (Korpics-P. Szilczl [2007], p. 17.) Mivel a szakrális kommunikáció egy fiatal iránya a kommunikációkutatásnak (a fogalom magyar nyelvű alkalmazásának kidolgozása Lovász Irén nevéhez köthető), különféle területekről merít: többek között a fenomenológiából, antropológiából, szociológiából, valamint a participációs elméletből is, ebből fakadóan bizonyos meglátásai tárgyunk szempontjából is használhatók.

Az általánosabb vallási kommunikáció terminussal jelzett terület kapcsán Máté-Tóth András (Tomka Miklósra hivatkozva) azt írja, hogy annak témaköre kimeríthetetlen, és „kutatása magába foglalja a vallási nyelv hermeneutikai és pszichológiai problémáit, a hit átadásának kérdéseit, a tömegkommunikáció megjelenéséből adódó új helyzet elemzését" is. (Máté-Tóth [2013], p.11.) Hangsúlyozza, hogy saját kutatása során önkényesen párosított bizonyos kommunikációelméleti modellt bizonyos valláselméleti modellekkel - más modellek is választhatóak lettek volna. De az rögzíthető, hogy „a vallás és a kommunikáció alapvető emberi és társadalmi dimenzió, amely vizsgálható a vallástudomány és a kommunikációtudomány közös erőterében". (Máté-Tóth [2013], pp.13-4.) Máté-Tóth utal a fentebb tárgyalt William Jamesre is: „James

\footnotetext{
${ }^{16}$ Ezek a vélekedések az egyes vallásokban eltérőek, kulturálisan determináltak, és a transzcendens „azáltal válik felfoghatóvá, hogy rendelkezésre állnak - közösségenként különböző módon - olyan szimbolizációs eszközök, melyek révén a transzcendensről úgy gondolkodhatunk, mintha kapcsolatba kerülhetnénk vele, és erről másoknak is be tudunk számolni”. (Korpics-P. Szilczl [2007], p. 19.)
} 
elkötelezettsége a téma iránt vitán felül áll. Troeltschhöz vagy másokhoz hasonlóan elemzéseivel és téziseivel azt akarta bizonyítani, hogy a vallás az adott modernizálódó világban minden más, csak nem lényegtelen, perifériális jelenség. Későbbi utódjaihoz hasonlóan - gondolhatunk Luckmannra, részben Bergerre s még inkább Luhmannra - ő is funkcionális vallásfogalommal dolgozott, amely révén a nem-intézményes vallásosságot jobban meg lehetett ragadni." (Máté-Tóth [2013], pp.18-9.) (A funkcionális vallásfogalmon Máté-Tóth egy a kutatás céljára létrehozott fogalmat ért.) A dolgozat szempontjából a Jameshez köthető személyes vallásosság koncepciója tűnik a leginkább alkalmazhatónak, ez lesz tehát a kiválasztott modell. A kommunikációelmélet tekintetében pedig a már említett participációs modellt használom fel.

\subsection{Kapcsolódás a participációs elmélethez}

A kommunikáció participációs elméletét kiindulópontul használva Horányi szerint abban bízhatunk, hogy „segítségével a kommunikáció valamennyi jelenségtípusa egységes keretben válik leírhatóvá”. Egy olyan elméleti keretről van itt szó, amelyben a kommunikáció fogalma a participáció fogalmára épül, és amelyben „az egymással kommunikációban álló ágenseknek felkészültségekben (tudásokban, hiedelmekben, szokásokban és más ezekhez hasonlókban) való kölcsönös részesedéséről érdemes gondolkodnunk, amelyek a sikeres (emberi) problémamegoldás szükséges feltételeként mutatkoznak meg”. (Horányi [2006], p. 14.)

A participációs elmélettel kapcsolatban olyan fogalmak rövid tisztázására lesz szükség, mint az intézmény, színtér, ágens, felkészültség, szignifikáció és probléma. Ezek - különösebb magyarázat nélkül - már előkerültek az eddigiekben is. A bevezetőben szó volt arról, hogy részben azért a kommunikáció participációs elmélete adja a keretet, mert több olyan (társadalmi) intézményt - nyelv, kultúra, tudomány, vallás - is vizsgál, amelyek relevánsak a téma szempontjából. Adolgozatban tárgyalt buddhista közösség programjait tekinthetjük a kommunikációs színtérnek, a közösség mint olyan és a tagjai által birtokolt és elérhetővé tett felkészültségek pedig leírhatók a terepmunka és az interjúk alapján. 
Ebben a keretben a következő általános kérdéseket lehet megfogalmazni: Milyen problémák megoldására szolgál a közösség, és a tagok (ágensek) miért éppen az adott közösséget választják? Hogyan keletkeznek új szignifikációk a közösségi élet, szertartások, más kommunikációs aktusok során? Megjelennek-e, és ha igen, milyen konfliktusok az ágens életének közösségen kívüli színterein? Milyen konfliktusok adódnak a közösségen belül? Milyen megoldásokat talál az ágens ezekre a felkészültségei révén? A következőkben az említett fogalmak participációs elméletben használt rövid meghatározása következik.

\subsubsection{Meghatározások}

A kommunikáció információelméleti megközelítésében kommunikáció minden, amiben információ továbbítása történik, függetlenül attól, hogy az információ milyen jelekben vagy a jelek milyen rendszerében, kódjában fejeződik ki. A személyközi kommunikációban a kommunikáló felek biológiai kódokkal és biológiailag meghatározott kódlehetőségekkel rendelkeznek. Ezen belül és ezek mellett azonban az alkalmazott kód döntő része szociális, szociokulturális térben és szabályok között, szociális viszonylatban megy végbe. (Buda [1986], pp. 16-22.)

A participációs elmélet a 'kód' helyett az intézmény kifejezés használatát részesíti előnyben. Ennek oka, hogy úgy tűnik, „a kommunikáció ágensei sok olyan dologgal élnek, mint a kódok, amelyek azonban szokásosan nem számítanak kódnak. Szerepük azonban a jelentésadásban és a rendteremtésben pontosan olyan, mint a kódoké: sajátos felkészültségeket (tudásokat és egyebeket) kínálnak az ágensek világot értelmező és rendező késztetéseihez." (Horányi [2006], p. 11.) Az intézmény ebben a - társadalomtudományban jellemzően használatos - értelemben a társadalomban kialakult rendszert, formát, szokást jelenti, tehát „intézménynek nevezzük a társadalomban érvényesülő, az egyének cselekedeteit irányító vagy befolyásoló, illetőleg behatároló szabályokat, írott vagy íratlan törvényeket és ezek rendszereit, (...) az ezen szabályok betartását biztosító mechanizmusokat (szervezetek, társadalmi értékek, szankciók)”. (Pete-P. Szilczl [2006], p. 17.) Ebben az értelemben intézmény például a nyelv, amely nélkül nincs kommunikáció, de intézmény a vallás, a kultúra stb. is. 
A színtér olyan kontextus, szituáció, környezet, háttér, helyzet, amelyben a kommunikáció megtörténik. A kommunikáció sohasem önállóan, más társadalmi jelenség, összefüggés kizárásával van, hanem mindig valahol, valamikor és még más módon is beszövött a kommunikátor személyes és/vagy a társadalom intézményi valóságába. Ahhoz, hogy valamely kommunikáció beszövöttsége felderítettnek legyen tekinthető, a maga helyén kell vizsgálni, nem pedig kiszakítva abból (mint ahogy az gyakran megtörténik). (Horányi [2006], p. 11) A színtér nem magában áll, hanem mindig ágenshez kötött, és az ágens mindig színtérhez kapcsolódik. Az ágensek a megnyilvánulásaikban mutatkoznak meg ágensként. A színtér tehát az a hely, ahol az ágens ágensként megnyilvánul. A színtér elemzésénél figyelembe kell venni a térbeli és időbeli körülményeket, az esemény résztvevőinek számát, a résztvevők integráltságát (vagyis azt, hogy milyen módon tudnak egymásról, milyen mértékben vannak figyelemmel egymásra), valamint azt, hogy milyenek a színtéren lévők körülményekre vonatkozó ismeretei, előzetes tudásai, képességei, elvárásai összefoglalóan: felkészültségei. A különböző felkészültségtípusok különböző színtértípusokat eredményeznek. Színtérnek összefoglalóan tehát mindazokat a körülményeket nevezhetjük, amelyek valamely ágens számára meghatározzák egy adott esemény lehetséges interpretációit, vagyis azt, hogy az ágens milyenként ismeri fel mindazt, ami körülötte történik. (Domschitz-Hamp [2006], pp. 110-1)

A színterek osztályozásánál az elsődleges szempont az ágensek felkészültsége. A színtéren az ágens minden megnyilvánulása problémamegoldó megnyilvánulás is egyben. A „felkészültségek alapján az azonos (vagy közel azonos) felkészültségekkel rendelkező ágensek egyfajta közösséget alkotnak, továbbá a problémaszíntéren megjelenhetnek más, nem azonos felkészültségekkel rendelkező ágensek is, amelyeknek az előbbiekkel részben közös, részben kölcsönös felkészültségeik vannak". A nemcsak eredendő felkészültséggel rendelkező ágensek (akiknek válaszai adott körülmények mellett automatikusnak tekinthetők) hatékonyabban tudnak problémát megoldani. (Domschitz-Hamp [2006], pp. 133-4)

A participációs elméletben a probléma a jelenlegi és a vágyott (elérni kívánt) állapot különbségeként határozódik meg, így a problémamegoldás az egyik állapotból a másikba való átmenetet jelenti. Ha létezik a problémának megoldása, akkor ez azt jelenti, hogy a jelenlegi állapotból van átmenet a vágyottba. A problémamegoldás, vagyis az átmenet a felkészültség(ek) segítségével történik 
meg. A világ vágyott állapota a jelenlegi állapotából bizonyos intézmény(ek) által meghatározott módo(ko)n érhető el. (Pete-P. Szilczl [2006], p. 42.)

Kommunikációnak azt a nyilvánosságot nevezhetjük, amelyben a korábban csak valamely ágens számára elérhető felkészültség más ágens(ek) számára is elérhető (vagy éppen elérhetővé válik): a kommunikáció elérhetővé tesz olyan felkészültségeket, amelyek ezt megelőzően nem voltak az ágens felkészültségei. Ha az ágens legalább részben kommunikáció által jut hozzá felkészültségéhez, akkor az ágens kommunikációra való felkészültségét (így a szerepre, a kommunikációs rendszerre és a világismeretre vonatkozó felkészültségeket) és ennek változásait, például fejlődését is sajátvilága részének kell tekinteni. (Horányi-Szabó [2006], pp. 234-5.)

A szignifikáció a megértés egyik módja, amely lényegét tekintve konceptualizáció. A szignifikációs eljárás tulajdonképpen egy kategorizáció, amely elválaszthatatlan az interpretáció során mozgósított koncepciók meglététől. Ahhoz, hogy valami tárgya lehessen az ágens észlelésének, az ágensnek rendelkeznie kell bizonyos koncepciókkal, pontosabban szignifikációk rendszerével, amelybe az adott észlelet beilleszthető (vagy beilleszthetőnek gondolt). Ezekhez a koncepciókhoz az ágens a nyelven és más intézményeken keresztül fér hozzá. Akkor képes valamit észlelni, ha rendelkezik azokkal az eljárásokkal, amelyek segítségével számára a dolgok „valamiként” jelennek meg. Az ágens részéről ennek megfelelően a szignifikáció két dolgot jelent: egyrészt ennek vagy annak, ilyennek vagy olyannak tartani valamit; másrészt rendelkezni azzal a konstitutív szabállyal, amelynek alapján ennek vagy annak, ilyennek vagy olyannak tartunk valamit. A szignifikáns az, amit az ágens a szignifikátum, „jelentéseként” ért. Az ágens számára maga a szignifikátum csak a szignifikánson keresztül elérhető. (Pete-P. Szilczl [2006], pp. 44-6.)

A dolgozat fejezeteiben tehát ezeket a fogalmakat a megadott definícióknak megfelelően használom, és a kommunikációt ennek megfelelően értelmezem.

\subsection{A buddhizmus Nyugaton: sokszínú kapcsolatok}

Ebben a fejezetben öt összefüggő témát érintek. Az első a nyugati buddhizmus történetének és jellegzetességeinek rövid áttekintése, külön kitérve egy speciális nyugati alakulatra, a társadalmilag elkötelezett buddhizmusra. A második részben a 
vallások közötti párbeszédet hirdető, Keleten elmélyült tudást szerző keresztény szerzők gondolatai kapnak helyet. A harmadik téma a nyugati tudományos gondolkodás (a pszichológia és az idegtudomány) buddhizmushoz való kapcsolódása és annak kritikája. Negyedikként a nyugatiak Kelet felé fordulását értelmező Easternization thesist és annak kritikáját mutatom be. Az ötödik részben pedig a magyarországi buddhizmus áttekintése szerepel.

E témák együttes tárgyalásának több oka is van. Egyrészt a vizsgált közösség megértéséhez szükséges némi betekintést nyerni az átfogóbb keretbe, vagyis a nyugati buddhizmusba, majd, szűkítve azt, a magyarországi buddhizmusba mindezt olyan értelmezési lehetőségekkel kiegészítve, amelyek adalékul szolgálnak a buddhizmus iránt érdeklődők, az elvonulásokon részt vevők motivációinak, vallási identitásának, praxisának stb. feltárásához. Másrészt a buddhizmus és tudomány kapcsolatát tárgyaló fejezet azért került be, mert a pszichológia és az idegtudomány buddhista elvek és gyakorlatok iránti érdeklődése nyilvánvaló módon kötődik a buddhizmus nyugati megjelenéséhez. A pszichológia tudományára egyértelműen hatottak és hatnak a tudattal és az érzékeléssel kapcsolatos buddhista nézetek Jungot itt mindenképpen meg kell említenünk, de a jelenlegi különféle terápiás gyakorlatokban is szívesen alkalmazzák a buddhizmus meglátásait, módszereit a terapeuták. Ez pedig nemcsak az analitikus terápiákra igaz, hanem pl. a meditációt sokan használják a stressz, a szorongás, a depresszió kezelésére, a konfliktuskezelési és problémamegoldási készségek javítására. Az idegtudomány pedig mostanság elkezdte tudományos eszközökkel kutatni a meditációt, annak pszichológiai és fiziológiai hatásait. Egyértelmű tehát, hogy itt a témánk szempontjából releváns területekről van szó, hiszen ezek a kutatási érdeklődések és pszichológiai alkalmazások nemcsak az emberi agy és elme megértését célozzák, hanem ennek révén az életminőség javítását, a mindennapi problémamegoldást is.

Egy további ok a vizsgált közösség összetétele, vagyis hogy a tagok számottevő része pszichológusként, terapeutaként dolgozik, illetve más segítő munkát végez. Ez magára a tanítóra, sőt, a tolmácsra is igaz: Jan Boswijk tanításaiban a buddhista tan és a pszichológia szervesen kapcsolódva, egymást kiegészítve jelenik meg, a tolmács pedig a fordítás során maga is használja pszichológiai tudását (lásd később az ezzel kapcsolatos fejezetet). Az interjúkból ráadásul kiderült, hogy a közösségben szerzett ezzel kapcsolatos felkészültségeket a megkérdezettek tudatosan beépítik a 
pszichológiai/terápiás munkájukba (nemcsak az ügyfeleikkel végzett munkába, hanem a kollégáikkal való kapcsolataikba is). A közösség tehát erősen pszichológiai irányultságú, és a problémamegoldáshoz használt felkészültségek komoly részét teszik ki az ide sorolható ismeretek. Ennek megfelelően a téma az interjúk során is újra és újra előkerült, így a mélyebb megértés érdekében mindenképpen érdemes kitérni rá.

\subsubsection{A nyugati buddhizmus}

A nyugati buddhizmus történetének kiváló összefoglaló - de alapvetően a zen, a tibeti és a vipasszana tradícióra fókuszáló - munkája James William Coleman amerikai szociológus The New Buddhism: The Western Transformation of an Ancient Tradition című könyve. Coleman remek áttekintést nyújt a nyugati buddhizmus három hullámban való megjelenéséről, jellegzetességeiről az ázsiai irányzatokkal összevetve, valamint azokról a társadalmi okokról és egyéni motivációkról, amelyek a buddhista tan felé vezérelhetnek embereket. Colemané mellett természetesen más informatív munkák is elérhetők a tárgyban, amelyek inkább egy-egy buddhista irányzatra vagy a nyugati buddhizmussal kapcsolatos bizonyos résztémákra fókuszálnak (és megjegyzendő, hogy az amerikai buddhizmusról jóval több munka áll rendelkezésre, mint az európairól). Ilyen például Peter Bishopnak a tibeti buddhizmus nyugati elképzeléséről írt könyve, valamint Alioune Koné a zen európai elterjedéséről szóló írása. A jelen fejezet ezekből a munkákból merít.

A nyugati buddhizmus megértéséhez fontos áttekinteni annak történetét, ami - mivel másfél évszázaddal ezelőtt a buddhizmus Nyugaton gyakorlatilag ismeretlen volt ${ }^{17}$ - ugyan nem kimerítően, de viszonylag röviden is megtehető bizonyos lényeges pontok kiemelésével. Erre azért is szükség van, mert ez az áttekintés közelebb vihet bennünket a magyarországi buddhizmus és a vizsgált közösség megértéséhez is: a megkérdezettek egy része kifejezetten hangsúlyozta, hogy a

17 A megbízhatóbb források szerint a japán zen buddhizmus már a XVII-XVIII. században megérkezett Európába, ugyanakkor a XIX. század második fele előtt nem volt meg a koherens buddhista vallás elképzelése Nyugaton. A korai forrásokkal kapcsolatban érdemes megemlíteni, hogy Xavéri Szent Ferenc jezsuita szerzetes leveleiben fellelhető bizonyos tudás a buddhista praxissal kapcsolatban, később pedig Engelbert Kaempfer német természettudós 1727-ben publikált Japán története című mûvében ad pontos leírást a zen ülő meditációról (zazen). (Koné [2006], p. 6.) 
nyugati buddhizmushoz tud kapcsolódni18, mások pedig - függetlenül attól, hogy magukat buddhistának tartják-e - egyértelműen besorolhatók a buddhizmus felé forduló, Coleman által említett értelmiségiek közé. Most tehát egy történeti áttekintés és a nyugati buddhizmus fő sajátosságainak leírása következik.

A buddhizmussal találkozó első nyugatiak keresztény misszionáriusok (és utazók) voltak, őket azonban nem kifejezetten a megértés szándéka vezette, és csak egy újabb „pogány” vallásként hivatkoztak rá. Valódi érdeklődés eleinte az értelmiség körében indult meg, és a XIX. században kezdtek komolyabban is foglalkozni a buddhista szövegekkel. ${ }^{19}$ A század közepén az európai tudósok elkezdtek más képet festeni róla. ${ }^{20}$ Ebben a buddhizmus mint negatív vallás jelent meg, amely elutasítja Isten elképzelését és az individuális lélek üdvözülését, és a személyiség teljes megsemmisítését tekinti a legnagyobb jónak. Ez az új látásmód akkor született meg, amikor az amerikai protestantizmus intellektuális krízisbe került, és számos kihívással kellett szembenéznie a tudományos szkepticizmus, valamint az ipari forradalom és az urbanizáció okozta társadalmi változások miatt. A darwini evolúcióelmélet megingatta a keresztény hit kozmológiai alapjait, az összehasonlító vallástudomány és a bibliakritikai kutatások pedig erodálták a kereszténység azon igényét, hogy az egyetlen igaz vallásként tüntesse fel magát. Ekkor az elégedetlen értelmiségiek egy része elkezdte a buddhizmusban a kereszténység alternatíváját látni, mivel kompatibilisebb a tudományos

\footnotetext{
18 Például ebben az interjúban is erről számolt be a megkérdezett: „Mi itt vagyunk Nyugaton, és nem hiába vagyunk itt Nyugaton, és nem hiába van ez, hogy most egyre több ember [érdeklődik a buddhizmus iránt]. Nyilván nem azt a mélységét kapjuk meg a buddhizmusnak, amit egy ott élő. Voltam Keleten, tehát volt tapasztalatom egy pici, már úgy beleláttam, és ők annyira másban vannak, más a társadalom és mások a mindennapjaik, ott minden pillanatban sokakat áthat a vallásosság. Én meg tudom élni, hogy itt Nyugaton nem annyira vallás. Ott sok a gyakorlat meg a szertartás. (...) Ez egy lebutított dolog szerintem, amit mi kapunk, hiszen a nyelv azért nagyon sajátos, és bizonyos szavakat biztos nem tudnak úgy fordítani, ahogy az eredetiben van, az is már egy értelmezés, és ha egy tanítótól hallod, az is az ő személyén keresztül [megy]." (Viktória)

${ }^{19}$ Bár a buddhista gondolkodás korai nyugati értelmezése pontatlan és felületes volt, olyan nagy hatást gyakorló európai filozófus is beépítette a munkáiba, mint Schopenhauer, valamint olyan amerikai szerzők, mint Emerson, Thoreau és Whitman. (Coleman [2002], p. 55.)

${ }^{20}$ Az első szimpatizáló munka Sir Edwin Arnold 1879-ben megjelenő The Light of Asia című eposza volt Buddha életéről. Ez a Jézus és Buddha élete között fellelhető párhuzamokat hangsúlyozta, és félmillió-egymillió közötti példányszámban kelt el. (Coleman [2002], p. 56.)
} 
világnézettel, és toleránsabb a különféle véleményekkel és álláspontokkal szemben. ${ }^{21}$ (Coleman [2002], pp. 55-6.)

Észak-Amerikában az első jelentősebb buddhista esemény az 1893-ban Chicagóban megrendezett World Congress of Religion gyűlés ${ }^{22}$ volt. Ekkor már számos olyan ázsiai bevándorló élt Észak-Amerikában, akik magukkal vittek különféle népszerű buddhista irányzatokat. Nekik azonban nem sok közük volt ahhoz a kulturális elithez, amelynek tagjai az ilyen jellegű találkozókon részt vettek. Eddig a napig tehát a fő választóvonal a nyugati buddhizmusban az ázsiai bevándorlók „etnikai alapú buddhizmusa” és a nyugatiak által felvett „új buddhizmus" volt. Az első buddhista irányzat, amely utat talált az amerikai

\begin{abstract}
${ }^{21}$ Másrészt az okkultizmus új hulláma iránti megnövekedett érdeklődés is végigsöpört a Nyugaton, és míg egyesek a nyugati okkultista hagyományból merítettek, mások az egzotikus Kelet felé fordultak inspirációért. Ennek a kornak az egyik legfontosabb fejleménye a teozófia megszületése. A teozófiát eredetileg Egyiptom és India okkult forrásai inspirálták, de aztán egyre inkább a buddhizmus felé fordult - olyan kortárs vallást látott benne, amely a leghúbben adja vissza az ősi bölcsességet. Ugyan a teozófusok nyugati okkultizmusból és keleti miszticizmusból álló keveréke nagyon távol áll a fôsodrú buddhizmustól, mégis fontos szerepet játszott a keleti elképzelések - és különösen a buddhizmus - elterjesztésében. (Coleman [2002], pp. 56-7.)
\end{abstract}

Nagyon jól tükrözi ezeket a motivációkat az alábbi interjúrészlet is: „Én egyrészt mint harcművész kezdtem el ezzel foglalkozni, a 'dó' igazi jelentését próbáltam megérteni, így közelítettem a délkeletázsiai harcművészeteken keresztül magához a buddhizmushoz. Egyrészt elkezdtem vonzódni a buddhizmushoz a magam kis meglehetösen szekuláris világnézetével, egy tudományos, földhözragadt elmével. Ez szerintem az egyik legfontosabb érv e mellett a közösség [a Szelíd Mosoly] mellett. Mint harcmúvészt nagyon érdekelt a 'dó', de az életvitelembe nem igazán fértek bele a vallások a tudományos és szekuláris szemléletem miatt. Mindenkinek van spirituális igénye, talán valami vágy, valami olyan dolog, ami ott gyökerezhet, ahol a művészetek is gyökereznek. Az ember és a múvészet alkalmazása során egy óriási kérdőjel alakult ki bennem, egy nagyon nagy hiányérzet, tulajdonképpen az első igazi igényem a spirituális képbehelyezkedés igénye, mégpedig az ego és az individuum viszonya, hogy mi köze van az én személyiségemnek az egómhoz, és mit csinál. A mai tudásommal azt mondom, hogy akkor ráébredtem a manasz [elme/tudat] jelenlétére, és mint művész ezt próbáltam keresni. (...) $A$ múvészeten keresztül elkezdtem tibeti buddhizmussal foglalkozni, és egy idő után olyan belső energiákat, megéléseket sikerült kiszabadítani, amik szerintem az aktív drogfogyasztáshoz hasonlóak. És ahogy a művészetben egyre inkább ezt a betöltött ưrt próbáltam megtalálni, egyre furcsább területekre jutottam el, [például] az okkultizmushoz." (Zsolt)

22 A kongresszusra való meghívásként több mint 10 ezer levelet küldtek ki különféle vallási csoportoknak szerte a világon, aminek az eredménye a vallási vezetők példa nélküli gyűlése lett, ami megnyitotta az amerikai vallási élet kapuit a keleti vallások előtt. Ezen a gyűlésen vett részt Sōen Shaku is, aki (elsősorban csekély angoltudása miatt) itt még nem, de - főleg tanítványai révén később nagy hatást gyakorolt az amerikai buddhizmusra. Az ő tanítványa volt D. T. Suzuki, akit aztán Rick Fields, a buddhizmus történetének egyik kiemelkedő kutatója „az amerikai zen első pátriárkájaként" írt le. Ő valószínűleg többet tett a zen nyugati bevezetéséért, mint bárki más. Ellentmondásos figura volt, akinek az USA-ba érkezése előtt megvilágosodási élménye (satori) volt, de soha nem kapott hivatalos Dharma-átadást, és nem volt zen-tanító a hagyományos értelemben. Inkább egy értelmiségi és a leginkább antiintellektuális buddhista tradíció filozófusa volt. (Coleman [2002], p. 58.) 
közönséghez, a japán zen volt. A World Congress of Religion gyülésen felszólaló japán rinzai mester, Sōen Shaku nem vált igazán ismertté, diákja, D. T. Suzuki azonban igazi sztár lett. Ő volt az, aki bevezette a paradoxonokra épülő zen gondolkodást a nyugati értelmiségiek számára. ${ }^{23}$ (Coleman [2002], p. 7.)

Míg Amerika a szervezett buddhizmussal először a zen formájában találkozott, a korai brit buddhizmus a théravádából merített ${ }^{24}$. A britek legfontosabb théraváda szervezete a Maha Bodhi Society volt, amelyet Anagarika Dharmapala (a három évtizeddel korábbi amerikai gyúlésen nagy sikert aratott) Sri Lanka-i szerzetes alapított 1925-ben Angliában. Mint más országokban is, a buddhizmus itt is a magasan képzett emberek számára volt vonzó. Dharmapala mellett a brit buddhizmushoz leginkább a londoni büntető törvényszék képviselője, Travers Christmas Humpreys járult hozzá. ${ }^{25}$ (Coleman [2002], p. 61.) Őt sok más európaival együtt a XX. század első felében Suzuki karizmája és írásai inspirálták a théraváda buddhizmusról a zenre való váltásban. (Suzuki nyugati filozófia és pszichológia iránti érdeklődése lehetővé tette, hogy a zent szélesebb közönséggel is megismertesse.) 1951-ben azt írta Buddhism című munkájában, hogy „a zen a buddhizmus apoteózisa". (Koné [2006], pp. 6-7.)

Az utazás és a kommunikáció könnyebbé válásával, valamint a bevándorlás növekedésével a Kelet és a Nyugat közelebb került egymáshoz, az etnikai buddhizmus megszokottabbá vált Nyugaton, és alkalmazkodott az új környezethez. Miközben az „új buddhizmus” első hulláma még a kifinomult, magasan képzett emberek számára jelentett vonzerőt, a második - Tibetből érkező - hulláma ${ }^{26}$ már az átlagember igényeit kívánta kielégíteni. Az első tibeti tanítók az 1960-as években kerültek Nyugatra, de a következő évtizedig nem építettek ki intézményi jelenlétet.

\footnotetext{
${ }^{23} \mathrm{Az}$ 1950-es évekre a legtöbb művelt nyugati legalábbis hallott már a zen buddhizmusról, még ha továbbra is reménytelenül különösnek és egzotikusnak is tartották. Ekkoriban a beat generáció bohémjai a zent egy intellektuális talizmánnak, a bevett gondolkodásmód kihívójának tartották. (Coleman [2002], pp. 7-8.)

${ }^{24}$ Ennek oka, hogy a brit birodalom két olyan országot is kormányzott, amelyek a théraváda (theravāda, „az idősebbek útja”) tradíció legprominensebb képviselői: Sri Lankát és Burmát.

25 Ő ugyan inkább teozófiai beállítottságú volt, de mindeközben fáradhatatlan szervező, szónok és író. 1924-ben megalapította a Buddhist Lodge szervezetet, amely eredetileg a Teozófiai Társasághoz tartozott. Később a Buddhist Lodge-ot átnevezték Buddhist Societyvé, és a Maha Bodhi társaság mellett a brit buddhizmus egyik pillérévé vált. (Coleman [2002], p. 61.)

${ }^{26}$ A 60-as és 70-es évek ugyanakkor a „zen boom” időszaka is volt, amikor jelentős számú nyugati kezdte meg a buddhista gyakorlást. Bár a kezdeti lelkesedés lelohadt, egyre több zen központ alakult. (Koné [2006], p. 8.)
} 
A karizmatikus tibetiek ${ }^{27}$ kimeríthetetlennek tűnő forrása táplálta az érdeklődést, a tibeti buddhizmust pedig elsősorban a Dalai Láma szimbolizálta „együtt érző” jelenlétével és politikai jelentőségével. (Coleman [2002], pp. 7-8.)

A Tibettel és vallásával kapcsolatos nyugati reakció története azonban ennél sokkal régebbi és tágabb: felöleli az imperializmus, a pszichoterápia, a tudomány, az irodalom ${ }^{28}$, a teozófia és az alternatív vallások, a pszichedelikumok, a kalandtúrák, a felfedezés, a hegymászás és az ökomozgalmak vonatkozásait is. A tibeti buddhizmus tehát nem egy légüres térbe érkezett, hanem egy jól előkészített terepre: a Nyugat már 400 éve gyűjtötte a Tibettel kapcsolatos ismereteket. A tibeti buddhizmus iránti kortárs nyugati érdeklődés viszont már jelentős mértékben a fejlett és kifinomult vallásgyakorlásra fókuszál: a spirituális, okkult és parapszichológiai erő kifejlesztésére; filozófiai és pszichológiai meglátásainak mélységére és finomságaira; a meditáció és a jóga bonyolult részleteire; az istenek és félistenek óriási panteonjának bonyolult szimbolizmusára. (Bishop [1993], pp. 13-8.)

A harmadik hullám a vadzsrajána ${ }^{29}$ berobbanása volt az 1980-90-es években. A nyugati buddhizmusnak ez az az irányzata, amelyik a gyökereket tekintve a legrégebbre nyúlik vissza. A Nyugaton vipasszanaként ismert gyakorlási stílus a théraváda tradícióból ered, ami Ázsia déli részein volt uralkodó. A legtöbb tudós úgy tartja, hogy ez szorosabban kötődik Buddha eredeti tanításaihoz, mint bármelyik másik irányzat. Az egyik legfontosabb különbség a vipasszana és a többi új buddhista iskola között egy történelmi véletlennek tudható be. A zent és a tibeti buddhizmust ázsiai tanítók hozták el Nyugatra, a vipasszanát azonban olyan

\footnotetext{
27 Kulturálisan az extrovertált tibetiek harsány színeikkel, sokkarú isteneikkel, erotikus tartalmaikkal határozottan eltértek az illedelmes, egyszerű eleganciával öltöző, fekete-barna köpenyes japánoktól. A mértékletes japánokkal szemben a tibetiek nem haboztak kifejezni szenvedélyes érzelmeiket. Ezt a vonzerőt világítja meg a következő interjúrészlet is: „Sok olvasmányt próbáltam begyűjteni erről a vallásról, nyilván mert még vallásnak gondoltam, és eközben valahol a tibeti tradíció környékén kötöttem ki, mert megfogtak a gyönyörü rituálék, a gyönyörü monumentális, démonokkal telitüzdelt külsőségek, az ezotéria, ilyen titkos vágyak. Ezt gyönyörünek és rejtélyesnek találtam, és azt gondoltam, ez a csodaszép tradíció lesz az, ami igazán közel visz a dologhoz. De igazából mindig megakadtam a kalpáknál meg a reinkarnáció magyarázatánál, meg olyan dolgoknál, amik befogadhatatlanná tették nekem ezt mint vallást, mint bármelyik másik vallást." (Zsolt)

${ }^{28} \mathrm{Az}$ irodalmi művekben megjelenő Tibet-kép egyúttal a Nyugatot is tükrözi. Antonin Artaud (1940es évekbeli) Tibetje például kontrasztban áll a Nyugat spirituális szennyezettségével, szenvedésével, közömbösségével.

${ }^{29}$ (Vajrayāna) a mahájána buddhizmus egy tantrikus változata.
} 
nyugatiak, akik Thaiföldön vagy Burmában tanulmányozták azt. Ennek eredményeképpen a vipasszana szekulárisabb és nyugatibb, kisebb keleti kulturális csomaggal rendelkezik. Sok vipasszana-tanítóra gyakorolt hatást a nyugati pszichológiai gondolkodás és terápiás hagyomány. (Coleman [2002], pp. 8-9.)

Ugyanakkor ebben az időszakban felmerült az „európai zen” meghatározásának szükségessége is: bár a zen volt az egyik legvonzóbb buddhista tradíció a nyugatiak körében a XX. században, a jól dokumentált amerikaiakkal ellentétben az európai csoportok nem túl ismertek. Ezért 1993-ban egy stockholmi konferencián régóta gyakorlók és tanítók gyűltek össze annak érdekében, hogy meghatározzák, kialakulóban van-e egy sajátosan európai zen gyakorlat, egy „európai zen”. ${ }^{30}$ Az gyorsan kiderült, hogy nincsen egységes európai zen identitás. Nagyon sokféle zen átadás van, ezek azonban annyira különböznek a személyes és kulturális aspektusaikban, hogy eddig nem volt közös megnevezésük. Ez a sokféle iskola és alak, amelyeket Európában egyetlen gyưjtőnév, a zen foglal magában, fontos különbségeket alakított ki az „importált” hitekben és gyakorlatokban. (Koné [2006], p. 2.)

Ha a buddhizmus felé fordulás okait tekintjük, a fentebb felsoroltak (intellektuális érdeklődés, tudományos szkepticizmus, valamint az ipari forradalom és az urbanizáció okozta társadalmi változások) mellett nagy szerepet játszott benne az 50-es és 60-as években tetőző „amerikai álom”, vagyis a fogyasztói társadalom és a radikális individualizmus kombinációja, amely maró és instabil keveréknek bizonyult. A fogyasztás kultúrájának anyagi értékei bővelkedtek pszichológiai ellentmondásokban. Akik feljebb jutottak, elégedettek voltak, akik elbuktak, csüggedtek lettek. És ahogy egyre több amerikai ért el anyagi sikereket, gyakran kellett szembesülniük egy erős, de nehezen megfogható elégedetlenséggel. ${ }^{31}$ (Coleman [2002], p. 61.)

\footnotetext{
${ }^{30}$ A programot bevezető kérdések az alábbiak voltak: „Melyek az eredeti zen nélkülözhetetlen tulajdonságai, amelyek Európában, az európai körülmények között is léteznek? Milyen igények állnak fenn ma egy eredeti zen közvetítővel kapcsolatban? Milyen alakzatok és struktúrák felelnek meg legjobban a zen európai átadásának?" Az egyik résztvevő rámutatott, hogy korábban egyik kérdést sem tárgyalták még.

${ }^{31}$ Az első ilyen nemzedék a beat generáció volt, amely elutasította a hagyományos amerikai kultúrát, és az új perspektívákba a buddhizmus is bekerült. A buddhizmus iránti beat-érdeklődés kezdetét gyakran Suzuki egy az 50-es években a Columbián tartott előadássorozatához kötik, de mélyebb
} 
Ha a jelenlegi állapotot nézzük, Coleman szerint a nyugati buddhizmus már túl van a gyerekkorán, de még nem érte el a felnőttkort. Friss, innovatív és sokszínű irányzat, amely jól kezeli a tinédzserkori ügyetlenséget. A legtöbb serdülőhöz hasonlóan pedig könnyen azonosíthatók benne nemcsak azok a magok, amelyekből a karaktere kialakul, hanem a szülőktől való eltérések is. A buddhizmus a nyugati késő modernitás prizmáján megtörve jelenik meg, de egyértelműen hasonlít ázsiai őseihez - és még feltűnőbben Buddha több mint két évezredes eredeti tanításaihoz. Több nyilvánvaló hasonlóság is van köztük: hogy Buddha követői sem beleszülettek, hanem „spirituális éhségükből” maguk választották; hogy Buddha maga sem fektetett túl nagy hangsúlyt a rítusokra és a ceremóniákra - nem a hit, a helyes viselkedés vagy a rituális odaadás a legfőbb cél, hanem a megvilágosodás megtapasztalása; valamint mindkettőjükre jellemző az egalitarianizmus ${ }^{32}$. Mindezen hasonlóságok ellenére azonban az új nyugati buddhizmus nem tartozik azok közé a fundamentalista mozgalmak közé, amelyek a múltbeli „igazi buddhizmushoz" akarnak visszatérni. (Coleman [2002], pp. 217-8.)

Fontos különbség azonban, hogy a buddhista út a kolostorokból a mindennapi élet terepére helyeződött át. Az ókori Indiában és Ázsia legtöbb részén a buddhista mozgalom középpontja a kolostori élettel járó lemondás volt, az új buddhizmusban viszont a megszabadulásért folytatott küzdelem tere már nem a kolostor. Bár a nyugati buddhisták néhány hetes intenzív elvonulásokra visszavonulnak a „földi” tevékenységektől, és néhányan az év bizonyos időszakaiban beköltöznek valamilyen buddhista központba gyakorolni, a megvilágosodás most már valami olyasminek tűnik, ami a mindennapi élet szenvedésének és örömének sűrűjében realizálódik. (Coleman [2002], p. 219.)

gyökerei is vannak: a legnagyobb hatást gyakorló személyek - Ginsberg, Snyder, Kerouac (a „Beat Zen") - nem az előadóteremben, hanem a könyvtárban találkoztak a buddhizmussal (persze többek között Suzuki munkáival is). A zenben a spontaneitást és a szabadságot látták meg, és a zen egy olyan abszolút perspektívát kínált, ahonnan nézve a fogyasztói társadalom normái értelmetlennek, önkényesnek és nem valóságosnak tűntek. (Coleman [2002], p. 62.)

32 Azon történetek ellenére, miszerint Buddha hezitált a nők szanghába való beengedésével kapcsolatban, a maga idejében a buddhizmus radikálisan egalitárius volt. Buddha valóban beengedte a nőket a szanghába, és egyértelmü volt a megvilágosodásra való képességük tekintetében is. Emellett szembeszállt a társadalma merev kasztrendszerével, és minden társadalmi csoportból és rétegből bevett embereket. A nyugati buddhizmusban osztálybeli korlátozásokkal kapcsolatban sosem merült fel kérdés, és ez az irányzat óriási lépéseket tett a nők teljes részvételéért - tagokként és tanítókként egyaránt. Ezenkívül a különféle stigmatizált csoportok (pl. melegek, leszbikusok) számára is jóval nyitottabb, mint a hagyományos nyugati vallások. (Coleman [2002], p. 218.) 
A vallási betéréssel kapcsolatos motivációk éppolyan sokfélék, mint maguk az emberek. Általánosságban elmondható, hogy azok, akik valamilyen buddhista csoporthoz csatlakoznak, jellemzően másfajta vallási orientációval rendelkeznek, mint akik például Amerikában a mormon egyházhoz vagy egy fundamentalista keresztény csoporthoz csatlakoznak. Coleman szerint az utóbbiakat választók inkább keresnek valamilyen támogató társadalmi csoportot, amely megerősíti az általuk vallott értékeket, és olyan hitet, amely értelmet és célt ad az életüknek. A buddhisták orientációja azonban „misztikusabbként” írható le (a „misztikus” szóban benne van valamiféle másvilági tapasztalat keresése). A vallási spektrumnak a nyugati buddhizmus sokkal inkább a misztikus vége felé esik, mint a hagyományos nyugati vallások. Úgy is lehet mondani, hogy inkább befelé, a végső valóság közvetlen személyes megtapasztalására irányul, mintsem kifelé, a meglévő társadalmi rend világa felé. (Coleman [2002], p. 221.)

Koné az európai zennel kapcsolatban egy jóval profánabb irányultságra utal, amikor Thomas Tweedet idézi, aki rámutat, hogy a tudósok és a gyakorlók valamiféle normatív meghatározást tartanának jónak a tekintetben, hogy mi az európai buddhizmus, de ez módszertanilag problémás, mert nem fedné le a jelenségek összességét. Tweed azt javasolja, hogy az önmeghatározásokat a „buddhista tevékenységekben való részvétel” meghatározással kell helyettesíteni, mert az „éjjeliszekrény buddhisták”33 vagy szimpatizánsok is egyértelműen hozzátartoznak a nyugati képhez. (Koné [2006], p. 4.)

Az új buddhizmus bizonyos értelemben rokonítható a New Age mozgalmakkal: mindegyiket olyan nyugatiak választják, akik az „ortodox” valláson kívül szeretnék teljesíteni spirituális igényeiket. Szociológiai értelemben azonban a nyugati buddhizmus formalizáltabb szervezeti struktúrával rendelkezik, és hosszú múltra visszatekintő hagyománya korlátozó hatással van rá, ami nem igaz a New Age

33 Tweed szükségesnek tartja megkülönböztetni a szimpatizánsokat az „éjjeliszekrény buddhistáktól" (night-stand buddhists), mégpedig az elkötelezettség szintjének megfelelően. A szimpatizánsok olyan emberek, akik ugyan szimpatizálnak egy vallással, azonban nem fogadják el azt kizárólagosan vagy teljes mértékben. Nem definiálják magukat buddhistának. Ugyanakkor az otthonukat vagy a napi rutinjukat megfigyelve felfedezhető, hogy érdeklődnek a buddhizmus iránt, így pl. gyakorolják a zazent, olvasnak buddhista weboldalakat vagy könyveket, esetleg részt vesznek előadásokon, és buddhista tárgyakkal díszítik az otthonukat. Lehetnek más vallások követői. Az éjjeliszekrény buddhisták pedig azok, akik az éjjeliszekrényükön tartják pl. a buddhista meditáció gyakorlásáról szóló könyvet, ezt olvassák elalvás előtt, és reggel ébredés után meditálnak az olvasottak alapján. (Tweed [1999], pp. 74-5.) 
mozgalmakra. A tanokban és a gyakorlatban, valamint a szervezet bizonyos szintjén a nyugati buddhizmus nagyon hasonlít azokra a csoportokra, amelyek más ázsiai tradíciók - különösen a hinduizmus, a taoizmus és a szúfizmus - tanárai körül alakultak ki. Bár a szókészletük és a kulturális stílusuk gyakran nagyon eltérő, a mögöttük rejlő szándék sokszor szinte megkülönböztethetetlen. A nyugati buddhista tanítók szívesen idéznek Lao-cétől, Rúmitól vagy Nisargadattától, mint ahogy más tradíciók tanítói is különböző buddhista mesterektől. Mindezek (és a keresztény miszticizmus, valamint az olyan független filozófusok, mint Krishnamurti) hasonlósága (azon kívül, hogy a buddhizmus a hinduizmussal egy helyen született meg, valamint a buddhizmus, a szúfizmus és a taoizmus történelmi találkozásaitól eltekintve) leginkább azzal magyarázható, hogy mindannyian hasonló körülmények között kezdtek neki hasonló keresésnek, és hasonló célhoz érkeztek el. (Coleman [2002], pp. 222-3.)

\subsubsection{Elkötelezett buddhizmus}

Bár Nyugaton is a buddhizmus számos ága van jelen, az általánosságban tehát elmondható, hogy a buddhista út a kolostorokból a mindennapi élet terepére helyeződött át. Ennek az áthelyeződésnek egy hangsúlyos példája a „társadalmilag elkötelezett buddhizmus". A kezdeményezés elindítója Thich Nhat Hanh volt, és szellemisége más buddhista irányzatokénál közelebb állhat a nyugati ember aktívabb mentalitásához. Az elkötelezett buddhizmus követői nemcsak a hagyományos buddhista gyakorlásokat végzik, hanem úgy gondolják, hogy a társadalmi színtéren is hasznosíthatják a megszerzett tudásukat. David R. Loy zen tanító What's Buddhist about Socially Engaged Buddhism című írásában azt világítja meg, hogyan lehet a dualisztikus gondolkodásmód megszüntetésének buddhista alapelvét a társadalom szintjén is megvalósítani.

Loy azt mondja, hogy mindannyian folyamatosan szembesülünk a különféle társadalmi problémákkal, igazságtalanságokkal, és bár hasznos az olyan közvetlen segítség is, mint pl. az ingyenkonyhák működtetése, ez csak „sebtapasz”, és nem fogja megoldani az olyan nagy társadalmi gondokat, mint amilyen a hajléktalanságé. Emellett az ilyen problémák megoldásában való egyéni szerepvállalás - mivel érzelmileg nagyon megterhelő - a spirituális gyakorlás nélkül könnyen vezethet 
kiégéshez. De ezen a praktikus szemponton túl az még fontosabb, hogy a spirituális dimenzió nélkül nem érthetjük meg igazán az alapvető problémát, és ennek megfelelően nem is fogjuk tudni megoldani. Így fordulhat elő az, hogy egy adott társadalmi probléma megoldási kísérlete végül a kiindulásinál is rosszabb helyzethez vezet. Valódi megoldást jelenthet azonban, ha megértjük, hogy azokat a buddhista alapelveket, amelyeket a személyes gyakorlás esetében fontosnak tartunk - ilyen elsősorban a szenvedés és az én-tudat közötti kapcsolat felismerése -, a társadalom szintjén is fel kell ismernünk. Ezen a szinten nem az ego, hanem a 'wego', a kollektív én-tudat múködik, amely a saját rasszát, társadalmi osztályát, nemét, nemzetét, vallását stb. a másikkal szemben, a másikról leválasztva határozza meg. Tehát ahogy az egyéni szenvedés oka az ego a másiktól való elválasztottságában, a társadalmi szenvedés oka a wego. A megoldást tehát a kölcsönös függőség felismerése, a dualisztikus gondolkodásmód felszámolása jelenthetné.

A másik fontos alapelv, amely egyéni és intézményi-társadalmi szinten egyaránt működik, a „három káros gyökér” vagy „három méreg”: a mohóság, a rosszakarat és a tudatlanság. Intézményi szinten a mohóság (kapzsiság) ahhoz a nézethez vezet, amely szerint a Föld javai erőforrások, az emberek munkaerők, a pénz pedig tőke, amelyek mind a profit növelését szolgálják. Ugyanezen a szinten a rosszakarat pl. olyan igazságszolgáltatási rendszert eredményez, amely a kisebb bűnelkövetéseket börtönnel sújtja, a nagyokat pedig büntetlenül hagyja, de a legeklatánsabb példája ennek az intézményes fegyverkezés. ${ }^{34}$ Az intézményes tudatlanság körébe tartozik pl. az, hogy a reklámok és a kortárscsoportok nyomása miatt nem vagyunk tudatában annak, hogy a megvásárolt termékeket milyen körülmények között élő emberek készítik. A modern fogyasztói társadalom az intézményes tudatlanság legjobb példája. Mindezen alapelvek fel nem ismerése tehát társadalmi szintű szenvedéshez vezet, amit csak a társadalomról alkotott

\footnotetext{
${ }^{34}$ Loy itt - mind az igazságszolgáltatás, mind a fegyverkezés tekintetében - elsősorban az Egyesült Államokról beszél, ahol egyrészt a börtönökben lévő legtöbb ember olyan nem erőszakos cselekmények miatt került be, mint a kábítószerrel való kisebb visszaélés, másrészt ahol 2004-ben a hivatalos adatok szerint 400 milliárd dollárt költöttek fegyverkezésre, ami becslések szerint megegyezik a világ többi részének összes ilyen költésével.
} 
másfajta kép segíthet csökkenteni. Összességében tehát itt a négy nemes igazság35 társadalmi szintű felismeréséről van szó. (Loy [2004])

\subsubsection{A nyugati és keleti gondolkodás a vallások tükrében}

Az elkötelezett buddhizmus irányzata tehát arra fókuszál, hogyan segíthet a buddhista tan a nyugati társadalmi problémák megoldásában - az előző fejezetben a nyugati buddhizmus ezen dimenzióját kívántam bemutatni. A soron következő fejezetben a keleti és nyugati gondolkodás egy más típusú „összebékítéséről” lesz szó, ami adalékokkal szolgál a vizsgált közösség tagjai vallási identitásának megértéséhez. Látni fogjuk, hogy a közösség tagjai különbözőképpen határozzák meg a vallási hovatartozásukat. Van, aki többes identitással rendelkezik, többen egyáltalán nem tartják magukat vallásosnak, és van olyan is, aki csak azért sorolta be magát valahova, mert az interjú során erre rákérdeztem. Ugyanakkor a tágabb, az intézményes forma helyett a személyes élményt középpontba helyező vallásértelmezésnek megfelelően a megkérdezettek többsége tekinthető vallásosnak, vagy óvatosabban fogalmazva: vallásos érzülettel rendelkezőnek, illetve spirituális útkeresőnek. Az interjúkból kiderült, hogy a nem-vallásosság állítása leginkább a vallás intézményes, valamint kizárólagos formájához kötődik. A vallásdefiníciók persze az egyes kutatóknál eltérnek, és természetesen elfogadható az, ha a különböző forrásokból „összemixelt” nézetrendszereket valaki nem tekinti ebbe a körbe tartozónak. Az alábbiakban azonban szeretnék bemutatni néhány olyan értelmezést, amely valamilyen módon „megengedi” ezt a fajta keveredést.

\footnotetext{
35 Buddha alaptanítása a négy nemes igazság:

1. A szenvedésről: „Szenvedésteli a születés is, az öregség is, a betegség is és a halál is. Szenvedésteli a kellemetlennel együtt lenni és a kedvest nélkülözni. Szenvedésteli az is, ha a kívánság nem teljesül." 2. A szenvedés keletkezéséről: „Nem más ez, mint a folyton újraéledő, örömmel és szenvedéllyel járó, hol ebben, hol abban örömét lelő szomjúhozás, éspedig az élvezetek szomjúhozása, a legyen szomjúhozása és a ne legyen szomjúhozása."

3. A szenvedés kiküszöböléséről: „Nem más ez, mint a szomjúhozás kiküszöbölése, elhagyása, elvetése, elengedése, be nem fogadása a teljes szenvedélymentesség révén."

4. A szenvedés kiküszöböléséhez vezető útról: „Ez maga az arija nyolcrétű ösvény, éspedig a helyes nézet, a helyes szándék, a helyes beszéd, a helyes cselekvés, a helyes megélhetés, a helyes erőfeszítés, a helyes tudatosság, a helyes szamádhi." (A szamádhi az elmélyült meditáció. A páli arija - szanszkrit árja - szó valaha az indoeurópai nyelveket beszélő népek önmegnevezése volt. Buddhánál, úgy túnik, semmilyen etnikai tartalma nincs, tulajdonképpeni jelentése annyi, hogy 'buddhista'. Leggyakoribb fordítása: 'nemes'.) (Szilágyi-Hidas [2013], pp. 39-43.)
} 
Ehhez két, a zennel magas szinten foglalkozó jezsuita szerzetes, Stefan Bauberger és William Johnston, valamint a bencés rendbe tartozó, élete végén Swami Dayananda néven is ismert Bede Griffiths munkáit használom fel.

Stefan Bauberger a Nyitottan a teljességre című munkájában arra keresi a választ, hogyan egyeztethető össze a keresztény hit a zen gyakorlatokkal. A könyve a saját spirituális útjának hozadéka, ebből a nézőpontból írja le, mit jelent számára a kettős vallási identitás: a zen buddhizmusban való elmélyülés révén újra és mélyebben felfedezte a kereszténységet. Ez nem meglepő fordulat; a nyugati buddhizmussal kapcsolatos kutatásokban rendszeresen előkerülnek ilyen jellegű tapasztalatok a laikusok esetében, és a saját terepmunkám során is találkoztam ezzel a jelenséggel. Baubergernél azonban nem puszta érdeklődésről van szó, hiszen jezsuita szerzetessége mellett gyakorló zen mester is. Ebből a kettős mély elkötelezettségből fakadóan hangsúlyozza azt is, hogy a zen gyakorlás bátorítása nem történhet azzal a hátsó szándékkal, hogy az egyház visszacsalogassa az elidegenedett híveket, vagy elcsábítsa más vallások híveit. Sokkal inkább arról van szó - utal Karl Rahner jezsuitára -, hogy a nyugati kultúra individualizálódása miatt a „holnap kereszténye misztikus” lesz, és ezt a fajta közelítést a keleti vallásokban való elmélyülés elősegítheti. A misztikus tapasztalat közvetlen, amivel összhangban áll a zen tanítása: a gondolkodás és a szavak eltávolítanak a lényegtől. Bauberger azonban nem ért egyet azzal a vallásokon átívelő felfogással, amely szerint a vallások csak eszközök a misztikus tapasztaláshoz: a lényeg a csúcsra való feljutás, az mindegy, milyen módon történik ez. Szerinte a vallások éppen különbözőségük révén hathatnak megtermékenyítően egymásra, és a zent gyakorló keresztények számára ez a dialógus, a vallásos alapok ebből fakadó megrendülése, majd a saját valláshoz való visszatalálás lehet az út. (Bauberger [2014], pp. 7-23.)

William Johnston Christian Zen című könyvében szintén gyakorlati oldalról közelíti meg a kérdést. Baubergernél, Johnstonnál és majd Griffithsnél is feltétlenül ki kell emelni azt, hogy - a zen tanításaival összhangban - fejtegetéseikben nem elméleti konstrukciókra, hanem a saját tapasztalataikra és belátásaikra támaszkodnak. Johnston húsz évet töltött Japánban, zen meditációkra járt, és buddhistákkal beszélgetett. Ez nagyon gazdagító volt számára, elmélyítette és kiszélesítette a keresztény hitét. Úgy gondolja, hogy ha a szülőföldjén, Írországban maradt volna, türelmetlen és szúklátókörű pápistává válik, aki protestáns 
ellenfeleire dobálja az utcaköveket Belfastban. Nem tagadja, hogy a zent gyakorló keresztény szembesül bizonyos problémákkal, pl. a meditáció módszere elsőre ateistának vagy panteisztikusnak tűnhet. ${ }^{36}$ Ennek megfelelően furcsa lehet, hogy egy katolikus pap meditál egy zen templomban - úgy tűnhet, hogy összekever dolgokat. Azonban a meditáció révén idővel világosság válik, ami a buddhista intuícióban tükröződik: hogy a legmagasabb bölcsesség nem a karteziánus tiszta és világos elképzelésekben, hanem a nyugodt csendben van, amely túlmutat a gondolatokon, képeken, elképzeléseken, okfejtéseken. Johnston így meggyőződött arról, hogy a keresztényeknek értékelniük és promotálniuk kell más vallások igazi értékeit, valamint az is nyilvánvaló lett számára, hogy a kereszténység főleg azért nem lett igazán sikeres Ázsiában, mert elutasította, hogy a helyi kultúrából és vallásból merítsen. ${ }^{37}$ Ezért felteszi a kérdést: mit tanulhatnak a keresztények a zenből? Saját tapasztalata az, hogy mindenekelőtt az ima módszerét: az ülést, légzést, az elme kontrollját, de a középpontban a ragaszkodás megszüntetése áll. (Johnston [2003], pp. 1-16.)

Bede Griffiths szintén gyümölcsözőnek tartaná a Kelet és Nyugat „házasságát”. Azért ezt a kifejezést használja, mert úgy gondolja, hogy amint az egyes emberben is megvan mind a maszkulin, mind a feminin oldal, és ezek bizonyos egyensúlyát vagy harmóniáját kellene elérni, úgy a világban is erre kellene törekedni. Ezzel szemben „a mai Nyugaton a férfias oldal, az elme racionális, aktív, agresszív ereje uralkodik, miközben a Keleten a nőies aspektus, az elme intuitív, passzív, együtt érző ereje dominál”. „A Nyugat iparosított társadalma az erőszakos, agresszív, racionális nyugati gondolkodásmód terméke”, és „a Nyugatnak a Keletre gyakorolt hatása az agresszív erőszak formáját ölti magára: hol fegyveres erővel, mint a múltban, hol pedig a tudomány és a technikai fejlődés embert és természetet kizsákmányoló, finomabb erőszakosságával, mint azt manapság tapasztalhatjuk”. (Griffiths [2006],

\footnotetext{
${ }^{36} \mathrm{Az}$ egyik mélyinterjúból hasonló - a faragott szobrokkal kapcsolatos - probléma tűnt ki, amelyet azonban a megkérdezettnek sikerült feloldania. Lásd a közösség vallásosságáról szóló részben.

37 „Túlzott leegyszerűsítés lenne-e azt mondani, hogy a Kelet az egységet hangsúlyozza, a Nyugat pedig a sokszínűséget? És hogy szükségük van egymásra? Vagy jobb azt mondani, hogy a misztikus Kelet azt tanítja nekünk kissé meglepő módon, hogy minden egy, míg a tudományos Nyugat remekül ragadta meg a sokféleséget és a számosat? És hogy szükségük van egymásra. Talán tartózkodnunk kellene az ilyen vad általánosításoktól, de mégis szeretek így gondolkodni a zennel való párbeszédünkről." (Johnston [2003], p. 29., fordítás: H. O.) Ugyanakkor a könyv egy későbbi pontján Johnston megjegyzi, hogy egyre több keresztény van Japánban, nyugatiak és keletiek is.
} 
pp.9-10.) Griffiths úgy gondolja, hogy ezt a szemléletet az egyházakban is érvényesíteni kellene, és a kereszténységnek el kellene sajátítania azt, amit a hinduizmus, a buddhizmus és a taoizmus taníthat neki. Ő úgy látja, hogy a tudatosság és spirituális bölcsesség új korszaka van megszületőben, aminek útját egyébként maga a tudomány is egyengeti. Ezzel kapcsolatban Heisenbergre utal, aki szerint: „A természettudomány nemcsak egyszerűen leírja és magyarázza a természetet, hanem a természet és a közöttünk lévő kapcsolat részét képezi." Ez tulajdonképpen lefordítható a keleti gondolkodásra: „a tudomány nem a valóság mint olyan ismeretét adja, hanem az emberi tudaton keresztül tükröződő valóság ismeretét”. (Griffiths [2006], pp. 29-30.) A buddhista tanítások és meditációk célja pedig éppen az ilyen belátások megszerzése.

E három szerző munkáját - bár nem tudományos munkák - azért tartottam fontosnak itt említeni, mert nem pusztán a vallások társadalmi jellegű összebékítésére irányulnak (bár természetesen az sem lenne lebecsülendő), hanem a szerzők saját gyakorlásából szerzett mély belátásokat tartalmaznak. Ennek megfelelően jól érzékeltetik azt, mit adhat a nyugati ember számára a keleti gondolkodás, vallások megismerése, a gyakorlatok elsajátítása, és milyen tapasztalatok és problémafelismerések motiválják a nyugati embert a Kelet felé fordulásra. A következő fejezetben - Griffiths iménti párhuzamára építve a buddhista és a tudományos világkép nyugati összeegyeztetésének kísérleteiről lesz szó.

\subsubsection{A buddhizmus és a tudomány kapcsolódása}

A tudomány és a buddhizmus kapcsolatáról Albert Einstein azt mondta, hogy „ha létezik olyan vallás, mely megállja a helyét a modern tudományos igényekkel szemben is, akkor az a buddhizmus". Itt nemcsak az emberi agy és elme működését vizsgáló tudományokról van szó, hanem például a (kvantum)fizikáról, közgazdaságtanról, nyugati filozófiáról is. Albert Einstein mellett szimpatizált a buddhizmussal többek között Niels Bohr, Francis Crick, Jean Piaget, Robert Oppenheimer és Bertrand Russell is - ha a XX. század első felének neves tudósait, gondolkodóit vesszük. Ez a kompatibilitás lehetővé teszi a buddhista tan számára, hogy utat találjon a tudományos világnézet híveihez is. 
Bár nem kevésbé érdekesek a fizika és a közgazdaságtan buddhizmussal való kapcsolódási pontjai, a jelen fejezetben pszichológiai, kognitív tudományi és idegtudományi megfontolásokról lesz szó. A nyugati buddhizmus kapcsán már felmerült D. T. Suzuki neve, akinek jelentős szerepe volt a zen nyugati megismertetésében, nem utolsósorban éppen a nyugati pszichológia iránti érdeklődése miatt. Az 50-60-as évek már említett „zen boomja” idején azonban a buddhizmus és a pszichoterápia „még csak áttételesen került kapcsolatba egymással”38 - írja Pressing Lajos. Suzuki kifejezett integrációs tevékenysége mellett más olyan pszichológusokat is említhetünk már a XX. század első feléből is, akik vagy kifejezetten érdeklődtek a buddhizmus iránt, mint Jung, vagy akiknek megfigyelései bizonyos pontokon összecsengenek a buddhizmus elképzeléseivel, mint Freudé. Ez az érdeklődés aztán a XX. század végén és napjainkban erőre kapott, és jelenleg a tudomány új lehetőségeket keres a buddhizmus ősi bölcsességének felhasználására.

A buddhizmus és pszichológia/kognitív tudomány/idegtudomány kapcsolódási pontjait feszegető tanulmányok jellemzően kiemelik azt, hogy a nyugati vizsgálódások elsősorban az elme és az agy sérüléseire irányulnak, tehát a szakembereket a „normálistól” való fizikai, gondolkodásbeli és viselkedési eltérések foglalkoztatják, miközben elhanyagolják a pozitív irányú eltéréseket (amilyenek a pozitív teljesítmények és kapcsolatok vagy a hősi tettek). Az pedig, hogy csak az emberi elme inadekvát vagy hibás adaptálódásának kifejeződéseire fókuszálnak, az elmével, aggyal, emberi potenciállal kapcsolatos tudományos modellek korlátozottságát eredményezi, még ha érthető is eme szűkebb fókusz oka: ezek a vizsgálódások a szenvedés különféle formáira való természetes válaszként jelentek

\footnotetext{
38 A „keleti kultuszok iránti érdeklődést ugyanaz az útkereső nyugtalanság és a kiüresedő konvenciókból való menekülés mozgatta, mint amely a különféle kiscsoportos szerveződések, csoportterápiás és személyiségfejlesztő módszerek hirtelen felvirágzását. A buddhista szeánszokon való részvétel éppúgy a tudatosan választott deviancia, de legalábbis nonkonformizmus jele volt, mint a - nem ritkán LSD bevételét vagy marihuána szívását kísérő - különleges tudatállapotokkal való ismerkedés, vagy a pszichológiai önismeret kiscsoportos technikáinak alkalmazása. Az ekkoriban kibontakozó, a hagyományos pszichoterápiás elvekkel gyakran gyökeresen szakító új csoportos módszerek azóta a pszichoterápiás eszköztár elfogadott technikáivá váltak. Ezek némelyikén, pl. a Petzold-féle Gestalt-terápián jól felismerhető a forrásvidéken felszedett buddhista eszmék hatása, amennyiben a pszichológiai tünetek oknyomozó feltárása helyett a hangsúlyt áthelyezik az itt-és-mostban való tudatos jelenlét elsajátítására, az érzelmi görcsök és lélektani blokádok attitûd-változtatással és magatartás-tréninggel történő feloldására." (Pressing [1998])
} 
meg. (Lásd pl. Wallace-Shapiro [2006], p. 690. és Quaglia [2011], pp. 1., 6.) Ehhez a szűkebb perspektívához tud a buddhizmus sokat hozzátenni azzal, hogy magát a szenvedést is tágabban határozza meg, nem a klinikai kórképekre redukálva azt, hanem a létezés alapvető természetének tekintve, ami által lehetőséget teremt a klinikai értelemben egészséges emberek további pszichés, mentális fejlődésére. A pszichológia pedig elszakadhat a korábbi megközelítéstől, és nagyobb hangsúlyt kaphat a betegségek megelőzése.

\subsubsection{A pszichológia, kognitív tudomány és a buddhizmus határterületei}

A témában elérhető tanulmányok abban megegyeznek, hogy igyekeznek megkeresni a közös pontokat, amelyekből a szerzőik szűkebb érdeklődési területének megfelelő irányba mozdulnak el. Ilyen közös pontok például Alan B. Wallace és Shauna L. Shapiro Mental Balance and Well-Being: Building Bridges Between Buddhism and Western Psychology című tanulmányában, hogy az érzékszervi, intellektuális vagy esztétikai élvezet nem vezet tartós boldogsághoz (a belső mentális tréning tartósabb, mint az ingeralapú élvezet); hogy az elégedettség nem azon múlik, hogy valaki megszerezze, amit akar, hanem hogy azt akarja, amije van; hogy a maximalizmus helyett megfelelőbb az elégedettségre törekvés; hogy (a korábbi pszichológiai elméletekkel ellentétben) a boldogságon folyamatosan dolgozni kell; hogy a mentális szenvedés az elme kiegyensúlyozatlanságából fakad, aminek tünetei a frusztráltság, az idegesség, a depresszió. (Wallace-Shapiro [2006], pp. 691-3.) A szerzők a mentális jóllét természetét tárgyalják a buddhizmus tükrében, és egy olyan innovatív modellt mutatnak be, amely arra vonatkozik, hogyan lehet elérni ezt

a jóllétet a mentális egyensúly négy típusának - akarati (konatív), figyelmi, megismerési (kognitív) és érzelmi (affektív) - kiművelésével.

A konatív típus lehetővé teszi a szándékok, célok, prioritások felállítását, ez az alapja a másik háromnak. Fontos megkülönböztetni a vágytól, mivel ez utóbbi nem tartalmazza a megvalósítással kapcsolatos elkötelezettséget. Itt Congkapára hivatkozva szükségesnek tartják eloszlatni azt a félreértést, miszerint a buddhizmus mindenféle vágy vagy cél megszüntetését hirdeti. Nem egy ilyen - gyakorlatilag vegetatív - állapot eléréséről van szó, hanem az egészségtelen vágyak és célok 
megszüntetéséről, amelyek szenvedést okoznak. A pszichológiai praxisban például a függőségek kezelésében használható jól a konatív egyensúly fejlesztése.

A figyelem szükséges készség a következő két típusú egyensúly eléréséhez. Buddhista nézőpontból ennek hiánya úgy írható le, hogy a személy nem képes az adott tárgyra fókuszálni. A hiány ellenszere az éber figyelem/jelenlét (mindfulness), valamint a „meta-figyelem”, vagyis az elme aktuális állapotának monitorozására való képesség fejlesztése. A legelterjedtebb buddhista gyakorlásokban a figyelmi egyensúly kifejlesztése a légzésre vonatkozó éber figyelem révén lehetséges. A pszichológiában ehhez hasonló Csíkszentmihályi flow-koncepciója - a flow olyan állapotot jelez, amikor a személy teljesen elmerül a tevékenységében.

A kognitív egyensúly a világgal kapcsolatos olyan tapasztalás melletti elkötelezettséget jelent, amelyre nem rakódnak rá olyan konceptuális feltételezések vagy eseményekre vonatkozó elképzelések, amelyek félrevihetik vagy eltorzíthatják őket (lásd ezt később Mikulasnál is). A kognitív egyensúly súlyos hiánya (mint amilyen a pszichózis állapota) esetén az ember elveszítheti a kapcsolatát a valósággal. A buddhista nézet szerint a klinikailag egészséges emberek is hajlamosak bizonyos fokú kognitív egyensúlyhiányra. Egy klasszikus példa erre, amikor az ember a feltekert kötelet kígyónak nézi, de idetartoznak azok az esetek is, amikor a figyelemhiány vagy a tudattalan félelmek és remények miatt félreértjük mások érzelmeit, szándékait, attitűdjeit. A pszichológiai alkalmazás tekintetében itt említhető a mindfulness-alapú stresszcsökkentés vagy a mindfulness-alapú kognitív terápia, amelyekkel a klinikai és nem klinikai esetekben is jelentős pozitív hatás érhető el pszichológiai és fiziológiai téren egyaránt.

Végül pedig az affektív egyensúly az első három természetes következményeként áll elő, ugyanakkor az ebben tapasztalható egyensúlyhiány károsítja is a többit. Az affektív egyensúly a túlzott érzelmi ingadozástól, érzelmi apátiától és nem megfelelő érzelmektől való mentességként írható le. Tulajdonképpen az érzelmi szabályozásra való képességgel feleltethető meg. A buddhizmusban az ilyen egyensúlytalanságra az olyan tulajdonságok kifejlesztése a gyógyír, mint a szerető kedvesség, az együttérzés, az empátia révén érzett öröm és az egykedvű nyugalom. A pszichológiában ez az a terület, ahol épphogy csak elkezdődtek a kutatások, de már végeztek olyan randomizált, kontrollált vizsgálatot krónikus fájdalommal élő betegeknél, amely azt mutatta ki, hogy a 
szeretőkedvesség-meditáció jelentősen csökkenti a fájdalmat és a pszichés megterhelést. (Wallace-Shapiro [2006], pp. 693-8.)

William L. Mikulas Buddhism and Western Psychology: Fundamentals of Integration című tanulmányában csupán a közös pontok keresésénél még talán eggyel tovább megy, és egy olyan értelmezéssel áll elő, amely szerint a buddhizmus valójában nem is vallás vagy filozófia, hanem pszichológia - legalábbis a nyugati pszichológia szemszögéből, eltávolítva a számára szükségtelen vallási asszociációkat és interpretációkat. Mikulas a buddhizmusnak egyrészt az általában vett pszichológiához, másrészt különösen a kognitív tudományhoz, a viselkedésmódosítási elméletekhez, a pszichoanalízishez és a transzperszonális pszichológiához való hozzájárulását vizsgálja egy átfogóbb („konjunktív”) pszichológia és hatásosabb terápiák kidolgozása érdekében. Olyan buddhista alaptanításokat használ fel ehhez, mint a szenvedés (dukkha), a ragaszkodás, a négy nemes igazság, a nemes nyolcrétű ösvény, a koncentráció és az éber figyelem/jelenlét tanítása. Nála és másoknál (pl. Lutz et al. [2007]) is fontos alátámasztó szerepet kap a páli kánon egyik könyve, a buddhista „pszichológiát” tartalmazó Abhidharma.

Mikulas az említett négy területtel kapcsolatban tekinti át, mit tud számukra kínálni a buddhizmus. A kognitív tudomány ${ }^{39}$ számára általánosságban elég sokat, beleértve az Abhidarmában foglalt átfogó „kognitív tudományt” is. Az Abhidharma az elme kritikusan felbontott, részletes térképét tartalmazza a tudati és mentális tényezők sorozataira lebontva. Magában foglalja a dharmákkal, a tudati valóság elemeivel kapcsolatos elemző tapasztalatot, továbbá a dharmák, valamint az elme és a tudatosság más alapvető összetevői osztályozásának és csoportosításának számos különböző rendszerét tartalmazza. Felsorolja azokat az egészséges és nem egészséges tényezőket, amelyek segítik vagy hátráltatják a meditációt, valamint a személyiség és az elme egészségének alapjául szolgálnak. A modell - az egészséges tényezők fejlesztése és az egészségtelenek kiegyenlítése - a pszichoterápiában is alkalmazható: a belátás és az éber figyelem kiművelése például csökkenti a téves

\footnotetext{
${ }^{39}$ A kognitív tudomány az Egyesült Államokban leginkább az információfeldolgozó számítógépes szimulációs modellt jelenti, de megemlítendő egy alternatív modell - az elme viselkedési modellje is, amelynek erősségét annak a terápiára, személyes/spirituális fejlődésre, oktatásra, sportra és művészetre alkalmazható következményei adják. (Mikulas [2007], p. 28.)
} 
képzeteket/tévhiteket, amelyek egyébként akár paranoiához is vezethetnek. Mikulas szerint az Abhidharma és a kognitív tudomány kapcsolódásának felfedezése épphogy csak megkezdődött, és nagy lehetőségek vannak még benne. (Mikulas [2007], pp. 29-35.)

Egy másik átfogó terület a viselkedésmódosítás, amely magában foglalja a viselkedésterápiát, a kognitív viselkedésterápiát és az alkalmazott viselkedéselemzést. A viselkedésmódosítás és a buddhizmus közös abban, hogy mindkettő kiemeli a valóság olyan érzékelését, ahogyan az van - a lehető legkisebb torzítással és értelmezéssel, kerülve az elméleti és metafizikai konstrukciókat (amelyek nemcsak nehezen mérhetők, de kérdéses a hasznosságuk is). (Erről beszélt Wallace és Shapiro is a kognitív egyensúly kapcsán.) Mindkettőre jellemző, hogy ahistorikus, és az itt és most-ban való teljesebb életre fókuszál. Ezenkívül bátorítják a nagyobb fokú tudatosságot a test, az elme és az érzelmek tekintetében, és hangsúlyozzák a tanulással megszerezhető önszabályozási készségeket ${ }^{40}$. Azt állítják, hogy bár a tanítók, a társak és mások sokféleképpen segíthetnek, a legjobb rendszerint az, amikor valaki vállalja a felelősséget a saját életéért, beleértve a viselkedését is. Ezenkívül mindkettőben megvan az ellenkondicionálás módszere: a thai szerzetesek például gyakran adják azt a tanácsot, hogy a rosszindulat kioltását a barátságosság, az irigység kioltását pedig az együtt érző öröm kiművelésével lehet elérni. ${ }^{41}$ (Mikulas [2007], pp. 35-7.)

\footnotetext{
40 A viselkedésmódosítás és a buddhizmus kapcsolatáról szóló első tanulmány - amely a zen meditációt és a viselkedési önszabályozást hasonlította össze - 1976-ban született meg: Shapiro, D. H., Jr. - Zifferblatt, S.: Zen meditation and behavioral self-control. American Psychologist, 31, pp. 519-32.

${ }^{41}$ Az ellenkondicionálás gyakran előfordul természetes módon a meditációk során: amikor negatív gondolatok vagy emlékek merülnek fel valakiben, akkor ha a meditáció révén elért nyugalmi vagy relaxált állapot uralkodni tud a negatív gondolatokon, az ellenkondicionálás létrejön.

Népszerű és hatásos példája a buddhista ellenkondicionálásnak a szeretőkedvesség-meditáció, amelynek sokféle formája van. Ilyen például az, amikor a meditáló bizonyos sorban meditál embereken: először olyanra gondol, akit szeret, utána aki közömbös számára, végül akit nem szeret. Mindeközben végig megtartja a szerető kedvesség érzését. Ez nagyon hasonlít a szisztematikus deszenzitizációs ellenkondicionáló terápiához, azzal a különbséggel, hogy a szeretőkedvességmeditációban az első személy kifejezetten pozitív, nem pedig semleges, és a negatív érzelmeket szeretettel ellenkondicionálja. Hasonló ez Jézus „szeresd ellenségeidet” intéséhez, amely erőteljes spirituális tanács, de a fenti hierarchikus megközelítés nélkül sokszor nehéz kivitelezni. (Mikulas [2007], pp. 37-8.) A szeretőkedvesség-meditációra egyébként a Szelíd Mosoly szangha elvonulásain is sor kerül - a kutató számára ez a meditáció a terepmunka során mindkét alkalommal erőteljes élményt jelentett.
} 
A tárgyalt területek közül a buddhizmus és a pszichoanalízis összekapcsolása tekint vissza a leghosszabb múltra: ennek jelentős és változatos irodalma van, amelynek a legnagyobb része a zenre fókuszál. Ha a hasonlóságaikat nézzük, a legfontosabb elem, hogy mindkettő a mindennapi élet szenvedésének csökkentésével foglalkozik, valamint hogy a tapasztalati megközelítést alkalmazza a személyes valóság (beleértve az észleléseket, érzelmeket, az én érzetét) dinamikájának feltárásában. Az ember lényének átalakításában mindkettő a tiszta észlelés, a valóság ismerete és az én természetével kapcsolatos belátás kifejlesztését hangsúlyozza, a személyes fejlődést és az elnyomó erőktől való megszabadulást ösztönzi. Mikulas Mark Epsteinre utal, aki szerint Buddhát lehet az első pszichoanalitikusnak tekinteni, ráadásul Freudra és Buddhára is igaz volt, hogy saját magukon alkalmazták az eljárásaikat. (Mikulas [2007], p. 41.)

A negyedik terület a transzperszonális pszichológia, amely a dolgozat szempontjából azért is különösen érdekes, mert a Szelíd Mosoly Buddhista Szangha gyökerei is ide nyúlnak vissza: Jan Boswijk először a Magyar Transzperszonális Egyesület meghívására érkezett Magyarországra, ahol aztán éveken keresztül tartott pszichoterápiás csoportokat, és mentora lett a transzperszonális pszichoterápiás képzésnek is. A transzperszonális pszichológia a pszichológiának egy meglehetősen új határterülete, amely az ember spirituális oldalát is elismerve a személyes, én-központú szinten túlmutatva az emberi lét, élet, psziché és kozmosz tágabb perspektíváit is felöleli, spirituális és transzcendens tudatállapotok felismerésével, megértésével és megvalósításával foglalkozik. Mikulas tanulmányában hangsúlyozza, hogy a buddhizmusban a transzperszonális szint feltárása alapvető fontosságú, a buddhista gyakorlás - egyéb hasznai mellett - végső soron erre irányul. A Mikulas által javasolt konjunktív pszichológia álláspontja szerint mindenki négy teljesen egybefonódó szinten létezik: biológiai, viselkedési, perszonális és transzperszonális szinten. A biológiai szint a test (az agyat is beleértve) tartománya; a viselkedési szint a test aktivitása (a kogníciókkal együtt), a nyilvánvaló és rejtett viselkedések területe; a perszonális szint a tanult, tudatos, személyes realitásé (beleértve az én és az akarat érzését); a transzperszonális szint pedig annak a létezésnek az erőit és tartományait jelenti, amely felettes és/vagy elsőbbleges az én-központú személyes realitáshoz képest (ide tartoznak a személyes realitást és az én érzetét megteremtő dinamikák). A személyes szint a 
tudat tartalmaira (így az énre mint tárgyra) fókuszál, a transzperszonális szint ${ }^{42}$ pedig a tudat folyamataira és a tudatra önmagában mint az alapvető ok aspektusára. Az ember a fejlődése és személyes növekedése során elveszik a létezés személyes szintjében; az elméje tartalmát összetéveszti valamilyen feltételezett konkrét realitással, és a funkcionális személyes szinten lévő én-nel azonosítja magát. A buddhizmusban az ehhez az illuzórikus én-hez való ragaszkodás a fő forrása a téves megismerésnek és a szenvedésnek. A megvilágosodás az e ragaszkodástól való megszabadulással és a transzperszonális szintet is magában foglaló tágabb realitásba való felébredéssel érhető el. E felébredés lehetősége és természete azonban nagy kihívást jelent az akadémikus pszichológia számára. (Mikulas [2007], pp. 9., 46-8.)

\subsubsection{Kritikai észrevételek}

A fentiekből jól látszik, hogy a buddhizmus és a tudomány között kapcsolatokat keresők elsősorban a hasonlóságokra fókuszálnak, és ez vonatkozik a meditáció tudományos igényű vizsgálataira is. Ugyanakkor felmerülhet az a kérdés - amit Bernard Faure fel is tesz -, hogy a buddhizmus tudománnyal való összeegyeztetés érdekében elvégzett modernizációja milyen következményekkel jár a buddhista tanra nézve. Úgy tűnik, hogy itt egy aszimmetrikus viszonyról van szó, és a buddhista tan tudományos keretek közé szorítása történik meg, aminek révén kikerül belőle a hit, a rituálé, a vallásos narratívák és más olyan elemek, amelyek nem kompatibilisek a tudományos világnézettel. Ez a buddhizmusnak egy olyan erősen szelektív meghatározását eredményezi, amely történelmi szempontból teljesen inadekvát. (Jó példa erre a Dalai Láma, aki központi szerepet kapott a buddhizmus és az idegtudomány párbeszédében, mindamellett a személyében egy olyan vallási vezetőről beszélhetünk, akit a követői Avalókitésvara bódhiszattva inkarnációjának tekintenek.) És bár valóban vannak szemléletbeli hasonlóságok a buddhizmus és a tudomány között (mint amilyen a tapasztalat/kísérlet értékének hangsúlyozása vagy a kritikai gondolkodás), a buddhizmus nem redukálható ezekre

\footnotetext{
${ }^{42}$ Míg a pszichoanalízis és a humanisztikus pszichológia elsősorban a személyes szinttel foglalkozik, a transzperszonális pszichológia pedig a transzperszonális szinttel, a konjunktív pszichológia mind a négy említett szinttel és azok interakcióival.
} 
a sajátosságokra. Ott van ugyanis a hit kifejezése: a menedékvétel a három ékkőben, a Buddhában, a Dharmában és a Szanghában. ${ }^{43}$

Faure ezért azt javasolja, hogy a buddhizmus és az idegtudomány konvergenciájával kapcsolatos irodalmat (beleértve Lutz et al. feljebb hivatkozott tanulmányát) jóval kritikusabb és gondosabb szemmel kell olvasni, ami a jelenség józanabb értékeléséhez vezet. Így pl. a meditáció tekintetében nem szabadna figyelmen kívül hagyni a kulturális különbségeket annak érdekében, hogy a mentális állapotok megfeleltethetők legyenek. A buddhista meditáció kapcsán a Lutzék által megfogalmazott fő kutatási területeken (neuroplaszticitás, a test és elme együttműködése, a szubjektív tapasztalat neurális megfelelőinek lehetősége) még nem áll rendelkezésre elég adat, és nem veszik figyelembe a meditációs technikák sokféleségét és különösen azt, hogy a meditáció nem egy kötetlen gyakorlat, hanem konkrét kulturális, rituális és szoteriológiai feltételei és jelentései vannak. A buddhista út hagyományos felfogásában a meditáció a hit és a moralitás kontextusában értelmezendő. A moralitásra alapul, és a bölcsesség emelkedéséhez vezet. Ha ezek közül bármelyik hiányzik, a gyakorló könnyen zsákutcában találhatja magát. Mindazonáltal a párbeszéd lehetősége továbbra is fennáll, azonban ehhez mindkét oldalnak el kell fogadnia a másik oldal másságát. (Faure [2012])

\subsubsection{Az „Easternization thesis” és kritikája}

A nyugati buddhizmus bemutatott jellegzetességeihez és történetéhez, valamint a tudománnyal való párbeszédhez és Faure kritikájához kapcsolódva szeretnék bemutatni egy a fentieket értelmező elméletet és annak kritikáját.

Az Easternization thesis a keleti vallások Nyugatra való hatásgyakorlásának jelenségét igyekszik magyarázni. Az elmélet legradikálisabb változatát a legszisztematikusabban Colin Campbell dolgozta ki The Easternization of the West: A Thematic Account of Cultural Change in the Modern Era című könyvében. ${ }^{44}$ Campbell itt arra keresi a választ, hogy ha a globalizáció alapvetően nyugatosodást

\footnotetext{
${ }^{43}$ A menedékvétel a buddhista út melletti elköteleződés aktusa, leírását lásd később.

44 A következőkben nem a könyvből, hanem az ennek téziseit összefoglaló tanulmányból idézek, amely az Asian Journal of Social Science folyóiratban jelent meg 2010-ben, és amelyet Campbell professzor bocsátott a rendelkezésemre Word formátumban, amit ezúton is köszönök neki.
} 
jelent a Keleten, akkor mindeközben mi történik magával a Nyugattal? Feltételezhető-e, hogy egy fordított folyamat zajlik itt? Erre utalna az, hogy a 60-as évektől kezdve nyilvánvaló lelkesedés mutatkozik a „keleti dolgok” iránt a nyugati országokban - ilyen pl. a feng shui térrendezés ősi kínai taoista gyakorlata, a keleti orvoslás, terápia és masszázs, a már a nyugati orvoslásba is beépülő technikák, mint az akupresszúra és az akupunktúra, a harcmúvészetek a kapcsolódó iskolákkal és irányzatokkal, valamint ide tartozik a keleti vallások (a buddhizmus és a hinduizmus, különösen a Haré Krisna mozgalom) kiugró népszerűsége. A nyugati állampolgárok tehát a Kelethez fordulnak segítségért és inspirációért. Campbell szerint azonban a nyugatosodás és a keletiesedés alapvető mechanizmusai között van egy nagy különbség: a nyugatosodás nagyrészt azért történik, mert a Nyugat hatalmat gyakorol a többi civilizáció felett - katonai, gazdasági, politikai és kulturális tekintetben is. Ebben az értelemben a Nyugat uralkodik a Keleten (vagyis tette azt a közelmúltig). A keletiesedés ezzel szemben nem jelent ilyen uralmat, sokkal inkább arról van szó, hogy a Kelet (vagyis a Nyugat Keletről alkotott képe) erőteljes hatást gyakorol a Nyugatra. Ennek a különbségnek a valódi jelentősége abban rejlik, hogy a kívülről érkező elképzelések és gyakorlatok által az emberek bármely csoportjára tett hatáshoz nyitottnak kell lenni az ilyesféle hatásra, és ez a nyitottság a saját kultúrával vagy életmóddal kapcsolatos elégedetlenséget is maga után vonja.

A Keletről származó kulturális anyag tényleges jelentősége tekintetében azt mondja Campbell, hogy az viszonylag csekély szerepet játszott a Nyugat keletiesedésében - ehhez inkább a magán a nyugati civilizáción belüli fejlemények járultak hozzá (mint a természet és a természetes koncepciójának rehabilitációját elősegítő mozgalmak: a teljes ételt és holisztikus egészséget hirdető, a környezetvédelmi és állatjogi, valamint az emberi potenciállal kapcsolatos mozgalmak, illetve az asztrológia). A New Age és újpaganista mozgalmak olyan értelmezési rendszert kínálnak, amely magában foglalja az ilyen kísérleteket a (belső és külső) természet rehabilitációja és a „varázstalanítás” 45 visszafordítása érdekében. A varázstalanításnak ez a visszafordítása írható le úgy, mint ami lényegében keleti karakterü.

${ }^{45}$ Weberre utaló fogalom. 
A keleti világnézet a 70-es és 80 -as években ellenkezés nélkül söpört végig a nyugati társadalmakon. Ennek elsődleges okát Campbell abban látja, hogy a nyugati kultúra három főbb ága - a vallás, a szekuláris politikai ideológia és a tudomány - nem tiltakozott e fejlemények ellen, hanem maga is részt vett a keleti világnézethez való alkalmazkodásban, tehát a nyugatosítás megfordításában. Ez utóbbi annak következményeként történt, hogy a XX. század közepére a nyugati világ nem rendelkezett egy koherens, hiteles, jövőképet mutató és morálisan kielégítő, átfogó értelmezési rendszerrel vagy teodíceával. Nemcsak a kereszténység nem felelt meg nyilvánvalóan ezeknek a követelményeknek, hanem a marxizmus később dominánssá váló formájában (a kapcsolódó kommunista és szocialista ideológiákat is beleértve) megnyilvánuló szekuláris, felvilágosodásra épülő, progresszív tradíció sem. Ez a helyzet két uralkodó választ váltott ki: egyfelől (egzisztenciális) dühöt és kétségbeesést a fiatal értelmiségiek körében (eleinte főleg Európában, de később az Atlanti-óceán mindkét partján); másfelől az új középosztálybeli, tanult fiatalok felháborodását és erőszakos fellépését, ami a „morális keresztes háborúk” (polgárjogi mozgalmak az USA-ban, valamint a nukleáris fegyverek leszerelése melletti kampányok az Egyesült Királyságban és Nyugat-Európában) melletti erős személyes elkötelezettségben nyilvánult meg.

Mindezek a kulturális állásfoglalások, amelyek képesek voltak találkozni az új generáció igényeivel, a megfelelő értelmezési rendszer, a „nagy narratíva” hiányára adott válaszként tekinthetők. Ugyanekkor jelentős intellektuális erőfeszítésekre került sor a Nyugat hitelét vesztett vallásos és szekuláris teodíceáinak rekonstruálása érdekében (a protestáns teológiából Bultmann, Tillich és Altizer, a baloldali értelmiségiek köréből pl. a Frankfurti Iskola - különösen Marcuse, Adorno és Horkheimer -, valamint Sartre említhető). Ezek a kulturális rekonstrukciós erőfeszítések bár premisszáikban és meggondolásaikban nagyon különbözőnek tűnnek, olyan hasonló intellektuális tradíciókból származó anyagokat használtak fel, mint az egzisztencializmus, a freudiánus gondolkodás (és általában a pszichoanalízis), valamint a német idealista filozófia. A két rendszer aztán sok tekintetben hasonló „üzeneteket” fogalmazott meg: a kortárs Nyugaton élő embereket körülvevő szomorú és szegényes pszichikai-spirituális körülmények hatásosan csak az egyéni tudatosság radikális „megemelésére” vagy „megváltoztatására” irányuló összehangolt személyes tevékenység révén 
orvosolhatók. Ez lett aztán a kibontakozó New Age mozgalom alapvető premisszája. $\mathrm{Az}$ említett két rendszer mellett a harmadik fontos fejlemény a tudományhoz kapcsolódik: ez az einsteini és a kvantumfizika, amely majdnem az összes tudományos diszciplínában teljesen új világlátást vezetett be. E három fejlemény súlyos csapást mért a hagyományos nyugati világnézetre. Az elmúlt több mint 2000 évre visszatekintve a legnagyobb horderejű változás Campbell szerint, hogy a személyes, transzcendens teremtő Isten elképzelését az immanens és személytelen isteni életerő/hatalom váltotta fel. A második jelentős változás a marxista gondolkodás által fémjelzett szekuláris, utópista tradícióban történt: a kulturális fordulat és a freudo-marxizmus következményeként az egész felvilágosodási projekt - a rációban, tudományban és fejlődésben való hittel együtt - elutasításra került, és helyébe az élvezet alapelvében, a művészetben, az önkifejezésben és az önjutalmazásban megjelenő utópikus lehetőségben való romantikus hit lépett (lásd Marcuse). A harmadik pedig a tudományban magában történt éles paradigmaváltás volt, amely a klasszikus, mechanikus newtoni világnézetet döntötte meg a „vitalisztikus” organikus rendszerek, valamint az ökológián és az új fizikán alapuló kvázi-metafizikai perspektíva javára.

A hagyományos nyugati világnézetet Campbell leegyszerűsítve úgy határozza meg, mint amely materialista dualizmust eredményez, és a dualizmus hangsúlyozása ellentétben áll a Kelet lényegi monizmusával. A dualizmus mindenekelőtt az Isten és ember kettősségében jelenik meg, de ugyanígy az ember és a természet, az anyag és a szellem, valamint az elme és a test kettősségében is. A dualisztikus gondolkodásra való hajlam közel kétezer éve a hagyományos nyugati világnézet központi jellemzője volt, egészen a megkérdőjelezéséig. Először és mindenekelőtt az Isten és a világ kettősségét utasították el, de nemcsak a keresztény eredetű, hanem a szekuláris dualizmusra is igaz ez: az elme és a test, a szubjektum és az objektum megkülönböztetését is elvetették. Ez jól látszik például a kognitív pszichológiából is. (Campbell [2010])

Malcolm Hamilton kritikája elsősorban erre a leegyszerűsítésre irányul, vagyis hogy Campbell egy kalap alá veszi a keleti vallásokat, sztereotip képet fest róluk. Nem veszi figyelembe a közöttük lévő eltéréseket, és bizonyos kiragadott aspektusokat hangsúlyoz, másokat pedig teljesen ignorál. A transzcendens/ immanens Weberre visszavezethető szembeállítása inkább utal az értelmiségiek és 
vallási virtuózok filozofikus, doktrinális vallására, mint a keleti emberek mindennapi gyakorlatában megtestesülő, sokkal elterjedtebb vallásra. Emellett a Nyugatra hatást gyakorló vallások az adott körülményeknek megfelelően jelentősen módosított formában jelennek meg. Jellemző példája ennek Tibet, amelyet a Nyugat úgy kezel, mintha egy meseszerű múlt múzeuma lenne. Bizonyos, a nyugati gondolkodáshoz illeszkedő elemeit átemeli, másokat pedig (mint amilyen a Tiszta Föld buddhizmus) majdnem teljesen figyelmen kívül hagy. Ezenkívül a nyugati buddhizmusra jellemző, hogy inkább az önfejlesztésre, mintsem az én transzcendenciájára helyezi a hangsúlyt. Ha a buddhizmus egy jelentős új kulturális fejleménynek mutatkozik a Nyugaton, az nem azért van, mert a nyugati kultúrát új vallási csatornák felé irányítja, hanem mert a meglévő vallási csatornákat új módokon fedezi fel.

Egy másik probléma Campbell elméletével, hogy a tradicionális Keletet hasonlítja össze a modern Nyugattal. Felmerül az is, hogy a spiritualitás területén tapasztalható közelmúltbeli fejleményeket nem a keleti modell mentén, hanem esetleg inkább a kereszténység előtti idők retradicionalizálásaként lehetne értelmezni. Ez azonban nem ad pontosabb képet a folyamatokról, mint az Easternization thesis, mivel a tárgyalt mozgalmak nagyon sokféle forrásból merítenek. Hamilton azt is felveti, hogy Campbell elmélete arra a feltételezésre épül, hogy ezek a fejlemények vallási természetűek, pedig egy részük jobban értelmezhető a vallástól valamilyen nem-vallásos értelmezési rendszer felé való elmozdulásként, esetleg kvázi-vallásként. Arra maga Campbell is rámutat, hogy e számos forrásból táplálkozó miliő központi eleme az útkeresés. Ennek fő jellemzője a kísérletezés, az érdekes dolgokra való nyitottság és a bármilyen nézetrendszer melletti viszonylag alacsony szintű elkötelezettség.

Mindezek mellett fontos különbség a nyugati megjelenési formák evilági irányultsága és aktivizmusa. Például a taoizmus eredeti egykedvűsége és nemaktivista jellege éles ellentétben van a nyugati megvalósulási formáinak (mint amilyen a mélyökológiai mozgalom) aktivizmusával. A buddhizmus esetében pl. ott látja a problémát, hogy a buddhizmus low-tech, nem pedig high-tech megoldásokat ad a problémákra, így a technológiáért rajongó Nyugaton ezek nem megvalósíthatók. Összességben tehát meglehetően sok probléma van az Easternization thesis elképzeléseivel, Hamilton mindazonáltal hangsúlyozza, hogy 
nem kell teljes mértékben elvetni, de jelentős módosításra, továbbgondolásra és kiegészítésre van szükség. (Hamilton [2002])

\subsubsection{A buddhizmus Magyarországon}

Európa több országában egyházként a buddhizmus a XIX-XX. században talált új talajra. Magyarországon már 1893-ban létezett egy buddhista kör Máramarosszigeten. (Török [2004], p.63.) Ez minden bizonnyal összefügg a magyarországi buddhizmus jeles alakja, Kőrösi Csoma Sándor (1784-1842) tevékenységével, aki megalapozta mind a buddhizmus, mind a Tibet iránti tudományos érdeklődést. Kőrösi Csoma soha nem tagadta meg református hitét, ennek ellenére mint „nyugati tanítványt” 1933. február 22-én a tokiói Taisho buddhista egyetemen szentté avatták: ő lett a nyugati világ egyetlen bódhiszattvája, aki „megnyitotta a Nyugat szívét a Buddha tanítása előtt” (Farkas [1998], p. 8.). A Csoma-kultusz sokszor segítette a buddhizmus érvényesülését, így többek között a szocialista időszak egyfajta „buddhizmust legitimáló szimbólumává” is vált. (Kárpáty [2001], p. 63.)

A magyarországi buddhizmus a jellegzetességeit tekintve a nyugati buddhizmushoz kapcsolódik. Akárcsak Nyugaton, eleinte itt is a teozófusok voltak a leglelkesebb közvetítői, akik a maguk szinkretista-okkult felfogásában népszerűsítették a tant. Eleinte itt is az értelmiségiek és a művészek érdeklődtek iránta, 1931 és 1935 között létezett is egy buddhista szangha Budapesten, amelyet Vágó László nagykereskedő alapított, aki már a húszas években állandó tagja volt a londoni Buddhist Lodge-nak. Ez a kis közösség az ortodox hínajánát mint az „eredeti” buddhizmust próbálta képviselni. Ekkoriban a vallásügyi törvények szigorúsága miatt nehéz volt közösséget alapítani, a háború után azonban ezeket a törvényeket eltörölték, és a különféle felekezeteket egyenrangúnak nyilvánították. Így 1951-ben Dr. Hetényi Ernő vezetésével megalakult az első államilag elismert buddhista közösség, a Buddhista Misszió. A monopolhelyzetnek a rendszerváltás vetett végett, ami abban az értelemben is változást hozott, hogy ettől kezdve a mahájána tradíció nyert teret. Ennek okaként jelölhető meg, hogy a társadalmikulturális körülmények nem megfelelőek a szigorú rendszabályokkal rendelkező 
hínajána gyakorlásához, valamint ennek felfogása is nehezebben illeszthető az európai gondolkodásmódhoz. (Farkas [1998])

A buddhista mikrotársadalomban a 80-as évek végétől kezdődően végbemenő változásokkal kapcsolatban Farkas Attila Márton részletes és meglehetősen kritikus leírást ad könyvében. Kritikája elsősorban arra irányul, hogy ekkortól kezdve másodvonalbeli külföldi tanítók jelentek meg a hazai színtéren, és ez a „nyitás” a mennyiségbeli gyarapodás mellett számos korábbi érték lerombolását is eredményezte. Az addigi „intellektuális” buddhizmus mellett felbukkant
„a devócióra alapozott, »hagyományosabb« vallásosságot megjelenítő alternatíva. E szellemiség ezután a különféle kisebb-nagyobb közösségek megjelenésével egyre jobban eluralja a hazai buddhizmust. Ezzel pedig nálunk is megrendül a nyugati buddhizmus Schopenhauertől kezdődő, főként az értelmiséget megérintő régebbi szellemi hagyománya, amely a buddhista létszemléletet elsősorban az emberi lét nagy kérdéseire az egyén által történő filozofikus válaszkeresésként állítja szembe a főként hitre és érzelmekre alapozott hagyományos vallásossággal (elsősorban a kereszténységgel). És mivel a fő tendencia a nyolcvanas évek végétől kezdődően egyre inkább az intellektust javarészt negligáló, s inkább az érzelmekre alapozott »buddhista vallásosság« elterjedése és vele párhuzamosan (sőt: vele karöltve) az üzleti szellem egyre nagyobb érvényre jutása lesz, így nagyon hamar szétbomlanak a korábban ígéretesnek látszó kezdeményezések is." (Farkas [1998], p. 21.)

Farkas egyébként a buddhizmus felé fordulás okaiként hasonló dolgokat emel ki, mint amelyek a nyugati buddhizmus történetének rövid leírásánál már szerepeltek. Ilyen a hétköznapi élet ridegsége és a kiúttalanság érzése, az érzelmi kielégületlenség, amire azonban a hagyományos vallási formák - különösen a tudományos világkép tükrében - nem adnak megfelelő választ. Tapasztalatai szerint a buddhizmus felé forduló emberek kulturális hátterére az jellemző, hogy a családjaik nem vagy legfeljebb formálisan vallásosak, és leginkább valamilyen körvonalazatlan szellemi érdeklődés vezeti őket a buddhizmushoz. Esetükben a buddhizmus nem is feltétlenül vallásként jelenik meg (a szó hagyományos értelmében), hanem inkább egyfajta életfilozófiaként vagy mentálhigiénés gyakorlatként. Ilyenkor maga a buddhista identitás is gyenge, illetve meglehetősen elmosódó határokkal rendelkezik. Ennek az „elmosódó identitásnak” viszont több formája létezik: kettős vallásosság, identitásnélküliség, valamint főleg régebben létezett a buddhizmus egyfajta hobbiként való felfogása. A buddhista közösségekre is jellemző ez a fajta „lazaság”, a szilárd határok hiánya, ami pedig Farkas szerint 
a karizmatikus vezetők hiányára vezethető vissza. „A buddhista közösségekben aránylag kicsi az összetartó erő, és eléggé nagy a fluktuáció. A legtöbb közösség egy viszonylag kis számú »kemény magból« és egy nagyobb számú, lazább (s nemegyszer szintén több kis körből álló) holdudvarból tevődik össze.” (Farkas [1998], pp. 38-43.) A gyenge kohézió oka az is, hogy a buddhizmus hazánkban (és valószínűleg az egész Nyugaton is) a hagyományos vallásosság (elsősorban a kereszténység) intellektuálisabb alternatívájaként jelent meg, amelyben a hittel szemben a filozofikus látásmód és annak megtapasztalása az elsődleges. ${ }^{46}$ Egy vallásos közösség számára azonban a vallásos hit jelenti a legnagyobb összetartó erőt. (Farkas [1998], p. 44.)

Kamarás István pedig a magyarországi, rendszerváltás utáni új vallási jelenségekkel kapcsolatban kiemeli a történelmi egyházak iránti bizalom csökkenését, amelynek három okát jelöli meg. Az egyik a velük szembeni túlzott (irreális) várakozás; a másik a sokaknak ellenszenves politikai elkötelezettség; a harmadik pedig az, hogy ezek az egyházak nem ápoltak megfelelő kapcsolatokat a társadalommal. „Gyakran idejétmúlt modellekhez nyúltak, nem ébredtek társadalmi-közéleti jelentőségük és szerepük tudatára, nem vállaltak súlyuknak és lehetőségeiknek megfelelő szerepet a civil társadalom építésében, nem foglalkoztak a legsúlyosabb társadalmi problémákkal, nem reagáltak eléggé érzékenyen az idők jeleire, és nagyon sokszor képtelen voltak a párbeszédre. Bizonyos értelemben igaz, hogy az új vallási áramlatokhoz tartozó csoportok, közösségek, mozgalmak és egyházak éppen a történelmi egyházak által elhagyott, elhanyagolt vagy el nem foglalt területeket hódították meg, az általuk nem vállalt feladatok megoldására

\footnotetext{
${ }^{46}$ Ezt támasztja alá az alábbi interjúrészlet is, amelyből ugyanakkor az is kiderül, hogy a Thich Nhat Hanh és a Szelíd Mosoly éppen azért vonzó a megkérdezett számára, mert megengedi ezt a látásmódot, és ez nem gyengítette, hanem ellenkezőleg, megerősítette az elkötelezettségét: „Én úgy gondolom, hogy a buddhizmus, az elejétől a végéig, függetlenül attól, hogy mahájána vagy hínajána vonulat, függetlenül a tradíció irányvonalától, időpontjától vagy végső céljától, nem tekinthető vallásnak. Inkább gondolom filozófiai irányzatnak vagy tudatkeresési módszernek, filozófiai gyakorlatnak, minthogy egy vallás lenne. Mint ahogy a japánok bebizonyították, akik szeretnek patchworköt csinálni a vallásokból. Ott náluk teljesen normális, hogy, mondjuk, valaki jezsuita, tiszta föld buddhista, sintoista meg zen buddhista egyszerre, és ezért tud múködni ez a dolog. Ez a megközelítés közelebb áll az abszolút igazsághoz, mintha az egyik kizárja a másikat. Szóval valószínűleg a nyelvi megközelítésünk nem jó, és ez nem egy vallás, hanem valami más dolog. A Szelíd Mosoly, a Thich Nhat Hanh tradíciója ezt erösítette bennem egyelöre, jelen pillanatban ebben az állapotban vagyok. Ez annyira komolynak vagy erôsnek bizonyult, hogy meg tudtam tartani a napi szintû́ gyakorlást, és ez elég fontos dolog." (Zsolt)
} 
vállalkoztak, az általuk meg nem válaszolt kérdésekre kínáltak (gyakran impozánsan egyszerű) válaszokat, az általuk nem (vagy nem megfelelően) megszólított rétegeket szólították meg." (Kamarás [2002], pp. 194-5.) A történelmi egyházak vonzerejének csökkenése tehát nem elvallástalanodást eredményezett, hanem a vallási szükségletek kielégítése új formában, a maga módján vallásosság keretében történik meg.

\subsection{Vallásosság a közösségben}

A korábbi fejezetekből láthattuk, hogy a buddhizmus esetében több olyan jellemzőt is kiemelhetünk, amelyek meglehetős szabadságot adnak a gyakorlása terén. Ilyen volt egyrészt az, hogy nagyon rugalmas, alkalmazkodó vallás, amely hajlandó tekintetbe venni az adott országban, földrajzi területen már meglévő vallási, világnézeti elveket és szokásokat, és engedményeket tenni olyan dolgokban, amelyek feltétlenül szükségesek a meghonosodásához. Másrészt kiderült, hogy a buddhizmus vallásként, filozófiaként, pszichológiaként vagy mentálhigiénés gyakorlatként is tekinthető és megélhető. Azt is láttuk, hogy a buddhizmus esetében nem jelenik meg egy olyan kizárólagossági igény, amely megnehezítené akár más vallások követői, akár a vallástalanok számára a bizonyos szintű bevonódást, a tan iránti érdeklődést. ${ }^{47}$

47 A szakirodalmon ugyan kívül esik, de jól mutatja a buddhizmus iránt érdeklődő személy perspektíváját Jorge Luis Borges egyik esszéje, amelyben az alábbiakat írja: a buddhizmus tartóssága történelmi okokkal magyarázható, de ezek az okok esetlegesek, vagyis inkább vitathatóak és nem csalhatatlanok. A tartósság két alapvető okra vezethető vissza. Egyrészt a buddhizmus toleranciájára, ami - más vallásokkal ellentétben - nem egy konkrét korszak sajátossága: a buddhizmus mindig is toleráns volt. Sohasem térített túzzel-vassal, sohasem gondolta, hogy ez megfelelő ösztönző lenne. Amikor Asóka, Kína uralkodója buddhista lett, nem akarta senkire sem rákényszeríteni új vallását. A jó buddhista lehet evangélikus, metodista, református, sintoista, taoista vagy katolikus; teljes szabadsággal áttérhet az iszlámra vagy a zsidó vallásra. Ugyanakkor egy keresztény, egy zsidó vagy egy muszlim számára nem megengedett a buddhistává válás.

Borges egy japán zen buddhista barátját idézi, aki szerint nem fontos hinni Buddha mint személy létezésében, hanem csak a Tan igazságában. Azzal a (Borges szerint inkább leleményes, mintsem igaz) hasonlattal világítja ezt meg, hogy az ezzel kapcsolatos hit olyan, mintha összekevernénk Pitagorasz vagy Newton életrajzát a matematika igazságával. A japán és kínai kolostorok szerzetesei például végeznek olyan meditációkat, amelyekben Buddha létezését kérdőjelezik meg. Ez a fajta kételkedés hozzásegít az igazság eléréséhez. Más vallások ezzel szemben sokkal erősebb hitet várnak el: a keresztényeknek hinniük kell abban, hogy a Szentháromság egyik személye leereszkedett az emberek közé, emberré vált, majd megfeszítették Júdeában. A muszlimoknak abban kell hinniük, 
A buddhizmus iránti világi elkötelezettség egészen különböző mértékű és típusú lehet. Előfordulhat, hogy valaki szinte egyáltalán nem foglalkozik a metafizikai felépítménnyel, vagy mert nem érdekli, vagy mert úgy érzi, képtelen azt megérteni, ugyanakkor magáévá teszi a buddhizmus morális elveit, és/vagy végzi a meditációs és más technikákat. Mások kifejezetten intellektuális érdeklődéssel fordulnak a buddhizmus felé. A vizsgált közösségben gyakorlatilag a világi érdeklődés teljes spektruma fellelhető (ebből esetenként konfliktusok is adódnak), és ugyanez a sokszínűség igaz a más vallásokkal kapcsolatos háttér vagy viszony terén is (ami az érdeklődéssel ellentétben problémamentes). Mindazonáltal felfedezhetők bizonyos olyan közös vonások, amelyekből általános következtetéseket vonhatunk le. A következőkben e sokszínűség és a közös jellemzők bemutatására kerül sor interjúrészletek segítségével.

Az interjúkérdések egyik csoportja a korábbi és jelenlegi vallásosságra vonatkozott. A válaszok sokfélék voltak mind a korábbi vallásosság, mind a bejárt út, mind pedig a jelenlegi vallásgyakorlás tekintetében. Az általánosan elmondható, hogy bizonyos szintű nyitottság mindenkiben megvan, de a más vallások elutasítása tekintetében egészen eltérő álláspontokat fogalmaztak meg a megkérdezettek. Többször visszatérő elem volt az egyháztól mint intézménytől való távolságtartás, a fanatizmus, dogmatizmus kerülése, és különösen nagy hangsúlyt kapott a szabadság igénye - az gyakorlatilag minden megkérdezettről elmondható, hogy fontos számukra az autonóm gondolkodás, és nem várják azt, hogy egyetlen vallás vagy eszmerendszer választ adjon minden kérdésükre. Nincs meg bennük az igény arra, hogy elköteleződjenek egyetlen rendszer mellett, ami nemcsak a vallási vagy világnézeti kérdésekre igaz, hanem gyakorta megjelenik a munkájukban is.

A korábbi vallásosság és a buddhizmus felé fordulás tekintetében többféle út rajzolódott ki. Voltak, akik olvasmányélmények révén, intellektuális érdeklődésből

\footnotetext{
hogy egy Isten van, Allah, és Mohamed az ő prófétája. Jó buddhisták azonban úgy is lehetünk, ha tagadjuk Buddha létezését - pontosabban fontosabb a Tanban hinnünk, mint a történelmi eseményekben. (Borges [2009], pp. 58-60.) Borges meglátásaival kapcsolatban azonban egyrészt meg kell jegyezni azt, hogy vannak olyan vélemények is, amelyek szerint a buddhizmus nem a toleranciája miatt tudott könnyen elterjedni, hanem a tanainak homályossága és az ebből fakadó széles értelmezési tartomány miatt. Másrészt Bauberger és Johnston írásaiból láthattuk, hogy a keresztények számára is alkalmas lehet pl. a buddhista meditáció gyakorlása, amit persze nem kell „buddhistává válásnak” tekinteni. Harmadszor ha valaki elkötelezi magát a buddhista út mellett, akkor a három ékkőben vesz menedéket, amelyek egyike a Buddha. Buddha létezésének megkérdőjelezése inkább egy olyan technika, amely hozzásegít a pradnyá eléréséhez.
} 
találkoztak először a buddhizmussal, illetve más vallásokkal. Voltak, akik tanáraiktól hallottak először a buddhista tanról, mások pedig valamilyen önismereti úton jutottak el hozzá. Olyan is volt, aki először a közösségbe került be, és a tanításokkal csak ott találkozott, korábban semmiféle tapasztalata nem volt a témában. A más vallási háttér tekintetében az ateizmus, a katolikus és zsidó identitás egyaránt felmerült. A kereszténység jellemzően a kultúra vagy a szocializáció részeként, spirituális gyökérként, a fiatalkori útkeresés egyik állomásaként, illetve egy jövőbeli „megérkezés” lehetőségeként jelenik meg. A zsidóság esetében a szocializáció és az útkeresés aspektusa mellett leginkább a közösség szerepét emelték ki a megkérdezettek. Pozitívumként mindkettőnél főleg az alaptanítások és a spiritualitás került elő, negatívumként pedig a kizárólagosság és az egyházi szervezet. A kereszténység és a zsidóság mellett felbukkant például a hinduizmus is, ez azonban minden esetben már a felnőttkori intellektuális érdeklődéshez kapcsolódóan. ${ }^{48}$

$\mathrm{Az}$ alábbi megkérdezettek keresztény háttérrel rendelkeznek, azonban mindegyikükről elmondható, hogy nem az intézményes vallást keresik, inkább érzelmi, spirituális gyökérnek, fogódzónak tekintik azt. Nem jelent számukra problémát a különböző vallásos tanok összeegyeztetése, és bizonyos résztvevők attitűdje leírható a Campbell által is említett „útkereső” fogalommal. Ez azonban mindenképpen magában foglal bizonyos általánosítást ${ }^{49}$, és azt is meg kell jegyezni, hogy számos megkérdezettnél inkább az mutatkozott meg, hogy útkeresők voltak, akik azonban már hazaérkeztek.

„Nagyon mélyen nem tanulmányoztam más vallásokat, de keresztényként nöttem fel, jártam hittanra, a hinduizmusról is valamennyire tudok, meg a kurzuson végigvették az összes keleti vallást. (...) Néha elmegyek templomba, és ha Istenről van szó, akkor a keresztény Istenhez viszonyulok valamennyire, de annyira nem vagyok istenes. Nem probléma összeegyeztetni, bármilyen istennel összeegyeztethető a buddhizmus. Nekem nagyon fontos a rugalmassága, ugyanakkor a hitelességét az adja, hogy van egy nagyon kemény történelmi mag és hagyomány. [A nyugati buddhizmust] nagyon jónak tartom, nem is lennék máshogy buddhista, egyértelműen az amerikai buddhizmushoz kezdtem kapcsolódni." (Boglárka)

\footnotetext{
${ }^{48}$ Az elemzésekben szereplő szempontok az idézetekben dőlt betűvel vannak kiemelve.

${ }^{49} \mathrm{Pl}$. egyikük önmagát nem tartja igazán kereső típusnak, de az új hatásokra való nyitottság benne is megvan, egy másik megkérdezett pedig azt mondta, hogy a közösség tagjait kifejezetten nem tartja útkeresőnek, ami nagyon szimpatikus a számára.
} 
„Úgy gondolom, hogy az embernek van egyfajta spirituális gyökere, akár él vele, akár nem, akár vallásos, akár nem, és csak ez lehet igazán az övé. Magamnál úgy gondoltam, hogy csak egy felvett póz lenne, ha olyat vennék fel, ami nem kapcsolódik a gyökereimhez. Ha valahol őszintén akarom keresni, akkor az én gyökerem a katolikus valláshoz kapcsolódik, de nem a klerikalizált formájához, hanem az Ó- és Újszövetséghez. De ezt sem gyakorlom igazán, a hétköznapokban legalábbis nem. Katolikusnak tartom magam, ezt hoztam von haus. Minek váltani? Ha nem járok templomba, nem érdekel az egyház, a papok, de van saját kapcsolatom azzal a mindenhatóval vagy segítővel vagy bármivel, akivel kötésben vagyok, ugyanúgy lehetek katolikus alapon is. De pap nélkül mindenképpen, az nekem nem kell, mert mindegyik isten ugyanaz, még akkor is, ha amikor lefordítják háborús helyzetekre, akkor egymást kinyírják, mert az enyémnek ilyen a szakálla, a másikét meg nem lehet lerajzolni, pedig ugyanolyanok." (Erzsébet)

„Akkor kerültem a katolicizmussal kapcsolatba, amikor felkerültem Budapestre és egyetemista lettem, mert egy olyan lánynál laktam albérletben, aki katolikus volt, és akkor voltak ezek a kis katolikus körök, és mivel ott laktam, hát beültem. Ez jó volt, mert igerészeket beszéltünk meg, és ez megint egy ilyen érzelmi alapú közelítés volt. Aztán bekerültem egy ökumenikus csapatba, azzal is az volt a bajom, hogy akkor is azt szúrtam ki - ez is ilyen elvonulásszerű volt -, hogy mindenki milyen jó, amíg ott van, ott mindenki nagyon jó akar lenni, és én azt éreztem magamban, hogy de hát oké, ilyen is vagyok, de nemcsak ilyen vagyok. Akkor elkezdtem reformátusokhoz járni, mert én ezt a gyónás cuccot, ezt nagyon nem [szeretem]. Ezeken a vonalakon inkább szellemi hatások voltak, bizonyos tanok, beszélgettünk a hitről meg ilyesmi. Akkor a Szabó Istvánhoz jártunk, oda nagyon sok fiatal járt, és abban az időszakban jártam misékre, istentiszteletre, és totálisan nem zavart ez. Elötte én abszolút nem kaptam vallásos nevelést, de voltak megéléseim, amik arra vonatkoztak - annak ellenére, hogy teljesen racionális vagyok -, hogy jó-jó, de én ezt nem tapasztalhatom meg, ha az anyagi világon túl nincs valami más. (...) A buddhizmusról voltak körülbelüli fogalmaim, hogy körülbelül mit mond, de igazából nem is érdekelt. Egyébként mindig azt tapasztalom, hogy alapjaiban az, amit én a világról gondoltam, vagy ahogy gondolkodtam emberekről meg kapcsolatokról meg hitről, tehát az, ami volt az egyik pontodban, hogy ez ütközik-e valamivel abból, amit én hiszek, vagy fölmerül-e az, hogy ha a Jóistenre gondolok, ez sose volt. És mindig kicsit csodálkozom is, amikor jöttek ilyen kérdések azoktól, akik nagyon vallásosak voltak, hogy akkor ez most hogy összeegyeztethetô, de nekem meg ez fel nem merül, nem is értem. Thich Nhat Hanh-tól azt a két könyvet olvastam, mást meg annyira nem, hanem úgy meghallgattam ezeket a tanításokat, és köszönöm szépen, én ezzel jól elvagyok. De nem mentem soha semmilyen más buddhista tanítóhoz, nem olvastam Dalai Lámát, nincs összehasonlítási alapom. Úgy fogalmaznám meg, hogy amivel nekem találkoznom kell, az majd jön. Nem feltétlenül vagyok egy ilyen kereső, hanem úgy bejönnek hatások, és akkor megnézem, hogy az mi. Valamiben megragadok, valamiben meg nem. Ebben megragadtam." (Judit) 
A következő megkérdezett szintén katolikus háttérrel rendelkezik, és a katolikus útkeresése után jutott el ahhoz az általa autonóm vallásosságként ${ }^{50}$ definiált állapothoz, amelyet az alábbi módon jellemzett:

„Nekem a buddhizmus nem felülről induló történet, hanem a saját életem élésében szerettem volna, nemcsak hogy én kevesebbet szenvedjek, hanem a lányaim is, és szerettem volna saját magamon belül is eljutni azokhoz a pontokhoz, amikkel szenvedést okozok nekik. Tudtam, hogy nem tudom megkímélni őket, de mégis, amennyire lehet. A saját bugyraim mentém talán eljutottam oda, ahol közösek vagyunk mindannyian, a buddhizmus, a katolikus út, nagyon sokféle út találkozópontjához. Nem tudok mit kezdeni egy elméleti buddhizmussal. Az életemből indulok ki, és az életemhez találok olyan pontokat, amik segítenek élni. És akkor azt mondják, hogy ez egy buddhista gondolat, de ez engem nem érdekel, bocs. Ha ezt éppen nem Buddha mondta, hanem Jézus mondta, akkor az is rendben van. Nem Buddhának akarok hódolni meg Jézusnak akarok hódolni, hanem élni szeretnék együtt a többi emberrel, és én is emberséges szeretnék lenni. És hogyha ehhez Buddha gondolatai járulnak hozzá, ami bennem gyökeret ver, akkor az járult hozzá." (Eszter)

Van olyan is, aki úgy látja, hogy a buddhizmussal való foglalkozás hosszabb távon visszavezetheti keresztény gyökereihez.

„Vallásosnak nem tartom magam, de nagyon erősen spirituálisnak igen. Meg ugye a saját kapcsolatomat a saját létezésemmel meg a tudatossággal meg a világegyetemmel folyamatosan próbálom megélni különböző szinteken, az nagyon jellemző rám. De úgy vallásos hétköznapi értelemben nem - hát szívesen lennék, de abban nagyon sok olyan gyakorlat van, ami nem tudatos, szóval hogy akkor egy közösség tagja vagyok, a többiek kívül vannak. Van egy határ, amin belül vagyunk mi, vannak a szokásaink, az a helyes. Ez a vallásosság? A sváb gyökerek megvannak, a katolikus, meg erős református hatás. A buddhizmusban az is segít, hogy hozzásegít a katolicizmushoz való közeledésemhez szerintem. Fölmerült bennem, hogy ha az őseimnek az volt a vallása, akkor miért ne vehetném föl, de úgy nagyon nem volt erős a késztetés. De [a buddhizmus] segít az erre való ráhangolódásban, hogy az maradjon meg, amihez nyugodt szívvel tudok csatlakozni." (Gábor)

A megkérdezettek egy másik csoportja kifejezetten a korábbi vallástalanságát hangsúlyozta, és náluk egyértelműen megmutatkozott az erőteljes intellektuális érdeklődés is.

„20 éves koromig teljesen ateista voltam, utána kezdtem vallásokkal foglalkozni. Sose voltam vallásos, vagyis azt is mondhatom, hogy vallásos vagyok, de nem tradicionalista. Azon belül is buddhista, de nem a tradicionalizmus alapján,

50 Több szerzőre is hivatkozott ezzel kapcsolatban, így pl. Scott Peck $A$ járatlan út c. könyvére, valamint Anselm Grün bencés szerzetes alulról induló lelkiséggel kapcsolatos gondolataira. 
hanem a Buddha tanításai alapján. [A tradicionalizmus] van, akinek bejön, az látszik, de a saját életemet nem gondolom, hogy tradíció alapján kéne berendeznem. De csomó elemet használok az életemben, amit Thich Nhat Hanhtól tanultam, de más vallásoktól is, a kereszténységtôl, a hindu vallástól, a buddhizmustól - ezek azok, amikkel sokat foglalkoztam. Az alaptanításaik számomra meggyőzőek, amiket ezek a nagy mesterek, szentek, maguk az alapítók mondtak. Thich Nhat Hanh-t is ezek közé sorolom, meg az olyan okos embereket is, mint Jan, akitől sokat tanultam. Ő se tradicionalista, a dolgok lényegéről beszél, nem arról, mit kell követnünk. Az, hogy összeszedegetem [a különböző tanokat], egy nagy szellemi kaland." (Péter)

„[A buddhizmussal való találkozásom] nagyon lassan zajló folyamat volt, először Indiában [kerültem kapcsolatba vele] 30 éve, de akkor csak azt éltem meg, hogy nagyon szimpatikus az indiai hozzáállás a dolgokhoz, ahogy kezelik egymást, meg nem láttam erőszakot, de ezt akkor csak elraktároztam magamban. Akkor nagyon sok bajom volt az emberekkel, azt gondoltam, bennem van a hiba, de ott tudtam szeretni embereket. És ez így bennem maradt, hogy ők máshogy viselkednek, nem minden a pénzrôl szól, hanem hogy mindenkinek jusson, meg egyáltalán az élet tisztelete. Akkor bekattant, hogy a hinduizmus meg a buddhizmus mások, más az életszemlélet. Utána amikor Amerikában éltem, (...) láttam egy hirdetést, ingyen meditációoktatás, relaxáció, és arra elmentem. Közben már intellektuálisan érdekelt a buddhizmus, mert azt éreztem, hogy a természettudományok már nem elégítenek ki intellektuálisan, és mivel a Columbián dolgoztam, lehetett venni minden félévben ingyen egy órát. Elkezdtem ilyen órákat venni, hogy keleti vallástörténet, intellektuálisan ezek nagyon szimpatikusak voltak. (...) A kettő így összekattant, amikor elkezdtem meditálni, amit megéltem meditálás közben, meg amit a buddhisták mondanak, amit olvastam. Nem volt semmi megélni azt, hogy változom, olyannyira megéltem, hogy meg is változtatta az életemet ez akkor."51 (Boglárka)

„Nem voltam vallásos korábban, de a buddhizmus rengeteg választ ad a kérdéseimre. A tanító [egy másik közösségben] mondta, hogy sokan izgulnak azon, hogy van egy vallásuk, és akkor probléma lehet, hogy meditálnak. De ez nincs így, összeegyeztethetôk." (Balázs)

„Nem voltam vallásos korábban. Nagyanyám szerette volna, ha jó keresztény vagyok, vitt templomba, de halálosan untam, hidegen hagyott. Sokszor mentem keresztény templomba, de inkább mint kulturális élményt tekintem, érdekel mint a kultúra része, de nem mint vallás. Most sokat járok zsinagógába, de ott se a vallás érdekel, hanem a kultúra és a közösség, a tartozás valahova. A buddhizmus iránti érdeklődésemre ezeknek nem volt hatása." (Ádám)

51 Továbbá: „Belecsöppentem egy másik csoportba is, ahol a mester egy hindu volt, de teljesen vallástól független volt. Abba a szanghába jártam, meg pl. a New York-i szangha vezetője egy zsidó volt. Volt ott minden, csak épp muszlim nem, de nem tudom, az eredeti vallásukat mennyire úzték ezek az emberek." 
Ezek az idézetek számos olyan elemet tartalmaznak, amelyek korábban a különféle értelmezési lehetőségeknél már előkerültek: a vallás kultúraként való felfogását, a hozott vallás és a meditáció összeegyeztethetőségét, a nyugati problémákra adott társadalmi és tudományos válaszok elégtelenségének érzését, a kevésbé materialista keleti világnézet vonzóságát, a különféle nézetekből alkotott egyéni világképet, egyúttal az igényt az „alapokhoz” való visszatérésre. A következő interjúban megjelenik még az a nyugati buddhizmus kialakulásában szintén fontosnak tartott elem, hogy a keresztény tanításban való hit a tudományos világkép térhódításával megrendült. A megkérdezettek számára fontos az, hogy a tanítást össze tudják egyeztetni azzal, amit racionálisan gondolnak a világról.

„Amikor 12 éves voltam, akkor megjelent a hittanóra az iskolában, és érdekelt, elmentem és teljesen beszippantott, pedig ateista családból származom. (...) Rögtön apáca akartam lenni, annyira megfogott, és megkereszteltek, amikor 14 éves voltam, majd utána történt valami, ami miatt abbahagytam. Akkor viszont tényleg érdekeltek a filozófiák, összeolvastam mindent, és teljesen összeveszett bennem az, amit racionálisan gondoltam a világról, és amit a katolikus hittanon tanítottak, és egy totális ellentmondást találtam. Abban találtam meg a megoldást, hogy teljesen abbahagytam a templomba járást. Néha most is elmegyek karácsonyi misére, halottak napján, de már nem jó érzés. Mindig várok valamit, meg szeretem a Bibliából az idézeteket, de ha valami vonalas szöveg jön utána, attól rosszul vagyok, tehát attól függ, hogy milyen a pap. Azóta csak a katolikusság bírálata jött vissza, de a mostani pápát nagyon bírom. Most már a Bibliával is bajom van, konkrétan azzal, hogy »Én vagyok az út, az igazság és az élet«, totálisan kizárólagos. Ez az, ami a buddhizmusban nincs meg." (Nikolett)

„Most nem tudom, hogy ebben pont hol vagyok, csak azt gondolom, hogy a buddhizmus meg amit más vallásokból [kapok], és mindegy, hogy Istennek hívom, vagy mi az a rend, ami körülöttünk van, azt én elfogadom, hogy van. És mivel nem tudom a keresztény vallásoknak ezt a büntető istenét befogadni, ezért azt gondolom, hogy a buddhizmusnak ez a fajta semlegessége, hogy nem vagyok bűnös, tehát hogy odateszi a jót-rosszat, de azt mondja, hogy ez így együtt van, és önmagában véve nem kívülről fogja megítélni valaki, hogy te mi vagy és mit csinálsz, hanem az úgy egyben van, ettől nekem valahogy sokkal jobban egyberakható. Attól én még érzem az ő szabályszerűségét vagy nagyságát benne a világban, mert mozog körülöttem, és megvannak a szabályszerüségei. Ha nincs sár, nincs lótusz, vagy hogy a pusztulás és lebomlás nélkül nem lehetne új élet. Ezek valahogy szervesen egyben vannak. Mintha a személyes Istent az a gondolat vette volna át, hogy nem is az, hogy valaki vigyáz rám, hanem hogy ennek itt valahogy része vagyok." (Judit) 
Az utóbbi két sorban kifejezetten a Campbell által a transzcendens és az immanens vonatkozásában megfogalmazott gondolatok tükröződnek. A terepmunka során ez a hangsúlyeltolódás többször is előkerült - bár láthattuk, hogy e nézet kritizálható (pl. azzal, hogy a keleti vallásoknál ez a fajta immanencia inkább az értelmiségiek és vallási virtuózok filozofikus, doktrinális vallására jellemző), mégis ez a gondolatiság tetten érhető az interjúkban. Végül pedig olyan vélemények következnek, amelyek radikálisan elutasítják a vallás intézményes formáját.

„Én azt látom, hogy a vallásoknak mindig is az volt a nagy veszélye, hogy egész egyszerűen a test nincs a helyén. A legtöbb vallásnál az istenélményhez, a megérintettséghez való eljutáshoz valamilyen testi lemondáson, aszkézisen keresztül vezet az út. És valamelyik ezt piedesztálra emeli, Indiában van egy olyan szekta, amelyik kimondottan megmondja a tagoknak, hogy ha te jössz, akkor a testedet adod nekem, és akkor bármilyen rendû-rangú nő ezt el is fogadja abban a helyzetben, és ez alapvetően arról szól, hogy kihasználom a másikat. Erre nincs szükség, el lehet érni az istenélményhez úgy is, vagy ehhez az egységélményhez, hogy nem tagadom meg a testemet. Könnyebb, ha megtagadom, de erre nincs szükség, azt gondolom, hogy ez egy tévút. Én ezért három lépés távolságban bírok lenni a vallástól, és inkább a spiritualitást gyakorlom, merthogy a fordítás, már maga az ige megöli az üzenetet. Szerintem ha az ige papírra kerül, onnantól kezdve elvész már többnyire, és erre azért soksok példa van. Ha visszamászok a legelső iratig, akkor nyomon lehet követni a fordítási hibákat, de mert úgy lett kanonizálva, mert marha nagy szégyen lett, hogy valaki elírt egy i betűt, onnantól kezdve már nem lehet kijavítani, és akkor az írott szó válik hitté, üresen. Mint ahogy mutatja ezt a hívők gyakorlása, akik gyakorolnak, gyakorolnak, csak hát nem megy, mert nem az van. És a buddhizmus ebből a szempontból rendkívül pragmatikus. Tehát gyakorolom, gyakorolom, és közben egyre jobban változtatom az igét, hogy az letükrözze a gyakorlásomat. A buddhizmus annyira nem érdekel, nekem ez [csak kimondottan] a zen. Nem vallás." (Márton)

„Mit értünk vallásosságon? Hiszek Isten létezésében, számomra nem az a vallásosság, hogy valamilyen templomba elmegyek, és ott imádkozom, meg mindig megyek. A hivatalos egyházak által képviseltet nem tartom jónak, mert ezt a világ legjobb MLM-rendszerének tartom. A bűn-érzésre alapozza, öljél meg bárkit, de ha holnap behozol egy kis lóvét, akkor feloldozunk. »Árulj bűnoldó papi bullát«52." (László)

„Ami problémás, a vallás maga mint kategória. Nem tudok amellett elmenni, hogy hány millió embert öltek meg valami vallás zászlaja alatt. Amellett, hogy nagyon érdekel kisgyerekkorom óta, a vallásfogalmakkal problémám van. Ebben most már nincs feszültség, ha egyszer muszáj lenne kimondani, hogy

${ }^{52}$ François Villon Jó tanítás balladája a rossz életǔeknek című költeményének első sora. 
vallásos vagy, mert jönne valami nagy ember, akkor azt mondanám buddhista vagyok. Sokkal könnyebben mondanám, mint mást." (Viktória)

Következtetésként az vonható le ezekből az interjúkból, hogy a megkérdezettek nem rendelkeznek kifejezetten vallásos családi háttérrel, így jelentős szabadságuk volt és van a számukra megfelelő út megtalálásában, és hajlandóak is kísérletezni. Az, hogy egyáltalán vallásosnak tekinthetők-e, alapvetően definíciós kérdés: a klasszikus meghatározások szerint inkább nem vallásosak (hanem a Tweed által megadott értelemben szimpatizánsok), azonban a James-féle értelmezésben, vagyis ha az intézményes vallásosság helyett a személyes élményt helyezzük a középpontba, és vallásnak az egyén azon magányosan megélt érzéseit, tetteit és tapasztalatait tekintjük, amelyek kapcsolatban állnak az általa isteninek tekintett dologgal, egy részük vallásosnak tekinthető. Ebben az értelemben illeszkednek a modern társadalomban megfigyelhető azon jelenséghez, hogy az egyház rendjéhez igazodó vallásosság mellett és helyett a „maga módján vallásosság” nyer teret. (Ez a jelenség Magyarországon a 70-es évek óta ismert.) Tomka hangsúlyozza, hogy ezt tévedés lenne az egyház és az egyháziasság tudatos elutasításával azonosítani (bár láttuk, hogy a megkérdezettek körében erre is vannak példák), hiszen az így jellemezhető emberek tudatosan merítenek a keresztény hagyományból (amit szintén láthattunk). Erre a típusra jellemző a vallásos hit gyengülése és ellentmondásossá válása, a vallásgyakorlat ritkulása, az egyházi kapcsolatok felszámolódása (Tomka [2010], pp. 404-5.). A jelen kutatás eredményei mind összhangban vannak ezekkel a megállapításokkal.

\subsection{Nyelv és megértés}

Ebben fejezetben néhány nyelvvel kapcsolatos megfontolásról esik szó a bevezetőben már említett okból, vagyis hogy a vizsgált színtér többnyelvű, az érintett vallás szövegei pedig eredetileg páli, szanszkrit, illetve más távol-keleti nyelvűek. E többnyelvűség felveti a megértés és az értelmezés kérdését mind a vallás irodalma, mind a szertartások és az élőbeszédben (tolmácsolással) átadott tanítások szempontjából. Különösen, ha úgy tekintjük az embert, mint az egyetlen olyan élőlényt, amely - a beszéd, a szimbólumhasználat, a gondolatok, érzések, vágyak és magatartási módok közlésének képessége, a kultúrája hagyományainak, 
babonáinak és ismereteinek birtokában levés miatt - valóban képes a megértésre és félreértésre. (Black [1998], pp. 9-10.)

A nyelvet tehát a kommunikáció egyik intézményeként veszem, amelynek „a gondolkodásban, a világ reprezentációjában, rendszerezésében aktív szerepet tulajdonítunk. Az intézmény adja azt a szignifikációs alapot, amelynek segítségével írott vagy hangzó szignifikánsokkal a körülöttünk levő világ (beleértve az ágens sajátvilágát is) valamely része vagy teljes egésze szignifikálható mint szignifikátum. Az ágens számára ennek a nyelvben rögzített világnak az elérésére van mód, ezt hagyományosan a nyelvi kategorizáció és a gondolkodás összefüggéseként tárgyalják. Az ágens a világot ugyanis az általa elérhető, hozzáférhető nyelvi kategóriáknak megfelelően észleli, ezekben gondolkodik róla" (Pete-P. Szilczl [2006] p.59.). Black úgy fogalmazza meg, hogy a nyelv intézmény, mert az individuális beszélő mögött ott van a nyelvközösség annak szilárd hagyományaival és életmódközösségével. Nézőponttól függően a nyelv tekinthető az egyik legmerevebb, de az egyik leghajlékonyabb emberi intézménynek is, amennyiben egyrészről ott vannak a nyelvi megnyilatkozás látszólag rugalmatlan szabályai, másrészt pedig az ettől való megszámlálhatatlan individuális eltérés. (Black [1998], pp. 63-4.)

E meghatározás nyomán felmerül az a kérdés (mint ahogy korábban a kultúra kapcsán is), hogy a nyelv mennyiben határozza meg az ágens gondolkodását, tehát a különféle nyelvek különböző gondolkodásmódokat takarnak-e, vagy maga a gondolkodás nyelvtől függetlenül egyetemes, és az egyes nyelvek egyszerűen csak variációk egy témára?53 Az első álláspontot nyelvi relativizmusnak, a másodikat pedig nyelvi univerzalizmusnak nevezzük. E kettő közül a relativista felfogás a közismertebb, mint ahogy Pléh Csaba említi, olyannyira, hogy „sokszor még olyan pars pro toto helyzet is megjelenik, mintha maga a gondolkodás-nyelv kérdés egésze abban merülne ki, hogy másként gondolkodnak-e eltérő nyelvek beszélői”. (Pléh [1999], p. 45.)

\footnotetext{
53 Illetve a kérdés fordítva is felmerül, vagyis hogy a gondolkodás meghatározza-e a nyelvet. E tekintetben két felfogásról beszélhetünk, a kognitív relativizmusról és a kognitív univerzalizmusról. Az előbbi szerint a nyelvek eltérései a tapasztalati és kulturális különbségeknek tudhatók be, a kognitív univerzalizmus szerint pedig az érzékelési-megismerési folyamatok egyetemesek, és vannak olyan nyelvi univerzálék, amelyek kognitív univerzálékra vezethetők vissza. Tárgyunk szempontjából ez a dimenzió azonban kevésbé releváns.
} 
A relativista tézis tehát azt mondja, hogy a nyelvek eltérései gondolkodásmódok eltéréseit tükrözik. Pléh szerint ezzel a felfogással kapcsolatban az átfogó probléma az, „hogy amikor bizonyítani próbálják, nehéz eldönteni, hogy a nyelv, a természeti környezet vagy pedig a tárgyi világ és a kultúra eltérései adják-e a kiinduló mozzanatokat". (Pléh [1999], p.46.) Neumer Katalin kifejezetten a nyelven kívüli tényezőkre kérdez rá egy ponton. Hangsúlyozza, hogy nem új gondolat az, miszerint a nyelvi megértés és a beszéd nemcsak szókincset, valamint a szintaktikai és szemantikai szabályok elsajátítását kívánja meg, hanem bizonyos nyelven kívüli tényezőket - például gesztusokat, cselekvéseket, életformát, kultúrát, tradíciót és a fizikai világ tárgyait - is figyelembe kell vennünk. Ezenkívül az sem új gondolat, hogy számunkra a világ csak egy tág értelemben vett, az egész környezetével összeszövődött nyelv szemüvegén keresztül jelenik meg. Az a kérdés azonban eddig nyitva maradt, hogy milyen szerepük van ezeknek a nyelven kívüli tényezőknek. (Neumer [1999], pp. 27-8.)

A relativista felfogás egyik ismert és érdekes képviselője, Benjamin Lee Whorf szerint az ember az elképzeléseit a minden nyelv mögött meghúzódó nyelvi rendszer segítségével önti hangokba, sőt, inkább maga ez a rendszer önti formába az elképzeléseket. Ez a formába öntés nem egy független folyamat, hanem egy sajátos nyelvtani rendszer része, és a különböző nyelvekben többé-kevésbé eltérő módon megy végbe. Amikor a természetet, a jelenségvilágot kategorizáljuk, nem valamilyen meglévő típusokat ismerünk fel, hanem az elménkben meglévő nyelvi rendszerek segítségével hajtjuk végre a kaleidoszkópszerű benyomások összerendezését. ${ }^{54}$ A dolgoknak azért tulajdonítunk jelentést, mert részesei vagyunk annak a megegyezésnek, hogy így járjunk el. Ez a megegyezés az egész beszédközösségre érvényes, kötelező erejű. ${ }^{55}$ (Hivatkozza Black [1998], p. 74.)

${ }^{54}$ Egy számunkra meglepőnek tûnő példa a Borges által is említett, $A$ jóravaló ismeretek égi gyưjteménye című kínai enciklopédiában található osztályozás. Eszerint „az állatok lehetnek a) a Császár állatai, b) balzsamozottak, c) idomítottak, d) malacok; e) szirének, f) mesebeliek, g) kóbor kutyák, h) olyanok, amelyek ebben az osztályozásban szerepelnek, i) őrülten rázkódók, j) megszámlálhatatlanok, k) olyanok, akiket a legfinomabb teveszőr ecsettel festettek, l) másfajták, m) olyanok, akik az imént törtek össze egy vázát, $n$ ) olyanok, akik távolról légynek tûnnek". (Borges [1999], p. 279.)

55 Whorf az elméletére bizonyítékul a hopi indiánok nyelvét hozza fel. Leírása szerint a hopik a valóságot eseményekből állónak képzelik el, és az eseményeket a körvonal, szín és mozgás típusa szerint azonosítják. Nem hangsúlyozzák az időbeli viszonyokat úgy, mint az európaiak, nem állapítanak meg számunkra megszokott különbségeket tér és idő között. Ehelyett két nagy kategóriát 
Az univerzalista tézis szerint ezzel szemben a nyelvek nem is térnek el annyira egymástól. Humboldt azt mondja, hogy a nyelvek „változatok egy témára”, Jerry Alan Fodor pedig azt feltételezi, hogy mivel egy nyelv megértéséhez mindig szükségünk van egy másik nyelvi szimbólumrendszerre, lennie kell egy végső nyelvnek, amely valahogyan az idegrendszer szerveződésében kódolódott: ez „az elme nyelve”. Fodor azzal kritizálja a relativista felfogást, hogy az a gondolat, miszerint a kogníció átitatja az észlelést, összetartozik azzal a tudományfilozófiai ideával, amely szerint az elméleteink átfogóan megszabják megfigyeléseinket; azzal az antropológiai elképzeléssel, hogy értékeinket egészében a kultúránk határozza meg; azzal a szociológiai gondolattal, hogy episztemológiai elkötelezettségeinket (ideértve a tudományt) az osztályhelyzetünk determinálja; és azzal a nyelvészeti ideával, hogy metafizikánkat a szintaxisunk határozza meg. (Hivatkozza Pléh [1999], pp. 43-8.)56

E felfogások vitájában ugyan még nem sikerült dűlőre jutni, de Pléh egy mérsékelt relativista (vagy más szóval ironikus univerzalista) megközelítést javasol, amely elfogadja, hogy vannak bizonyos eltérések a nyelvek és kultúrák között, ezek azonban nem jelentenek valamiféle végső akadályt. Az egyedi emberek lehetőségei, a kognitív erőforrások egyetemesek, a különböző kultúrák azonban eltérő hangsúlyt helyeznek arra, hogy e forrásokat bármilyen helyzetben használni tudjuk. Döntő változás csak az írásbeliséggel lép fel, amikor megtanuljuk a dekontextualizációt, vagyis hogy elvont kognitív erőforrásainkat bármilyen helyzetben felhasználjuk, ami formálisabb gondolkodást jelent. De gondolkodásunk és érzésvilágunk alapjaiban, emberi lényekként egyetemesek vagyunk. (Pléh [1999], pp. 141-6.) E felfogás tárgyunk szempontjából is plauzibilisnek látszik, így a dolgozat további fejtegetései e megközelítés talaján fognak állni nemcsak a nyelvi, hanem a kulturális

alkalmaznak, ami nagyjából a szubjektívnek és az objektívnek felel meg. A szubjektív birodalom a még nem megvalósultat, a jövőt tartalmazza, és ezt a természeti jelenségekkel, az állati és emberi viselkedéssel kapcsolatos „rügyező" és „erjedő” tevékenységek spirituális birodalmaként fogják fel. Az objektív pedig ezen egyetemes pszichikus tevékenységnek a múltban és a jövőben változatlan készletű raktára. (Black [1998], pp. 63-4.)

${ }^{56}$ Van még egy olyan álláspont is ezek mellett - Lévi-Straussé -, hogy ez az egész kérdésfelvetés egy torz módon absztrahált, akadémikus kérdés, és a gondolkodás és a nyelv viszonya helyett az emberi viszonyok és a társalgási viszonyok összefüggése fogja alakítani jelzés és megismerés kapcsolatát. Eszerint az emberré válás során a kategorizáció megjelenése és állandósulása elsődlegesen nem nyelvi és nem is kognitív lépés, hanem az emberi társas kapcsolatok rendezésének igényéből fakad. (Pléh [1999], p. 49.) 
meghatározottság tekintetében is. A kérdés kibontásához az első állomás két buddhista alapfogalom jelentéseinek bemutatása lesz.

\subsubsection{Az együttérzés, szerető kedvesség és szeretet fogalma}

Ez a fejezet a buddhizmus két alapvető fogalmát - maitrī és karunā - tárgyalja. A fejezet célja annak bemutatása, milyen széles jelentéstartománnyal rendelkeznek ezek a kifejezések, amelyek eredetileg külön fogalmak voltak, de az idők során egyre inkább egymás kiegészítőivé váltak, és hogy csak hiányos ismeretet kapunk róluk abban az esetben, ha nem fordítunk figyelmet a teljes jelentéstartományukra. Ugyanakkor ez az akadémikus jellegű vizsgálatoknál és a buddhizmus iránti erőteljes intellektuális elkötelezettség esetén jelentkezik csak elvárásként, a gyakorláshoz elegendő lehet az egyszavas bevett fordítások használata: ugyanis a meditációban és más gyakorlatokban való elmélyülés, a szertartásokon való részvétel lehetőséget teremt a fogalmak által kifejezett érzések, értékek, szemlélet közvetlen megtapasztalására, a velük kapcsolatos belátás megszerzésére. Különösen igaz ez abban az esetben, ha nemcsak önerőből történik, hanem egy képzett és hiteles személy, tanító segítséget nyújt a befogadásban és értelmezésben.

Ha a kereszténység fogalomhasználatából indulunk ki, láthatjuk, hogy ott nagyon fontos szerepet kap az agapé57, vagyis az aktív szeretet, és az elemzésekben gyakran ezzel hasonlítják össze a buddhizmusban használt szanszkrit/páli karuṇā és szanszkrit maitrī = páli mettā fogalmat. A buddhista szövegek angol fordításaiban a maitrī esetében a loving kindness, a karuṇā esetében pedig a compassion (esetleg a sympathy) fordítást használják. A zen mester Thich Nhat Hanh tanításaiban is sűrűn

\footnotetext{
${ }^{57}$ A Szentírás görög fordítói a szeretetre az agapé szót alkalmazzák, amely az erósz ellentéte, mivel utóbbi jelentéstartalma túlságosan érzéki. A 'barátság' jelentésű philia viszont nem elég erős az önmagát ingyenesen odaadó szeretet kifejezésére. Az agapé az első keresztények testvéri étkezését is jelentette, amelynek során az eukarisztiát ünnepelték. A kifejezés főleg Szent János evangéliumában és leveleiben, valamint Pál apostol leveleiben fejezi ki Isten vagy Krisztus irántunk való szeretetét, amelyből az emberek közötti szeretet is származik. (Kránitz-Szopkó [2001], p. 12.) Dionüsziosz Areopagitesz (Aeropagita Dénes) azt írja erről, hogy a szeretet maga mindennek az oka, mindent magában foglal, teljességre vezet és megfordít mindent. Ő még az erósz kifejezést használja, és azt mondja, hogy ez az isteni erósz maga a (kisugárzó) jóság, amely önmagáért van. Ez a létezők jóságos szeretete, amely önmagában végtelenül létezik a jóban. Aquinói Szent Tamás kommentárjában úgy magyarázza, hogy itt Dionüsziosz arról beszél, milyen Isten szeretete, aki jóságának végtelenségében mindent szeret. Ez a szeretet pedig magukban a létezőkben is jóságot hoz létre. (Hivatkozza Chenu [1999], pp. 75-6)
} 
találkozhatunk a compassion, love, loving kindness kifejezésekkel, amelyeket magyarra az együttérzés, szeretet és szerető kedvesség terminusokkal fordítanak. Az alábbiakban ezeket a kifejezéseket nézzük meg közelebbről. ${ }^{58}$

A szanszkrit maitrī szó a mitra (barátság) szóból ered. A maitrī páli megfelelője a mettā, amely számos jelentést hordoz: szerető kedvesség, barátságosság, barátság, jóakarat, jóindulat, közösség, jó viszony, egyetértés, harmónia, ártalmatlanság, erőszakmentesség, közös hullámhossz, mások érdekeivel való törődés. A különféle meghatározások szerint a mettā a mások jóllétére, javára és boldogságára irányuló erős kívánságot, akaratot, jóindulatot, kedvességet jelenti (parahita-parasukhakamana). A mettā lényegében egy olyan altruista szeretetet és barátságosságot jelent, amely megkülönböztetendő a pusztán önérdeken alapuló kedvességtől. A mettā olyan attitűd, amely elutasítja az offenzív fellépést, és hiányzik belőle a keserűség, neheztelés vagy bármilyen típusú ellenségeskedés. Ehelyett olyan barátságos érzületet, elfogadást és jóindulatot fejleszt ki, amely mások jóllétének és boldogságának keresésére irányul. Az igazi mettā mentes az önérdektől. A közösség, szimpátia és szeretet szívből jövő érzésében jelenik meg, és a gyakorlás révén határtalanul képes növekedni, leküzdve minden társadalmi, vallási, faji, politikai és gazdasági akadályt. Így tehát a mettā tulajdonképpen az egyetemes, önzetlen és mindent átfogó szeretetet jelenti. A mettā szanszkrit megfelelője, a maitrī használatának jellemző példája a mahā-maitrī, vagyis a nagy jóindulat/kedvesség (angolul great kindness), valamint a sarvasattva-maitrī-vihāra, ami azt jelenti, hogy jóindulattal viseltetni minden lény iránt (living with kindness towards all beings). A mettā/maitrī angol fordítása a loving kindness. (Lásd elsősorban Watanabe [2005] és Buddharakkhita [1989])

A szanszkrit karuṇā főnév a kṛ̣ igéből ${ }^{59}$ származik, eredeti jelentése siránkozás/sajnálkozás vagy szomorú sírás. Az M. Monier-Williams-féle szanszkrit-

\footnotetext{
58 A fogalmak elemzéséhez több forrásból is tájékozódtam, és a fejezet ezen információk összedolgozásából született meg, így nem feltétlenül tüntethetők fel pontosan a hivatkozások az egyes helyeken. Összességében az alábbi forrásokat használtam fel: Thich Nhat Hanh $A$ béke légy te magad c. könyve; Watanabe Shogo Compassion (Karuñā) and Pity (Anukampā) in Mahāyāna Sūtras c. tanulmánya, amely az M. Monier-Williams-féle szanszkrit-angol szótárra is hivatkozik; Acharya Buddharakkhita Metta - The Philosophy and Practice of Universal Love c. munkája (a théraváda buddhizmus keretein belül); valamint a vonatkozó Wikipédia-szócikkek magyarul és angolul (Mettá/Mettā, Karuná/Karuṇā).

${ }^{59}$ Jelentése: megsérteni, megsérülni, megölni. A karuṇa melléknév pedig azt jelenti, hogy szomorú, gyászos, nyomorúságos, siralmas (mournful, miserable, lamenting).
} 
angol szótárban a részvét, együttérzés, könyörület (pity, compassion, mercy) fordítással szerepel. A fogalom a buddhizmusban a mások szenvedése iránti együttérzést és a szenvedésük megszüntetése iránti vágyat fejezi ki. Angolul rendszerint a compassion ${ }^{60}$ vagy sympathy ${ }^{61}$ szóval fordítják. A mahā-maitrī mellett megjelenik a mahā-karuṇā (nagy részvét) fogalma is - ezek kifejezetten a Buddhák és bódhiszattvák együttérzésére és részvétére utalnak. Ebben az esetben mivel a Buddha oly módon érez együtt az élőlényekkel, mintha a szenvedésük a sajátja lenne, úgy is hivatkoznak rá, mint a „lényegi azonosságon alapuló nagy részvétre”. A maitrī és a karuṇā mint a Buddhák és bódhiszattvák tulajdonsága a négy brahmavihāra (isteni állapotban való időzés, szó szerint: istenek lakhelye) egy-egy fokozata 62 .

A maitrī és a karuṇā tehát eredetileg két külön fogalom volt a barátságosság/kedvesség/jóindulat és a bánat/együttérzés/részvét kifejezésére. Az idők során a jelentésük azonban egyre inkább egymás kiegészítőjévé vált, és már együtt fejezték ki a szenvedés megszüntetése és a boldoggá tevés koncepcióját. Számos szútra és értekezés mondja ki expliciten, hogy a mahájána buddhizmus szellemiségében alapvetően az együttérzésre épül. A kínai madhjamaka irányzat egyik iratában, a Da zhidu lunban is szerepel az a sor, hogy a jóindulat/kedvesség a buddhista út alapja. A bódhiszattva ugyanis a lényeket úgy látja, hogy azokat különféle szenvedések gyötrik - a születés, az öregkor, a betegség és a halál szenvedése, különféle testi és szellemi szenvedések, a jelen élet és a következő élet

\footnotetext{
${ }^{60}$ Ha megnézzük e kifejezés etimológiáját, akkor láthatjuk, hogy a compassion latin eredetű, a com(együtt) és a passion szóból tevődik össze, amelynek eredeti jelentése fájdalom miatti szenvedés (suffering of pain). A Passion (Passió) nagybetűvel kifejezetten Krisztus szenvedéseire utal, és a mártíromságot is jelöli. Ez az egyházi latin 'passi' (szenvedni) szóból származtatható. Az angolban a passion rendszerint egy heves vagy ellenállhatatlan érzetre vagy érzésre utal, és a korai használatában a latin eredet miatt mártíromságot, szenvedést vagy nyomorúságot jelentett. A compassion szó szerint azt jelenti, hogy „együtt szenvedés”, és ezért ez a karuṇa legalkalmasabb fordítása.

${ }^{61}$ A sympathy szintén két részre bontható: a sym- és a pathy is görög eredetű. A sym- a syn- előtag hasonult alakja, és azt jelenti, hogy „együtt, egyformán” (together, alike), a pathy pedig a görög 'patheia', vagyis szenvedés szóból ered. Összetételi alakjában (magyaros átírásban szümpatheia) szó szerinti jelentése szintén az „együtt szenvedés”. Tehát mindkét említett kifejezés (compassion és sympathy) árnyalataiban az együttlétezés egyetemes fogalma jelenik meg.

${ }^{62}$ Négy fokozata: 1. határtalan szeretet (maitrī); 2. határtalan részvét (karunāa); 3. határtalan öröm (mudita); 4. határtalan közömbösség (upeksha). A négy mérhetetlennek is nevezik, a gyakorlásuk jó ellenszere bizonyos negatív állapotoknak, mint amilyen a mohóság, harag, rosszindulat, büszkeség, sóvárgás stb.
} 
szenvedése -, és ez felkelti benne a nagy jóindulatot és a részvétet, hogy megmentse őket ettől a szenvedéstől. Ez pedig kiváltja a felébredésre való törekvést, és keresni kezdi a felülmúlhatatlan tökéletes felébredést (anuttarā samyaksambodhi). A jóindulatot és a részvétet a Da zhidu lun a felébredés vagy megvilágosodás alapjának tartja. A 'jóindulat' fogalom arra utal, hogy a bódhiszattva az élőlényekre szeretettel gondol, és a békét és boldogságot az élőlények javára szólóan keresi. A 'részvét' kifejezés pedig arra, hogy az élőlényekre sajnálattal gondol, és megtapasztalja a testi és szellemi szenvedés különféle módjait a ciklikus létezés öt ösvényén. A karuṇā funkciója tehát az élőlények iránti részvét, valamint a fizikai és szellemi szenvedésükben való osztozás. (Lásd Watanabe [2005])

Thich Nhat Hanh maga azt írja, hogy a szanszkritban a szeretetre használják a maitrī és karunā szavakat, és a szeretet nem különbözik a megértéstől (prajñāa/pañ̃̃a).
„Amikor megértesz valamit, nem tehetsz mást, mint hogy szeretsz. Nem lehetsz dühös. A megértés kifejlesztéséhez azt kell gyakorolnod, hogy minden élőlényre együttérzéssel tekintesz. Amikor értesz, akkor szeretsz, amikor pedig szeretsz, akkor természetesen cselekszel úgy, hogy enyhíted az emberek szenvedését. Azt, aki felébredett, aki tud és ért, buddhának hívják. A buddha mindegyikünkben jelen van. Mi is lehetünk felébredettek, megértők és szeretetteljesek. Azt szoktam mondani a gyermekeknek, hogy amikor az édesanyjuk vagy az édesapjuk nagyon megértő és árad belőle a szeretet, sokat dolgozik és gondját viseli a családnak, mosolyog és kedves, mint egy virágszál, akkor azt mondhatják neki: »Anyu (vagy Apu), ma teljesen buddha vagy.«" (Nhat Hanh [2003] pp. 24-5.)

Az interjúk során az derült ki, hogy a megkérdezettek számára is hasonlót jelent a szeretet, az együttérzés, a kedvesség. Bár van, aki a 'szeretet' szót talán szívesebben használja, úgy gondolom, hogy a nyilvánvaló egyéni különbségek mellett az idézett megszólalásokban egyértelműen felfedezhető az a széles jelentéstartomány, amelyet az elemzésben bemutattam.

„Én szeretem a szeretet szót használni annak ellenére, hogy eléggé elcsépelten használjuk mi emberek. Az Erich Fromm-i értelemben tudom ezt venni, hogy ez egy cselekvő munka, amiben ott az ismeret, a törődés, a felelösség és a tisztelet, tehát nem érzelemként tekintek rá. ${ }^{63}$ Ebben benne van az, hogy ha szeretek

${ }^{63}$ Fromm és Suzuki például így írja le az ismeret (bölcsesség) és a szeretet összefüggését: Az ádarsanadnyána (vagyis a tükörtudás, amikor „áttörtünk a tudattalan sötétjén, s éppúgy látunk minden dolgot, ahogy az arcunkat látjuk egy csillogóan tiszta tükörben”), „amely felfedi magát, amikor a tudattalan, azaz az álaja-vidnyána mélye átszakad, nem más, mint a pradnyáintuíció. 
valakit, törődök szó szerint, tehát szenvedek. El tudom fogadni, hogy az együttérzést használja a buddhizmus, nagyon mélyen érint, ahogy Jan interpretálja, és nincs a másik oldal nélkül. A buddhizmus az együttérzésről mond dolgokat, a szeretetet pedig nagyon sokféleképpen engedtem át magamban - nem tekintem függetlennek a két dolgot, mindkettőben közös a figyelem, a figyelem odaszentelése. Meg a tudás, hogy arra tudsz helyesen reagálni, amit helyesen látsz. Nem mindegy, hogy ezeket a fogalmakat ki boncolgatja, mert nem mindegy, hogy mi van a szívében. Van-e közös felület, amin tud tartózkodni, és egy kicsit erre meg arra is nézni, vagy az egyik oldalon van, és az egyik oldalból próbálja megérteni a másik oldalt. Így nem lehet, ahhoz hogy megértsük, legalább egy picit bele kell helyezkedni." (Eszter)

„Olyan mestert szeretnék [Magyarországon], akitől tudnék tanulni, akiből sugárzik a compassion, a kedvesség." (Ádám)

„Nekem a szeretet az egy tudatállapot, nem egy érzés, hanem hogy abban vagyok, hogy egy vagyok mindennel, és össze vagyok kapcsolódva egy tudati szinten, egy tudatossággal mindennel. Benne van az ember egy hálóban, aminek a része. Az együttérzésben már benne van, hogy vagy te és vagyok én. Benne van, hogy ketten vagyunk. De többek között azért is vagyok tanár, mert teljesen rá tudok hangolódni a másik emberre." (Nikolett)

„Konceptuálisan nem tudok mit kezdeni vele [a buddhizmussal], hogy nincs megszületés és nincs meghalás, ezt én nem értem. De azt, hogy együtt vagyunk egyek, azt értem. És amikor az apám nem jó fej, vagy amikor én valamilyen vagyok, akkor felfedezem magamban az apámat, és nem úgy gondolok rá, mint egy elpusztítandó részemre, szóval ez az együttérzés. Én nagyon sok mindent hozok az apámtól, ami ítéletesség, rugalmatlanság, ilyen merev elvesség. Mindig azt tapasztaltam, hogy megosztottság van, hogy a szeretet az olyan, hogy fáj. És akármennyire is akarok kibújni a bőrömből, ez az, amit a zsigereimben hordok, és sokszor én is így tudok szeretni. És akkor, amikor ezt úgy bele lehet mártani az együttérzésbe, akkor abba lehet hagyni azt is, hogy magamat üldözzem emiatt folyamatosan. Szóval ha van együttérzés, akkor meg lehet érteni, hogy miért úgy van." (Mariann)

Az interjúkból ezen a ponton az derült ki, hogy a közösség tagjai számára a buddhista irodalom tanulmányozásánál fontosabb egyrészt a tanító interpretációja, másrészt a saját megélés. Úgy gondolom, hogy függetlenül attól,

\footnotetext{
Az elsődleges akarat, amelyből minden lény születik, nem vak és tudattalan; csak tudatlanságunk (avidjá) miatt látszik annak, mely homályossá teszi a tükröt, s így még létének tényét sem fogjuk fel. Mi vagyunk a vakok, nem az akarat, amely elsődlegesen és alapvetően elvont, de akarati is. Az akarat pradnyá és karuná, bölcsesség és szeretet. A relatív, korlátozott, véges síkon az akarat csak töredékesen mutatkozik meg; hajlamosak vagyunk úgy tekinteni, mint valamit, ami elválik agytevékenységünktől. De amikor az ádarsanadnyána tükrében fedi fel magát, akkor »Isten, amilyen önmagában «. Benne a pradnyá nem különül el a karunától. Amint az egyik neve fölmerül, óhatatlanul társul hozzá a másik." (Fromm-Suzuki [1989] pp. 84-7.) (A szövegben a pradnyá a helytelen 'pradzsná' átírásban szerepelt, ezért módosítottam.)
} 
honnan származik az ezzel kapcsolatos ismeret, illetve hogy a megkérdezett egyáltalán a buddhizmushoz köti-e azt, a szeretet és együttérzés általuk megadott jelentéseiben - akár áttételesen - felfedezhetők a buddhista hatások. A terepmunkás megfigyeléseimből pedig azt a következtetést tudtam levonni, hogy a Dharma-tanítások, a szertartások és a családi Dharma-megosztások mind azt a célt (is) szolgálják, hogy e fogalmak jelentései kisebb mértékben intellektuális síkon és nagyobb mértékben a gyakorlati-érzelmi dimenzióban fel legyenek tárva. A tanítónak ebben kiemelt szerep jut, az ő értelmezése és személyes példamutatása határozza meg leginkább az átadás sikerességét.

\subsubsection{A buddhista szövegek tanulmányozása}

Ebben a fejezetben a fentieknél tágabban arról lesz szó, hogy a megkérdezettek mennyire és milyen módon tanulmányozzák a buddhizmussal kapcsolatos irodalmat. A közösség tagjai egészen eltérő mértékben rendelkeznek a buddhizmusra vonatkozó elméleti tudással, egyáltalán, ezzel kapcsolatos érdeklődéssel. Vannak, akik a közösségbe kerülésük előtt egyáltalán nem találkoztak a buddhizmussal, és olyanok is, akik bizonyos szintű ismeret birtokában kifejezetten buddhista közösséget kerestek. Az elméleti érdeklődés ezzel korrelál, és úgy tűnik, hogy a közösségben való tagság csak kismértékben változtatott az elmélettel kapcsolatos eredeti hozzáálláson. Az interjúk során az derült ki, hogy ez az egyik olyan kérdés, amely bizonyos szinten konfliktust jelent a tagok számára. Az elvonulások programjában jellemzően megfelelőnek tartják az elmélet és a gyakorlat viszonyát, de a havi találkozók többeket éppen az elmélet hiánya miatt nem vonzanak. Jelenleg azonban egy olyan átalakulás zajlik a közösségben, amely kezelni igyekszik a különféle igényeket, és a szokásos menetrendben (gyakorlás, éneklés, beszélgetés, teázás) a buddhizmussal kapcsolatos előadások is helyet kaphatnak.

A buddhista tanok megértésének kérdését ketté lehet itt bontani. Az interjúalanyoknál rákérdeztem egyrészt arra, olvasnak-e buddhista szövegeket magyarul, angolul vagy más nyelven, másrészt arra is, hogy mennyire értik meg az elvonulásokon a tanításokat angolul, illetve mit gondolnak a magyar tolmácsolásról. Erről mindenkit megkérdeztem, függetlenül attól, hogy ért-e annyira angolul, hogy 
össze tudja vetni a fordítást a tanító beszédével, mivel egy ilyen hosszú programon - különösen, ha az illető többször is részt vett már elvonuláson - mindenképpen kialakul valamilyen benyomás a tolmácsolásról. Ahogy az egyik, angolul nem beszélő résztvevő fogalmazott: „A jó tolmácsról érezhető, tudható, hogy jól fordít, mert egyben van, amit fordít. Mindig is észrevettem a rossz tolmácsolást."

Visszatérve a buddhista irodalom olvasásának kérdésére, az interjúk azt mutatták, hogy ebben a meghatározó az, milyen módon találkozott az adott személy a buddhizmussal. Az elvonulás egyik résztvevője először indiai utazása során került érintőlegesen kapcsolatba a buddhizmussal, ami aztán az Egyesült Államokban, egy egyetemi kurzuson - valamint különféle meditációs csoportokban és buddhista közösségekben - vált intenzívebbé, és ma is csak angolul olvas a témában. Egy másik megkérdezett az angliai munkája idején kezdett vele foglalkozni, ekkor interneten rendszeresen hallgatott buddhista tanításokat (részben az angolnyelv-tudása fejlesztése érdekében), és jelenleg is leginkább audiofelvételeket hallgat - naponta átlagosan háromnegyed-egy órát, ahogy fogalmazott: „ez egy olyan fontos szál volt az életemben, hogy megragadtam mellette". Csak angol nyelvű tanításokat hallgat, mivel nem talált hasonló színvonalú magyar nyelvű tanítót.

Egy harmadik résztvevő meglehetősen sokat foglalkozik a buddhizmus elméleti oldalával nemcsak magánemberként, hanem a szakmája berkein belül is. A megkérdezettek közül számára volt a legfontosabb az olvasott szöveg minősége. Ő kiemelte a buddhista főiskola szerepét a szövegek magyarra való átültetésében, és bár azt gondolja, hogy a keleti nyelvről nyugatira való átültetés során mindenképpen elvesznek bizonyos jelentések, ez elkerülhetetlen, mert „más logika és világ, más agyhuzalozás szerint vannak felépítve, de amennyire lehet, azért jók a magyar fordítások". Említett néhány konkrét fogalmat is, például hogy a mindfulness szó már angolra is nagyon rossz fordítás, mert a páliban inkább 'éberség'-et jelent, és a különféle magyar megoldások - 'éber figyelem', 'tudatos figyelem', 'tudatos jelenlét', 'éber jelenlét' - sem igazán jók. Nehezíti a dolgot, ha a keleti nyelvről angolra fordított szöveget kell magyarra átültetni, „mert ott van még az everness, ami szintén 'jelenlét'-et jelent, meg a consciousness, ami 'tudatosság', és akkor fordítsd le magyarra, hogy mindful conscious everness nagyon nehéz így, nem lehet a páli terminológiát visszaadni egyetlen nyugati nyelven sem, de a főiskolán kialakult ennek egy iskolája”. 
A többi megkérdezett közül többen említettek egy-egy számukra fontos magyar nyelvű olvasmányt (pl. a Buddha beszédei gyűjteményt vagy Bhikkhu Bodhi A Nemes Nyolcrétü Ösvény című könyvét), valamint Thich Nhat Hanh magyarul megjelent könyveit is sokan olvasták, de vannak, akik az utóbbin kívül egyáltalán nem olvastak buddhista irodalmat. Ennek jellemző okaként egyrészt nem az érdeklődés, hanem - főleg azoknál, akiknek gyerekük/gyerekeik vannak - az idő hiánya merült fel. Másrészt azt is többen megfogalmazták, hogy inkább tizenéves korukban olvastak sokféle - többek között buddhista - irodalmat. Emellett több olyan emberrel is beszéltem, akik szintén tizen- vagy huszonévesen olyan tanáraiktól hallottak a buddhizmusról, akiket meghatározó, hiteles embereknek tartottak. Összességében az a kép rajzolódott ki, hogy a megkérdezetteknél a buddhizmus iránti érdeklődés vagy a nagyon „befogadó” tizenéves korban alakult ki olvasmányok alapján, vagy pedig egy-egy fontos személy, tanár vagy buddhista tanító indította vagy mélyítette el. (A tanítóval - a közösség tanítójával, illetve általában véve a tanító szerepével - egy későbbi fejezet foglalkozik.) 


\section{A kommunikáció színterei}

\subsection{Az elvonulás}

Minden vallásban/tanban megvannak az elkötelezettséget, a meggyőződést és a közösséghez tartozás kifejezo, támogató-megerősítő rítusok, szertartások, gyakorlatok. Utóbbiak a buddhizmusban különösen fontosak és sokrétúek, tulajdonképpen az élet minden egyes tevékenysége végezhető buddhista gyakorlásként. A buddhizmus követői magukat sokszor nem is buddhistának, hanem gyakorlónak (angolul practitioner) tartják - ezt Jan Boswijk is hangsúlyozta -, amivel azt fejezik ki, hogy a mindennapi gyakorlással változtathatók meg, terelhetők más mederbe az úgynevezett szokásenergiák. Ezt támasztja alá Kárpáty Ágnes kutatása is: „(...) az általam megkérdezettek közül csupán néhányan nevezték magukat buddhistának. Ennek több oka van, amelyek közül most csak azt említeném meg, hogy jó néhány megkérdezett szerint a »buddhista« és a »buddhizmus« kifejezés európai műszó. A »buddhisták« Tibetben és Indiában »Buddha követőjének«, »törekvőnek« vagy »gyakorlónak« mondják magukat, hitüket pedig a páli Dhamma szóval (»Tanítás«, »Törvény«) jelölik és e kifejezéseket részesítették előnyben beszélgetőpartnereim is." (Kárpáty [2001], p. 76.) Ezért bár nagy hasznuk van az olyan intenzív tevékenységeknek is, mint amilyen egy elvonulás, igazi változást a napi gyakorlással lehet elérni. Ekképpen a rendszeres napi 10-20 perces meditáció és a tevékenységek tudatos (éber figyelemmel/jelenléttel való) végzése többet ér, mint az évi egy-két elvonulás. ${ }^{64}$

Ugyanakkor ezek az egy- vagy akár többhetes elvonulások egyre népszerúbbek a nyugati világban, egyrészt mivel kiválóan alkalmasak a rekreációra, stresszoldásra, megnyugvásra, másrészt energiát, lökést adnak az év közbeni gyakorláshoz. Az elvonuláson a résztvevő igyekszik a mindennapi szokásait, „kifelé irányultságát" maga mögött hagyni, kilépni a komfortzónájából, lebontani a falait, lecsendesedni és bizonyos értelemben „lemeztelenedni”. Az egyes elvonulások szigorúsága eltérő, de bizonyos alapok, a cél és az eszközök közösek mindegyikben.

\footnotetext{
64 „Valamiben benne lenni, vagy néha odamenni és megmártózni benne, az óriási különbség. De az se rossz, mert mindenki elindul az úton valahogy, nem akarom minősíteni, hogy melyik a jobb vagy rosszabb." (László)
} 
A következőkben bemutatom a Thich ${ }^{65}$ Nhat Hanh szerzetesi közössége ${ }^{66}$, a franciaországi Plum Village által szervezett elvonulások célját és általános programját.

\subsubsection{Az elvonulás Thich Nhat Hanh franciaországi közösségében}

Az elvonulás (retreat) lehetőséget kínál az egyszerű és békés élet élvezetére, az éber figyelem (mindfulness) gyakorlására annak érdekében, hogy mindennapi

${ }^{65}$ A Thich jelentése 'mester'.

${ }^{66}$ Thich Nhat Hanh (vagy ahogyan tanítványai nevezik: Thay) korunk egyik legismertebb és legnagyobb tekintélynek örvendő zen buddhista mestere, költő, béke- és emberi jogi aktivista. Különleges életút áll mögötte. Vietnam középső részén született 1926-ban, majd tizenhat éves korában szerzetes lett. A vietnami háború azzal a kérdéssel szembesítette a szerzeteseket, hogy ragaszkodjanak-e a szemlélődő élethez, és továbbra is meditáljanak a kolostorokban, vagy pedig segítsék a falvak bombázásoktól és más háborús pusztításoktól szenvedő lakóit. Nhat Hanh azok közé tartozott, akik úgy döntöttek, hogy mindkettőt művelik, és segédkezett az „elkötelezett buddhizmus” mozgalom megalapításában. Életét azóta annak szenteli, hogy az egyén és a társadalom javára szolgáló belső átalakuláson munkálkodjon.

Az 1960-as években Saigonban (ma Ho Si Minh-város) megalapította a Tiep Hien Rendet (Order of Interbeing), továbbá a Fiatal Szociális Munkások Iskoláját (School of Youth Social Service), egy alulról építkező segélyszervezetet, amely lebombázott falvakat épített újjá, iskolákat és orvosi központokat hozott létre, hajléktalanná vált családoknak teremtett új otthonokat, és mezőgazdasági szövetkezeteket szervezett. A mintegy tízezer önkéntes diákot a soraiban tudó szervezet az erőszakmentesség és az együtt érző cselekvés buddhista elvei alapján működött. Nhat Hanh buddhista egyetemet, könyvkiadót és tekintélyes békeaktivista folyóiratot is alapított, dacolva azzal, hogy a hatóságok ezt nem nézik jó szemmel.

Miután 1966-ban békemissziós körutat tett az Egyesült Államokban és Európában, megtiltották, hogy visszatérjen Vietnamba. Az ezt követő amerikai utazásai során a szövetségi hivatalnokokkal és a Pentagon tisztviselőivel, köztük Robert McNamarával folytatott megbeszélésein állt ki a békéért. Könnyen lehet, hogy megváltoztatta az amerikai történelem menetét, amikor meggyőzte Martin Luther Kinget arról, hogy nyilvánosan helyezkedjen szembe a vietnami háborúval, nagyban segítvén ezzel a békemozgalom aktívabbá válását. A következő évben King Nobel-békedíjra jelölte. Ezt követően Nhat Hanh vezette a buddhista delegációt a párizsi béketárgyalásokon.

1982-ben franciaországi száműzetésében alapította meg a Plum Village buddhista közösséget, ahol folytatja tevékenységét a Vietnamban és szerte a harmadik világban élő szenvedőkért: a (sokszor a tengeren át csónakokon érkező) menekültekért, a politikai foglyokért és az éhező családokért. A Vietnamot megjárt amerikai katonákkal végzett munkája, meditációs elvonulásai és a meditációról, az éber figyelemről és a békéről szóló nagyszámú írása szintén elismerést hoztak számára. 2001 szeptemberében, mindössze néhány nappal a Világkereskedelmi Központ ellen elkövetett öngyilkos merényletek után, az erőszakmentesség és a megbocsátás volt a központi témája a New York-i Riverside templomban tartott emlékezetes beszédének. 2003 szeptemberében az amerikai Kongresszus tagjait szólította meg, amikor kétnapos elvonulást tartott számukra.

Thich Nhat Hanh továbbra is Plum Village-ben él, az általa alapított meditációs közösségben, ahol tanít, ír és kertészkedik, emellett elvonulásokat vezet világszerte „az éber figyelemmel élt élet művészetéről”. Forrás: http://www.szelidmosoly.hu/index.php/tanitoink/thich-nhat-hanh (Utolsó letöltés: 2016. február 20.) 
életünkben nagyobb szabadságot, több békét és boldogságot tapasztalhassunk meg. Az elvonuláson időt szánhatunk arra, hogy „befelé” figyeljünk, ami segíthet az egyéni nehézségeink és a társadalmi problémák kezelésében, „átalakításában”. Megtanulhatjuk azt, hogyan tudjuk a napi tevékenységeinket éber figyelemmel végezni és az életünk minden pillanatát mélyebben megélni. Az elvonuláson a nap minden egyes tevékenysége ennek jegyében zajlik: a séta, az étkezés, a munka, az ülés vagy akár egy csésze tea elfogyasztása is meditációnak minősül. Különös hangsúlyt kapnak a csoportosan végzett tevékenységek, a közösségben rejlő erő és támogatás. ${ }^{67}$

A napi program az évszaktól és az elvonulás jellegétől, valamint némileg az elhelyezésül szolgáló „falucskától”68 függően változik. Mindennap sor kerül ülő és sétáló meditációra, valamint az étkezés és a munka közösen, éber figyelemmel történik. Az esti utolsó tevékenység végétől a másnapi reggeli végéig pedig a „nemes csend" időszaka következik. A hét egy napja úgynevezett lustálkodás-nap (Lazy Day), amikor semmilyen hivatalos programra nem kerül sor. A speciális elvonulásokon, így a nyári nyitó 21 napos elvonuláson jellemzően heti négy Dharma-tanításra (Dharma Talk) kerül sor, ilyenkor az egész közösség összegyűlik. A tanítást rendszerint Nhat Hanh mester (Thay) tartja, amit sétáló meditáció követ. A tavaszi, őszi és téli elvonulásokon minden csütörtökön és vasárnap egy-egy teljes, éber figyelemmel teli napra gyűlik össze a közösség valamelyik falucskában, a világi gyakorlók számára pedig egy további ilyen nap, a kedd is rendelkezésre áll. A hét többi napját mindenki a saját spirituális családjával tölti. A világi gyakorlók a szükséges eligazítást a gyakorlásról és a napirendről az elvonulásra való megérkezéskor kapják meg. ${ }^{69}$

\footnotetext{
${ }^{67}$ http://plumvillage.org/retreats/visiting-us/ (Utolsó letöltés: 2016. február 20.)

${ }^{68}$ Plum Village jelenleg három kolostorból, úgynevezett hamletekből, falucskákból áll. Ezek önálló közösségeket képeznek, ahol a szerzetesek élnek és a világi gyakorlók tartózkodnak az elvonulások alatt: spirituális családokat alkotva itt étkeznek, gyakorolnak és pihennek.

${ }^{69}$ Egy tipikus napi program az alábbiak szerint néz ki:

5:00 - Ébresztő harangszó; 6:00 - Ülő meditáció, amit szútraolvasás, lassú séta vagy földérintés követ; 7:30 - Reggeli; 9:00 - Dharma-tanítás/osztályfoglalkozás/prezentáció/örömteli munka (working meditation); 11:30 - Sétáló meditáció a szabadban; 12:30 - Ebéd; 13:30 - Pihenés vagy választható vezetett relaxáció; 15:00 - Örömteli munka; 18:00 - Vacsora; 20:00 - Dharma-megosztás (Dharma Discussion), személyes tanulófoglalkozás, ülő meditáció vagy más közösségi gyakorlás; 21:30 - A nemes csend kezdete; 22:00 - Villanyoltás. Kora reggel vagy délután lehetőség van az egyéni testgyakorlásra (jóga, tajcsi, csikung, kocogás) vagy az időjárástól függően csoportos
} 
Bizonyos változtatásokkal a Plum Village-beli elvonulások mintáját követik a Szelíd Mosoly elvonulásai is, amelyeket az alábbiakban ismertetek.

\subsubsection{A terepmunka - résztvevő megfigyelés}

Összesen négy elvonuláson vettem részt: 2014 augusztusában és 2015 júliusában egy-egy (utazással együtt) 6 napos (5 éjszakás) pannonhalmi bentlakásos, 2015 márciusában és 2016 februárjában pedig egy-egy 2 napos budapesti otthonalvós elvonuláson. ${ }^{70}$ A nyári elvonulásokat Jan Boswijk ${ }^{71}$, az első tavaszit Hilly Bol ${ }^{72}$, a másodikat Cuong Lu ${ }^{73}$ vezette - mindhárman Hollandiában élő Dharma-tanítók.

A 2014-es pannonhalmi elvonulás volt az első alkalom, hogy részt vettem a Szelíd Mosoly Buddhista Szangha bármilyen összejövetelén. Az elvonulásra való jelentkezés után rögtön alkalmam volt kommunikálni más résztvevőkkel, amikor a Pannonhalmára való utazás szerveződött „telekocsi” rendszerben. Már az utazás során tájékoztattam útitársaimat, hogy a személyes érdeklődés mellett kutatói szándékkal veszek részt az elvonuláson, majd a helyszínen is a lehető leghamarabb igyekeztem ezt közölni az ott lévőkkel. Akikkel sikerült beszélgetnem, gyakorlatilag mindannyian nyitottan és érdeklődéssel fogadták ezt, nem igazán tapasztaltam averziót, félelmet vagy bezárkózást. Az első pillanattól segítettek cipekedni, sátrat verni. A befogadói attitűd felülmúlta a várakozásaimat.

sportolásra (foci, röplabda, frizbi stb.) is. http://plumvillage.org/retreats/visiting-us/sampleschedule/ (Utolsó letöltés: 2016. február 20.)

${ }^{70}$ A helyszínek: Pannonhalma - Szent Jakab Ház, Budapest - Tűzmadár Ház, Budapest - A Tan Kapuja Buddhista Főiskola.

71 Jan Boswijk, Dharma-nevén a Béke Igaz Közvetítője 1944-ben született, pszichológus, pszichoterapeuta, a Hollandiában müködő Boswijk Intézet alapítója (www.centrumboswijk.nl). 1998 óta tagja a Kölcsönös Létezés Buddhista Rendjének (Buddhist Order of Interbeing), Thich Nhat Hanh zen mester 2004-ben avatta Dharma-tanítóvá. Elsősorban Hollandiában, Belgiumban és Németországban tartott programokon és elvonulásokon tanít és osztja meg a Dharma-tanításokat. Különleges kapcsolatot ápol Magyarországgal, ahol évente kétszer buddhista elvonulást vezet. (http://www.szelidmosoly.hu/index.php/tanitoink/jan-boswijk) (Utolsó letöltés: 2016. február 20.)

${ }^{72}$ Hilly Bol eredeti foglalkozása szerint orvos, jelenleg civilben hospice-szolgálatban dolgozik: hárfán játszik a haldokló betegeknek.

${ }^{73}$ Cuong Lu 47 éves, Vietnamban született. Thich Nhat Hanh zen mester tanítványa, 16 éven át gyakorolt szerzetesként Plum Village-ben. Jelenleg Hollandiában él feleségével és gyermekeivel, börtönlelkészként dolgozik, és Dharma-tanítóként is népszerűvé vált. A Dharmát csodálatos útként ajánlja a mindennapok békésebbé tételére. Első alkalommal tartott programot Magyarországon. 
Az első délután az utazás, az érkezéskori teendők (a részvételi díj befizetése, a teázásokhoz magunkkal hozott tea és aprósütemény, egyebek átadása) és a berendezkedés jegyében zajlott: a régebbi tagok várták a többieket, berendezték a zendót ${ }^{74}$, előkészültek a vacsorához, valamint az érkezéskor kaptunk egy egészen rövid, néhány pontból álló házirendet ${ }^{75}$. Az első program a közös vacsora volt, amely a későbbi étkezésekkel ellentétben nem csendben zajlott, hanem ekkor hangzottak el a technikai és egyéb tudnivalók. A vacsorát a meditációval egybekötött megnyitó követte, amely kb. fél 10-ig tartott. Ezt követően megkezdődött a másnapi reggeli végéig tartó nemes csend 76 .

\begin{abstract}
${ }^{74}$ A zendó (zen-dō) a zen buddhizmus spirituális dódzsója (dōjō). A japán 'dódzsó' kifejezés szó szerinti jelentése „az út követésére szolgáló hely”, „a megvilágosodás útja/helye” (http://hu.wikipedia.org/wiki/Dódzsó), amely a harcművészetek gyakorlására szolgál („edzőterem”). Ekképpen a zendó a zen buddhizmusban a meditáció, a szellemi gyakorlás helye. Minden zen templom tartalmaz legalább egy zendót, amelyet a gyakorlás mellett ceremoniális célokra is használnak (http://en.wikipedia.org/wiki/Zendo). Az elvonuláson a zendó adott helyett a meditációknak, szertartásoknak, Dharma-tanításoknak, valamint a családi Dharma-megosztáskor valamelyik családnak.

${ }^{75}$ A házirend csak néhány, könnyen megtanulható és betartható dolgot tartalmazott: hogy az esti meditáció végétől a reggeli végéig él a nemes csend; hogy harangszó jelzi az ébresztést és a programok kezdetét, és ha halljuk, álljunk meg egy percre, és figyeljünk a légzésünkre, bármit is csinálunk éppen; hogy az étkezések csendben zajlanak; valamint hogy a zendóban ne fordítsuk talpunkat az oltár felé.
\end{abstract}

${ }^{76}$ A 2014-es nyári elvonulás napi programja az alábbiak szerint épült fel:

6:00 Ébresztő harangszóval

6:30 Meditáció, amely csendes ülésből, (vezetett) meditációból, lassú sétából és ismét csendes ülésből állt

8:00 Reggeli (a nemes csend a reggeli 15. percéig tartott)

9:00 Örömteli munka (parlagfűirtás, házak takarítása, zendórendezés, teafőzés, fényképrendezés a honlapra, étkezőtakarítás, mosdók takarítása, asztalok terítése, Dharma-tanítások összegyüjtése)

10:00 Dharma-tanítás

11:30 Sétáló meditáció

13:00 Ebéd

14:00 Pihenés (szabadprogram)

15:30 Az egyes napokon eltérő program: teljes relaxáció, meditáció, 5 éberfigyelem-gyakorlat, A föld három érintése gyakorlat

16:30 Dharma-megosztás családokban a délelőtti tanításhoz kapcsolódóan (lásd alább)

18:15 Vacsora szintén családokban (közös étkezőben, de a családok ültek egy asztalhoz)

20:00 Meditáció, illetve egyik este Ősök-szertartás (lásd később)

21.30 Éjszakai pihenés nemes csendben.

A nemes csend nem a teljes némaságot jelentette - alapvetően a befelé fordulást, az elmélyülést szolgáló csendről volt szó, olyan viselkedésről, amelynek során tiszteletben tartjuk mások „elvonulását”, tehát ha valakinek mondandója volt, azt halkan, suttogva kellett közölnie.

Az elvonuláson 46-an vettek részt, és az első napon mindenki be lett osztva egy úgynevezett családba, amely családfőt (a szangha egy régebbi tagját) is kapott. Az elvonulás teljes időtartama alatt ezek a 
A korábbi évek elvonulásaitól eltérően a 4. napon be lett iktatva egy ún. „lustálkodás-nap”, valójában egy délelőtt, amikor csak 7:15-kor kezdődött a (szabadon választott) meditáció, 8:00-tól a reggeli, azt követően pedig az ebédig szabadprogram volt - ennek során a résztvevők többsége együttesen ellátogatott az apátságra. Ezenkívül a vasárnap mint záró nap eltért a többi naptól, ezen a reggeli meditáció helyett az 5 éberfigyelem-gyakorlat ${ }^{77}$ átadásának szertartására (a menedékvételre) került sor, a délelőtti Dharma-tanítás kérdések és válaszok formájában lett megtartva, 14:15-kor pedig a záró esemény kezdődött (hivatalosan a tea-szertartás, de ebben az évben helyette egy kevésbé formális búcsúesemény, amikor a résztvevőknek lehetőségük volt elmondaniuk érzéseiket, tanulságaikat).

A 2015-ös elvonulás programja némileg változott, mivel az előző évben a közösség tagjai kicsit feszesnek érezték a programot. Ebben az évben kikerült a napból az örömteli munka mint külön programpont ${ }^{78}$, és az előző évtől eltérően nem jelentkezni lehetett bizonyos munkákra, hanem a családok kijelölt feladatot kaptak, amelyet az egész elvonulás során végeztek. Ezek az alábbiak voltak: zendórendezés, ebédlő (takarítás és terítés), mosogatás, teafőzés. Az időbeosztás így annyiban változott, hogy a Dharma-tanítás 9:30-kor kezdődött (ezenkívül az esti meditáció/szertartás kezdete 20:00 óra helyett 20:15 volt). Vasárnap pedig sor került a tea-szertartásra.

Ha a participációs elmélet mentén szeretnénk megvizsgálni ezeket a programokat, Horányi alábbi meghatározásából kell kiindulnunk: a „participáció

családok egy asztalnál vacsoráztak, valamint egymással beszélték át a Dharma-tanításon hallottakat. Részletesebben lásd alább.

A föld három érintése gyakorlat Thich Nhat Hanh zen mestertől származik - lásd a függeléket.

${ }^{77} \mathrm{Az}$ öt éberfigyelem-gyakorlat a buddhizmus öt fogadalmán alapul, amelyek az öléstől, a lopástól, a helytelen szexuális viselkedéstől, a hazugságtól és a bódító szerek használatától való tartózkodást foglalják magukban. Thich Nhat Hanh ezeket bontotta ki és alkalmazta a modern világ körülményeihez. A teljes szöveget lásd a függelékben.

${ }^{78}$ A kikerülés okát jól megvilágítja az alábbi interjúrészlet:

„Máriahalom egy szerves hely volt, Pannonhalma egy hibrid hely. Túlságosan letisztult, nincs benne semmi rossz. Valahogy benne vagy a természetben, de minden olyan szabályos, locsolgatnak, túlságosan tiszta. Máriahalom pont az ellentéte volt, a Gézának a cuccai mindenhol ott voltak, én ettől sokkal jobban szerettem, merthogy sokkal egészebben volt benne a világ. Ja, hát mi itt elvonulunk, de tudjad, hogy az ember cucca azért ott van két sarokkal odébb. Nekem pl. egy elvonuláson - lehet hogy megint azért, mert földközeli vagyok - [fontos], és nagyon sok embernek szüksége van arra, hogy tényleg legyen örömteli munka, és nyúljon már oda egy dudváért, és húzza ki. Itt nem lehetett csinálni, mert minden kész volt, egy steril környezet volt. Az élethez az is hozzátartozik, hogy én kutyapiszkot szedek hetente egyszer az udvaron." (Judit) 
kifejezés eredetileg - és a társadalomszervezésben manapság is - olyan folyamatot jelöl, amelyben egyének vagy csoportok összegyűlnek, hogy kommunikáljanak, interakcióba lépjenek egymással, információt cseréljenek vagy ismereteket halmozzanak fel bizonyos témákkal, problémákkal, döntésekkel kapcsolatban, s hogy a döntéshozatalban, a problémamegoldásban közösen vegyenek részt." (Horányi [2006], p. 14.) Az elvonulást ebben a keretben értelmezve úgy találjuk, hogy a következő különféle kommunikációs-participációs lehetőségek és alkalmak jelentkeznek az elvonulás előtt, alatt és után:

A szervezés folyamata: a szervezést a „mag”79 végzi, ugyanakkor már a szervezés során is részvételre hívják a leendő résztvevőket: szervezzék meg az utazást „telekocsi” rendszerben, hozzanak magukkal teát és süteményt, nassolnivalót a közös teázásokhoz, valamint kendőket, szobrokat, egyéb tárgyakat a zendó otthonosabbá tételéhez. Ezeken az állandó kéréseken kívül az adott elvonuláshoz sajátos kérések is kapcsolódhatnak, és mindezek jellemzője, hogy a résztvevők közösségi életét segítik (például lavór kérése a közös mosogatáshoz).

Utazás és megérkezés: a telekocsi rendszerű utazás a költségcsökkentésen kívül azzal a nyilvánvaló előnnyel is bír, hogy a résztvevők ráhangolódhatnak az elvonulásra, valamint adott esetben az először találkozó résztvevők megismerkedhetnek egymással, a rutinosabbak megkezdhetik az újak bevezetését a közösségbe. A megérkezésnél a mag tagjai fogadják a résztvevőket, akik átadják a magukkal hozott teát, egyebeket. A szervezők tájékoztatnak az elhelyezésről, és az újaknak átadják a házirendet. A rutinosabb résztvevők információkkal és szükség esetén fizikailag is segítenek az újaknak, ami oldja az újdonsággal és a megfelelési vággyal járó szorongást.

Elhelyezés: a szervezők által meghatározott szobabeosztás hozzájárul az egymást nem ismerők kapcsolatteremtéséhez. Ezt egyébként számos különféle intézkedés segíti még az elvonulás során (lásd alább).

Szertartásos étkezések: bár az ételért való sorban állás és az étkezések is csendben zajlanak (legalábbis az első 15 percük), ez nem csorbítja az együttlét érzését. A buddhista közösségekben a csendnek különleges szerepe van, segíti a befelé, illetve

\footnotetext{
${ }^{79}$ Ezt a szakirodalomban bevett kifejezést használták a szangha tagjai is az interjúk során.
} 
az adott tevékenységre figyelést, de ez a csend nem az egymástól való elkülönülést szolgálja. A csendes időszakok alatt a nonverbális kommunikációs formák előtérbe kerülnek, a tekintet, a mosoly és az érintés válik a közlés eszközévé.

Dharma-tanítások: a tanító ismereteket ad át a hallgatóságnak a buddhista tannal kapcsolatban. A Dharma-tanítás egy olyan előadás, amely ugyan elméleti jellegű, de célja a gyakorlás, a személyes fejlődés, a belátások megszerzésének segítése (9. kép). A tanítás stílusa és szellemisége a tanító személyiségének megfelelő. Jan Boswijk a tanításaihoz nemcsak a buddhista tant, de pszichológusi tudását is felhasználja, sokszor a praxisából vett gyakorlati példákkal együtt. Hilly Bol elvonulásán markánsabb szerepet kapott a halál témaköre, Cuong Luén pedig a boldogság és a nem-tudat meditáció kapcsolódása.

Dharma-megosztások: a Dharma-tanításokra épülő kiscsoportos foglalkozások. Alapvetően nem arra szolgálnak, hogy valamiféle vitát indítsanak el a tanításon hallottakról, inkább az érzelmek, belátások kifejezését ösztönzik. Fontos elemük a figyelmes hallgatás: a beszéd kezdetét és végét enyhe meghajlás (lótuszba tett kezekkel) jelzi, a többiek nem vágnak a beszélő szavába. A megszólalás nem kötelező, azonban a többiek számára akár sértő is lehet, ha valaki egyáltalán nem vonódik be a beszélgetésbe. A beszélgetés nem lineáris, egymásra reflektáló, az egyes megszólalások nem kell hogy kapcsolódjanak egymáshoz - a kommunikáció itt nem az információátadásra vagy vitára, nem az analitikus gondolkodásra, hanem az érzelmek megosztására, egymás megismerésére, az együttérzés és a belátás kifejlesztésére irányul. A résztvevők számára ez nehézséget okozhat, különösen azoknak, akiknek a mindennapi életében az analitikus gondolkodás, a tudományos elemzés, a másokra (mások munkáira) való hivatkozás, a gondolatok, közlések megindokolása és alátámasztása, a vita, érvelés a megszokott. Ugyanígy a zárkózottabb emberek számára a megnyílás, a zajos, „pörgős” környezetben élőknek pedig az egyes megszólalások közötti csend jelenthet nehézséget. Időre lehet szükség ahhoz, hogy ez a csend ne legyen kényelmetlen, és a résztvevő felismerje azt, hogy az éppúgy a kommunikáció része, mint a beszéd: teret biztosít a gondolatok tisztázására, lecsendesítésére, megalapozza a figyelmes hallgatást, a nyitottságot és a másik megértését. 
Meditációk: többféle meditációra is sor kerül - csendes, vezetett, valamint sétáló meditációra. Bár a meditációt a gyakorló alapvetően a befelé figyelés, az elme lecsendesítése, a jelen megélése érdekében végzi, a közösség fontos szerepet játszik benne: a közös gyakorlás sokak számára könnyebb, mint az egyéni, bár van, aki inkább a közösségépítő elemét hangsúlyozza. A kültéri sétáló meditáció lehetőséget teremt a természetben való szemlélődésre, a más élőlényekkel (növényekkel, állatokkal) való kapcsolatfelvételre (10. kép).

Szertartások: a szertartásoknak többféle szerepük is van. Egyrészt általánosságban a közösség és a közösséghez tartozás megerősítését szolgálják, másrészt a transzcendenssel való kapcsolat felvételét célozzák, harmadrészt az egyes szertartásoknak az adott szertartástól függően egyedi funkciójuk is lehet. A szertartásokon közös felkészültségek keletkeznek, amelyek a későbbiekben segítik mind az egyéni, mind a közösségi problémamegoldást. A transzcendenssel való kapcsolatfelvétel megerősíti a közösséghez tartozást és azon identitást, amely szerint az egyén a közösség tagjaként határozza meg magát; megteremti az elköteleződés alapját (de nem szükségszerűen vezet elköteleződéshez).

Közös munka: az „örömteli munka” kisebb csoportokra osztva történik. A célja kettős: egyrészt a szükséges munka (takarítás, zendórendezés, terítés, mosogatás stb.) elvégzése, másrészt a közösségi attitűd erősítése, a participáció megteremtése. Azzal, hogy mindenkinek részt kell vennie a munkában, a közös élettér megteremtésében és tisztán tartásában, mindenki bevonódik a közösségbe - és csökken az egyenlőtlen feladatvállalásból származó konfliktusok esélye.

Éneklések: különböző alkalmakkor kerül sor éneklésekre. Van, amikor a tanító kezdeményezi, pl. az egyébként csendes sétáló meditáció előtt - ilyenkor az éneklés körben állva történik, hangsúlyozva az egyenrangúságot, és lehetővé téve a nonverbális kommunikációt a csoportban. Az éneklés meditációs szerepet is betölthet.

Szabadprogramok: viszonylag kevés nem szervezett idő van az elvonuláson, de az egyes programok közötti időt, valamint a délutáni pihenőt ki lehet használni szabadprogramra: beszélgetésre, jógára, sétára, a tanítónak való ajándékkészítésre vagy egyszerűen csak egyéni/közös pihenésre. 
Hazautazás: amennyiben többen utaznak együtt, az élmények megosztása révén az elvonulás egyfajta lezárásaként is tekinthető.

A „minielvonulásokon” egy rövidebb programra kerül sor: meditációra (esetleg relaxációra), Dharma-tanításra, Dharma-megosztásra és szertartásos étkezésre.

A terepmunkát követően felvett mélyinterjúkban a felsorolt pontokkal kapcsolatban a résztvevőknek sok értékes meglátásuk volt. Az élményeiket, véleményüket, észrevételeiket, az ezekből levont következtetéseket a következő fejezetek fogják tartalmazni. Elsőként azonban az elvonulás központi terét kell megvizsgálnunk, ahol az étkezéseken, a pihenőidőkön és a kültéri sétáló meditációkon kívül az összes program zajlik. Mivel ez a hely egyúttal szakrális tér is, ebben a fejezetben lesz szó a rítusokról, szertartásokról.

\subsection{A szent (szakrális) tér, a szimbolizációs eszközök és a rítusok}

„Résztvevő megfigyelést azért érdemes a térhasználatra fókuszálni, mert az általános definíción kívül további jelentések derülhetnek ki a közösség kulturális gyakorlatának értelmezéséhez, a tér attól válik kifejezővé, hogy a benne megjelenő emberek használják, valamilyenné alakítják. A közösség vizsgálatához alapvető szempont, hiszen a tér használatában való részvétel adott minden jelenlévő számára. Különösen akkor lehet kiemelt a tér szerepe, ha a közösség tagjainak rendszeres találkozóhelye" - írja Birkás Anna. (Birkás [2007], p. 83.) Bár e dolgozat központi témája nem a térhasználat, azonban a téma megértéséhez elengedhetetlen ezt is tárgyalni, mivel az elvonulások és így a terepmunka központi helyszíne a közösség szakrális tere volt. A térhez kapcsolódva pedig szót kell ejtenünk a szimbolizációs eszközökről és a rítusokról is.

\subsubsection{A központi, szakrális tér}

A buddhista közösségi gyakorlás és így az elvonulások központi helye, színtere is a zendó, amely a Szelíd Mosoly Buddhista Szangha esetében - mivel nincsen önálló épülete vagy helyisége - egy változó helyszínű, alkalmi tér. Ez az alkalmi tér tölti be ugyanakkor a szakrális tér funkcióját, így az ezzé való átalakítás után a térben új 
szabályok lépnek érvénybe. Leeuw a szent térről értekezve leírja, hogy a hely már az állatok számára sem a térnek valamely tetszőleges pontja, hanem egy támaszpont a világ kiterjedtségében, egy olyan „megszokott hely”, amelyhez igazodnak. A tér egyes részeinek önálló értékük van, ezek lesznek a megszokott helyek, amelyek azáltal válnak megszokottá, hogy kiemelik őket a világ kiterjedtségének egészéből. Az ember felismeri a hely hatalmát, keresni vagy kerülni kezdi, megpróbálja erősíteni vagy gyengíteni, de mindenképpen kiválasztja mint „megszokott helyet”. (Leeuw [2001], p. 342.) A hely megszentelése „azzal kezdődik, hogy a tér egészéből kiemelnek egy bizonyos területet, ezt megkülönböztetik más területektől, és bizonyos mértékig vallásilag körülhatárolják és körülkerítik". A szent teret olyan helyként is lehet definiálni, amely azáltal válik megszokott hellyé, hogy ott tapasztalhatjuk a hatalom megismétlődő vagy az ember által megismételt hatását (Ernst Cassirer, idézi Leeuw [2001], pp. 342-3.)

Eliade mindezt úgy fogalmazza meg, hogy létezik egyfajta szent, vagyis „erővel feltöltött”, jelentőségteli tér, és léteznek más, nem szent terek, következésképpen nincs struktúra és szilárdság nélküli, egyszóval „formátlan” tértartomány. Az, hogy a tér nem homogén, olyan ősélmény, amelyet egyfajta „világalapítással” azonosíthatunk. Itt egy olyan elsődlegesen vallásos élményről van szó, amely megelőz minden a világra vonatkozó reflexiót, mert ez teremti meg azt a „szilárd pontot”, középtengelyt, amelyből minden jövőbeli tájékozódás kiindul. A rituális tájékozódásnak és valamiféle szent tér felépítésének világteremtő jelentősége van. (Eliade [2014], pp. 15-6.)

Ez történik meg az elvonulások során is: a mag már a szervezés során kiválasztja a zendónak megfelelő területet, és az elvonulás napján, még mielőtt a résztvevők megérkeznek, elkezdik berendezni a teret. A tér központi helyére kerül az oltár a Buddha szoborral, mellette egy másik Buddha szoborról készült, keretezett kép, valamint az iskola fő szellemi vezetőjéről, Thich Nhat Hanh-ról készült fotó, illetve a tőle származó idézetek szintén keretezett képeken (3. kép). Ezeken kívül virágok, gyertyák, stólák díszítik az oltárt. A leghangsúlyosabb szín a narancs (sáfrány) és a bordó-barna - a narancsszín szimbolizálja a buddhizmus lényegét: a bölcsességet, az erőt, a legmagasabb szintű tökéletességet, a külvilágról való lemondást és a megvilágosodást. Ez jelképezi a rendnek való elkötelezettséget is, és ez a szerzetesek ruhájának színe bizonyos buddhista irányzatokban, főleg 
Délkelet-Ázsiában, például a théraváda buddhizmusban. A barna szín Japánban és Koreában elterjedt, valamint a vietnami szerzetesek (páli szóval bhikkhuk) és szerzetesnők (vagy apácák, bhikkhunik) is ezt hordják körülbelül kétszáz éve: ez a szín fejezi ki a vietnami emberek erkölcsös és mértékletes életét. ${ }^{80}$

A teremben más helyeken is ezek az elemek ismétlődnek: Thich Nhat Hanh-ról készült képek, tőle származó idézetek, virágok, gyertyák, kendők-stólák kapnak helyet, otthonossá téve a teret (4. és 8. kép). A földre szőnyegek és szivacsok, valamint ülőpárnák kerülnek. A szivacsok elrendezése az adott programtól függően változik (és természetesen a rendelkezésre álló térhez igazodik). A meditációkhoz négy párhuzamos sorba kerülnek, és a gyakorlók úgy ülnek le, hogy két egymás mögötti sor néz egy irányba, a fal, illetve az ablak felé (a középső két sorban ülők tehát háttal ülnek egymásnak, és az előttük lévő sorban ülők hátát látják). A tanító és a tolmács az egyik belső sor szélén ül. A relaxációnál, amikor a résztvevők fekszenek, a célszerűség határozza meg a szivacsok helyét, az a fontos, hogy mindenki a lehető legkényelmesebben elférjen. A Dharma-tanításokhoz több sorban, kissé ívesen helyezkednek el a szivacsok, így a résztvevők az oltár és a tanító felé fordulnak, aki (amennyire a rendelkezésre álló tér engedi) az oltár mellett foglal helyet a tolmáccsal (2. és 8. kép). A szertartásokon az oltár előtt egy sávban, egészen a falig üresen marad a hely, mivel ilyenkor a résztvevőknek, illetve a beavatási szertartáson (az öt éberfigyelem-gyakorlat felvételénél) a beavatottaknak az oltárhoz kell járulniuk. A szivacsok e sáv két oldalán, a sáv felé nézve helyezkednek el egymás mellett és mögött. A tanító és a tolmács az oltárhoz legközelebbi részen, az első sorban ül. Végül pedig a leginformálisabb eseményen, a tea-szertartáson lehetőség szerint körben helyezkednek el a szivacsok, ilyenkor a tanító és a tolmács is bent ül a körben. Minden eseményen az oltárhoz képest két oldalt, leghátul székek is vannak: ide ülhetnek azok, akik számára a földön ülés kényelmetlen/kivitelezhetetlen. A harang a szertartásokon és a meditációkon/relaxáción a tanító előtt van, a Dharma-tanításokon pedig az oltárral szemben, a legelöl, középen ülő előtt - ilyenkor az egyik résztvevő (a harangmester) hívja meg a harangot (2., 3. és 8. kép).

${ }^{80}$ Lásd: http://plumvillage.org/letters-from-thay/the-mountain-rock-cliff-robe/ (Utolsó letöltés: 2016. február 20.) 
Az elrendezés lényeges, mindig a célnak megfelelő: a meditációkon a befelé figyelést és az összpontosítást segíti, ilyenkor a gyakorló maga van a „középpontban”, bárhol is ül; a tanításokon a tanító kapja a főszerepet, ekkor az elrendezés a klasszikus osztálytermi elrendezéshez hasonlít, de ívessége miatt kevésbé szigorú; a szertartásokon pedig az oltár körül zajlanak az események, jelezve a szertartás transzcendens jellegét, és lehetővé téve a transzcendenssel való kapcsolatfelvételt. Az elvonulás záró eseménye, a tea-szertartás kör alakja pedig az egymásra figyelést, egymáshoz kapcsolódást hivatott kifejezni. A zendó berendezését az örömteli munka keretében az egyik család végzi: az aktuális program előtt rendezik át a zendót a megfelelő módon.

A berendezéssel és az oltár felállításával a tér megkapja szakrális jellegét. Ettől kezdve érvénybe lépnek bizonyos szabályok, így például a zendóba való belépés előtt a cipőt le kell venni (6. kép), nem szabad ételt és bögrét/poharat bevinni (flakont/termoszt azonban lehet, a tea-szertartás pedig kivételt képez), valamint belépéskor és kilépéskor meg kell hajolni az oltár felé. A zendó alapvetően csendes hely, a meditációk, a relaxáció és a Dharma-tanítások során csak a tanító beszél (utóbbiakon elhangozhatnak kérdések, közbeszólások, de a kérdések helye alapvetően a kifejezetten kérdezz-felelek formájában megtartott Dharma-tanítás); a szertartásokon a tanító beszéde mellett bizonyos szövegek közös felolvasására és kántálásra, az öt éberfigyelem-gyakorlat felvételének szertartásán pedig a jelentkezők menedékvételére kerül sor. A leghangosabb esemény a tea-szertartás, ez a helye az egyéni vagy közös éneklésnek, versmondásnak, „élménybeszámolónak”, bárminek, amivel a résztvevők szeretnék kifejezni az érzéseiket és gondolataikat. Ezenkívül a beavatás után van némi „hangoskodás”, ilyenkor a szangha tagjai gratulálnak a beavatottaknak, valamint öleléssel fejezik ki az egymáshoz való kapcsolódásukat, együttérzésüket. A beavatási szertartást nevezhetjük az elvonulás csúcspontjának, hiszen a menedéket vevők ilyenkor fejezik ki elköteleződési szándékukat a buddhista tanítások, életvitel és közösség felé. Ennek megfelelően a szertartás emelkedett hangulatú, megindító, így a formális rész után jellemző az érzelmek túlcsordulása.

A rögzített programok közötti időben is lehet a zendóban tartózkodni, egyénileg meditálni, pihenni, akár aludni is. Továbbá itt zajlanak a tanító és 
a családfők megbeszélései, valamint célszerűen valamelyik család Dharmamegosztásai is, mindezek mérsékelt hangerővel.

A zendó tehát az egész elvonulás központi, szakrális tere. Ez a tér nem egy olyan hűvös, borzongató, a transzcendens távoliságát érzékeltető tér, mint amely Leeuw szerint a primitív ember szent helyeit jellemezte: ezeket a helyeket éppen azért emelték ki, mert kiderült róluk, hogy szent helyek, és gyakran ijedtséget keltő erdőket, barlangokat emeltek így ki. (Leeuw [2001], p. 343.) A zendó ezzel szemben bárhol berendezhető, otthonos hely, amelyben gyakorolni, tanulni, pihenni, emlékezni, a transzcendenssel kommunikálni egyaránt lehet. Ugyanakkor a primitív ember ilyen szent helyeiben és a modern kor buddhista zendójában közös, hogy menedékként funkcionálnak: az ausztráliai őslakosok szentélyeiről írja Leeuw, hogy még a környékük is sérthetetlen, ahol nincs helye a vitának, és még az oda menekült sebzett állatot sem üldözik tovább. (Leeuw [2001], p. 345.) A zendó hasonló hely¹, az itt végzett összes tevékenység szakrális szempontból kitüntetett, tekintve hogy minden Buddha „szeme előtt” zajlik. Az, hogy a tér csak ideiglenes, nem csorbítja a szakrális funkció betöltésére való alkalmasságát (miközben természetesen nem összemérhető a buddhizmus hagyományos szent helyeivel). „Mindegy, hogy egy hely szentsége milyen módon lehet »közösségi hely«, a helyet a szentsége emeli az őt körülvevő terület egésze fölé." (Leeuw [2001], p. 347.)

A szent és a profán tér között átmenet van. Eliade hangsúlyozza, hogy a „hívő ember számára a templom más térben áll, mint az utca, amelyben található. A templombelsőbe vezető ajtó arra utal, hogy itt megtörik a térbeli folyamatosság. A két tér között emelkedő küszöb a két létezési mód, a profán és a vallásos közötti szakadékot is jelzi. Egyszerre az a korlát, választóvonal, határ, amely a két világot elválasztja, és az a paradox hely is, amelyen e két világ találkozik, és amelyen létrejöhet az átmenet a profánból a szakrális világba. (...) A küszöb és az ajtó közvetlenül és konkrétan mutatják a térbeli kontinuitás megszűnését. Ebben rejlik

\footnotetext{
${ }^{81}$ Az egyik elvonuláson nehéz perceket jelentett, amikor a zendót megszálló darazsakat kellett valahogyan - nem ártva - eltávolítani. A művelet nem is volt teljes mértékben sikeres. Hasonló vívódását jelezte az is, aki a Magyarországi Karma-Kagyüpa Közösség hitéleti vezetőjével, Láma Csöpellel készített interjút: „Erre való tekintettel Láma Csöpel társaságában nem merem lecsapni a minduntalan rám szálló legyet, pedig egyre szemtelenebb." Lásd: http://www.buddhatar.hu/hu/bevezeto (Utolsó letöltés: 2016. február 20.)
} 
nagy vallási jelentőségük: egyszerre szimbólumai és közvetítői az átmenetnek." (Eliade [2014], p. 18.)

Az elvonuláson az előtér bizonyos átmeneti helyet képezett. Az előtérben lévő egyik asztalon voltak a harangok dekorációval körülvéve, és itt vették le a résztvevők a cipőjüket (5. és 6. kép). Volt egy másik asztal is, ahol dekorációs kellékek, valamint megvásárolható Thich Nhat Hanh-könyvek voltak egy becsületkasszás dobozzal, amelybe a könyvek ellenértékét kellett tenni.

A zendóba való belépéssel és az azt követő meghajlással (az oltár felé fordulva) az ember a szakrális térbe került. A tanító jelenléte érezhetően befolyásolta a magatartást, ilyenkor a résztvevők visszafogottabban viselkedtek, mint amikor a tanító csak később lépett a terembe. Miután mindenki megérkezett és az aktuális programnak megfelelően kényelembe helyezte magát, a harang meghívásával kezdetét vette a program. Minden program így kezdődött, és csendes (akár csak ötperces) üléssel (meditációval) folytatódott, ami a lecsendesedést, a spirituális értelemben vett megérkezést szolgálta. Ezzel a térbeli átlépés mellett egy mentális váltásra is sor került.

\subsubsection{Szimbolizációs eljárások és eszközök}

Ha Geertz nyomán próbáljuk megérteni a szimbólumok szerepét, akkor a közösség ethosza és a világkép megkülönböztetéséből kell kiindulnunk. Geertz azt mondja, hogy:

a „közösség ethosza nem más, mint tagjai életének alapárnyalata, jellege, minősége; morális és esztétikai stílusa, atmoszférája; azaz alapvető viszonyulás saját maguk és az élet által visszatükrözött világ [f]elé. A világkép ezzel szemben a dolgok tiszta megjelenéséből áll össze, azaz a természetről, az énről, a társadalomról alkotott képzetek összessége. Ide tartoznak a rendről vallott legáltalánosabb eszmék is. A vallási hiedelmek és rítusok szembetalálkoznak egymással és kölcsönösen megerősítik egymást. Az ethoszt az teszi az értelem számára felfoghatóvá, hogy úgy jelenik meg, mint valami, ami a világkép által leírt és a dolgok természetes állapotából következő életmódot reprezentálja; a világkép pedig akkor válik érzelmileg elfogadhatóvá, ha a dolgok olyan természetes állapotának képeként kerül megfogalmazásra, amelynek az adott életmód az autentikus kifejeződése. Valamennyi vallásnak lényegi alkotórésze, hogy megmutatja e jelentésgazdag viszonyt az emberek által alkotott értékek és az általuk megélt lét általános rendje között, noha ez a rend és az értékek kigondolt dolgok. Bármi legyen is a vallás, részben mindenképpen egy kísérlet 
- nem annyira explicit és tudatosan átgondolt, mint inkább implicit és érzelmileg megélt próbálkozás - azoknak az általános jelentéseknek megőrzésére, melyek alapján minden egyes individuum értelmezi saját tapasztalatait, szervezi viselkedését." (Geertz [1994a], pp. 7-8.)

E jelentéseket csak a szimbólumok tárolhatják, és a vallási szimbólumok a fogékonyak számára a rituális cselekményben magukba sűrítik, ami tudható a világról, a világból eredő érzelmeket és azt, hogyan kell a benne élőnek cselekednie. A szent szimbólumok ilyenformán az ontológiát és a kozmológiát kötik össze az esztétikával és a morállal; különleges erejük pedig abból származik, hogy képesek a tényeket az értékekkel a legmélyebb szinten azonosítani, valamint azt, ami egyébként tisztán létező, átfogó, normatív jelentőséggel felruházni. A vallási rendszer így nem más, mint a szent szimbólumok kerek egésszé rendezett kalauza. A szimbólumok nemcsak pozitív értékeket jeleníthetnek meg, hanem negatívakat is, a rossz létére, valamint a jó és a rossz közötti konfliktusra is felhívják a figyelmet. Az, hogy egy vallás mennyire képes a társadalmi értékeket támogatni, azon múlik, mennyire képes szimbolikus megfogalmazását adni egy olyan világnak, amelynek ezek az értékek alapvető tartozékai. (Geertz [1994a], pp. 8-13.) Pete-P. Szilczl Geertz nyomán úgy foglalja ezt össze, hogy az intézményekben mint kulturális rendszerekben az emberek a szimbolikus formákban kifejezett, örökölt (azaz történelmileg közvetített) koncepciók (jelentések) segítségével kommunikálnak, állandósítják és fejlesztik az élettel kapcsolatos tudásukat és attitűdjeiket. Ezeknek a - szimbólumok révén közvetített - koncepcióknak az a funkciójuk, hogy szintetizálják azt a képet, amelyet a társadalom tagjai a valóságban létező dolgokról fenntartanak, a szimbólumoknak pedig az feladatuk, hogy a világkép által leírt dolgokat összeegyeztessék a csoport vagy társadalom tényleges helyzetével. Ezt azáltal érik el, hogy objektívvé tesznek bizonyos preferenciákat, és ezeket a preferált tényezőket egy adott struktúrájú világ magától értetődő feltételeiként írják le. A hangsúly ezért a kulturális rendszereken belül zajló szimbolizációs eljárásokra és magukra a szimbólumokra kerül. (Pete-P. Szilczl [2006], pp. 30-1.)

Fentebb már említés esett arról, milyen jelentés társítható az oltáron használt színekhez, most pedig két, a buddhista gyakorlatban használt szimbolizációs eszközről, a harangról és a füstölőről, valamint a hozzájuk kapcsolódó rítusokról lesz szó. 


\subsubsection{A harang meghívása}

A harang kitüntetett szerepet kap a buddhista rituáléban: a hangja Buddha hangja, aki hazatérésre szólít. Emellett az univerzum rendjét fenntartó Dharma (tan, törvény) hangját is szimbolizálja. Trías hangsúlyozza, hogy a szimbólum mindenekelőtt nem tárgy vagy dolog, ezért az ilyen vagy olyan szimbólum helyett helyénvalóbb szimbolikus eseményről beszélni. A szimbolikus esemény akkor valósul meg, amikor a szimbolizáló forma mint a szimbólum kézzelfogható és megjeleníthető (látható, érzékelhető, hallható) aspektusa és a szimbólumban fellelhető szimbolizált forma (amely a szimbólum jelentéshorizontját képezi) közötti szakadás (szétválasztottság) megszűnik azzal, hogy e két fél (mint egy érme két szétválasztott fele) az eseményben találkozik és összeillik. Ezen összekapcsolódásnak feltételei vannak. Egyrészt a szimbolizáló rész létrejöttéhez szükséges az, hogy anyagi szubsztanciája legyen, amely rendezett és szervezett az őt leíró tartományban (ezt világnak vagy kozmosznak hívjuk), és ez a kozmosz úgy legyen elrendezve, hogy lehetővé tegye a meghatározott (a szent) és az ennek létezéséről tanúskodó határozott (emberi) tanú találkozását; továbbá ezt a találkozást vagy tanúságtételi viszonyt (szóbeli vagy írásos) kommunikációval meg lehessen erősíteni. Másrészt a szimbolizált tekintetében a jelen lévő szimbólumnak utalnia kell azokra a hermeneutikai kódokra, amelyek lehetővé teszik az (ideális) alakok létrehozását, amelyek révén elnyerheti pontos jelentését, és a szövegmagyarázó kulcsoknak kell hogy legyen egy felső határuk, amely a jelentéssel kapcsolatos minden további vizsgálódást aláás, és amely bizonyítja, hogy a továbblépés csak misztikus formában lehetséges. (Trías [2006], pp. 197201.)

A harang meghívása (inviting the bell) tehát egy szimbolikus esemény, egy fontos tevékenység, amit jelez az is, hogy csak olyan ember teheti, aki elég „szilárd” a harang meghívásához, amit nem szabad elkapkodni: a „harangmester” (az a személy, aki aktuálisan meghívja a harangot) néhány pillanatig (ameddig szükséges) csendben meditál, lecsendesedik, hogy elérje a megfelelő tudatállapotot. A harangmester lehet a tanító, illetve a tanító által kijelölt személy - a felkérés megtiszteltetést jelent. Egy Thich Nhat Hanh tanításainak szellemében működő 
amerikai szangha ${ }^{82}$ úgy jellemzi a harangot, hogy az a szangha szeretett tagja, egy jó barát a gyakorlásban. Buddha hangja, amely hazatérésre szólít - hazatérésre a saját testbe, a saját életbe, a jelen pillanatba. A harangot 'meghívják' (invite), nem pedig 'megütik' (strike), mivel utóbbi erőszakot sugall, az előbbi ezzel szemben tiszteletet és békét. A harangmesternek sokat segít, ha rituális kapcsolatot alakít ki a haranggal, valamint fontos, hogy a „barát” meghívása előtt lecsendesítse az elméjét. A harang felemelése előtt a szilárd állapot eléréséhez egyenesen kell ülni, és hármat lélegezni. Majd a szív magasságában lótuszba kell tenni a kezeket. A testnek és az elmének a tisztelet állapotába kell kerülnie a harang meghívásához. A megszólaltatás előtt meg kell hajolni a harang előtt, mivel a harang maga Buddha. ${ }^{83}$

\subsubsection{A füstölö felajánlása}

A buddhista gyakorlatban bevett dolog különféle dolgokat, pl. ételt, ivóvizet, fürdővizet, virágot, gyertyát, füstölőt felajánlani. A felajánlás alapvetően „a három ékkőnek”, a Buddhának, a Dharmának és a Szanghának szól, és különböző rítusok, szertartások alkalmával történhet meg. Fő célja az olyan érdemek felhalmozása, amelyek hozzásegítenek az önfegyelemmel elérhető tökéletesség felismeréséhez. Mielőtt azonban rátérnénk a konkrét rítusra, szükséges megadni a 'rítus' meghatározását.

\subsubsection{A rítus különféle megközelítései}

A rítus szociológiai értelemben egy olyan, gyakran ismétlődő mintázatú viselkedési forma, amelyet - szimbólumok használatával - a megfelelő időben hajtanak végre. A rítusok alkalmazásának egyik fő társadalmi területe a vallás, azonban a nem vallásos és mindennapi életben is megjelennek, így például a mindennapi viselkedés kapcsán beszélhetünk olyan rituális kódokról, amelyek révén az egyes aktorok képesek együttműködni egy közös valóság elismerésében, valamint képesek fenntartani identitásukat.

\footnotetext{
${ }^{82} \mathrm{Az}$ oregoni Five Stones szangha.

${ }^{83}$ Lásd: http://www.fivestonessangha.org/Home/inviting-the-bell
} 
Durkheim szerint a vallási jelenségek két alapkategóriára oszlanak: hiedelmekre és rítusokra. „Az előbbiek, melyek véleményállapotok, képzetekből állnak; az utóbbiak meghatározott cselekvési módok." (Durkheim [2004], p. 44.) Valamennyi vallási hiedelem közös jegye az, hogy a képzeteket két osztályba sorolja, a szentbe (szakrális) és a profánba. A rítusokat a tárgyuk speciális természete alapján lehet megkülönböztetni a többi emberi - erkölcsi - szokástól: a „rítusok olyan magatartásszabályok, amelyek előírják, miként kell viselkedniük az embereknek a szent dolgokkal szemben. Ha bizonyos számú szent dolog oly módon áll egymással mellé- vagy alárendeltségi viszonyban, hogy összességében bizonyos egységet képez, ám ez az egység a maga részéről semmi más hasonnemű rendszerbe nem tartozik bele, akkor a hiedelmek és az ezeknek megfelelő rítusok összessége vallást alkot." (Durkheim [2004], pp. 44-8.) Durkheim követői azt hangsúlyozzák, hogy a rítusok társadalmi szolidaritást teremtenek, ami elengedhetetlen a társadalom szövetének fenntartásához. Durkheim annak állításával, hogy az emberek a rítusokon keresztül tudják pontosan kifejezni a társadalmi kapcsolatok mintázatait a maguk számára, a rítusokat a társadalmi struktúrára redukálta. Számára a rítus szignifikáns alapegysége a tevékenység, mivel az hiteket eredményez, fordítva azonban ez nem mondható el. Tehát a rítusnak elsődlegesen episztemológiai szerepet tulajdonított, ragaszkodva ahhoz, hogy a gondolkodás szükséges építőkövei a rítus segítségével megosztott „pezsgésen” keresztül továbbítódnak. A szociológiai megközelítéssel szemben gyakran hozzák fel azt, hogy a rítusok elemzői nagymértékben az események saját maguk általi értelmezésére támaszkodnak. Gilbert Lewis szerint a rítusok jelentésének keresése elfedi azokat a megfontolásokat, hogy maguk az emberek mit éreznek a rítusok során - tehát nem törődik a jelenség emocionális oldalával. Lewis azt hangsúlyozza, hogy a rítusok értelmezésekor a kutató meglátásai mellett azt éppúgy figyelembe kell venni, hogy mit jelentenek ezek a résztvevők számára. (Marshall [1998], pp. 569-70.)

Ha például az etológiai nézőpontot vesszük, a szerint akkor beszélünk rítusokról, amikor a viselkedés és a szabálykövetés összekapcsolódik az emberben működő érzelmi mechanizmusokkal. A szabálykövetés és egy rítus elvégzése között nagyon sok a hasonlóság, a rítusban azonban több az érzelmi töltet, a hiedelem és a véletlenszerűség, a megszokás, míg a szabálykövetés sokszor visszavezethető egyszerű logikai műveletekre, és mindig külső beavatkozással, tanítással, 
fegyelmezéssel kapcsolatos viselkedést jelent. A rítusok kialakítása és követése fontos összetartója és tudáshordozója volt az ősi emberi társadalmaknak: a pontosan követett viselkedési szabályokkal végzett rituális szertartás alkalmas arra, hogy minden generáció újra és újra ugyanolyan módon élje meg. A rítus viselkedési szabály, felfokozott érzelem és szimbólum szétválaszthatatlan, önálló jelentéssel bíró egységben. (Csányi [2000])

Thich Nhat Hanh is az érzelmekre helyezi a hangsúlyt, és azt írja a rend szertartásait és énekeit tartalmazó, Chanting From the Heart című könyvében, hogy „amikor énekelünk [chant], a szívünkből énekelünk. Nem »előadunk« [performing] egy istenségnek vagy valaki másnak. Nemcsak végrehajtjuk a rítust, miközben a szánk úgy tesz, mintha végezné azt, de az elménk valahol máshol van. Azért alkottuk meg ezeket a szövegeket és zenéket, hogy a Dharma eszközeiként szolgálhassanak, hogy segítsenek nekünk visszatérni a bennünk rejlő legmélyebb helyhez, ahhoz a helyhez, ahol a leginkább felébredettek és elevenek voltunk. Az éneklés gyakran a legközvetlenebb és legkézenfekvőbb módja az e hellyel való újrakapcsolódásnak." (Nhat Hanh [2007], p. 11., fordítás: H. O.)

\subsubsection{Rituális nyelvhasználat}

A rituális nyelv természetét a természeti népek kultúrájában már többen is próbálták magyarázni (S. J. Tambiah, R. Finnegan, B. Ray, S. D. Gill), mindannyian Austin beszédaktus-elméletéből kiindulva. Malinowski bebizonyította a rítus verbális komponenseinek fontosságát, a későbbi irodalom pedig újra rámutat a szavak rituális jelentőségére, arra, hogy a szavak kimondása már önmagában is rítus. A rítusok a verbális formulák egész sorát használják fel, amelyeket imának, dalnak, ráolvasásnak, áldásnak stb. nevezünk. A rítusban azonban a nyelv megsérti a definíció szerinti kommunikatív funkciót, például amikor olyan nyelven zajlik a rítus, amelyet a résztvevők nem értenek. Ugyanakkor a rítus kommunikációelméletének egyik fontos megállapítása, hogy a rítusban az emberek önmagukról önmaguk számára szólnak, ami ellentmondáshoz vezet. Mivel a rítusban sajátos nyelvhasználat érvényesül, a szintaktikai és más nyelvi szabadság korlátozott (pl. egy a gyógyulás érdekében elmondott navajo ima szavait tökéletesen pontosan kell kiejteni). A nyelvi kommunikáció szokásos formáinak megváltozása 
miatt a rítusban nem feltételezhetjük a szokásosabb kommunikációk szemantikai folyamatát. A résztvevők ilyenkor a mindennapival ellentétben formalizált beszédet és éneklést alkalmaznak, a formalizáció pedig a kimondottat eltávolítja nemcsak a meghatározott időtől és helytôl, hanem az illető beszélőtől is. (Lovász [2002], pp. 168., kiemelés: H. O.)

Talán éppen ez utóbbi szempont az, ami miatt Thich Nhat Hanh ebben a tekintetben is eltérő álláspontot fogalmaz meg: számára éppen az „itt és most” levés, a személyes kapcsolódás a fontos. A fentebb idézett helyen azzal folytatja, hogy a „Chanting From the Heart [szívből való éneklés] nem igényel speciális tudást. A szanszkrit és páli szavak és más buddhista terminusok magyarázatát a könyv végén lévő szószedet tartalmazza. A szanszkrit szavak »c« betűjének kivételével (amelyet ch-nak kell ejteni) a szavakat rendszerint fonetikusan kell kiejteni. Arra bátorítunk [invite], hogy kreatívan használd a könyvet, a tartalmát pedig igazítsd a saját és közösséged gyakorlásához. Arra kérünk, hogy nyugodt és szelíd hozzáállással, nyitott elmével és befogadó szívvel gyakorolj." (Nhat Hanh [2007], pp.11-2., fordítás: H. O.) A szertartások, rítusok tekintetében az általam megkérdezettek is inkább az érzelmi, nem pedig a szabálykövetési/nyelvhasználati dimenziót hangsúlyozták (lásd alább a „Mit jelentenek a szangha rítusai, szertartásai a résztvevők számára?" című fejezetben). Az egyik interjúalany a jógatáborban (ez is egyfajta elvonulás) szerzett szertartásélményeivel kapcsolatban az alábbiakat mondta:

„A jógatáborban is vannak szertartások, de azokat nem szeretem annyira. Van reggeli ima, amikor 25 percig szanszkritul énekelnek minden reggel fél hattól, az egy horror, én nem tanultam meg ezeket. Volt, hogy elkezdtem tanulni szanszkritul, de aztán abbahagytam. Nekem ez abszurdum, hogy felnőtt emberek kívülről megtanuljanak egy olyan szöveget, amit nem értenek szóról szóra, nekem ez akkora fanatizmus. Vagy amikor ezek a bhadzsan ${ }^{84}$-éneklések vannak, ami szintén nem a szívem csücske, akkor ezeket is éneklik fejből, ezek hosszúak, és nem is értem, hogy tanulták meg - én nem tudok megtanulni valamit kívülről, ami hosszú, és amit nem értek." (Nikolett)

${ }^{84}$ Szanszkrit (hinduizmus): bhajan/a. Az istenség vagy egy avatara (isteni tudat) zenével és énekkel kísért szertartása. (Hetényi [1997]) 


\subsubsection{A felajánlási rítus}

A tibeti buddhizmusban a füstölő felajánlása során az embereknek meg kell vizsgálniuk motivációjukat: a lámáknak, meditációs istenségeknek vagy védőszenteknek való felajánlásból felhalmozott érdemeknek minden érző lény javát kell szolgálniuk. Ha a felajánlónak valamilyen konkrét kérése van (mint amilyen például a vallási gyakorlás előtt tornyosuló akadályok eltávolítása), akkor ezt is itt kell megtennie. A felajánlás után a gyakorló menedéket vesz, illetve meditál a négy erényen (a négy mérhetetlenen) - ezek a jóság/kedvesség (szanszkrit: maitrī, páli: mettā), az együttérzés/részvét (szanszkrit/páli: karuṇā), az öröm/együtt érző öröm (szanszkrit/páli: mudita) és

az egykedvűség/pártatlanság/közömbösség/felülemelkedettség (szanszkrit: upekṣā, páli: upekkhā). A meditáció, gesztusok és mantrák rítusa révén a felajánlott tárgyak megszentelődnek, megszabadulnak hétköznapi megjelenési formájuktól, és a boldogság kimeríthetetlen forrásaivá válnak a felajánlók számára. A felajánlás végén a gyakorlók arra kérik az istenségeket, hogy bocsássák meg azokat a hibákat, amelyeket a rítus elvégzése során vétettek, például ha helytelenül vagy hiányosan recitálták a szövegeket. A füstölőfelajánlás célja itt a hála kifejezése az istenségek felé, ilyenkor vallási rítus keretében történik meg; ugyanakkor egyszerübben is elvégezhető, ha a hagyománynak megfelelően a levegő megtisztítására használják. Emellett a buddhista gyakorlatban a halotti rítusnak is részét képezi. ${ }^{85}$

A föld három érintése gyakorlathoz kapcsolódva Thich Nhat Hanh a következőket írja a füstölő felajánlásáról:

„Amikor elkezded gyakorolni a három leborulást, akkor rendszerint bemész a meditációs terembe, vagy odalépsz a családi oltárhoz, és amint leülsz és meggyújtod a füstölőt, rögtön érezheted az együvé tartozás békéjét. Kezedbe veszel egy füstölőpálcát, a figyelmedet rá irányítod, fogsz egy gyufát, és meggyújtod a füstölőt. Mindezt tudatossággal végzed. Amikor a spirituális vagy a vér szerinti őseink számára szeretnénk füstölőt felajánlani, akkor rendszerint a homlokunkhoz emeljük a füstölőt. Homlokunk jelképezi a spirituális értékek iránti tiszteletünket. A test minden része képvisel valamit. A kultúránkban, nemcsak Ázsia, hanem a Nyugat népei számára is, a homlokunk, a fejünk azt a szándékunkat képviseli, hogy tiszteljük és nagyra becsüljük az életünknek értelmet adó értékeket. Melyek ezek az értékek? A béke, a nyugalom, annak

85 Lásd: Me-Long, The Newsletter of the Council for Religious and Cultural Affairs of His Holiness the Dalai Lama, No.6, April 1990. http://www.sacred-texts.com/bud/tib/incofr.htm (Utolsó letöltés: 2016. február 20.) 
képessége, hogy boldogok legyünk, a megértés, az elfogadás és a szeretet képessége. Ezek valós dolgok, amelyeket az emberiség nagy családjának képviselői kifejezésre juttattak. Őseink bebizonyították, hogy sokan közülük képesek a szeretetre, a megértésre, a boldogságra. Elismerjük ezeket az értékeket a fejünkkel, amikor meghajlunk. Tudjuk, hogy bennünk vannak, így amikor meghajlunk minden ősünk felé, akik megtestesítik ezeket az értékeket, egyben magunk felé is meghajlunk, mivel mi is birtokoljuk őket. Meghajlunk a gyerekeink és az ő gyerekeik, unokáik felé is, mert ők is birtokolják ezeket az értékeket. Így amikor meghajtjuk a fejünket, akkor meghajolunk a múlt, a jelen és a jövő felé egyaránt.

Amikor meghajolsz, nem egy bizonyos személy felé hajolsz meg, hanem ezen értékek felé fordulsz. Összeköttetésbe lépsz a múlttal, a jelennel és a jövővel. Tudod, hogy csak egyetlen irányba kívánsz haladni: a harmónia, az egység, az együvé tartozás, a béke irányába. Az érzés, hogy van egy irány, amerre haladhatsz, éppen abban a pillanatban is megszülethet. Az emberek szenvednek, mert nem hisznek semmiben. Ha tudod, hogy melyik irányba mész, akkor sokkal kevésbé fogsz szenvedni." 86

A Szelíd Mosoly Buddhista Szanghában az Ősök-szertartáson és a vasárnap reggeli menedékvételnél kerül sor a füstölő felajánlására ${ }^{87}$.

\subsubsection{A menedékvétel}

Ahhoz, hogy valaki gyakorolhassa a buddhista tanításokat, a buddhizmus tanainak megfelelő életet élhessen, illetve erre törekedhessen, nincs szükség a buddhizmus formális felvételére, azonban a menedékvétel révén lesz az ember „buddhista”. Nem feltétel, hogy a menedékvétel egy tanító által vezetett formális szertartás keretében

\footnotetext{
${ }^{86}$ Lásd: http://www.szelidmosoly.hu/index.php/tanitas/gyakorlatok/19-a-fold-harom-erintese

${ }^{87}$ A füstölőfelajánlás Thich Nhat Hanh közösségeiben használt angol nyelvű szövege (1. verzió) - ez hangzik el a Szelíd Mosoly szertartásain is (a többi dal és szertartás megtalálható ebben a könyvben: Thich Nhat Hanh and the Monks and Nuns of Plum Village: Chanting From the Heart):

[Bell, Bell, Bell]

In gratitude, we offer this incense

Through our space and time

to the Buddhas and the Bodhisattvas

May it be fragrant as Earth herself

reflecting careful efforts

wholehearted awareness,

and the fruit of understanding slowly ripening.

May we and all beings be companions

of Buddha and Bodhisattvas.

May we awaken from forgetfulness

and realise our true home.

[Bell]
} 
történjen meg, azonban megvannak azok az előnyei, hogy egyrészt így a gyakorló önmaga számára is kifejezheti elkötelezettségét, másrészt megkapja a Buddha, a Dharma és a Szangha spirituális támogatását a gyakorlásához. Ebben az esetben magát a szertartást egy írásos jelentkezési kérelem előzi meg, amelyben a jelentkező vázolja indokait és kifejezi elköteleződési szándékát. Ebben a kérelemben megjelöli, hogy az öt éberfigyelem-gyakorlat közül melyeket kívánja felvenni; lehet akár csak egyet is, de mivel ezek a gyakorlatok összefüggenek, ajánlott és érdemes mindet felvenni. Jan Boswijk említette, hogy a tapasztalatai szerint ha valaki egyet kihagy (pl. mert teljesíthetetlennek tartja), a következő időszakban mégis főleg azt fogja gyakorolni. A kérelemben a jelentkező ezenkívül megjelöli, hogy szeretne-e Dharma-nevet kapni. Ha igen, a jelentkezésében leírt motivációk és a tanító vele kapcsolatos benyomása alapján a tanító választ neki nevet, amely „tartalmazza” a gyakorló feladatát is. Más esetekben, amikor nincs kapcsolat a tanító és a jelentkező között, a kapott Dharma-név inkább az adott tradíciót/hagyományvonalat tükrözi.

A menedékvétel szertartása az egyes iskolákban hasonló, kisebb eltérések előfordulhatnak. A szertartás előtt a jelentkező meditációval, önvizsgálattal felkészül az elköteleződésre. A két pannonhalmi elvonuláson a szertartást megelőző este a tanító összehívta a jelentkezőket, és adott néhány gyakorlati információt a szertartás menetéről, azonban nem túl sokat - mivel a szertartás alatt úgyis minden teendőt mond a maga idejében, a „magolás” csak felesleges stresszt eredményezne. A gyakorló dolga csak az, hogy „lélekben” felkészüljön a másnapi szertartásra, lecsendesítse elméjét.

Reggel a szertartáshoz berendezett zendóban összegyűlt a teljes szangha (az elvonuláson lévők). Fontos, hogy mindenki jelen legyen a szertartáson, hogy a menedéket vevő a teljes közösség spirituális támogatását megkaphassa. A menedékvétel előtt sor került a füstölőfelajánlási rítusra: ezt két gyakorló végezte, akiket előző nap választott ki a tanító, és a szertartás előestéjén főpróbát tartottak. A felajánlás a közös gyakorlás (meditáció, recitálás) után következett, mielőtt a menedéket vevők elfoglalták helyüket az oltár előtti, szabadon hagyott sávban. A rítus egyik, a tanító által hangsúlyozott fontos eleme a sietség kerülése, ugyanakkor itt is (és általában a szangha rítusainál, szertartásainál) igaz az, hogy nem elvárás a 
hibátlan elvégzésük. ${ }^{88} \mathrm{Ez}$ a megengedő attitűd lehetővé teszi, hogy a résztvevők (különösen a teljesen kezdők) szorongás nélkül vehessenek részt ezeken az eseményeken.

A következőkben a menedéket kérők elfoglalták helyüket a középső részen, és válaszolniuk kellett az elköteleződést kifejező kérdésekre. Elköteleződésüket leborulásokkal is megerősítették. Végül megkapták a Dharma-nevüket is tartalmazó tanúsítványt a gyakorlatok felvételéről (ebben a gyakorlatok szövege is szerepel), és meghajoltak az oltár előtt. Az emelkedettség „feloldásaként” a szertartás után a szangha tagjai megölelik egymást, ezzel is kifejezve a gyakorlatokat felvevő új tagok befogadását.

\subsubsection{Az Ösök-szertartás}

A szertartás a vér szerint és spirituális ősök előtti tisztelettétel, a nekik való hálaadás szertartása. Előkészületként a szertartáson részt vevők fényképeket visznek magukkal az elvonulásra őseikről. A fényképeket a szertartás napján kell elhelyezni a zendóban a kijelölt helyen, az oltár két oldalán (7. kép). Az esti szertartás rövid csendes meditációval kezdődik, majd különféle rituális szövegek felolvasása és kántálás következik. A Szív szútra nyitóversének közös felolvasása és a kántálás Avalókitésvara, a nagy együttérzés bódhiszattvája meghívására ${ }^{89}$ szolgál. A szertartás célja az ember őseivel való egységének felismerése, hibáik és jóindulatuk megértése, a nekik való hálaadás. A ceremónia végén a gyakorlók sorban az oltárhoz járulnak, gyertyát gyújtanak, amelyet elhelyeznek őseik képei előtt. Az esti, sötétben végzett, gyertyás szertartás nagyon megindító, ezért aki akar, a zendóban maradhat utána is a kívánt ideig. Ez az az este az elvonuláson, amikor a résztvevők a leginkább betartják az estétől reggelig tartó nemes csendet. A 2014-es szertartás - egy a szangha két tagjának rokonságában az elvonulás ideje alatt bekövetkezett haláleset miatt - különösen megindító volt, a hatását másnap egész nap érezni lehetett: a résztvevők ezen a napon jóval csendesebbek voltak.

\footnotetext{
88 Jan Boswijk mondta a 2015-ös nyári elvonuláson: „Aki tökéletes lesz, a szemem elé ne kerüljön!”

89 Namo Avalokiteshvara Chant - a Plum Village-i szerzetesek előadásában megtekinthető és meghallgatható itt: https://youtu.be/ntBfYFFlbV8 (Utolsó letöltés: 2016. február 20.)
} 


\title{
3.3 Mit jelentenek a szangha rítusai, szertartásai a résztvevők
}

\section{számára?}

Az elvonuláson történő megfigyelésből és az interjúkból az rajzolódott ki, hogy a szertartások változatos mértékben érintik meg a résztvevőket, és ez a személyiségtől és az aktuális lelkiállapottól egyaránt függ. A szangha tagjai (illetve az elvonulás résztvevői) általában szeretik a szertartásokat, rítusokat - volt, aki a kezdeti idegenkedését leküzdve barátkozott meg velük. Vannak, akik nem veszik túl komolyan a szertartások szakrális jellegét, és inkább az érzelmi vagy közösségépítő funkciójukat hangsúlyozzák, és van olyan is, aki teljesen átéli a szakralitásukat. Az alábbi megkérdezettek a szertartások - amelyek nem is kell hogy vallásiak legyenek - emberi létmódban való általános szerepét hangsúlyozták:

\begin{abstract}
„A szertartások nekem semennyire nem fontosak, a berendezést például megcsodálom mint esztétikai élményt, örülök, ha jól érzem magam benne, de nem az én területem, nem izgat. Szeretem a szertartásokat, az étkezéseket, szívesen veszek részt rajtuk, de nem válok függővé tőlük, egyszerűen jól érzem magam. Ez egy olyan emberi tevékenység, amit többet kéne üzni, ahogy a természeti népeknél sok szertartás volt, nekünk is több kéne, mert ez egy alap emberi tevékenység, az emberi természet fontos eleme, és egyáltalán nem jó, hogy ebből kevés van." (Péter)
\end{abstract}

„Nincs velük bajom, a szertartások jó dolgok, például egy doktorrá avatás fontos dolog, az a koronaékszer - a szertartás az, amit azért kapsz, amit teljesítettél. Szóval kellenek. Ha valakinek fontos a kapcsolódás, akkor tenni kell, például néhány templom előtt keresztet vetek, pedig máskor nem szoktam, de itt fontos a kapcsolódás. A szertartás olyan dolog, ami valahova odavisz, ha öszintén csinálod." (Erzsébet)

„Magam sem tudom pontosan, mi az a zen, de azt látom, hogy nagyon a tapasztalatra helyezi a hangsúlyt, vannak is benne szertartások, de nincsenek is, tehát nem olyan nagy hangsúllyal, meg nem okoskodunk. Nekem az okoskodás sincs ellenemre, meg a szertartás sincs, de úgy egészségesen tartja, tehát annyi, amennyi a pszichének kell, annyi kerül bele a szertartásból is, mert arra szükség van, meg az okoskodásból is. Nagyon elégedett vagyok az arányukkal. Úgy kipróbálnám azért egyik vagy másik végletet, de szertartás nélkül nem jó." (Gábor)

Többen ambivalensen viszonyulnak a szertartásokhoz, és az interjúk során az is kiderült, hogy ebben sokszor a korábbi tapasztalatok vagy a kötelezőség érzése képviseli a negatív oldalt, de kikövetkeztethető az is (nem feltétlenül az alább szereplő interjúrészletekből, hanem a beszélgetések egészéből), hogy az 
intimitással való viszony is befolyásolja a szertartások megélését. Ugyanakkor egyértelműen megfigyelhető az is, hogy idővel változhat a szertartásokkal kapcsolatos attitűd. A ceremóniák hossza és mennyisége fontos, a többség mindamellett megfelelőnek érzi a különböző elemek arányát az elvonulásokon.

„Nem tudok viszonyulni a ceremóniákhoz, meg van egy csomó babona, azokhoz sem. Az Ösök-szertartás nagyon megrendítô volt, de a beavatáshoz megint nem nagyon tudok viszonyulni. A leborulás eleinte nagyon zavart, amikor elkezdtem a buddhista dolgot, de most már nem zavar. Akkor adott valamit, amikor elöször nem zavart, akkor éreztem azt, hogy ez egy minőségi különbség, hogy nem szégyellem, hogy most itt leborulok, most viszont már mindegy. (...) A tibetiben az volt a bajom, hogy túl sok a ceremónia, az nekem annyira nem jön be." (Boglárka)

„[Egy másik szanghában] jobban benne vannak a szabályok, rítusok, púdzsák. ${ }^{90}$ A nem túl hosszú púdzsákat szeretem. Ott ezek szigorúbbak. Szeretem a ceremóniákat, de nem hosszan." (Ádám)

„Azt mondják, a nyugati embernek azért jobb a tibeti buddhizmussal kezdeni, mert ha megcsinálta azt a 10 ezer leborulást, az felkészít arra, hogy amikor odajut, felébressze benne az elszántságot." (Balázs)

„[Kellenek] azok a keretek, hogy akkor ott megtörténnek szertartások - át kellett gondolnom magamban azt is, hogy vagyok a szertartásokkal, mert gyerekkoromban a szertartásokat is utáltam (ugyan nálunk nem voltak nagy vallásos szertartások, hanem olyan szertartások voltak, hogy vasárnapi ebéd pontban délben, harangszó, és »Jó ebédhez szól a nóta«, utáltam). Például ami itt a szanghában ért, az az, hogy bizonyos szertartásoknak a hangsúlyait máshova tudtam tenni, elkezdtem magam beleengedni, jó volt, megtartott, ott volt benne az, hogy ha éppen nem akarok odamenni, és nem akarok minden reggel felkelni, akkor nem megyek oda, és ez, mondjuk, szerintem a szanghából jön inkább, ez a fajta megengedés. Vagy lehet, hogy a Janból jön inkább, ezt nem tudom, de az, hogy én dönthetek arról, hogy ott vagyok-e egy szertartáson éppen, vagy sem, hogy megmondhatom magamnak azt, hogy nekem most mi a jó, az szerintem nagyon fontos. És nem élek vissza vele, meg nincs semmi ilyesmi, de elkezdtem magamban a szertartásokat úgy átértékelni, hogy megtalálom benne az értéket, hogy miért fontos. És valamikor megérint nagyon egy szertartás, valamikor kevésbé. Mindenki az Ősök szertartását mondja, volt, amikor rettentően ott voltam benne, és nagyon megérintett, a mostani, ami volt, az nem. És ebben is benne van az, hogy nem kell, hogy mindig minden ugyanúgy hasson rám, mert az, hogy mi jön át, milyen gondolat jön át, hogy mi érint meg, az annyira személyes." (Judit)

„Ami érdekes, hogy nekem a szertartásokkal szemben van ellenállásom. De bárhova megyek, nekem ezek a szertartásos jellegű dolgok valahogy nem

${ }^{90}$ Púdzsá (páli és szanszkrit: pūjā): tisztelet, hódolat. 
[jönnek be]. De mindent végigcsináltam, mert amúgy meg érdekel. Fura a kapcsolatom ezekkel. [A menedékvételt] úgy mosolyogva, hogy én ezt végigcsináltam. Maga a szertartás közben nagy elköteleződést éreztem, viszont nagyon fájt a lábam, egy ponton azt hittem, nem fogok tudni megmozdulni. Meg hogy miért néznek, ezt nem lehetne-e úgy, hogy nincs itt ennyi ember. De próbáltam bensőbben megélni, és ez nagyon jó vagy pozitív élmény volt." (Viktória)

Az alábbi interjúrészlet számos szempontból nagyon érdekes: az útkeresés, a többes vallási identitás, a szertartásokkal kapcsolatos szintén sokrétű viszony, a vallások összeegyeztetése (pl. a tabu) és a szakrális tér szerepe is megjelenik benne:

„Lehet, hogy ilyen szempontból a legerősebb identitásom az a buddhista vagy a szanghához köthető, mert ott soha nem érzem azt semmilyen körülmények között, hogy valami nincs rendben, tehát nem érzem, hogy túlzott vagy mesterkélt. Azért egy zsinagógában én néha úgy röstelkedem magam előtt, hogy így bohóckodom, vagy ha néha betalálok egy katolikus templomba valakivel, akkor van a tanítás, és ott is tud nagyon azonos pillanatom lenni, hogy igen, Jézus, és utána rögtön az, hogy nem fogok itt hajbókolni meg hajlongani meg csókolgatni. A zsidó szertartások közül nem mind ilyen, ott vannak ilyen azonosak. Nem tudom, hogy a szertartásokkal van-e baj, de a buddhizmusban meg nincs semmi ilyen, pedig azért nekem az egy nagy törés volt, hogy »ne csinálj magadnak faragott szobrokat«. Tehát nekem a Buddha szobor felé meghajolni azért az egy nagy tabu, de meghajlok, és semmi bajom nincs vele, sôt hiányzik. A hajlongás állandóan hiányzik, az olyan jó, imádok hajlongani. Abszolút átérzem ilyenkor azt, hogy a saját Buddha természetem felé is meghajlok, hogy egyek vagyunk. Az emberek felé nem ment annyira nehezen a hajlongás, hanem a faragott bálvány felé, de nem maradt belőle semmi. Viszont a jógában is ott van Visnu/Krisna, az előtt nem hajolok meg. Lehet, hogy ott is megszoknám, de az egy faragott bálvány nekem. Elöször nagyon nehéz volt, hogy ez elött nem szabad meghajolnom, és nyilván nem várta el a kutya sem, de hogyha nekem úgy kéne belépnem a zendóba a pulcsimért, ha, mondjuk, ott felejtem a pulcsim, hogy nem hajolok meg a Buddha szobor felé, akkor az fájna. Nem lépek be így, az egy szakrális tér. Az elején úgy éreztem, hogy ez tényleg bűn volt, hogy a faragott szobor előtt meghajoltam, de most már természetes, de hogy közte mi történt, azt nem tudom. Én ennek az egésznek nagyon megélem a szakralitását, azt hiszem. Imádom a szertartásokat, és amikor vége lett [az egyik szertartásnak], akkor egy hiányérzetem volt, hogy én legszívesebben egész nap csak hajlonganék, tehát hogy semmi mást nem csinálnék, csak minden előtt meghajolnék, mert annyira megtisztító volt. De minden, a zendónak ez az elrendezése is, hogy leülünk, hogy ott csönd van, a harang, az egy jó dolog." (Panni)

$\mathrm{Az}$ alábbi két interjúból pedig szépen megmutatkozik a halállal kapcsolatos szertartások szerepe, amelyek nagyon megindítóak tudnak lenni. A halál témája 
nemcsak a szertartásokon kerül elő ${ }^{11}$ - a mulandóságon való meditálás a buddhizmus gyakorlásában egyébként is nagyon fontos szerepet tölt be.

„Nagyon szeretem őket, A föld három érintését imádom, az annyira oldja a határokat, nagyon közel áll hozzám. Az Ősöket is szeretem, az első pár évben nagyon ütős volt, meg amikor a nagymamám meghalt, az borzasztóan erős volt, nagyon szép. Szóval teljesen attól függ, hogy az ember milyen lelkiállapotban van, mi érinti meg. Tudom a szépségét, hogy az elmúlt évek alatt engem is többször megérintett. Fontos, hogy legyenek a szertartások." (Nikolett)

„Az anyám hamvaival megcsináltam ugyanazt a szertartást, amit a szanghában megcsináltunk azzal, aki ott meghalt, és utána kimentünk valami szigetcsúcsra, csónak, gyertyák, gyönyörü volt, őneki ez volt a kívánsága." (László)

A szertartások szépségét többen is hangsúlyozták, de az alábbi (egyébként magát kifejezetten nem vallásosnak tartó, a buddhizmust sem vallásként megélő) megkérdezett számára a menedékvétel elengedhetetlenül fontos a gyakorláshoz, ami jól jelzi a mélyebb elkötelezettségét.

„Úgy érzem, hogy ez nekem sok más szangha-tagnál fontosabb. Mert úgy érzem, hogy tradíció nélkül nem lehet. Nem lehet úgy betérni, hogy az ember ne vegyen menedéket (...), ami egy rituálé, és kifejezetten semmilyen gyakorlati jelentősége nincs, csak tradíció. Vagyis nem teljesen, mert a szangha, úgy gondolom, egy közösség, abban több tizenvalahány ember él, akik összeülnek. És attól lesz szangha az összes gyakorló ember, és attól lesz szangha a kis szangha, hogy vannak benne ilyen nehezen megfogalmazható összetartó erők. És abban, hogy én felvételt nyertem a szanghába, abban benne volt minden szangha-tagnak a személyes igenje. Ez nagyon fontos egy embernek, aki gyakorolni akar onnantól kezdve élete végéig." (Zsolt)

Összességében elmondható, hogy az elvonulások szertartásait a résztvevők szeretik, függetlenül attól, hogy mennyire élik meg a szakralitásukat. A megélés milyensége függ az adott személy korábbi tapasztalataitól, a személyiségétől és pillanatnyi lelkiállapotától, valamint az adott szertartástól is, és évről évre változhat. A résztvevők jellemzően megfelelőnek tartják a szertartások mennyiségét és hosszát, legfeljebb a nem annyira kedvelt szertartásokon esetenként nem vesznek részt.

91 „Anyám haldoklásánál azon kaptam magam, hogy a halálról meg a halálhoz közeledésről hallgattam előadásokat, olvastam buddhista szövegeket. Amikor anyámat készületlenül érte ez a dolog, egyből arra gondoltam, hogy kéne neki segíteni, hogy felkészüljön, meg hogy velem ez nem fordulhat elő, hogy egy ilyen fontos dologra nem készülök fel. Amióta ő beteg lett, én a saját halálomra készülök, ez felnyitotta a szememet." (Boglárka)

„Idősebb emberek, különösen a buddhisták már erősen gyúrnak a halálra, ne legyen annyira izé, amikor jön." (Ádám) 


\subsection{Mit jelentenek az elvonulások a résztvevők számára?}

A szertartások mellett arra is rákérdeztem, hogy mit jelentenek az elvonulások a résztvevők számára, akik két csoportra oszthatók: akik eddig csak a Szelíd Mosoly elvonulásain voltak (főleg a magyarországi elvonulásokon, esetleg a Szelíd Mosoly hollandiai és németországi elvonulásain), és akik járnak más elvonulásokra (illetve elvonulás jellegú táborokba vagy programokra) is. Ilyen pl. a vipasszana meditációs elvonulás, a csendtábor, a jógatábor, más buddhista közösség elvonulása, különféle külföldi (amerikai, angliai, portugál, távol-keleti stb.) elvonulások, meditációs programok, El Camino. Bár az egyes elvonulások formájában vannak jelentős különbségek, a céljaik hasonlóak: a kiszakadás a mindennapi élet forgatagából, a befelé figyelés, az elme lecsendesítése, letisztulás, a koncentrációs készség és az empátia erősítése, az önfejlesztés, az érzelmek erőteljesebb megélése, a közösségi élmény, a „jelenben levés”. Az elvonulásra indulók motivációi különbözőek: vannak a kíváncsiak; mások valamilyen nehéz élethelyzetben keresnek olyan dolgot, ami segít a megküzdésben; vannak, akik alapvetően rekreációs lehetőségként tekintenek rá; és vannak, akiknek elsősorban a közösség a fontos. Jellemző, hogy a közösség egy tagja ajánlja valakinek a Szelíd Mosoly elvonulását.

Megkérdeztem a résztvevőket, mit ad nekik az elvonulás, ha a megérkezést mint bemeneti pontot, a távozást pedig mint kimeneti pontot tekintjük. Rákérdeztem arra is, hogy mennyi ideig tartott ki a pozitív hatás a hazatérés után. Erre különböző válaszokat kaptam néhány naptól egy évig terjedő intervallumban. Az alábbiakban felsorolásjelleggel szerepelnek a személyes érzéseket megvilágító interjúrészletek.

„Nagy lökést [ad], megerôsíti az identitásomat. Azt nem érzem, hogy lettem volna olyan elvonuláson, ami mérföldkő lett volna, de azt érzem, hogy letisztulva jövök ki, de az nem marad úgy sajnos. Inkább az első pár elvonulásról éreztem azt, hogy vittem haza tartósabb dolgokat, most már inkább csak azt érzem, hogy más a bemenet, mint a kimenet, de hogy mennyire tartós, azt nem tudom." (Péter)

„Az első két nap szörnyű volt, de aztán utána a csend, az egész légkör, amiket Jan mondott, nagyon átmosott, ezért idén is elmentem, de idén nem éreztem olyan jól magam. Az első két nap szörnyű volt, mert számomra idegen volt, csendben kellett lenni, és amíg az agyamat le nem tudtam választani, amíg nem 
tudtam átélni, hogy benne van az agyam a mosásban, addig nem éreztem jól magam. [Az elvonulás után] a nyugi kitartott egy ideig, fóleg a nyugi, de hát minden, ami kiránt a hétköznapokból, hoz be új gondolatokat, az kitart egy darabig." (Erzsébet)

„Csendet, jelenben levést, boldogságot. Hónapokig kitartott utánuk az érzés, és szerintem teljesen ugyanarra a szintre soha nem szivárognak vissza a hétköznapok, szép lassan csökken a hullám, építkezik felfelé." (Balázs)

„Mindegyik más, Angliában a meditáció volt a legjobb, nemcsak az, hogy shrine room hangulata volt, hanem hogy jutott mindenkinek négy párna, mert én nem tudok lótuszban ülni. Meg számít az a kellék, hogy volt egy ilyen pokrócszerű nagy köpeny, amitől azonnal volt egy olyan érzésem, hogy ahogy ülök a földön, egy vagyok a földdel, bele vagyok nőve a földbe, ami egy fantasztikus dolog volt, segítette az összpontosítást. Ezek mindkét angliai elvonulásomon megvoltak, és mindig fantasztikusakat meditáltam. Itt Magyarországon meg ezek a kellékek hiányoztak." (Ádám)

„Az elvonulásokon a határok érzékenyebbé válnak, és kijön egy-egy ego, kijön mindenkinek a maga kis játszmája, és ez nem mindig egyszerű egy elvonuláson. Ez az, ami könnyebbé tesz egy néma elvonulást, mert nem jönnek ki a súrlódások. (...) Amikor eljövök, nagyon boldog vagyok, egy harmónia meg boldogság van." (Nikolett)

„Az elvonulás mindig mást ad, pl. az [egy hollandiai elvonulás] akkor azt adta, hogy nem vagyok egyedül, ott a közösségi élmény volt nagyon erős. Aztán utána azt, hogy nem kell megőrülnöm, hogy most akkor dió vagy mogyoró vagy mi. Ez már nem a személyes szintű, hogy akkor szimpatikus, nem szimpatikus valami, hanem az egész érdekében hozott döntés. (...) Most megerősítések voltak, bennem lévő gondolatok erösödtek meg, segített letisztulni, és nem eltévelyegni a sok fogalom közt." (Eszter)

„Elvonulás után egy-két hónapig elég jó, van egy nagy svungja, és bennem nagyon sokszor van, naponta többször, hogy beugrik egy tanítás. De minél jobban távolodunk időben az elvonulástól, annál nehezebb. Mindig azt szoktam mondani, hogy nekem az egy évre elég, persze ez innen indul [mutatja magasan], és majdnem nulla, mire a következő elvonulás jön. Bennem sokszor bennem van, hogy én örökre ott akarok élni a szanghában. Az elvonuláson sokkal összeszedettebb vagyok, mint máskor." (Panni)

„Nagyon sokat adott a máriahalmi elvonulás, a levélégetés: írsz, akinek akarsz. Nem bírtam a levelet megírni, úgy zokogtam, az égetéssel valóban sikerült megszabadulnom, jónak tartottam. Annyi mindent adott nekem, a gyakorlatok, a föld érintése, amit úgy csinálgattam. Mert tök jó ebben az egész történetben, hogy nem kötelező, ajánlott, és akkor rájössz az ízére, hogy hmm, ez így jó, működik. Lecsendesülést adott, azt észrevettem, hogy amikor jöttem el, nekem az út mentén még a virágok meg a fü színe is más volt. A hangok is mások voltak, az egész érzékelésem megváltozott. Olyan ruganyos volt az út, direkt lassan jöttem, odafelé még azt éreztem, hogy mikor érek már oda, a sebesség, a 
feszültség bennem... (...) Egyvalamit hiányolok ebben a szangha-történetben, $a$ bennünk lévő düh, méreg és sértettség elfojtása meg kellene hogy nyilvánuljon valamiféle agresszivitásban, konkrétan arra gondolok, hogy nem ártana, ha volnának olyan bokszzsákok vagy valami, hogy ott vagyunk csöndben, amiben kijön a feszültség." (László)

„Testi szinten a nyugalom, az kitartott jó pár napig utána. Akkor az, hogy mégiscsak csatlakoztam egy ilyen vallási közösséghez, az ilyen nagyon jó mély megelégedettség volt, ilyen hazatérés. Spirituálisan nagyon sokat adott, az leírhatatlan, tényleg számított, a szangha ereje meg a beavatás maga, az tényleg számít." (Gábor)

$\mathrm{Az}$ alábbi interjúrészletben is hangsúlyosan megjelenik a csend és a szangha jelentősége, valamint az értekezésben tárgyalt más témakörök is, így a tudományos kapcsolódás, a közösség általi megerősítés a gyakorlásban, az, hogy szimpatikusak a közösség tagjai (lásd a közösséget tárgyaló fejezetnél).

„Nagyon sokat kaptam a szanghától. Az emberek is a helyükre kerültek, itt nem voltak ilyen félörült istenkeresők, akik más helyeken igen, akikkel viszont én nem akarok beszélgetni. És hogy az éber figyelem, a mindfulness része mire képes, arról sokat olvastam, érdekelt a neurobiológia, az agyi plaszticitás kérdései, hogy ezek a technikák mire képesek. És hát varázslatos ezt a dolgot megélni és megérezni, tényleg már az első nap után, már simán attól, hogy kénytelen vagyok ott nemes csendben lenni, meditáció nélkül is éber figyelem állapotában szemlélni a környezetemet. Ha még ezt az ember komolyan is veszi, és megpróbálja úgy csinálni, ahogy tanítják, ez a kettő együtt zseniális dolog. Úgy gondolom, hogy már az első estétôl kezdve éreztem ennek a pozitív hatását, és ez sokáig meg is maradt. Ez adta nekem azt a lendületet, hogy később gyakoroljak minden reggel és este." (Zsolt)

A megkérdezettek jellemzően sokat gondolkodtak ennél a kérdésnél, de végül nagyon hasonló válaszokat adtak. Az idézetekből jól látszik, hogy fontos a testi, érzelmi, spirituális és intellektuális dimenzió is. Különösen jelentős szerepe van a csendnek, ez elengedhetetlen ahhoz, hogy az elvonulás a résztvevő számára „eredményes” legyen. Egyértelműen megmutatkozik az elvonulás rekreációs funkciója: a feltöltődés, átmosódás, megkönnyebbülés, a problémák elengedése és a boldogság növelése. 


\section{A kommunikáció ágensei}

Ebben a fejezetben kétféle ágens jelenik meg: individuális személyes ágens és kollektív humán ágens. Emellett beszélhetnénk a transzcendens ágensről is, azonban a dolgozat kizárólag a jelentésadó ágens nézőpontjából vizsgálja tárgyát. Az individuális személyes ágensek a közösség tagjai (itt bizonyos értelemben külön kezelhető a „mag” és a „holdudvar”), a tanító és a tolmács, akik különböző felkészültségekkel rendelkeznek. A kollektív humán ágens a közösség egésze, és az interjúkból látszik majd, hogy eltérnek a vélemények abban a tekintetben, mennyire működik a közösség kollektív ágensként (kifejezetten nem a kollektív szuperhumán ágens értelmében).

\subsection{A mag és a holdudvar}

A közösségbe való belépés feltétele az egy nyári elvonuláson való részvétel. Emiatt nehéz meghatározni, hogy pontosan kik tartoznak a közösségbe - aki részt vett ilyen elvonuláson, felkerül a szangha levelezőlistájára, ahol meghívást kap a különféle programokra. A közösségben való részvétel szintje ennek megfelelően változatos. Van egy ún. mag, akik szervezik a programokat, döntenek a közösséget érintő kérdésekről, és bizonyos rendszerességgel részt vesznek a minden hónap utolsó vasárnapján tartott találkozókon. Van egy olyan szintén stabil csoport, akik ugyan elfoglaltságaik vagy más ok miatt nem vagy ritkán vesznek részt ezeken a találkozókon, de az elvonulásokon lehetőség szerint jelen vannak, őket nevezhetjük a holdudvarnak. Vannak ezenkívül olyanok is, akik részt vettek egy-két vagy néhány elvonuláson, de aztán „továbbálltak”, esetleg egy-egy előadáson megjelennek.

A szangha taglétszámának megadása nemcsak emiatt nehézkes, hanem az önmeghatározás változatossága és bizonytalansága miatt is. Az interjúk során mindig rákérdeztem arra, hogy az illető a közösség tagjának tekinti-e magát, és ha igen, hogyan jellemezné a részvétele szintjét. Erre nagyon sokféle választ kaptam: nem; igen; nem tudja; kizökkent, de szeretne visszatérni; perifériális; visszalépett kicsit stb. Ez is jelzi azt, hogy a közösség meglehetősen rugalmasan kezeli a tagságot, ami 
egyrészt valószínűleg rontja a kohéziót (van, aki nem is tekinti igazán „közösségi ágensnek" a szanghát), másrészt könnyebbé teszi a bekapcsolódást. E tekintetben egyértelműen változik a szangha: korábban a már említett pszichológusi csoportból állt, de az utóbbi években egyre több új arc tűnik fel a programokon.

A csoport szociológiai összetételét tekintve ez a változás azt is jelenti, hogy a szangha fiatalodik. Az általam látogatott elvonulásokon a legfiatalabb résztvevő középiskolás volt, a legidősebb 70 éves kor feletti. Több a nő, mint a férfi, és igen magas a felsőfokú végzettségűek aránya - akikkel beszélgettem, gyakorlatilag mind vagy felsőfokú végzettségűek voltak, vagy valamilyen alternatív (államilag elismert vagy azon kívüli) végzettséget szereztek középiskolai tanulmányaik után. Az alapítás körülményeinek megfelelően kiemelkedő a pszichológusok, terapeuták és más segítő foglalkozásúak aránya, a többiek jellemzően különféle humán- vagy reálértelmiségi területeken dolgoznak, illetve dolgoztak (tanár, szociológus, informatikus stb.). Összességében a közeg nagyon kulturált, ami nem jelenti azt, hogy ne adódnának konfliktusok vagy nézeteltérések, illetve „pufogások”, de ezek kezelése kulturált módon történik.

A mélyinterjúk esetében igyekeztem bizonyos szórást alkalmazni, és megkérdezni különböző korosztályú, eltérő elkötelezettségű, a magba és a holdudvarba tartozó nőket és férfiakat is. A minta nem reprezentatív, de ettől függetlenül is jól kirajzolódnak az elméleti részekben említett jellegzetességek és attitűdök. A terepmunkám alapján úgy vélem, hogy a minta növelése nem módosítaná jelentősen a levont következtetéseket, bár kétségkívül újabb érdekes életutakat ismerhetnénk meg, és értékes meglátásokat nyerhetnénk az esetleges további interjúkból. Az elvonulásokon tett megfigyeléseim arra utalnak, hogy ezek az elkötelezettség és a buddhista „műveltség” még szélesebb spektrumát tárnák fel, beleértve az itt bemutatottaknál mélyebb elkötelezettségeket és magasabb szintű ismereteket is.

Összesen 15 interjút készítettem: egyet a tolmáccsal, a többit a résztvevőkkel. A legfiatalabb megkérdezett 30 éves férfi, a legidősebb 65 éves nő volt. ${ }^{92} 13$-an állami felsőfokú végzettséggel, ketten az állami iskolarendszeren kívüli végzettséggel rendelkeznek, ennek megfelelően segítő és szellemi munkát végeznek,

${ }^{92}$ A megkérdezett nők életkora: 31, 38, 38, 38, 50, 58, 59 és 65 év A megkérdezett férfiak életkora: 30, 38, 38, 44, 53, 57 és 64 év 
többen felelős pozícióban. Egy megkérdezett az agglomerációban lakik, a többiek Budapesten élnek. Többen éltek vagy töltöttek hosszabb-rövidebb időt külföldön. Mindannyian nyitott, érdeklődő emberek.

A közösségről általánosságban elmondható, hogy az átlagosnál érzékenyebb, toleránsabb, békésebb emberek alkotják. Amint említettem, abban megoszlanak a vélemények, hogy a közösség mennyire funkcionál kollektív ágensként, de ezek a véleménybeli eltérések összefüggenek egyrészt a szerepvállalás és elkötelezettség szintjével, másrészt a közösséggel kapcsolatos elvárásokkal is. A pozitív oldalon a megkérdezettek a következőket emelték ki: a tagok intelligensek, jókat lehet velük beszélgetni; megvan a közösség és az együttlét érzése; a tagok szimpatikusak és hasonlóan gondolkodnak; a közösség támogatást és erőt ad; megtáplál és megtart; nincsen fanatizmus és nincs konfliktus abból, ha valaki más közösségbe is jár; a közösség segíti a gyakorlást.

Amikor rákérdeztem arra, mi hiányzik a közösségből, akkor az alábbiak merültek fel: jó lenne többet tudni egymásról; kicsit kifáradt, nem látszanak eléggé a megújulás jelei; túl nagy és túl hierarchikus; jó lenne, ha kisebb csoportokra szegmentálódna; unalmas a programok ismétlődése; kevés a közös gyakorlás, rendszeresebbnek kéne lennie; nagyobb intimitásra lenne szükség. Azt többen is fontosnak tartották megjegyezni, hogy nem gondolják, hogy egyetlen közösség ki tudná elégíteni minden igényüket, így nem is várják el tőle. Mindezek alapján úgy gondolom, hogy a közösség működik közösségként, azonban egy lazább szerveződéssel, aminek megvannak az előnyei (mint a könnyű bekapcsolódás) és a hátrányai (mint a gyenge kohézió) is.

\subsection{A tanító}

A Szelíd Mosoly szangha esetében a tanító szellemi vezető, a szervezést és egyéb ügyek intézését a mag tagjai végzik. Az elvonulásokat többnyire Jan Boswijk vezeti, de Hilly Bol is részt vett ebben már több alkalommal is, valamint legutóbb Cuong Lu vezette az elvonulást. A terepmunka során kérdés volt számomra, hogy mennyire a tanító köré szerveződik a szangha, és mennyire életképes „önállóan”, ezért minden interjúalanyomat megkérdeztem, mit gondol erről. Megkérdeztem azt is, mennyire fontos nekik, hogy a tanító karizmatikus legyen (a válaszokból az derült ki, hogy nem 
igazán fontos), és milyen más jellemzőket emelnének ki általában egy tanítónál, illetve mik a Szelíd Mosoly tanítóinak erősségei. Mivel a legtöbb elvonulást Jan Boswijk vezette, főleg az ő személye került szóba, de Hilly Bolról és Cuong Luról is beszéltünk néhány megkérdezettel.

Az elméleti fejtegetéseknek megfelelően a fő kérdések, amelyeket érdemes tárgyalni ebben a fejezetben, az alábbiak: mennyire épül a közösség a tanító személye köré? Többletet jelent-e a pszichológiai szemlélet, vagy ellenkezőleg, levon a buddhista tanítás értékéből? Mennyiben tud a tanítás újat nyújtani azok számára, akik évről évre részt vesznek a programokon? Mitől lesz hiteles a tanító?

Mint korábban már említettem, Jan Boswijk buddhista tanító civilben pszichológus, pszichoterapeuta, és ebben a minőségében érkezett először Magyarországra. A közösség alapító tagjai pszichológusok, és egyébként Boswijk hollandiai szanghája is segítő foglalkozásúakból áll. Ez meghatározza a tanítások szellemiségét - hogy pontosan mennyire, azt nehéz definiálni, mivel a pszichológiai és a buddhista elemek szervesen jelennek meg a tanításokban. Az egyik megkérdezett ezt így fogalmazta meg:

„Nekem fontos a pszichológia, fontos az, hogy a Jan tudja, hogy ő ki, hogy amit tanít, az az adott helyzetben mennyiben egy kogníció, mennyiben élményszintű, és hogy milyen módon történik az átadás. Szervesnek érzem a buddhizmust és a pszichológiát, az utolsó két elvonuláson az jutott eszembe, hogy ollóval szét nem választható. Tehát lehet pontosítani a buddhizmus oldaláról, meg tudnám pontosítani a pszichológia oldaláról, de minek, amikor ez így van rendben." (Márton)

Ugyanakkor van néhány olyan terület, amelyek esetében viszonylag könnyen azonosíthatók a pszichológiai elemek, illetve szellemiség: ilyenek a Boswijk pszichológiai praxisából hozott példák, bizonyos buddhista elképzelések (pl. az elme [manasz] működése) magyarázata, a (fenti idézetben is említett) átadás minősége, felépítettsége, valamint a saját fejlődési út bemutatása.

„Fantasztikus benne, hogy olyan szinten van, hogy már generál magának dolgokat, amiken keresztülmegy, és megoldja a maga számára, és ezt meg is osztja. Jan tanításai nagyon tetszenek, nincs hiányérzetem. Nem érzem azt, hogy ismételné magát, ez egy tanításon belül is érezhető lenne. Jannál nagyon fel vannak építve ezek a dolgok, elindul valahonnan és eljut valahova, nagyon végig van gondolva, magas szintü, érződik rajta, hogy PhD-szintű ember. Másokkal összehasonlítva kiemelkedő volt, egy ilyen volt, a tibeti szerzetes.” (Boglárka) 
A résztvevők több esetben is kiemelték, hogy szeretik, amikor Boswijk megosztja a saját fejlődési útját, a kételyeit, mivel ettől emberi, és így könnyebb azonosulni a tanítással. ${ }^{93}$ Ezzel kapcsolatban egyetlen félig-meddig negatív megjegyzés érkezett csak a 2015. nyári elvonulással kapcsolatban:

„[A kételyek kifejezése] az utóbbi időben egy picit zavaró volt, az utolsó elvonuláson volt egy pont, amikor azt éreztem, hogy ez nekem most már sok, ez most már róla szól. Hogy oké, ezek az ő kételyei, nagyon szimpi, hogy felvállalja, meg ki tudja mondani, meg tud vele dolgozni, sőt, be is tudja építeni abba, ahogy a tudást átadja. Hogy nem érzékelteti, hogy fél, de mivel ilyen erős a kétely, akkor az valószínúleg nem átadható. Tehát akkor az egy beszélgetés már, nem tanítás. Tehát rá figyeltem, meg arra, hogy milyen lehet neki, és nem arra, hogy hogyan élem meg én." (Márton)

Van, akit nem érdekel, személy szerint milyen a tanító, ha a tanítás utat talál hozzá. Másnak fontos a jó tanító, mert hosszabb távon csak így működőképes a dolog rövid távon egy alapvetően rossz tanító is adhat jó tanítás, de hosszú távon nem lenne kíváncsi az ilyen ember tanítására. A tanító személyiségével kapcsolatban még

\footnotetext{
93 „Az ilyen apafigurákkal mindig van egy távolságtartás bennem, tehát nekem eszembe nem jutna, hogy leüljek mellé, és megkérdezzek tőle valamit. Ennek nyilván nyelvi gátjai is vannak, hogy mennyire tudom magam angolul kifejezni. De nagyon érdekes, hogy annak ellenére, hogy személyesen nem beszéltem a Jannal, elköszönésekkor nagyon sokszor mondott nekem egy-egy mondatot, amiből azt éreztem, hogy ô engem lát. (...) Ez egy másik szintű kapcsolat, amikor nem ezen a hétköznapi szinten vagy kapcsolatban, hanem azt érzed, hogy figyel rád, tehát hogy én hagyok benne valami nyomot. És én nagyon szeretem nyilván alkatomból fakadóan, amikor ezeket az ôszinte sztorijait elmondja, hogy amikor ő először volt Indiában vagy nem tudom hol, akkor ő ott pár nap után elkezdte osztani az észt jó holland módjára, hogy hogy kéne megszervezni az életet, és ebben tökre magamra ismertem, és azt gondoltam ezekből a sztorikból, hogy én jó helyen vagyok. Attól hiteles, hogy bele tudja szôni a tanításokba, hogy ő hogy küzdött, hogy bemutatja azokat a lépcsôfokokat, ahogy ő megértett ebböl az egész rendszerből dolgokat. Ettôl lesz emberi és ettôl lesz hiteles, meg attól is, hogy azt mondja, hogy bevállalja az öregedését, meg minden ilyesmit. Egyetlenegyszer haragudtam rá, amikor nőügyekben nem akart állást foglalni. Hogy mi van, amikor egy buddhista szerelmes, és olyanba szerelmes, akibe nem lehetne." (Judit)
} 
az merült fel igényként, hogy legyen benne együttérzés, szeretet; ${ }^{94}$ adjon szabadságot, de azért fogódzókat is; ${ }^{95}$ legyen hiteles ${ }^{96}$.

A hitelesség összetett kérdés, egy buddhista tanító esetében különösen fontos a személyiség, a kisugárzás, az átadások minősége. Ez a fentebbi idézetekből is kiderült, és a következő interjúrészlet nagyon jól (és a saját benyomásaimmal megegyezően) írja le ezt.

„[Idővel] eljutottam addig a hihetetlen magaslatig, hogy rájöjjek arra, hogy az olvasgatás nagyon-nagyon kevés, nagyon messze van a gyakorlástól, és rájöttem arra, hogy a gyakorlásnak van igazából jelentősége. Ez vitt arra, hogy szanghákat keressek, de vagy a szanghákban megfogalmazott kérdések, vagy a tradíció vonulata mindenhol megálljt parancsolt, amikor egyszer egy Tan Kapuja Buddhista Főiskolás előadásán Jannak úgy éreztem, hogy ennek az embernek nagyon erôs kommunikációs kisugárzása van. Ahogy ül a térben, és ennyire nyugodt körülötte minden, és minden elképzelhető érzelmi hullámzás mint valami tóba dobott kő, látom a hullámzást, aztán az egész elcsendesedik. Ez is nagyon fontos. Aztán a másik fontos dolog, hogy a válaszai vagy a föltett kérdései alapján úgy helyénvalónak gondoltam ezt a tradíciót." (Zsolt)

Hilly Bollal a közösségnek kevesebb tapasztalata van, de az ő elvonulásán részt vevők a „női energiáit” emelték ki, és különösen a teljes relaxáció alatti gyönyörű hárfajátékát és éneklését.

„Hilly hátborzongató volt, hogy tudtuk, hogy a haldoklóknak is ezt szokta csinálni.” (Nikolett)

Cuong Lu tanítása a résztvevőknek általánosságban nagyon tetszett, de a helyszínen többen említették, hogy nem volt számukra teljesen érthető a tanítás. Ezen a kétnapos elvonuláson és az elvonulás előtti napon tartott előadáson a boldogság

\footnotetext{
94 „Olyan mestert szeretnék [Magyarországon], akitől tudnék tanulni, akiből sugárzik a compassion, a kedvesség. Jan pl. ilyen, amit mondott, ahogy mondta, a humánus attitüd, az nagyon tetszett. Ha tartana rendszeresen tanításokat, biztos eljárnék hozzá." (Ádám)

95 „Ez az abszolút elengedettség a Jannál teljesen megvan, ugyanakkor mégis vannak kis határok, ilyen szeretet-rendszer, amit Jan felállít. Van rendszer, vannak fogódzók, de ugyanakkor nagy belső szabadság van, lehet befele figyelni, de közben teljes elengedés van, meg lágyság. Jan nekem ott válik érdekessé, amikor kilép a rendszerből, egyébként ugyanazokat hallottam már nagyon sokszor. Amit a Jannál nagyon szeretek, az pont az, amit nem szoktak reklámozni, a total relaxation, az valami egészen különleges, ahogy ő csinálja." (Nikolett)

96 „[Nekem az számít], hogy az, amit hallok, és itt akár Jan tanítására gondolok, attól én összerendezettebb leszek-e, az tápláló-e nekem, vagy nem, segit-e élni, vagy nem. Jan személye hiteles volt számomra, láttam, hogy mint terapeuta mit csinál." (Eszter)
} 
volt a téma: a szenvedés valódi természetének felismerése, békévé és örömmé alakítása a nem-tudat meditáció segítségével.

„Cuong a tanítás keretén belül mozgott, ilyen szempontból, így felületesen mintha autentikusabb lett volna, de hát ki az autentikusabb, az öreg paraszt bácsi Zalában, aki ott él, és úgy csinálja, vagy az, aki két generáció után visszaköltözik Pestről, és felújítja a szülői házat, és úgy csinálja tovább. Mind a kettő [autentikus], csak más. Nagyon érthető volt Cuong, az én belső spirituális fejlödésemmel párhuzamosan zajlott, ott az történt velem, azt csináltam, amit mondott, de minden egyes pontját, nagyon jó volt. A visszajelző körökben többen felvetették, hogy »nem értettem«, »ez még túl magas nekem«. Én kristálytisztán megértettem, nagyon szép volt a Cuong. Az, amit mondott, hogy ott a boldogság, az állandóan veled van, azt nem lehet megérteni aggyal, azt át kell élni testtel is, meg szívvel is." (Gábor)

Egy másik résztvevő nagyon jól megvilágította az ázsiai és az európai ${ }^{97}$ tanító eltérő és egymást kiegészítő szemléletmódját.

„[Cuong] nagyon-nagyon mély volt. Jan mondta azt, hogy amikor először hallotta Thich Nhat Hanh-t, akkor nagyjából hasonló lehetett, amit megélt. Merthogy azt lehetett megélni, hogy iszonyú triviális, banális, és túl egyszerüen fogalmaz meg dolgokat. Három egyszerü mondatból állt az egész Dharmatanítás, de hihetetlenül bonyolult szimbolikai [tartalma volt], és erôs alapja. És egy nagyon nagy mélység húzódik mögötte, főleg amikor a visszakérdezésekre ösztönösen tudott válaszolni. Jan nagyon európaian tudja elmondani a dolgokat, ami nagyon jó, és ezért is kötöttem ki a szanghánál, de ő [Cuong] meg ki tudta egészíteni azt, amit [Jan] szokott mondani. Nagyon autentikusnak éreztem, zsigerből, majdhogynem testi szinten, igazi dó-átadása volt Cuongnak." (Zsolt)

Összességében elmondható, hogy a közösség számára fontos a tanító személye, és nagyon elégedettek Jan Boswijkkal és a meghívott többi tanítóval. Azok, akik régóta részt vesznek az elvonulásokon, a tanításokat esetenként ismétlésnek élik meg (de többen jelezték, hogy minden évben újabb és újabb rétegeit fedezik fel) - mivel mindig vannak új résztvevők, a tanító egyik legnehezebb feladata éppen az ismétlések kerülése.

97 Több megkérdezett is említette, hogy érzékelik a tanítónál a holland kultúra hatását is, pl.: „A kulturális torzítás is benne van. Van egy ilyen kelet-nyugati, aztán van a holland, ami egy elég sajátságos történet a maga kultúrájával, történetével és szerepével Európában, és a gazdaságilag elfoglalt helyével. Területhódítások, időjárás, a folyamatos gyötrődés. Abszolút érzem Janban ezt a kultúrát." (László) 


\subsection{A tolmács}

$\mathrm{Az}$ elvonulásokon való tolmácsolás speciális, jelentős érzékenységet igénylő, fárasztó feladat. Mentálisan is kimerítő, mivel a tolmácsnak mindennap reggel 6 órától legalább este fél 10-ig, de gyakran tovább is rendelkezésre kell állnia. Mindazonáltal nem az idődimenzió teszi igazán nehézzé ezt a munkát, és még csak nem is a sajátos terület (a buddhista terminológia stb.), hiszen a tolmácsolás eleve olyan szakma, ahol nagyfokú rugalmasságra és minden újabb megbízás előtt bizonyos felkészülésre van szükség. A feladat specialitását egyrészt a színtér sajátossága adja, másrészt pedig a kommunikációban részt vevő ágensek hétköznapitól eltérő lelki/tudati állapota, ami fokozott körültekintést igényel a tolmács részéről. $\mathrm{Az}$ alábbiakban ezt a speciális szituációt mutatom be a tolmáccsal és az elvonulás résztvevőivel készült interjúk és a terepmunkás megfigyeléseim alapján. Azt elöljáróban elmondhatom, hogy a Szelíd Mosoly Buddhista Szanghának sikerült egy olyan tolmácsot találnia és vele hosszú távú együttműködést kialakítania, aki szakmailag és emberileg is mindenben megfelel a közösség támasztotta igényeknek. ${ }^{98} \mathrm{Az}$ egész kutatásomban ez volt az a pont, amelyben a közösség szinte minden olyan tagjának véleménye egybeesett, akivel akár az interjúk során, akár az elvonulásokon beszéltem. Gyakorlott fordítóként pedig magam is hasonló véleményen vagyok.

Az elvonulásokon a tolmács feladata nem szorítkozik az előadások (Dharmatanítások) fordítására, hanem egyrészt ő tolmácsolja a szertartásokat, meditációkat, relaxációt is, másrészt az évek során úgy alakult, hogy általános kommunikációs „üzenőfalként” is működik. Így például bár az étkezések második (nem csendes) felében bárkinek lenne módja szót kérni, ha az egész közösséget érintő bejelentést kívánna tenni, illetve kérni szeretne valamit, ezeket a bejelentéseket és kéréseket is inkább a tolmácsnak mondják el, aki közvetíti őket a csoport felé. Szakmailag

\footnotetext{
${ }^{98}$ A közösség tolmácsa végzettségét tekintve tolmács-szakfordító, aki a „fiatal felnőttkori normatív krízise" időszakában lassan elkezdte magát átképezni, ami azt jelentette, hogy a fordítást és tolmácsolást szabadúszóként végezte, közben pedig 6 évig családterápiát tanult. A családterápiás képzés elvégzése után pszichodinamikus szemléletű mozgásterápiás képzésben vett rész. A közösségben kb. 9 éve tolmácsol - ez akkor kezdődött, amikorra a személyes és szakmai érdeklődése is a pszichológia és a lélek felé fordult. A tolmácsolás-fordítás összekapcsolódott ezzel: pszichológiai témájú könyveket fordított, és zömében ilyen témákban is tolmácsolt, különféle pszichológiai és kapcsolódó képzéseken és iskolákban, nyári egyetemeken.
} 
természetesen nem ez okoz nehézséget, itt csak azt kell megjegyezni, hogy ez a feladat elvileg nem tartozna a tolmács munkájához, csak ahogy ő fogalmazott, az évek során „ránőtt”.

Ami a tulajdonképpeni tolmácsmunkát illeti, azt az alábbi - különféle készségeket és tudást igénylő - részekre lehet felosztani. Vannak egyrészt a Dharma-tanítások, ezek a leginkább klasszikus értelemben vett előadások, ennek megfelelően ez jelenti a leghagyományosabb tolmácsfeladatot is. Ilyenkor a tolmács jellemzően csak a szokásos munkaköri nehézségekkel szembesül, amilyen a megfelelő terminológia és stílus megtalálása, illetve az olyan jellegű problémák, mint például ha nem megfelelő a hangosítás, és a tanító elfordulva beszél, nehezebben érti a beszédét. Ezenkívül zavaró lehet számára az, ha valaki kérdezésnél nem tartja be a megszokott csatornákat - tehát azt, hogy a tolmács alapértelmezetten a hallgatóság felé magyarra, a tanító felé pedig angolra fordít -, és angolul tesz fel kérdést. Azonban az évek alatt az ezzel kapcsolatos bosszankodása elmúlt, és csak azért szokott szólni, ha ez túl gyorsan történik: „ha hirtelen összekeverednek a csatornák, előfordul, hogy lefordítom magyarul Jannak".

Ennél jóval nagyobb kihívásokat tartogat a szertartások, a meditációk és a relaxáció tolmácsolása. A szertartások szakrális természete és emelkedettsége extra stresszt jelent, és különösen igaz ez a menedékvételi szertartásra. A tolmács tisztában van az emelkedettséggel és azzal, hogy a szertartás résztvevőinek élményét befolyásolja a fordítása:

„Már úgy csináljuk évek óta, hogy akár $A$ föld három érintését, akár az 5 éberfigyelem-gyakorlatot ő nem olvassa fel angolul, csak bejelenti, és én olvasom. Akkor az például nekem egy nagyon koncentratív állapot, hogy úgy tudjam olvasni, hogy az benneteket segítsen. Téged ez fog megérinteni az én hangomon, az én olvasásommal jutsz bele az állapotba, vagy jutsz kapcsolatba az érzéseiddel, éled át."

A szertartásoknál tehát nem csupán a szöveg egyszerű lefordítása a feladat, hanem hogy az az esemény szakrális jellegének figyelembevételével és tiszteletben tartásával történjen, ne akadjon meg a fordítás, valamint mindig a megfelelő, soron következő szöveg legyen felolvasva. Összességében az elvonulás utolsó két-három napja jelenti a legkeményebb feladatot a tolmács számára, ilyenkor nemcsak a szertartásokat kell tolmácsolni, hanem adott esetben lefordítani az ezeken felolvasott szövegeket, valamint a menedékvétel előtti estén lefordítani 
a jelentkezéseket, és segíteni a tanítónak a névadásokban. ${ }^{99}$ A névadás felelősségteljes feladat, hiszen a kapott névnek segítenie kell a gyakorlót a gyakorlásban, ezért sokszor a (három részből álló) név tartalmazza az illető „feladatát” is. Ilyenkor a felmerülő Dharma-neveknél a tolmács mesél a magyar szavak hangulatáról, jelentéseiről (például hogy a 'törődés' szóban benne van a 'törik' jelentés is). Itt tehát szemantikai-morfológiai kérdések is előkerülnek. Ezen a ponton különösen fontos a diszkréció.

A meditációk és a relaxáció tolmácsolásánál részben más jellegű nehézségek állnak elő. Az egyik az, hogy egy irányított meditációnál és a relaxációnál nagyon kevés idő van a fordításra, és hibázás esetén - a tanítással vagy a szertartással szemben - nem nagyon lehet visszamenni javítani. Mivel ezek módosult tudatállapotot idéznek elő, nagyon fontos a megfelelő intonáció és szóhasználat. A tolmácsnak például el kell lágyítania a hangját, de nem annyira, hogy „búgjon” (ez módszertani kérdés, mert a „búgás” már szuggesztiónak minősül). Van egy olyan begyakorolt hangtartománya, amelyből a helyzetnek megfelelően választ.

Az intonáció mellett fontos az átgondolt, körültekintő szóhasználat is. Az alábbi interjúrészlet érzékletesen mutatja be, mit ad hozzá a tolmácsi munka minőségéhez a szakterületi (jelen esetben pszichológiai) felkészültség.

„A szertartásokon sokszor füstöl az agyam, ott van ez a koncentráció, és ha a következő mondatban felfedezem, hogy rontottam, akkor gyorsan visszamegyek, elsimítom, és úgy megyek tovább. De az egy eléggé kiszolgáltatott helyzet, hogy te ott ülsz, vagy ott ül 50 ember, és meditál, és ő [a meditáció vezetője] mond valamit. Pláne azóta, hogy közben elmélyültem ebben a szakmában, és imaginációkkal, módosult tudatállapotokkal is

\footnotetext{
99 „Az elvonulások utolsó két napján jönnek a szertartások, és amit ma már - amikor te megérkeztél - látsz, ez tényleg sok év munkája. Mert ez úgy indult, hogy Jannak nem nagyon erőssége az előre tervezés, ő rutinból, intuícióból és ráhangolódottságból dolgozik, amit buddhista tanítóként nagyon megértek, de tolmácsként ez egy kicsit aggályos. És akkor én, a jó tolmács, aki kicsit edukálja is a klienst, mindig három héttel előtte bejelentkeztem, hogy én leszek a te tolmácsod, és kérlek, küldjél anyagot, hogy miből készüljek, de sose küldött. Aztán az első alkalom után, amikor már összeismerkedtünk, és érzékelte, hogy hogyan dolgozom, onnantól kezdve mindig sok éven keresztül elment ez az e-mail, amikor már egyáltalán nem volt olyan értelemben adekvát, hogy mindig mondta, hogy az lesz, ami szokott lenni. De ott álltam az első alkalommal, jöttek a szertartások, és Jan előre nem küldött semmit. Akkor lement az este fél tízes meditáció, és a maga édes módján mondta, hogy van itt egy-két dolog, amit akkor össze kéne rakni. Sose felejtem el, hogy az első elvonuláson hajnali háromkor álltam a tus alatt, amikorra nagyjából lefordítottam azt, ami másnap a szertartáson lesz, és próbáltam megtanulni, hogy Avalókitésvara bódhiszattva. Azt hiszem, hogy ezt még a halálos ágyamon is tudni fogom. Memóriafogasokkal dolgoztam, hogy avar-ló-kitessékel-varangy - így tanultam meg az Avalókitésvara bódhiszattvát."
} 
dolgozom, ezért tisztábban látom, hogy egy nagyon apró, nem jól megfogalmazott szó abban a befelé figyelő állapotban mennyire felhangosodhat, és akadást jelenthet. Tehát azt gondolom, hogy ha pusztán tolmács lennék, akkor talán nem érezném, hogy ennek bármi tétje is van, de most már van tapasztalatom arról, hogy egy testpásztázásnál például ha azt mondom, hogy érzékeled a koponyádat, az nem biztos, hogy egy jó szó, mert az emberek felének elkezdenek halálfejek jönni. A befelé figyelő, módosult tudatállapotban, imaginációban, mint amilyen a teljestest-relaxáció, érdemes ezzel vigyázni. És ilyen a meditáció is. Azt megfigyeltem, hogy ha lenne felvétel az elmúlt évekből, mindegyik évből a teljestest-relaxációról, akkor lehetne látni az én fejlődésemet is, mert már kicsit másképp fordítom. Méghozzá úgy, hogy korábban szorosabban úgy fordítottam, ahogy ő mondta, és amióta megtanultam a fókuszolást ${ }^{100}$, azóta kicsit fókuszosabban fordítom ezt. Tehát nem azt mondom, hogy érezd meg a fejedet, hmm, hmm, hanem azt, hogy megérezheted, odafigyelhetsz, ami egy megengedőbb szóhasználat, mert azt gondolom, hogy a relaxáció hangulatát ez jobban kifejezi. És erről van testi élményem is, hogy milyen azt hallgatni és milyen ezt hallgatni."

Ezzel kapcsolatban felmerül a kérdés, hogy a tolmácsnak mennyire kell hűen követnie a tolmácsolt személyt. Jelen esetben számolnia kell azzal, hogy a tolmácsolt személy nem az anyanyelvén beszél, ebből következően egyszerübb nyelvezetet használ, mint valószínűleg tenné azt, ha hollandul vezetne elvonulást. Egyszerű szavakkal és mondatszerkezetekkel dolgozik, amit a tolmács ötletesen, választékosan, olykor humorosan ad vissza. Jan Boswijk az első tolmácsolás után „megszondázta”, milyennek tartják a közösség tagjai a tolmácsolást, és mivel azt a visszajelzést kapta, hogy nagyon szeretik ${ }^{101}$, ez megerősítette a bizalmat a tolmács

\footnotetext{
${ }^{100} \mathrm{~A}$ fókusz módszer Eugene Gendlin osztrák származású pszichoterapeuta elmélete. Az ezen alapuló módszere, a fókuszolás a humanisztikus pszichológia irányzatához sorolható. Önismereti és személyiségfejlesztő módszer, befelé figyelés, önvizsgálat, önkorrekció, önfejlesztés, önsegítés. Alkalmazása során nő az intuíció, a belső empátia, így nő a külső empátia is, az aktív másikra figyelés képessége. A fókuszolás alapgondolata, hogy a testben, a zsigerekben van a lelki helyzetmegértés kulcsa, csak tudni kell figyelni a test belső jelzéseire. A figyelmet a megfelelő környezeti feltételek kialakításával és ellazulással teremthetjük meg. Az ellazulás önmagában is gyógyhatású.

Forrás: http://www.fokuszmodszer.hu/mi-a-fokuszolas/ (Utolsó letöltés: 2016. február 20.)

${ }^{101} \mathrm{Az}$ alábbiakban majdnem minden megkérdezett véleményét idézem, mert azt gondolom, nagyon pontos képet adnak arról, mit jelent a tolmács a közösség számára.

1. „Az kell, hogy jó legyen a fordító angolból, P. már jó. Jant hallgatom, P.-t csak úgy mellé, de P. nagyon jó."

2. „Janra figyelek, de P. nagyon jól fordít.”

3. „Nagyon tetszett P. stílusa is. P. nagyon jó volt, hiába nem értettem az angolt, de ahogy fordított, abban benne volt valami. A jó tolmácsról érezhető, tudható, hogy jól fordít, mert egyben van, amit fordít. Mindig is észrevettem a rossz tolmácsolást. Úgy éreztem, P. ott van abban a svungban, mint Jan. Ha P. volt a szűrő, amin át kellett jönnie, akkor őt egy nagyon jó szűrőnek éreztem. Nem volt hiányérzetem, hogy elveszik valamilyen jelentés, biztos volt ilyen, de nem éreztem. P. mindig
} 
elfogadta, ha valaki kisegítette, amikor nem értett jól valamit. Teljesen jó volt, imádtam, kedveltem is P.-t, stílusában is, meg ahogy dolgozott is."

4. „Nem beszélek angolul, de úgy éreztem, hogy abszolút átjött Jan mondandója P. fordításában, sikerült megragadnia a tartalmi és a hangulati lényeget is, nem volt hiányérzetem. Amikor megyek interjúra a tanítóhoz [egy másik közösségben], ott van, aki fordít, és ott szoktam azt érezni, hogy nem azt fordítja, amit mondok (minden évben más tolmács van). Nem tudom pontosan megfogalmazni, de nem éreztem a tanító részéről a megértést. Sokszor van olyan, hogy leülök a tanítóval szemben, és hiába nem értem angolul, de érzem, amit mond, és ez visszafelé is múködött. Nem nonverbális szinten, hanem egy másik szinten."

5. „P. nagyon jó, és az tetszik különösen, hogy magyarul szépen mondja, nemcsak megérti, hanem szépen fordítja, és bátran eltér a szó szerinti fordítástól. Mindkettejüket hallgatom, néha-néha van egy szó, amit Jan mond, és nem értem, de 95\%-ban megértem. P. néha kihagy dolgokat, de egyszerűen élvezem P. fordítását."

6. „Nem érdekel az, hogy P. hogy fordítja le, mert élvezem, érzem, hogy valami nagyon mély rezdül meg benne is, és nem akadok fenn azon, hogy pontos-e, kit érdekel."

7. „Nagyon szeretem, zseniálisan fordít, pont azért, mert nagyon emberien fordít, a humánum meg a humor annyira átjön. Nagyon szeretem Jant, de abszolút hozzáad, ahogy ő fordítja. Figyelem őt, mert annyira szép emberi, baráti, kedves fordulatokkal él, ami hozzáad egyértelműen."

8. „Eleinte abszolút nem értettem Jant, aztán elkezdtem járni angolórákra, és most már egyre többet értek, és egyre jobban érzem azt, hogy P. mit rak bele magyarul. Azt érzem, hogy P.-ben van egy iszonyú jó fogékonyság, és rá tud rezonálni arra a hullámra. És hogy egyszerűen fogalmaz Jan, és P. átrakja egy gyönyörü magyar nyelvre. Azt érzem, hogy nincs disszonancia benne, hogy valahogy úgy tudja az egészet átrakni, hogy él. És azt érzem, hogy ő igenis azt fejezi ki, amit a Jan ki szeretne fejezni, ha, mondjuk, hollandul beszélne, csak mivel van ez a nyelvi csatorna, ezért át kell rakni. Olyan mintha érzelmileg totál ott rezonálna vele, és egyben lennének, és ez nagyon ritka."

9. „Mind a kettőre figyelek, de nagyon sokszor hogyha eszembe jut, angolul jut eszembe, a Jannak a szavai jutnak eszembe, sőt, igazából P. szavai nem jutnak eszembe. De mindig meghallgatom P.-t is, és nekem ez annyira békés így, hogy kétszer lehet meghallgatni, ez hozzátesz. Egyrészt nagyon leleményesen fordít, másrészt teljesen észrevehetetlen, én biztos, hogy jobban hangsúlyoznám magam, nekem biztos jobban tetszene, hogy ilyen ügyes vagyok, meg ott ülök, ő meg ilyen nagyon kívül marad, nagyon szentségesen tudja ezt csinálni. Nagyon szeretem, ahogy P. fordít, nem is tudom elképzelni, mi lenne, ha más fordítana."

10. „Változó [hogy kire figyelek], Janra figyelek, valamikor észreveszem P.-t, főleg amikor érzem, hogy elakad. De P. nagyon jól fordít, tényleg, jól átadja a lényeget. Valamikor így átlényegít, amikor már nagyon arra törekszik, hogy a mondanivalót adja át, és akkor az meg tud csúszni már, és ezt észlelem. De ahogy P. fordít, az gyakorlatilag észrevehetetlen, ezt onnan tudom, hogy én elég háklis vagyok a fordításra, és porrá tudom rombolni a tolmácsot pillanatok alatt, ha hülyeséget csinál, és P. nem ilyen, ő teljesen belesimul ebbe, észrevehetetlen."

11. „Többet figyelek P. fordításaira, mert nem annyira jó még az angolom. Nagyon érzelmi úton közelít a dologhoz, jól csinálja. Nagyon jól megérzi, mit szeretne mondani a Jan, beleéli magát. Olyan, mintha a 20-as évek okkult páholyának spiritisztája lenne, átszellemül, szívvel csinálja, néha még hozzá is tesz."

12. „Figyelek a fordításra, én nagyon bírom. Ad egy olyan plusz értelmezést még a P. személye meg ahogy ő értelmezi, mintha kettőt hallanék. Ugyanazt két személytől is meghallgatni, az egy plusz töltetet ad. Meg ő nem az a fordító, aki nem adja bele magát meg a tudását a fordításba. Valahogy a kettő ad ki egy egészet."

13. „P. bevállalja, hogy ott van jelen, része a történéseknek.” 
irányában, aki egyébként sokat hezitált azon, hogy vakmerőség, bátorság vagy etikátlanság-e az ilyen nagyfokú stílusbeli eltérés. ${ }^{102}$

Az említettek mellett van még egy esemény, a záró tea-szertartás, ami ugyan a leginformálisabb program mind közül, de a tolmácsolás szempontjából még nehezebb, mint a többi. Ez az az esemény, amikor az elvonulás résztvevői teljesen szabadon kifejezhetik érzéseiket, megköszönhetik az élményeket. Ilyenkor előfordul versmondás, éneklés, próza - a 2014-es elvonuláson az egyik résztvevő egy hosszabb mesét mondott el „jó ízesen, pörgősen”. Ezeket a tolmács suttogó tolmácsolással fordítja a tanítónak. Az esemény végén pedig - már-már szertartásos jelleggel - a közösség megköszöni a tolmács munkáját.

Már az eddigiekből is egyértelműen látszik, hogy a tolmács fontos és megbecsült tagja a közösségnek - Jan Boswijk néhány éve éppen egy ilyen záróeseményen alkotta meg a „résztvevő tolmácsolás” fogalmát kifejezetten a közösség tolmácsára. Ez a - megszokott tolmácsolási szerepen túlmutató bevonódás a közösség életébe nyilvánvalóan a tolmácsra is hatással van, amit többek között az alábbi módon fogalmazott meg:

„Szerintem eleve a tolmácskodás bizonyos értelemben önmagad feladása, mert egy közvetítő vagy. Ehhez képest a pszicho témájú tolmácsolás még eggyel ilyenebb, és ehhez képest nekem a szanghában való tolmácsolás még eggyel ilyenebb. Tehát olyan értelemben az eléntelenedés nagyon itt van benne. És azt látom, hogy amióta a szanghában tolmácsolok - és biztos benne van az, hogy ez már egy otthonos közeg, hogy ismerősök vagyunk, nem egy új helyzet, de benne van ez a folyamat is, illetve talán köze lehet ahhoz, hogy egy buddhista közösségben tolmácsolok -, tehát azt látom, hogy egyre inkább hátrébb tudtam húzódni. Ez [a tolmácsolás] nagyon tud egy egotrip lenni, hogy ott vagy egy olyan helyzetben, amikor szolgálsz, és mégis lehet azt ilyen nagyon érdekes, paradox módon domborítani (vagy domborodik, ha nincsen jól megmunkálva), hogy milyen jól csinálod. Tehát hogy hátrahúzódsz, de mégse húzódtál hátra. Ebben a közegben különösen egy kulcsfigura vagy, érzelmi helyzetek vannak, spiritualitásról beszélünk, akár hogyha terápiás helyzeteket nézünk, ott

102 „Ha beülsz egy tanításra, vagy ott vagy az elvonuláson, és értesz angolul, akkor azt tapasztalod, hogy ő nagyon egyszerűen beszél, én pedig mívesen beszélek. Nagyon sokat reflektáltam erre, hogy akkor ez így rendben van-e. Ugye szoros emberfogásban ez azt jelentené, papírforma szerint, hogy make, do, have, csinál, történik - alapszavak magyarul is. Nagyon puritán lenne, ha egy az egyben adnám őt vissza - és akkor itt jön egy másik réteg, mert azt gondolom, hogy egy az egyben adom vissza, csak nem a szavak szintjén. De a visszajelzés az a szanghából, hogy ez így rendben van. Mert az történik, hogy ő nagyon egyszerüen beszél, én pedig elokvensen. De az, ami ott történik az én tolmácsolásomban az elvonulásokon, az azt hiszem, hogy nem P., hanem az a Jannal vagy a buddhizmussal átszűrt P., aki tolmácsol. Ez nem egy döntés kérdése, hogy én így beszélek, hanem abból sül ki, hogy ott van a Jan, hogy én adom ezt a nyitottságot, és ez az áramlás megtörténik." 
különösen kulcspozíció tud lenni. Tehát ez nagyon sok nyereséggel járhat az ego szintjén."

Mindezek nyomán nagyon határozottan az a kép alakult ki bennem, hogy itt egy olyan hosszú távú együttműködésről van szó, amely minden fél megelégedésére szolgál, és lehetőséget ad a folyamatos fejlődésre és összecsiszolódásra. A tolmács rendelkezik a szükséges felkészültséggel - szakmai háttérrel és nyelvtudással, érzékenységgel, ráhangolódási képességgel, diszkrécióval, arányérzékkel, „erős csatornaminőséggel” stb. -, amely képessé teszi egy ilyen speciális feladat ellátására. Ahogy fogalmazott, ez egy „spirituális profizmus”, ami nagyon eltér a hivatalos helyzetekben való tolmácsolásnál megkövetelt profizmustól. A tanítóval való összehangoltságuk egészen különleges ${ }^{103}$, amit azok is érzékelnek, akik először kerülnek kapcsolatba velük. A közösség tagjai pedig olyannyira elégedettek vele és a munkájával, hogy „van egy bekebelezési törekvésük” az irányában. Ami pedig még nagyon érdekes, hogy a tolmács úgy éli meg, hogy az evolúciója parallelnek tekinthető a közösség evolúciójával: ahogyan a közösség egyre önjáróbb, rugalmasabb, kreatívabb lett a tapasztaltságból adódóan, úgy járt be ő is egy utat a saját tolmácsolási minőségében. Ez olyan konkrét dolgokban is megfogható, mint például hogy a tanító érezhető fokozatos leválási szándéka és a közösség önállósodása mellett a tolmács is egyre kevésbé végzi „szoros emberfogásban” a munkáját.

Ha a fordítás nyelvi aspektusait nézzük, akkor a szertartásokhoz hasonlóan e tekintetben is az derült ki, hogy a megkérdezettek többsége számára a megértéshez elegendő a jelenlegi terminológiai pontosság, és különösebben nem

\footnotetext{
103 „Most már nem tudom hány év után az is egy markáns tapasztalat, hogy mi alig beszélünk amúgy azon kívül, hogy ő a program részeként beszél, és én lefordítom, és azon kívül, amit egyeztetünk a program, a tolmácsolás kapcsán. Az a benyomásom, hogy nem azért nem beszélünk szinte egyáltalán egymással, mert... hanem mert eszméletlen sok minden történik, de ez mind nem a szavak szintjén történik. Az elején talán egy kicsit beszélgettünk, egyszer mondta, hogy a fiatalkori önmagára emlékeztetem, és a humoromat nagyon szereti. De onnantól kezdve, hogy úgy igazán megismertem - ami megint egy furcsa dolog, mert ahogy épp mondom, nem beszéltünk egymással, mégis az az élményem, hogy igazán megismertem -, valahogy ez a nonverbális szinten van. Mert az alatt az öt nap alatt, azokban a helyzetekben és terekben, amikor tolmácsolok neki, akkor olyan intenzív a mi együttlétünk, amit azt hiszem, hogy csak energetikailag lehetne leírni. De én azt nem tudom leírni, csak érzékelem. Valahogy összeszoktunk egy másik szinten, és azóta egy nagyon mély nyugalom meg béke van bennem, és semmilyen hiány. Azt érzékelem, hogy nincsen szükség szavakra, mert valamilyen másik szinten kommunikálunk. Ezt egyszer meg is beszéltük, vagyis én egyszer elmondtam neki ezt a megélésemet, és azt mondta, hogy nagyon pontosan írom le, mert ő ugyanezt éli meg."
} 
zavarják őket a kisebb-nagyobb hibák (főleg, hogy a közösség tagjai között vannak olyanok, akik mélyebb ismeretekkel is rendelkeznek a buddhizmusról, és a tolmácsot kifejezetten nem zavarják a terminológiai javításaik). Ugyanakkor nagyon lényeges számukra az emberi minőség, a tanítások érzelmi dimenziójának, hangulatának, lényegének érzékeny átadása, egyébként a zen buddhizmus gyakorlati irányultságának, a megélés-belátás kitüntetett szerepének megfelelően. E tekintetben ez a tolmácsolási feladat nagymértékben eltér a megszokott (üzleti, konferencia- stb.) tolmácsolástól, és - függetlenül a hallgatóság méretétől - sokkal közelebb áll például egy személyes pszichoterápia tolmácsolásához.

\subsection{Problémamegoldás a hétköznapokban}

A kutatásom egyik kérdése az volt, hogyan jelenhetnek meg a mindennapi életvitelben a buddhista tan elvei, normái, értékei, hogyan tudják a közösség tagjai, az elvonuláson részt vevők felhasználni a problémamegoldáshoz az ilyen jellegű felkészültségeiket, és végső soron hogyan és milyen irányban változtatják meg ezek az ágensek és környezetük életét.

Bár az elvonulásokon is sokat beszélgettem a résztvevőkkel, ebben a fejezetben elsősorban az interjúkra fogok támaszkodni (és a jegyzetekben meglehetősen részletesen idézek belőlük). Ennek oka egyrészt az, hogy az elvonulás célja éppen a mindennapi életből való kiszakadás, a „lecsupaszítás”, a lelassulás, a befelé figyelés, az egyéni gyakorlás megerősítése, valamint új ismeretek, belátások szerzése és a meglévők elmélyítése, illetve a közösség szempontjából a kohézió növelése, a csoportidentitás megerősítése. Ezért bár az ottani beszélgetések során alkalmanként a mindennapi élet is előkerült témaként, de egyrészt a hangsúly máshova esett, és inkább az aktuális élmények és érzelmek jelentek meg, másrészt az elvonulás békés atmoszférája a meglévő problémákat is más színben tüntette fel. Volt, aki úgy fogalmazott, hogy az elvonuláson sokkal összeszedettebb, mint máskor, mások a közösségi élményt, a letisztulást, a feltöltődést, a határok érzékenyebbé válását, a harmóniát vagy éppen a fokozott tudatosságot említették, tehát mindenképpen valamilyen a hétköznapoktól minőségileg eltérő dolognak élték meg ezt az időszakot. Az interjúk azonban már a mindennapi élet különféle színterein: lakásban, munkahelyen, parkban, kávézóban készültek, más programok közé ékelve (ennek megfelelően esetenként időkorláttal), tehát az interjúalanyok mentális és 
érzelmi szempontból nem az elvonuláson megélt különleges állapotban voltak, hanem a mindennapi „üzemmódjukban”.

Az interjúkból egyöntetűen az derült ki, hogy nehezen szétszálazhatók a különféle felkészültségek, és a megkérdezettek a „fejlődéstörténetüket” egy szerves dolognak, olyan útnak tekintik, amelyen a különféle őket érő élmények és megszerzett tudások kiegészítő és megerősítő módon épülnek egymásra. Az elmondható, hogy a legtöbbjük életében mérföldkövet jelentett ${ }^{104}$ a buddhista tanításokkal vagy közösséggel való megismerkedés, az identitásuk tekintetében azonban a „buddhistaság” nem feltétlenül foglal el kiemelt helyet. Inkább arról van szó, hogy - sokszor évek vagy évtizedek alatt - belsővé tették a buddhista életszemléletet, morált (ezek elemei azonban nem kizárólagosan a buddhizmushoz tartoznak, máshonnan is meríthetők), és ez olyan módon alakította és alakítja a személyiségüket, világnézetüket, ami meghatározza az életük számos aspektusát: a problémák megoldását, a konfliktusok kezelését, az emberi kapcsolatokat, a fogyasztást, az étkezést, a szabadidő eltöltését, a munkahelyi környezet kialakítását, a személyes napirendet, a betegség/öregedés elfogadását stb. A megkérdezettek számos közös jellemzőjére derült fény: például hogy nem félnek „önismereti útra” indulni, és ezzel összefüggésben képesek kritikus szemmel tekinteni önmagukra; hogy fontosnak tartják az intellektuális szabadságot, nem szeretik a fanatizmust és a dogmatizmust; hogy keresik a lehetőségeket saját és környezetük életének jobbá tételére, akár a szakmájukon belül, akár azon kívül végzett (segítő vagy ismeretterjesztő) tevékenységgel; hogy fontosak számukra az

${ }^{104} \mathrm{Az}$ alábbi két megkérdezett mélyponton volt az életében, illetve a kapcsolatában, amikor találkozott a buddhizmussal:

„Azt, hogy meg tudtam változni, azt gondolom, hogy annak köszönhetem, hogy elkezdtem meditálni, és ez a dolog elkezdett komolyabban érdekelni. Ha úgy maradtam volna, ahogy 36-38 évesen voltam, az elég rossz újság lenne. Kaptam egy esélyt a buddhizmussal egy jobb életre, aztán meglátjuk, mit kezdek ezzel." (Boglárka)

„Meg akár a kapcsolatomban [segített], hogy hogy fogadom el az embereket. Ott voltunk abban a konfliktusban, és amikor annak vége lett, hogy én hogy tudtam benne maradni, és hogy tudtam elengedni, és hogy tudtam megbocsátani, és hogy tudtam elfogadni ôt, hogy lehet egy emberrel tovább élni, na abban nagyon sokat segített. Volt egy tanítás, amiben valami olyasmi volt, hogy felsorolta, mennyi rosszat tesz valaki, de ha van benne ez meg ez a jó tulajdonság, akkor ő... már nem tudom, sorba sorolta ezeket, hogy mennyi bünt tudunk elkövetni mások iránt, de ha látsz egy jó szálat, ami benne ott van, akkor neked arra kell figyelned, akkor ő már megmenthető. Elkezdtem azon gondolkodni, hogy itt van ez az ember, milyen jó és rossz tulajdonságai vannak, honnan hozta [őket]." (Judit) 
olyan értékek, mint a becsületesség, az őszinteség, a mértékletesség, az együttműködés és a tolerancia. Ugyanakkor mindezeknél nem mindig határozható meg egyértelműen, hogy mi az ok és mi az okozat, összességében inkább arról van szó, hogy az egyik oldalról az ezekre a kérdésekre eleve érzékeny emberek olyan közeget találtak maguknak, amelyben mások is hasonlóan gondolkodnak, és amely megerősíti őket ezeknek az értékeknek a helyességében, a másik oldalról pedig ez az adottságként meglévő érzékenység konkretizálódni tud, és sokoldalúan használható felkészültségekké válik.

Az interjúrészletekből az derül ki, hogy a mindennapi életvitelt leginkább úgy határozzák meg a buddhista tanítások, hogy az általuk képviselt elvek és attitűdök fokozatosan beépülnek a gondolkodásba, és belső késztetésként segítik a döntéseket bizonyos élethelyzetekben.105 Tehát hangsúlyosan nem arról van szó,

105 Az alábbiak a „Mennyire határozzák meg a buddhizmus elvei a mindennapi életviteledet?” kérdésre adott válaszok. Viszonylag hosszan idézem itt ezeket, mert jól érzékeltetik a változás jellegét és folyamatát.

„Szerintem nagyon, csak ezt nem veszem már észre, mert olyan régen foglalkozom vele, hogy nagyon átalakították a világról alkotott képemet, ahogy látom a dolgokat. Hogy hova utazok, meg mit csinálok, tehát klasszikus értelemben vett turistának már nem vagyok alkalmas, meg klasszikus értelemben vett fogyasztónak sem nagyon, ezek [a tanítások] persze legyürűznek ilyen szintekre is. Az, hogy mit eszem, engem annyira nem izgat, de ezek igen, ez egy nagy átalakulás szerintem, ami nem zárult le, zajlik folyamatosan." (Péter)

„Csak amennyire organikusan beleépült az életembe, annyira. Sok minden tudatosult bennem, sok ellenszenves dolgot észreveszek magamban, amit azelőtt nem vettem észre, de nem tartok be semmit azért, mert hogy ez buddhista, hanem az önkritikámat befolyásolta, meg bizonyos dolgokat jobban észreveszek. (...) [Vegetáriánus] voltam, most is lelkifurdalásom van, amikor néha eszem húst. Nem szeretek húst enni, ez ilyen hanyagság nálam, de marhát, disznót nem eszem régóta, csirkét, halat eszem. 3-4 évig voltam vega, akkor már buddhista voltam, de nem éreztem nyomást ezzel kapcsolatban. (...) Megváltoztatta az életemet, de nem azért, mert segítségül hívtam. Csomó dologba nem fogtam volna bele, ha nem kezdem el ezt az egészet. Ha van egy nagy probléma, állatira érdekel, hogy ők hogy közelítenek hozzá, hogy oldják meg, de azt nem érzem, hogy befolyásolja a döntésemet, mert eleve azt akarom, hogy befolyásolja. Tehát ha nagy probléma van, mindig segítségül hívom, de nem kész válaszokat várok, hanem érdekel, mit gondolnak róla." (Boglárka)

„Nagyon. Például nem ölök állatokat, nem csapkodom le a szúnyogot, bogarakat. [A húsevés] hullámzó, van, hogy egy hónapig nem eszem, máskor igen, de a buddhizmus előtt húst hússal ettem, most igyekszem alternatívákat keresni, meg most sokszor belülről jön, hogy nem kívánom, ilyen régen nem volt, de nem akarok álszent sem lenni. Két dolog van, az egyik, hogy nem olvasok el annyi felesleges dolgot, a másik pedig a becsületesség, hogy nem hazudok. (...) Teljesen átalakult az életem, régen sokszor kerültem pácba, ami most nincsen, de sokszor a puszta valóságban lenni is van olyan nehéz, mint pácban lenni. Vannak nagyon nehéz belső viharok, például ha meditációban jön elő valamilyen nehéz téma, vagy olyan belső tartalom, amit nehéz elfogadni, azon sokáig lehet kattogni." (Balázs)

„Az az érdekes, hogy a nehéz helyzetben nekem nem jut eszembe, hogy most akkor előszedjük a listát, hogyan is viselkednek a buddhisták, és akkor azt alkalmazom, hanem az szokott lenni, hogy ha utólag végiggondolom, ami történt, akkor elfog a jó érzés, hogy ezt sikerült végigcsinálnom anélkül, hogy 
hogy a megkérdezettek konkrét elvárásokhoz, dogmákhoz igazodnának, hanem a személyiségük fejlődik folyamatosan egy olyan irányba, ami által magukat jobbnak, az életüket teljesebbnek érezhetik. Emellett esetenként konkrét tanítások, gyakorlások is előkerülnek a hétköznapokban jellemzően úgy, hogy bizonyos tevékenységet végezve a megkérdezett felismeri benne a buddhista tanítást.106

Mások motivációinak jobb megértése, az empátia, a tolerancia is többször előkerült az interjúkban, aminél a megkérdezettek a buddhista tanításokra hivatkoztak - az együttérzés és a belátás fontosságára, valamint arra az axiómára, hogy az élet alaptermészete a szenvedés. ${ }^{107}$ Ugyanakkor nem gondolom, hogy az

gondolkodtam volna rajta. Több ilyen volt, de ezek maguktól jöttek. Észrevettem magamon, hogy jó irányba változom, és ennek örültem. De nehéz különválasztani, mi jön a buddhizmusból, mi jön az öregedésből, mindkét tényező bejátszik, mert egy kor után már nem annyira fontosak a dolgok. Nem tudom, pontosan mennyire határozza meg az életemet, de az a sejtésem, hogy jelentôsen bejátszik. Most úton vagyok valamerre, és csinálom azokat a dolgokat, amiket szeretek, amik jó érzéssel töltenek el, nem tudom, hogy a buddhizmus nélkül is ment volna-e ez." (Ádám)

„Engem a döntésekben segít. Sokat gyakoroltam meg olvastam, most már sok minden beépült, már nem vagyok úgy rendszeres gyakorló, de nálam van [az öt éberfigyelem-gyakorlat szövege], hordom magammal, és ha szükség van rá, elő tudom venni, emlékeztetőnek ott van mindig. (...) A gondolatiság a lényeges, a buddhizmusban megjelenő gondolatiság annyira érdekel engem, amennyire most segít élni." (Eszter)

„Az például, amit a Jan mondott a rákos szomszédjáról, hogy hogy segítsünk neki, hogy együtt lenni a szenvedésben vagy elfogadni, az hogy most akkor én részt veszek valakinek a szenvedésében [kórházban], ez majdnem mindennap [beugrik]. Ez így nagyon fontos. Az a baj, hogy nem tudok beszámolni, de azt tudom, hogy amikor beszélgetek valakivel, így [csettint] beugrik. Valami beépült már, és nyilván ami nem épült be teljesen, az jut eszembe. Mert ami beépült, az már nem jut eszembe." (Panni)

106 „A naplóm végébe bele is vannak írva a dalok, hogy ha elfelejteném a szövegét, a gate gate paragatét, meg mind a négyet, amit énekeltünk a gyertyagyújtáskor, meg a reggeli imát, az ilyen szinten is benne van a hétköznapjaimban." (Panni) A Pradnyápáramitá (szanszkrit: Prajñāpāramitā), azaz a tökéletes bölcsesség egyik szútrája (a mahájána buddhizmus egyik szövege, amelynek keletkezését Edward Conze az i.sz. 350 körüli időre teszi), a Szív szútra utolsó sora, a tökéletes bölcsesség mantrája. A teljes mantra: Gaté gaté páragaté páraszangaté bódhi szváhá (Gate gate pāragate pārasamigate bodhi swāhā). Jelentése: Bölcsesség, átmenet, átment, át a túlsó partra, megérkezett a túlsó partra. Szváhá!

„Amikor eszembe jut a sétáló meditációban, amikor már így eléggé lelassultam, rájöttem, hogy nincs stabilitásom, és ezt visszakötöttem oda, hogy én egyébként nem szoktam sétálni. Elkezdtem sétálni, így sokkal kevesebb benzint fogyasztok [nevet]. Viszont valamikor meg nincs kedvem fölszállni a BKV-ra, és akkor elkezdtem hosszúakat sétálni, és amikor elkezdek hosszúakat sétálni, akkor előbbutóbb eszembe jut, hogy nincs hova rohannom, tehát akkor nyugodtan lehet élvezni is azt, hogy sétálok. Ha viszont elkezdem élvezni, akkor eszembe jut, hogy ja, lehetne figyelni is a légzésemre. Olyan, mint egy ilyen oda-vissza ható folyam." (Márton)

„A jelent jobban meg tudom élni, de nagyon nehéz megítélni, mert együtt öregszem a buddhizmussal, ahogy az ember öregszik, ez jön amúgy is." (Boglárka)

107 „Amit nagyon észreveszek magamon, hogy van egy értékrendem, de el tudom ismerni, hogy vannak más értékrendek is, és ez így van még a szélsőjobbal is: nem elfogadó vagyok, de meg tudom érteni, 
empátia és a tolerancia kifejezetten a buddhista tanítások nyomán alakult volna ki, itt is inkább arról van, hogy az eleve meglévő tulajdonságokat igazolja vissza és erősíti meg a buddhista tanítás és a közösség (a tagok egyenként és a közösség mint egész is). Előkerült az önismeret és az önismereti munka, az önmagunkra való reflektálás fontossága is, nem függetlenül attól, hogy a megkérdezettek (és a közösség tagjainak) jó része segítő szakmában dolgozik, tehát számukra ez a kérdés egyébként is nagyobb súllyal esik latba. ${ }^{108}$

A személyes kapcsolatokra, önismeretre, magánéletre gyakorolt hatások mellett sokszor előkerült a munkában való alkalmazhatóság is. Erre a területre külön nem kérdeztem rá, de a mindennapi problémamegoldás kapcsán hangsúlyosan megjelent. A munkahelyi kapcsolatoknál az őszinteség, az empátia, a konfliktuskezelés fejlődése, az egymásrautaltság érzése jelenik meg, amelyek nemcsak a kollégákkal való kapcsolatokat és a közérzetet javítják, de hatékonyabbá és eredményesebbé is teszik a munkát. Ezen a területen nagyon nyilvánvalóan megmutatkozik a közösségben szerzett felkészültségek és Thich Nhat Hanh könyveinek hatása, tehát egyértelmű a kapcsolat a felkészültségek megszerzése és a problémamegoldási készségek javulása között.109

\footnotetext{
hogy mit ad az embereknek ez a nézet, és így máris tudok empatikusabb lenni velük. Tudom, hogy ez számukra egy hasonló közösség, mint nekünk a zen, összekovácsolja őket. Az embereknek szükségük van arra, hogy tartozzanak valahova, és sokszor látom, amikor találkozom ilyen emberekkel, hogy őket ez mozgatja." (Balázs)

„Az életem az üzenetem alapgondolata: akkor tudod megérteni a többi embert, ha a szenvedésüket megérted, mert az mozgat bennünket, milyen szenvedéseink munkálkodnak a mélyben." (Péter) Az életem az üzenetem (My life is my message) egy 2004-ben készült film Plum Village-ről és Thich Nhat Hanh-ról. Megtekinthető itt: https://youtu.be/fO5f75rKy20

„Toleránsabbá váltam, meg úgy a belátás, az insight, az sokat fejlődött, jobban elfogadom a világot, jobban látom, mi mozgatja." (Péter)

108 „Könnyebben megbirkózom a nehéz helyzetekkel, felismerem, hogy mennyi mindenben csak az egóm munkál." (Péter)

„Az önvizsgálat, az önismereti munka benne van az életemben, a szakmám miatt is, nap mint nap kell gyakorolni. De a személyes indítékokat el lehet rakni, és egy nagyobb egész szempontjából lehet a saját dolgaimra is rátekinteni." (Eszter)

„Meg egy csomó szembesülésem van saját magammal, hogy elfogadom, hogy a szenvedés van, de ha megérzem egy apró szelét annak, hogy valakinek az egészségével baj van a családban, akkor rögtön meg akarom oldani, és az ember akkor ezekre rálát, hogy hagyom-e neki, hogy megoldja a problémáját, vagy én akarom megoldani." (Judit)

109 „Soha nem kamuzok a munkahelyemen, és díjazzák is az őszinteséget. Azt veszem észre, hogy sokkal kevésbé vagyok elégedetlen, mint mások, hallom a munkatársaimat, hogy szidnak másokat, az életet, miért van meleg, hideg, de hát most ez van, sokszor észre sem veszek olyan dolgokat, amik másokat zavarnak, nem panaszkodom annyit, tágabb a komfortzónám." (Balázs)
} 
Végül pedig arra is rákérdeztem, hogy milyen konfliktusokkal szembesültek/szembesülnek a megkérdezettek a buddhizmus/buddhistaság kapcsán, és hogyan oldják fel ezeket. Olyan esetekre voltam kíváncsi, amelyeknél esetleg egy értékrendbeli ütközés miatt alakul ki konfliktus (tehát nem azért, mert előkerül a buddhizmus témája). Az derült ki, hogy elenyésző az ilyen konfliktusok száma, és összességében a buddhista tanhoz való kötődés, abból való merítés inkább elősegíti a konfliktusok megoldását, minthogy újabbakat generálna. Ennél a kérdésnél a megkérdezettek - a többi kérdéssel összehasonlítva - határozottan többet gondolkodtak, tulajdonképpen kifejezetten keresniük kellett konfliktusos eseteket, és nem is mindig sikerült találniuk. Egyetlen olyan téma került elő többször is, amelynél a konfliktus erőteljesebben jelent meg, az pedig a fanatizmus/tradicionalizmus/kizárólagosság kérdése. Ezektől a megkérdezettek

„Van olyan, hogy például munkakapcsolatban probléma-/konfliktuskezelésre használom, pl. ahogy a Harag írja, nagyon jól használható praktikus szinten is: úgy, hogy átjöjjön a cselekedetben, hozzáállásban, abban, amit mondok, de nem teszem láthatóvá." (Péter) A Harag Thich Nhat Hanh könyve.

„Ha dolgozom klienssel, és ő elmondja, neki mi a rossz, akkor tudom látni az érem több oldalát is, a munkán belül hasznosítható az empátia." (Balázs)

„A munkahelyemen egy olyan légkört próbálok teremteni, ahol nem divat furkálni egymást, ahol egyértelmű, hogy mi egymásra vagyunk utalva. Nagyon lényeges dolog, hogy nem tudunk mást, mint teamben dolgozni, ahhoz pedig ki kell, hogy lássunk önmagunkból, ahhoz szükség van az együttérzésre és annak a tudatára, hogy egymásra vagyunk utalva. Aki nem így dolgozik teamben, az olyan, mint amikor egy csónakban evezünk, de mozgatja a hajót állandóan. Az összehangolódás egy nagyon lényeges pont. Most már nem jön ide senki, hogy neki adjak igazat, megszúnt ez a típusú probléma. Teljesen átalakult az egész, intézeti szinten lehet érezni a hatást. Mindannyian a betegekkel dolgozunk, vannak közös témáink, ami mindenkit érint, és akkor össze lehet rakni a közös bölcsességet. A másik a tudatosság: az megnyithatja a megértés terét." (Eszter)

„Az, hogy figyelem így az embereket, sokat segít abban, hogy el tudjam fogadni őket. Ezt oda tudtam kötni ahhoz, hogy amikor elolvastam Thich Nhat Hanh könyvét [a Szívem, a Nap címü könyvről van szó], mintha annak a végén lenne az, hogy amikor konfliktus van a szerzetesek között, akkor hogy oldják fel a konfliktusokat. Leültetnek mindenkit, és mindenkinek a saját szempontjaiból részletesen el kell mondania, mi történt. Mintha minden modalitásból megnéznék azt, hogy mi történt, és így össze tudják rakni azt, hogy attól függően, ki milyen típusú, egészen másképp közelít meg egy konfliktust. Én ezt szoktam alkalmazni családterápiában, amikor a gyerekeket próbálom megértetni a szülőkkel, hogy az elfogadható-e, hogy neki egészen más érzékszervi szempontjai vannak, hogy miért nem akar egy taktilis gyerek gombos nadrágot felvenni, csak gumisat." (Judit)

„Meg az elfogadásban [segít], meg nagyon sokszor jut eszembe a munkahelyemen, hogy nagyon sokszor van az is bennem, hogy olyan könnyú beleállni abba, hogy én vagyok a terapeuta, ő meg a beteg. Ezt persze nagyon sok minden hozza, a beteg nyomása is, meg az én egóm is, meg néha egyszerűen szükség van arra, hogy hatalmon legyek, ha a beteg nem múködik együtt, de hogy ne az vigyen (ami sokat visz), hogy ez egy ilyen egoerősítés legyen. Hanem nagyon sokszor van bennem az, hogy nem különbözünk, tehát ez az »én benned vagyok, és te bennem vagy« [ez egy sokszor visszatérő tanítás]. Ez nagyon fontos." (Panni) 
kifejezetten távol tartják magukat, és vagy olyan helyzetekben találkoztak személyesen ilyen jellegű konfliktussal, amikor egy másik fél várta volna el a kizárólagosságot, vagy általánosan látnak ilyen problémákat a környezetükben, a világban. 110

110 „A konfliktusokat ôszinteséggel próbálom feloldani, de néha ezzel csak korbácsolom az indulatokat. De ha van is konfliktus, összességében békésebben oldom ezeket meg. Volt egy [nehéz családi helyzet], ott a türelem és az őszinteség sokat segített." (Balázs)

„Nem [kerülök konfliktusokba], én ezt úgy fogom fel, hogy a buddhista filozófia, szemlélet, értékek, ha ezeket tudom gyakorolni, az jó nekem, jó a körülöttem lévőknek is, és én ezzel megelégszem. Nem csinálok semmi különöset, meg szerencsére olyan barátaim vannak, akikkel szeretjük egymást annyira, hogy ilyenen ne lepődjünk meg." (Ádám)

„24 évesen odakerültem a nagymamához, akkor volt olyan időszak, amikor legalább napi három órát meditáltam (nem jártam közösségbe, egyedül gyakoroltam), és fél év alatt felápoltam a nagymamát, aki ágyban fekvő beteg volt, 27 kiló volt. Akkor már magamban megtaláltam a nyugalmat, tudtam neki segíteni. Ez egy szülői környezetben biztos vad lett volna, hogy én napi három órát ülök, biztos beleszóltak volna, vagy akár egy párkapcsolatban, de a nagymamának ez külön jó volt. A szüleimnek ez úgy csapódott le, hogy vegetáriánus lettem azonnal, mindketten bombáztak a húsos ideológiával, kaptam a könyveket, próbáltak lebeszélni, de mivel tök egészséges voltam mindig, nem nagyon lehetett ezzel mit kezdeni. Aztán már főztek vega kajákat. (...) Alapból azt szeretem, ha mindennap tudok gyakorolni, ez nagyon fontos nekem, a tanításhoz is fontos, fókuszban vagyok, meg oda tudok figyelni. Az élethez fontos, hogy én én vagyok, és igazán ott vagyok. Főleg párkapcsolat idején minden borul, de akkor meg az a jó, hogy minden borul. Akkor nem annyira függök ezektől. Olyankor is gyakorolok, csak nem annyit. Nem vagyok ennyire merev, olyankor tényleg volt, hogy ettem húst, meg ittam egy kis alkoholt. Az alapállapotom az, hogy nem eszem húst és nem iszom alkoholt, egyébként soha nem fordul elő az ellenkezője, kivéve párkapcsolatban. Egy másik ember kedvéért hajlandó vagyok borítani, és nagyon élvezem. De persze egy napon kellene összehozni ezeket a szélsőségeket." (Nikolett)

„Azt időnként megkapom, hogy persze, ezt te azért mondod, mert buddhista vagy. És akkor ezt így lehet tisztázni egy idő után, hogy ez miből jön, tehát hogy a gyakorlás vagy az adott helyzet vagy tudás. De egyébként nem, én nem akarok senkit megváltani, meg elmagyarázni, hogy ez jó, hanem nekem ez jó, amíg valaki ezzel nem akar engem korlátozni, addig nem lesz belőle konfliktus. Addig oké. És észre sem veszi, hogy én most ezt csinálom, ha úgy tetszik, úgy belesimul az életbe." (Márton)

„Régebben volt ilyen, de már nincs, illetve kevésbé van. De azt látom, hogy amikor tradíciókba próbál menni valaki, az egy állandó feszültségforrás, és azt nagyon nehéz feloldani. Mindenhol ezt látom, a kereszténység/buddhizmus viszonya az államhatalomhoz, de bárhol, teljesen általános probléma, egyes embereken is észreveszem. Ilyen a Jan is, a Dharma-tanító viszonya a rendhez. Ez eleve egy konfliktus, mennyire tartsa magát a tradícióhoz, ez bizonytalanította el, mennyire igazodjon az ottani dolgokhoz. Tavaly óta ez ütközik ki rajta, korábban ez nem volt." (Péter)

„A jógatáborban úgy szoktam csinálni, hogy kiteszek magamra egy mauna (hallgató) cédulát, és egész végig hallgatok. Őket kifejezetten irritálni szokta, hogy nem szólalok meg, mert ott azért van karattyolás, de én ezt nem szeretem, mert kifejezetten elviszi az energiát, ami a gyakorlásból és a meditálásból felgyülemlik. Azért is szoktam így, mert ott azért fanatikusok is vannak, és volt nem egyszer olyan kisebb-nagyobb konfliktus, hogy ugye én más iskolában is tag vagyok, és nem vagyok egyáltalán fanatikus, és ebből voltak problémák, hogy én akár bírálom a mestert, vagy nem értek teljesen egyet azzal, ami ott van. Ott az lett volna az elvárás, hogy teljesen vakon követni a mestert, és csak oda tartozni. Úgy lenne elvileg, hogy ha már valahova tartozol, akkor nem kell, hogy amiatt lemondjál erről, de ha már itt beavatott vagy, akkor máshova már ne járj." (Nikolett) 


\section{5. Összefoglalás, konklúziók}

Az értekezésben a kommunikáció intézményeinek, színtereinek és ágenseinek fogalmai mentén igyekeztem feltárni azt, mit jelent az egy magyarországi buddhista közösség elvonulásain részt vevők számára a buddhizmus, a közösség, az elvonulás; hogyan tudják az itt megszerzett felkészültségeiket felhasználni a mindennapokban (a magánéletükben és a munkájukban), esetlegesen milyen konfliktusokkal szembesülnek; mennyire értik meg a buddhista tan elveit magyarul, illetve angol nyelven közvetítve; hogyan élik meg az elvonulás szakrális dimenzióját; és egyáltalán, hogyan illeszkedik ez az egész a nyugati buddhizmus keretébe. Ehhez először áttekintettem az olyan intézmények bizonyos megközelítéseit és meghatározásait, mint a kultúra, a vallás és a nyelv, majd beszámoltam a buddhizmus nem vallásként való értelmezési lehetőségeiről, valamint egyes tudományos területek buddhizmus iránti érdeklődéséről, továbbá bemutattam néhány buddhista terminus fordítási lehetőségeit is. Az elméleti fejtegetések során klasszikus és kortárs szakirodalomra is támaszkodtam, a gyakorlati kutatást pedig egy magyarországi buddhista kisközösségben végeztem az elvonulásokon való résztvevő megfigyeléssel és mélyinterjúkkal.

A kutatáshoz a kommunikációs elméletek közül a participációs elmélet bizonyult a legmegfelelőbbnek, mivel ennek esetében egy olyan elméleti keretről van szó, amelyben a kommunikáció fogalma a participáció fogalmára épül, és amelyben az ágensek felkészültségekben való kölcsönös részesedéséről mint a problémamegoldás szükséges feltételéről gondolkodunk. A kultúrát egy értelemadó rendszerként tekintettem, amelyen keresztül az ember olyan fogalmakat, viselkedési mintákat és eszközöket sajátít el, amelyekkel az adott társadalomban

\footnotetext{
„Mindig csodálkoztam azon, ha valaki ilyen nagyon fanatikusan hisz valamiben, és mindig az volt az érzésem, hogy kicsit »irigyeltem« [mutatja az idézőjelet], mert van abban valami jó, amikor valaki fanatikus tud lenni. Ad valami olyan energialöketet, és sokkal jobban leegyszerüsíti a világot, nem kell egy csomó helyzetben döntéseket hozni, és annak mentén nagyon erőteljesen meg tudja határozni magát valamiben, akár egy karrierben. Nekem az a problémám (most már elengedem ezt), hogy sokszor én milyen módszerrel dolgozom vagy hogy müködöm itt ebben a szakmában, ahol rohadt sok irányzat van, és nyilván belekaptam egy csomóba, de azt látom, hogy az van karrierben elórébb (de ez biztos más szakmában is így van), aki kitalál magának egy utat, és azt elég fanatikusan hirdeti is, meg megy utána. Mindig voltak bennem kérdőjelek egy csomó irányzattal kapcsolatban." (Judit) „Jógán mondták ezt, hogy mert a jóga egész embert kíván. Oké, akkor te jógás vagy, én meg ember vagyok, aki jógázik. De ez csak egy példa, máshol is látni ezt." (Márton)
} 
funkcionálni tud, és kulturális tudása, felkészültségei révén jelentéseket képes előállítani. A nyelvet annak mérsékelt relativista felfogásában értelmeztem: hogy az egyedi lehetőségeink, kognitív erőforrásainak, tehát összességében gondolkodásunk, valamint érzésvilágunk alapjai tekintetében egyetemesek vagyunk - ugyan vannak különbségek a kultúrák és a nyelvek között, ezek azonban nem jelentenek végső akadályt a megértés számára. A mélyinterjúkból az a kép bontakozott ki, hogy a megkérdezettek érzékelik a nyelv jelentette korlátokat (a buddhizmus szövegeinek eredeti nyelve, a tanító anyanyelve, a tanítások nyelve és a tolmácsolás miatti többszörös közvetítésből fakadó újraértelmezések megléte világos számukra), azonban ez nem lehetetleníti el a megértést. Ennek oka egyrészt az, hogy bár úgy vélik, valamilyen keleti nyelv ismeretével a buddhista szövegek, kifejezések újabb jelentésrétegei tárulhatnának fel számukra, de a személyes életükben való alkalmazáshoz elégséges az a tudás, amit a nyugati buddhizmusból magyarul, illetve angolul nyerhetnek. A másik ok pedig annak érzése, hogy az átadások nem csupán a szavak szintjén történnek meg.

A vallás fogalmának meghatározása a téma szempontjából nehezebb volt, de a legplauzibilisebbnek William James megközelítése bizonyult, aki az intézményes vallásosság helyett a személyes élményt helyezi a középpontba, és vallásnak az egyén magányosan megélt érzéseit, tetteit és tapasztalatait tekinti, amennyiben azok megragadhatók úgy, mint amelyek kapcsolatban állnak az általa isteninek tekintett dologgal. A mélyinterjúkból az derült ki, hogy ugyan a megkérdezettek jellemzően nem tartják vallásnak a buddhizmust - sokkal inkább életfilozófiának, pszichológiának, egy olyan támpontnak vagy rendszernek, amely segít az életben a James-féle értelemben (egy-két kivétellel) tekinthetők vallásosnak vagy vallásos érzülettel rendelkezőnek. (Ez azonban egy kutatási célú, általánosító és objektiváló meghatározás, amelynek alkalmazásával nem vitatom el a megkérdezettek önértelmezésének igazságát.) Leírhatjuk ezt az autonóm vallásosság vagy a maga módján vallásosság, illetve akár a spirituális érdeklődés/útkeresés terminusaival is.

A közösség tekintetében elmondható, hogy a követett buddhista irányzat a Thich Nhat Hanh nevéhez köthető „mindennapi buddhizmus” vagy „elkötelezett buddhizmus”, amely közelebb áll a nyugati ember gondolkodásmódjához. A megkérdezettek saját bevallásuk szerint is a nyugati buddhizmushoz tudnak kapcsolódni, és jól látják azt, hogy az ázsiai emberek buddhizmusa jóval 
intézményesebb, a klasszikus értelemben véve vallásos jellegű. Ennek nyugati megvalósítását nem tartják lehetségesnek, azonban azt gondolják, hogy a nyugati változat megfelelő ahhoz, hogy vezérfonalul szolgáljon a mindennapokban, mert csak ez egyeztethető össze az életvitelükkel. Ők maguk változó mértékben és módon gyakorolnak, a napi szintű meditációtól vagy tanítások napi hallgatásától kezdve addig, hogy inkább csak az elvonulásokon vesznek részt, és a menedékvétel során felvett öt gyakorlatban szereplő elveket igyekeznek az életükben többé-kevésbé megvalósítani.

A buddhizmushoz és különösen a nyugati buddhizmus való kapcsolódás egy másik oka a tudományos világképpel való (más vallásokkal összehasonlítva) könnyebb összeegyeztethetőség. A közösség tagjai döntő többségükben felsőfokú végzettségű, urbánus emberek, akik vagy valamilyen tudományos területen tevékenykednek, vagy más értelmiségi munkát végeznek. Nagy számban vannak közöttük pszichológusok, terapeuták és más segítő foglalkozásúak, beleértve a közösség tanítóját és tolmácsát is. Ennek megfelelően nem meglepő, hogy fontos számukra a racionális gondolkodással való összeegyeztethetőség. A szertartásokkal, rítusokkal való kapcsolatuk ambivalens, de jellemzően szeretik vagy elfogadják őket - azzal a kitétellel, hogy nem feltétlenül a szakrális jellegüket élik meg (bár arra is vannak példák), hanem inkább az érzelmi oldalukat, az emberi életben és közösségekben betöltött szerepüket hangsúlyozzák. Összességében megfelelőnek tartják a szertartások arányát az elvonulásokon.

A közösség szerepével és jelentőségével kapcsolatban az derült ki, hogy a közösségben való tagságot sokféleképpen élik meg a megkérdezettek. A részvétel nagy vonalakban leírható a „mag” és a „holdudvar” fogalmaival, azonban ezek között nem éles a választóvonal, ráadásul jelenleg éppen változik is a közösség e tekintetben. Az arról alkotott vélemény, hogy a közösség mennyire funkcionál kollektív ágensként, összefügg egyrészt az egyéni szerepvállalás és az elkötelezettség szintjével, másrészt a közösséggel kapcsolatos elvárásokkal is. Összességében a közösség meglehetősen rugalmasan kezeli a tagságot, ami egyrészt ronthatja a kohéziót, másrészt azonban könnyebbé teszi a bekapcsolódást. A tanító fontos szerepet tölt be a közösség életében, sokan kötődnek hozzá bizonyos szinten, de általában azt gondolják, a közösségnek önmagában is meg kell állnia. Az azonban egyértelműen bebizonyosodott, hogy a közösség elvonulásain a tanító személye 
nagy vonzerôt jelent, a résztvevők hiteles embernek tartják, és szívesen tanulnak tőle. A közösség összetételéből következően a tanító pszichológiai irányultsága kifejezetten előnyként jelenik meg.

Az elvonulás funkciója a kutatás eredményei szerint (azon kívül, hogy az elvonuláson való részvétel a feltétele a közösségben való tagságnak) a kiszakadás a mindennapi élet forgatagából, a befelé figyelés, az elme lecsendesítése, az empátia erôsítése, az önfejlesztés, a „jelenben levés”. Az elvonuláson való részvételt motiválhatja a kíváncsiság, a nehéz élethelyzetre való megoldáskeresés, a rekreáció igénye és a közösségben való gyakorlás (illetve a régebbi tagoknál a közösség más tagjaival való találkozás) lehetősége is. A közösség meglétét mindenki fontosnak tartja, abban azonban eltérések mutatkoznak, ki mennyire igényli a közösség támogatását a saját gyakorlásához. Van, aki egyedül is ugyanolyan jól tud gyakorolni (meditálni vagy más módon), másnak a közösségi gyakorlás jelentős támogatás ad. Olyan is van, aki inkább csak az elvonulásokon gyakorol aktívan.

A kutatásból az is kiderült, hogy a buddhista tanításból, a közösségben és kifejezetten az elvonulásokon a résztvevők olyan felkészültségeket szereznek, amelyek érzékelhetően segítik őket a problémamegoldásban. Ez igaz mind a magánéletre, mind a munkavégzésre és a munkahelyi kapcsolatokra. A buddhista tanítások leginkább úgy határozzák meg a mindennapi életvitelt, hogy az általuk képviselt elvek és attitűdök fokozatosan beépülnek a gondolkodásba, és belső késztetésként segítik a döntéseket bizonyos élethelyzetekben. A megkérdezettek arról számoltak be, hogy olyan felkészültségeket szereztek a buddhizmus révén, amelyek jelentősen befolyásolták és befolyásolják az emberi kapcsolataikat: jobban bele tudják magukat élni mások helyzetébe, ezáltal toleránsabbak, empatikusabbak, megértőbbek lettek. Saját magukat illetően pedig: nagyobb önismeretre tettek szert, könnyebben megbirkóznak a nehéz helyzetekkel, és jobban kezelik a konfliktusokat. Mivel a buddhizmust nem vallásként élik meg, nem jelent számukra gond ot a más vallásokkal való esetleges összeegyeztetés sem. Láttunk ugyan példát erősebb kettős vallási identitásra is, de a megkérdezettek többsége inkább csak egy valláshoz kötődőként definiálja magát, és ez is csak gyengébb kötődést jelent. Emellett csak kevés konfliktussal szembesülnek a „buddhistaságuk” miatt, alapvetően azért, mert nem akarják másokra ráerőszakolni a saját nézeteiket. 
A kiinduló hipotéziseket tehát igazolta a kutatás:

1. A buddhizmus rendelkezik azzal a rugalmassággal, ami befogadhatóvá teszi a nyugati ember számára, így alkalmas lehet az életvitele vezérfonalának. Ez esetünkben a buddhizmusnak a „mindennapi” vagy „elkötelezett” buddhizmusban megvalósuló formája. E formát ugyan nem tekinti mindenki „igazi” buddhizmusnak, és még többen nem tekintik vallásnak, legfeljebb valamilyen kvázi-vallásnak, de az értekezés témája nem az ezzel kapcsolatos állásfoglalás volt. A nyugati és azon belül is a mindennapi buddhizmus lehetővé teszi az eltérő mélységű kapcsolódást, bevonódást, és az, hogy nem vár el kizárólagosságot (megengedi akár a kettős vallási identitást is), vonzerőt jelent. Emellett ez a forma összeegyeztethető a mindennapi életvitellel is. Az eredeti buddhista tanítások megértését ugyan korlátozza a keleti nyelvek hiányzó ismerete, valamint az angol nyelven tartott tanítások fordítása során is vesznek el (és keletkeznek is újabb) jelentések, ez nem gátolja az érdemi befogadást.

2. Bebizonyosodott, hogy a megkérdezetteknél a közösségben szerzett felkészültségek hatékonyan segítik a problémamegoldást a mindennapi életben. E felkészültségek megszerzésének egyik központi tere az elvonulás, ahol igen intenzíven zajlik a felkészültségek megszerzése és bővítése: tanítások, közösségi megosztások, különféle meditációk és szertartások, valamint informális beszélgetések révén. Ezenkívül a csendes időszakok éppúgy szolgálnak a felkészültségek megszerzésének terepeként, mint az egyéb programok. A megkérdezettek mindannyian a problémamegoldási és konfliktuskezelési készségeik fejlődéséről számoltak be a buddhista gyakorlás kapcsán. Összességében elmondható, hogy a közösségben való részvétel és a buddhista gyakorlás hozzájárul az önismeret fejlesztéséhez, az emberi kapcsolatok elmélyítéséhez és általában az életminőség javításához. 


\section{I. függelék: Gyakorlatok}

\section{Az öt éberfigyelem-gyakorlat szövege}

Fivéreim és nővéreim a közösségben, itt az ideje, hogy együtt szívből elrecitáljuk az öt éberfigyelem-gyakorlatot. Az öt éberfigyelem-gyakorlat a buddhizmus egész világra kiterjedő spiritualitását és erkölcsét képviseli. Ez az öt gyakorlat a Buddha tanításainak kézzelfogható kifejeződése, melyeket a Négy Nemes Igazságról és a Nemes Nyolcrétű Ösvényről adott, amely a helyes megértés és az igaz szeretet ösvénye, s amely gyógyuláshoz, átalakuláshoz és boldogsághoz vezet mind számunkra, mind pedig a világ számára. Ha az öt éberfigyelem-gyakorlatot végezzük, azzal kialakítjuk a kölcsönösen függő létezés belátását, vagyis a helyes nézetet, mely képes felszámolni minden megkülönböztetést, türelmetlenséget, haragot, félelmet és kétségbeesést. Ha az öt éberfigyelem-gyakorlatnak megfelelően élünk, akkor már a bódhiszattva ösvényén járunk. Tudván, hogy már ezen az ösvényen járunk, nem veszünk bele az életünkkel kapcsolatos zavarodottságba a jelenben, sem pedig a jövőtől való félelmekbe.

\section{Az élet tisztelete}

Tudatában lévén a szenvedésnek, melyet az élet kioltása okoz, elköteleződöm amellett, hogy kialakítom a kölcsönösen függő létezés belátását és az együttérzést, valamint elsajátítom azokat a módszereket, melyekkel az emberek, állatok, növények és ásványok életét megóvom. Eltökélt vagyok, hogy nem ölök, nem engedek másokat ölni, és nem támogatok semmilyen ölést a világon, a gondolataimban vagy az életmódommal. Látva, hogy az ártó cselekedetek a dühből, a félelemből, a mohóságból és a türelmetlenségből fakadnak, melyek viszont a dualisztikus és megkülönböztető gondolkodásból erednek, nyitottságra, megkülönböztetéstől való mentességre és a nézetekkel szembeni nem kötődésre teszek szert, hogy átalakítsam az erőszakot, a fanatizmust és a dogmatizmust önmagamban és a világban. 


\section{Igaz boldogság}

Tudatában lévén a szenvedésnek, melyet a kizsákmányolás, a társadalmi igazságtalanság, a tolvajlás és az elnyomás okoz, elköteleződöm amellett, hogy gyakorlom a nagylelkűséget a beszédemben, a gondolkodásomban és a cselekedeteimben. Eltökélt vagyok, hogy nem lopok és nem birtoklok semmit, ami másoké kellene, hogy legyen; és megosztom az időmet, energiámat és anyagi javaimat az erre rászorulókkal. Gyakorolni fogom, hogy a dolgok mélyére nézzek azért, hogy meglássam: mások boldogsága és szenvedése nem válik el az én boldogságomtól és szenvedésemtől; az igaz boldogság nem lehetséges megértés és együttérzés nélkül; s a gazdagság, hírnév, hatalom és érzéki örömök hajszolása rengeteg szenvedést és kétségbeesést szülhet. Tudatában vagyok annak, hogy a boldogság tudati hozzáállásomtól függ, nem pedig külső feltételektől, s hogy egyszerűen azáltal boldogan élhetek a jelenben, hogy emlékezem rá: már most több mint elég feltétel teljesült számomra ahhoz, hogy boldog legyek. Elköteleződöm amellett, hogy gyakorolni fogom a helyes megélhetést azért, hogy segíthessek az élőlények szenvedésének csökkentésében a Földön, valamint a globális felmelegedés folyamatának megfordításában.

\section{Igaz szeretet}

Tudatában lévén a szenvedésnek, melyet a szexuális eltévelyedés okoz, elköteleződöm amellett, hogy felébresztem a felelősséget, és elsajátítom azokat a módszereket, melyekkel az egyének, a párok, a családok és a társadalom biztonságát és tisztességét megvédhetem. Tudván, hogy a szexuális vágy nem szeretet, s hogy a gyötrő vágytól vezérelt szexuális tevékenység mindig ártalmas önmagamra és másokra nézve, eltökélt vagyok, hogy nem bocsátkozom szexuális kapcsolatokba igaz szeretet és mély, hosszú távra szóló elkötelezettség nélkül, melyről a családom és a barátaim is tudnak. Minden tőlem telhetőt megteszek, hogy megvédjem a gyermekeket a szexuális bántalmazástól, és megelőzzem a párok vagy családok szexuális eltévelyedésből fakadó széthullását. Látva, hogy test és tudat egy, elköteleződöm amellett, hogy elsajátítom azokat a módszereket, melyekkel megfelelő mederbe terelem a szexuális energiáimat és kialakítom a szerető 
kedvességet, az együttérzést, az örömöt és az elfogadást - amely az igaz szeretet négy alapeleme - saját magam és mások nagyobb boldogságára. Az igaz szeretetet gyakorolva tudjuk, hogy gyönyörűen lépünk át a jövőbe.

\section{Kedves beszéd és figyelmes hallgatás}

Tudatában lévén a szenvedésnek, melyet a meggondolatlan beszéd és mások meghallgatásának képtelensége okoz, minden erőmmel törekszem a kedves beszéd kialakítására és az együtt érző hallgatásra, hogy enyhítsem a szenvedést, és előmozdítsam az egyetértést és a békességet magamban és más emberek, etnikai és vallásos csoportok, valamint nemzetek között. Tudván, hogy a szavak boldogságot és szenvedést egyaránt okozhatnak, eltökélt vagyok, hogy csak igazat mondok, olyan szavakkal, melyek serkentik az önbizalmat, az örömöt és a reményt. Eltökélt vagyok, hogy amikor harag jelenik meg bennem, nem fogok megszólalni. Gyakorolni fogom a tudatos légzést és sétát, hogy felismerjem a haragomat, és a mélyére nézzek. Tudom, hogy a harag a téves észlelésemben gyökeredzik, valamint abban, hogy nem értem a szenvedést sem önmagamban, sem a másik emberben. Olyan módon fogok beszélni és hallgatni, hogy az segítségére legyen önmagamnak és másoknak, átalakítva a szenvedést és megmutatva a kiutat a szorult helyzetekből. Eltökélt vagyok, hogy nem terjesztek olyan híreket, amelyekről nem tudok biztosat, és nem ejtek ki olyan szavakat, melyek nézeteltérést és viszályt szítanak. Gyakorolni fogom a helyes igyekezetet, hogy erősítsem a megértésre, szeretetre, örömre és elfogadásra való képességemet, és fokozatosan átalakítsam a tudatom mélyén rejlő haragot, erőszakot és félelmet.

\section{Táplálás és gyógyítás}

Tudatában lévén a szenvedésnek, melyet a meggondolatlan fogyasztás okoz, elköteleződöm amellett, hogy megőrzöm saját magam, a családom és a társadalom testi-lelki egészségét, mégpedig azzal, hogy tudatosan eszem, iszom és fogyasztok. Gyakorolni fogom, hogy alaposan megvizsgálom, miként fogyasztom a négyfajta táplálékot, nevezetesen az ehető táplálékot, az érzékszervi benyomásokat, az 
akaratot és a tudatosságot. Eltökélt vagyok, hogy nem játszom szerencsejátékot, nem fogyasztok alkoholt, kábítószert vagy más olyan dolgot, amely méreganyagokat tartalmaz, beleértve bizonyos honlapokat, elektronikus játékokat, tévéműsorokat, filmeket, újságokat, könyveket és beszélgetéseket. Gyakorolni fogom a jelen pillanathoz való visszatérést, hogy kapcsolatban legyek a bennem és körülöttem lévő gyógyító és tápláló dolgokkal, s ne engedjem, hogy a megbánás és a szomorúság visszarántson a múltba, sem hogy az aggodalmak, félelmek és sóvárgások elvonják a figyelmemet a jelen pillanattól. Szemlélődni fogok a kölcsönösen függő létezésen, és fogyasztásommal igyekszem fenntartani saját testem és tudatom, valamint családom, a társadalom és a Föld kollektív testének és tudatának békéjét, örömét és jóllétét.111

\section{A föld három érintése gyakorlat ${ }^{112}$}

\section{Megérintem a földet, és kapcsolatba kerülök a szellemi és vér szerinti őseimmel és utódaimmal.}

(Harang. Mindenki megérinti a földet.)

Látom szellemi tanítóimat, mind az élőket, mind a már eltávozottakat. A béke, bölcsesség, szeretet és boldogság formájában jelen vannak bennem. A szellemi tanítóim közé tartozhat a Buddha, Krisztus és a különböző hagyományokhoz tartozó szentek számos nemzedéke. Látom, hogy mindannyian bennem vannak, és én bennük vagyok. Ha voltak olyan szellemi tanítóim vagy idősebb dharmatestvéreim, akik nem nőttek fel az elvárásaimhoz, elfogadom őket tökéletlenségeikkel, és felismerem, hogy én magam sem vagyok tökéletes, és ők az én részeim is. Látom szellemi utódaimat, tanítványaimat és mindazokat, akikkel megosztottam a spirituális életet. Látom ifjabb dharmatestvéreimet. Ők a szellemi őseim békéjének, bölcsességének, szeretetének és boldogságának folytatódásai. Amikor nem olyan megértőek és együtt érzőek, ahogyan én szeretném, kitárom szívemet, és együttérzéssel elfogadom őket. Minden szellemi utódomat a testem és elmém

\footnotetext{
111 http://www.szelidmosoly.hu/index.php/tanitas/gyakorlatok/18-5-eber-figyelem-gyakorlat (Utolsó letöltés: 2016. február 20.) 112 Thich Nhat Hanh-tól származó gyakorlat.
} 
csodálatos folytatódásaként látom. Látom vér szerinti őseimet, és figyelmemet erényes tulajdonságaikra, testük és elméjük erejére irányítom, és érzem, hogy ezek táplálnak engem. Ha őseimben gyarló tulajdonságok vannak, azokat gyengéden a földre helyezem, hogy az együttérzés és elfogadás átalakítsa őket. Látom, hogy mindannyian bennem vannak, és én bennük vagyok. Elképzelem vér szerinti utódaimat: gyermekeimet, unokáimat, unokaöcséimet és unokahúgaimat. Látom erősségeiket, erényeiket és tehetségüket, és örömömet lelem ezekben. Látom gyengeségeiket is, amelyeket gyengéden a földre helyezek, hogy virággá változzanak. Minden vér szerinti utódomat testem és elmém csodálatos folytatódásaként látom. Az őseim és utódaim mind a részeim. Én ők vagyok, ők pedig én. Nincs különálló énünk. Együtt létezünk az örök mozgásban lévő, kezdet és vég nélküli élet gyönyörű áramlásában.

(Harang)

\section{Megérintem a földet, és kapcsolatba kerülök minden emberrel és minden} fajjal, aki és amely ebben a pillanatban velem együtt él ezen a világon.

(Harang. Mindenki megérinti a földet.)

Egy vagyok az élet csodálatos és ragyogó szövedékével, amely minden irányba kiterjed. Látom a szoros kapcsolatot köztem és a többiek között, s azt, ahogyan osztozunk a boldogságban és a szenvedésben. Látom, hogy egy vagyok azokkal a nagyszerű lényekkel, akik szinte mindenhol fellelhetők. Ezek a lények a részeim. Félelem nélkül tekintenek a születés, halál, boldogság és szenvedés különböző formáira. Általuk megérintem a nem félelmet magamban. Egy vagyok azokkal az emberekkel, akikben az elme békéje, a megértés és a szeretet megfelelő mértékű, akik képesek megérinteni azt, ami csodálatos, tápláló és gyógyító, és akik képesek szerető szívvel magukhoz ölelni a világot és kiterjeszteni óvó karjukat. Én is képes vagyok erre. Hozzájuk hasonlóan bennem is béke, öröm és szabadság lakik, s én is képes vagyok eloszlatni a körülöttem élők félelmét és örömöt nyújtani nekik. Látom magamat a nagyszerű lényekben, és a nagyszerű lényeket magamban. A szenvedés, amellyel szembe kell néznem, nem a saját szenvedésem, hanem a kozmosz szenvedése. Szenvedek a cunamiban és a haiti földrengésben. Szenvedek, amikor kivágják az erdőket. Amikor a kis halat üldözi a nagy hal, félelmet érzek. Ez a félelem 
nem a saját félelmem, hanem az összes nemzedék és az összes élőlény félelme. Látom magam minden fajban, és minden fajt látok magamban. Nem érzem magányosnak és elszigeteltnek magam, mivel egy vagyok a világegyetem minden létezőjével.

(Harang)

\section{Megérintem a földet, és többé nem hiszem, hogy azonos vagyok ezzel a testtel, és hogy életem ideje véges.}

(Harang. Mindenki megérinti a földet.)

Látom, hogy ez a test, amely földből, vízből, levegőből és tűzből épül fel, valójában nem azonos velem, s hogy ez a test nem jelenti a határaimat. Része vagyok szellemi és vér szerinti őseim életfolyamának, mely évezredek óta áramlik, mire a jelenbe ér, és évezredekig folyik még a jövőben is. Egy vagyok az őseimmel. Egy vagyok az összes emberrel és az összes fajjal, akár békésen és félelem nélkül élnek, akár szenvedéssel és félelemmel teli az életük. Ebben a pillanatban is mindenütt jelen vagyok ezen a bolygón. Jelen vagyok a múltban és a jövőben is. E test felbomlása nem érint engem, éppúgy, ahogy a virág lehullása nem jelenti a szilvafa elmúlását. Úgy tekintek magamra, mint egy hullámra az óceán felszínén, s az én valódi természetem az óceán vize. Látom magam az összes többi hullámban, és látom, hogy minden hullám bennem van. A hullám formájának megjelenése és eltűnése nincs hatással az óceánra. Dharmatestemet és szellemi életemet nem érinti élet és halál. Látom, amint jelen voltam, mielőtt a testem alakot öltött, s hogy az után is jelen leszek, amikor a test felbomlik. Ebben a pillanatban is látom, hogy nem ebben a testben létezem. Nem hetven vagy nyolcvan esztendő az én életem. Az életem - akár egy falevélé vagy Buddháé - határok nélküli. Túlléptem azon az elképzelésen, hogy csupán egy test vagyok, mely térben és időben elkülönül az élet többi formájától.

(Három lélegzet. Harang. Mindenki feláll, és egymás kezét fogva élvezi a légzést.) ${ }^{113}$

113 http://www.szelidmosoly.hu/index.php/tanitas/gyakorlatok/19-a-fold-harom-erintese (Utolsó letöltés: 2016. február 20.) 


\section{II. függelék: Képek}

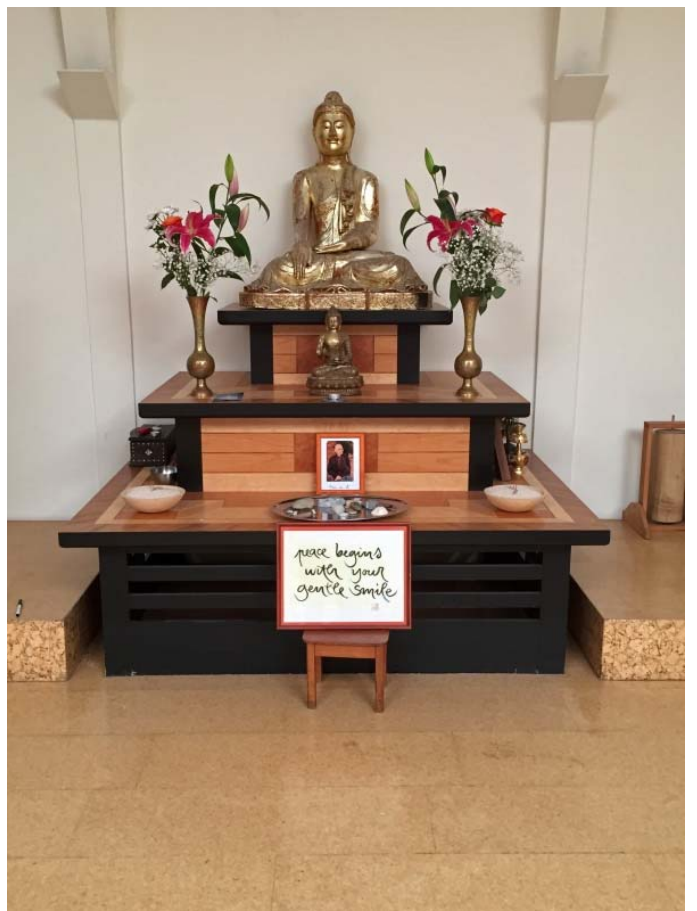

1. kép

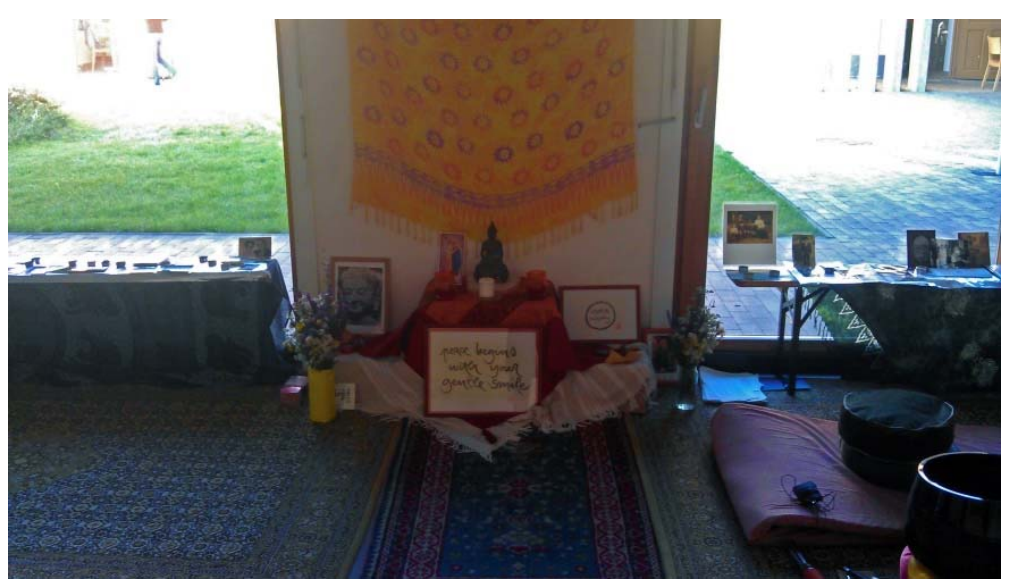

3. kép

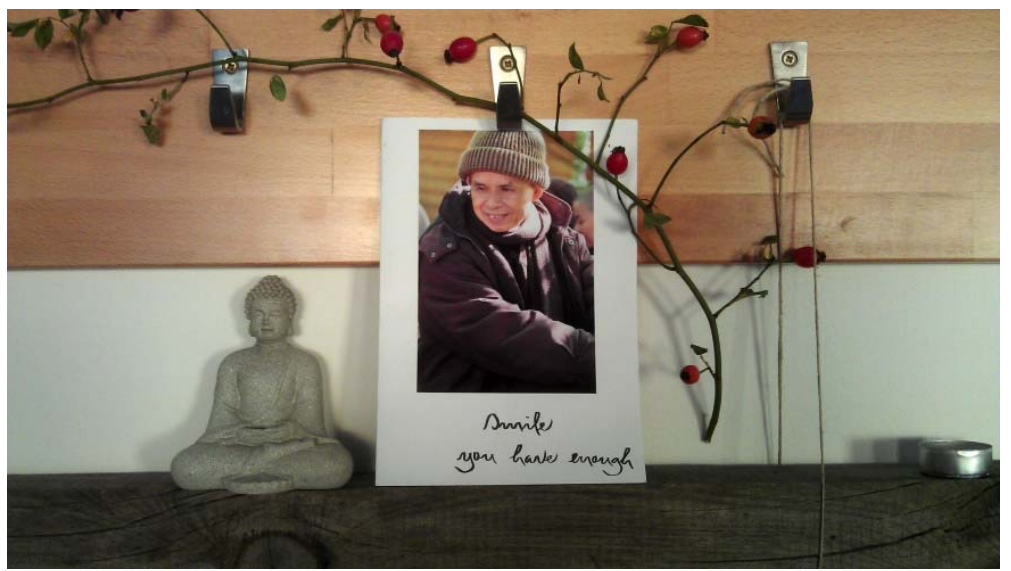

4. kép

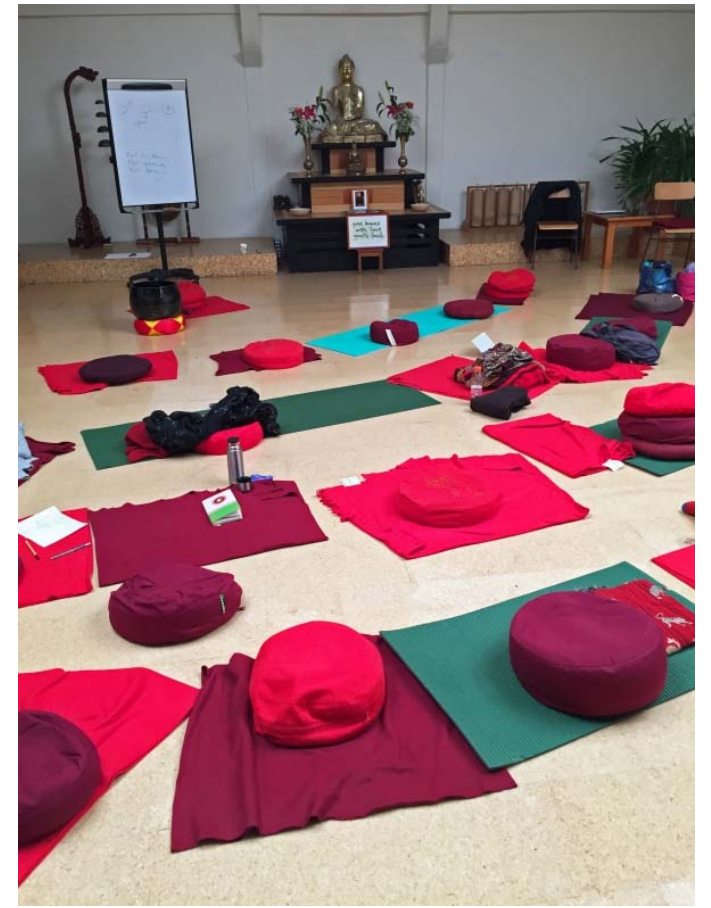

2. kép

1. kép:

Oltár a Tan Kapuja Buddhista Főiskola Szertartástermében (2016. február)

2. kép:

A zendó elrendezése Dharma-tanításhoz (2016. február)

\section{3. kép:}

Oltár a zendóban

Pannonhalmán (2014. augusztus)

\section{4. kép:}

Thich Nhat Hanh képe a pannonhalmi zendóban (2014. augusztus) 


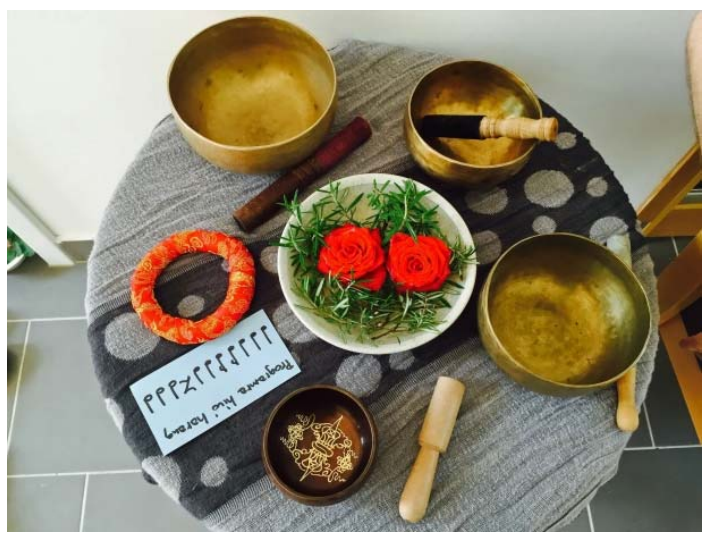

5. kép

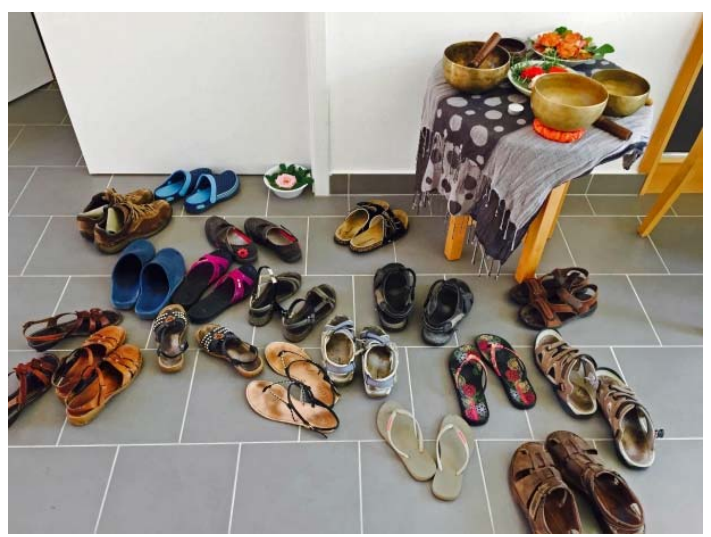

6. kép

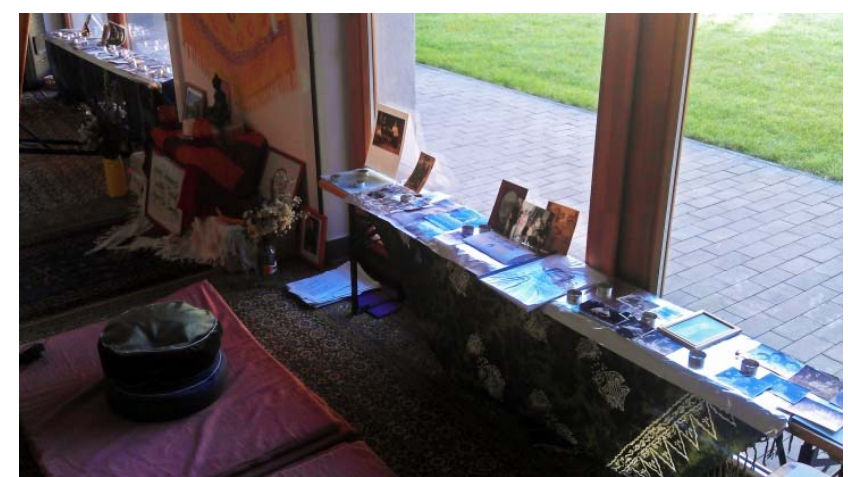

7. kép



8. kép

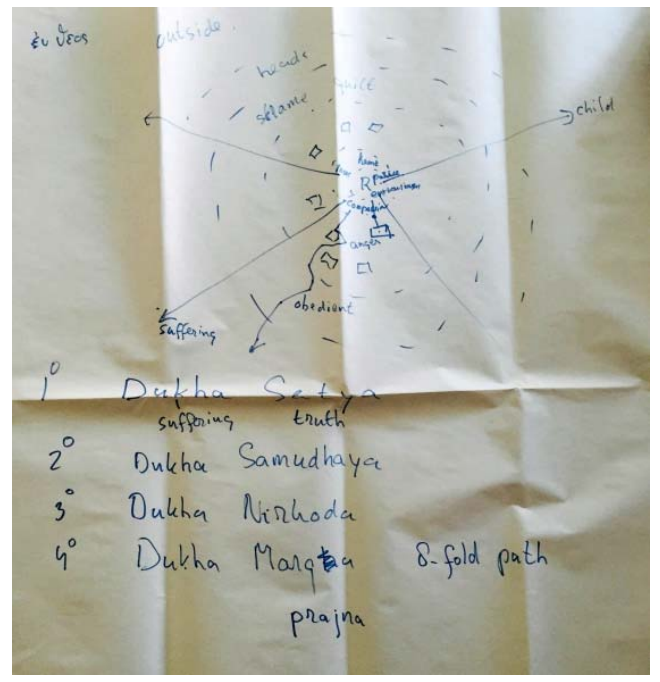

9. kép

5. kép: Programra hívó harangok Pannonhalmán (2015. június)

6. kép: Átmeneti tér a szakrális térbe való belépés előtt (2015. június)

7. kép: Az Ősök-szertartáshoz berendezett zendó egy részlete

(2014. augusztus)

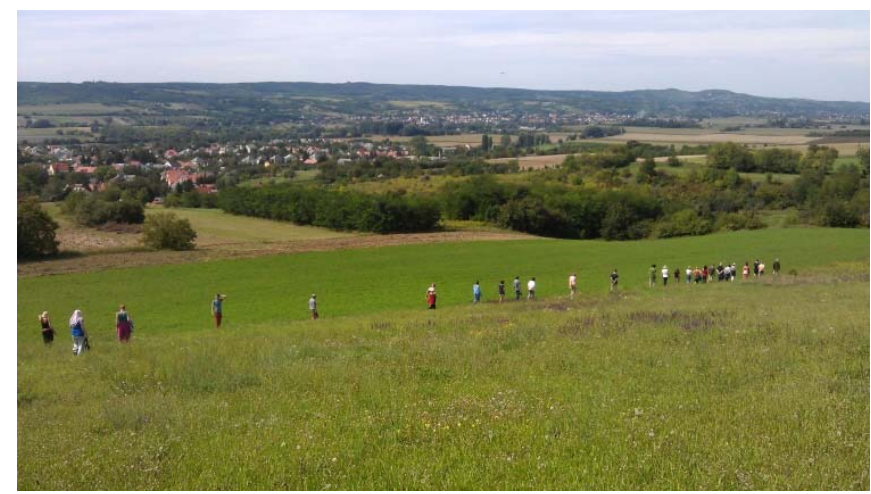

8. kép: Dharma-tanításhoz berendezett zendó Budapesten, a Tűzmadár Házban (2015. március)

9. kép: Dharma-tanítás jegyzete (2015. június)

10. kép (legalul): Sétáló meditáció (2014. augusztus) 


\section{III. függelék: Interjúkérdések}

Az alábbiakban az interjúkat vezető kérdések szerepelnek. Mivel az interjúk mélyinterjúk voltak, Heltai és Tarjányi leírásának ${ }^{114}$ megfelelően inkább hallgatni igyekeztem, semmint beszélni. Ezért az interjú elején elmondtam, milyen kérdéscsoportokat állítottam össze, és azokon belül miről szeretnék beszélni. Ezután elindítottam az interjút az első kérdéssel, a továbbiakban pedig az alkalmas pillanatokban és szükség szerint újabb kérdéseket tettem fel. Ezek nem mindig egyeztek meg a leírt kérdésekkel, hanem illeszkedtek az adott beszédfolyamhoz. A kérdésekre nem egy-egy néhány mondatos választ vártam, hanem szerettem volna megérteni a megkérdezett motivációit, betekinteni a sajátvilágába, megismerni az attitűdjeit, értékeit, problémamegoldási módszereit, felkészültségeit. Ennek megfelelően az elkészült interjúk inkább élettörténeteket tártak fel különböző mélységekben, és meglehetősen változatosan alakultak a megkérdezett személyiségének megfelelően. A viszonylagos strukturálatlanság mellett azonban az interjúkban többnyire sikerült minden kérdést érintenünk.

\section{Az interjúk alapjául szolgáló kérdések:}

\section{Bevezető kérdések}

- Hogyan kerültél kapcsolatba a buddhizmussal?

- Hogyan kerültél kapcsolatba a szanghával? Más szanghában is jártál már? Melyik tetszik legjobban, és miért?

- Mióta vagy tagja a szanghának? Hogyan jellemeznéd a részvételed szintjét? Elégedett vagy ezzel a szinttel?

\section{Vallásosságra vonatkozó kérdések}

- Vallásos voltál-e korábban, és ha igen, milyen felekezethez tartozónak tekintetted magad?

- Gyakorlod-e a vallásodat a buddhizmuson kívül?

\footnotetext{
114 „A jó »beszélőkének« semmi köze a jó mélyinterjúhoz, annál több köze van ehhez a hallgatásnak. Ez a legfontosabb teendője a mélyinterjúzónak. Leülni a kérdezettel és hallgatni, amit mond. Elsősorban hallgatni kell és mindaddig, amíg lehet." (Heltai-Tarjányi, p. 3.)
} 
- Jelent-e neked bármilyen problémát ezek összeegyeztetése? Ha igen, milyeneket?

\section{A közösségi élettel kapcsolatos kérdések}

- Mennyire fontos számodra, hogy egy buddhista közösség tagja légy? Szükségesnek tartod a közösségben való tagságot a buddhizmus gyakorlásához?

- Mit ad neked a közösség?

- Mit hiányolsz a közösségi életből?

- Mit adnak neked az elvonulások?

- Mennyire fontos a tanító szerepe számodra és a közösségben? Mennyire jelent problémát neked Thich Nhat Hanh vagy Jan változtatgatása?

A nyelvi és kulturális dimenziókkal kapcsolatos kérdések

- Mennyire szoktad tanulmányozni a buddhista irodalmat? Fontos számodra, hogy ilyen jellegű ismeretek birtokában légy?

- Szerinted mennyire érted meg magyarul a buddhista tanításokat, hiányzik neked valami a nyelvi korlátok miatt?

- Mennyire érted meg Jant angolul? Mit gondolsz a tanításai fordításáról? Átjön a lényeg, vagy néha/gyakran hiányzik valami?

- Vannak olyan dolgok akár a buddhizmusban, akár Jan tanításaiban, amelyek kulturálisan furcsák neked? Mit tudsz kezdeni ezekkel?

- Mennyire érzed megvalósíthatónak a buddhizmus elvei szerinti életet Magyarországon? Milyen problémákat látsz ebben, és mire ad esetleg választ a buddhizmus?

A mindennapi életvitellel és elkötelezettséggel kapcsolatos kérdések:

- Mennyire határozzák meg a buddhizmus elvei a mindennapi életviteledet?

- Mennyire és hogyan építed be a mindennapi életviteledbe a gyakorlást? Milyen területeken gyakorolsz leginkább?

- Szembesülsz-e konfliktusokkal a buddhizmus/buddhistaság miatt (a család, barátok, munkatársak, egyéb hétköznapi kötelezettségek körében)? Ha igen, milyenekkel? 
- Hogyan oldod fel ezeket a konfliktusokat? Milyen módszereid vannak a feloldásra, és ezeket mennyire érzed sikeresnek? Hogyan érzed magad, ha sikeresen feloldottál egy ilyen konfliktust, és hogyan, ha nem?

- Milyen olyan hétköznapi problémákkal szembesülsz, amelyek megoldásában a buddhizmust hívod segítségül? 


\section{Bibliográfia}

Assmann, Jan [2004]: A kulturális emlékezet. Írás, emlékezés és politikai identitás a korai magaskultúrákban. Atlantisz Könyvkiadó, Budapest.

BAUBERGER, STEFAn SJ [2014]. Nyitottan a teljességre. Keresztény hit, zen gyakorlatok. Jézus Társasága Magyarországi Rendtartománya, Budapest.

BERGER, PETER L. [2006]: A vallás és a Nyugat. = Beszélő, 2006. január. pp. 28-34.

BERNARD, JEFF [1999]: A nyelvi relativizmus Rossi-Landi-féle kritikája újraolvasva. Szemiotikai vizsgálódás. In Neumer Katalin (ed.): Nyelv, gondolkodás, relativizmus. Osiris Kiadó, Budapest. pp. 167-201.

BIRKÁS ANNA [2007]: Egy budapesti muszlim közösség megközelítése a térhasználat értelmezésén keresztül. In A. Gergely András - Papp Richárd (ed.): A szakralitás arcai - Vallási kisebbségek, kisebbségi vallások. Nyitott Könyvműhely. pp. 79-97.

Bishop, Peter [1993]: Dreams of Power. Tibetan Buddhism and the Western Imagination. The Athlone Press, London.

BLACK, MaX [1998]: A nyelv labirintusa. Holnap Kiadó.

BoRGES, JoRGE LUIS [1999]: A John Wilkins-féle analitikus nyelv. In Jorge Luis Borges válogatott művei. Az örökkévalóság története. Esszék. Európa Könyvkiadó, Budapest. pp. 276-81.

Borges, Jorge LuIs [2009]: Seven Nights. New Directions Publishing Corporation, New York.

BudA BÉLA [1986]: A közvetlen emberi kommunikáció szabályszerüségei. Animula, Budapest.

Buddharakkhita, Acharya [1989]: Metta -The Philosophy and Practice of Universal Love. Buddhist Publication Society, Kandy, Sri Lanka. 
CAmpbell, Colin [2010]: The Easternization of the West: Or, How the West was Lost. Asian Journal of Social Science Vol. 38 5. pp. 738-57. DOI: 10.1163/156853110X522911

Chenu, M. D. [1999]: Aquinói Szent Tamás és a teológia. Szent István Társulat, Budapest.

Coleman, James William [2002]: The New Buddhism: The Western Transformation of an Ancient Tradition. Oxford University Press, New York.

CSÁNYI VILMOS [2000]: Van ott valaki? Typotex.

DOMSCHITZ MÁTYÁS-HAMP GÁBOR [2006]: A kommunikáció színtereiről. In Horányi Özséb et al.: A kommunikáció mint participáció. AKTI-Typotex, Budapest. pp. 101-173.

DuRKHEIM, ÉMILE [2004]: A vallási élet elemi formái. L'Harmattan Kiadó.

Eliade, Mircea [1998]: Vallási hiedelmek és eszmék története I. A kőkorszaktól az eleusziszi misztériumokig. Budapest, Osiris.

Eliade, Mircea [2014]: A szent és a profán. Budapest, Helikon Kiadó.

FARKAS ATTILA MÁRTON [1998]: Buddhizmus Magyarországon avagy az alternatív vallásosság egy típusának anatómiája. MTA PTI Etnoregionális Kutatóközpont, Budapest. http://mek.oszk.hu/10700/10732/10732.pdf (Utolsó letöltés: 2016. február 20.)

FAURE, BERNARD [2012]: A gray matter. Another look at Buddhism and neuroscience. Tricycle (The Buddhist Review), Winter 2012.

Fromm, Erich-Suzuki, Daisetz Teitaro [1989] Zen-buddhizmus és pszichoanalízis. Helikon Kiadó, Budapest.

GEERTZ, ClifFord [1994a]: Az ethosz, a világkép és szent szimbólumok elemzése. In Az értelmezés hatalma. Antropológiai írások. Századvég, Budapest. pp. 7-25.

GEERTZ, ClifFord [1994b]: Sűrű leírás. Út a kultúra értelmező elméletéhez. In Az értelmezés hatalma. Antropológiai írások. Századvég, Budapest. pp. 194-226. 
GidDEnS, Anthony [2003]: Szociológia. Osiris Kiadó, Budapest.

GRIFFITHS, BEDE [2006]: Kelet és Nyugat házassága. Filosz Kiadó, Budapest.

HABERMAS, JÜRGEN [2008]: A szekularizáció dialektikája (állampolgári egyenlőség és kulturális különbözőség). Lettre 71. szám, 2008. tél. http://epa.oszk.hu/00000/ 00012/00055/habermas.htm (Utolsó letöltés: 2016. február 20.)

Hamilton, Malcolm [2002]: The Easternisation Thesis: Critical Reflections. Religion (2002) 32, 243-58 DOI:10.1006/reli.2002.0429

HELTAI ERZSÉBET-TARJÁNYI JóZSEF [1999]: A szociológiai interjú (mélyinterjú) készítése. http://www.tarki.hu/adatbank-h/kutjel/html/a509.html (Utolsó letöltés: 2016. február 20.)

HETÉNYI ERNő (ed.) [1997]: Buddhista lexikon. Trivium Kiadó.

HoRÁNYI ÖzSÉB [2006]: Bevezető. In Horányi Özséb et al. [2006]: A kommunikáció mint participáció. AKTI-Typotex, Budapest. pp. 11-16.

HoRÁNYI ÖZSÉB-SZABÓ LEVEnTE [2006]: A kommunikáció ágenséről. In Horányi Özséb et al. [2006]: A kommunikáció mint participáció. AKTI-Typotex, Budapest. pp. 175-235.

INGOLD, Tim [2004]: A fordítás művészete egy folytonos világban. In N. Kovács Tímea [ed.]: A fordítás mint kulturális praxis. Jelenkor kiadó, Pécs. pp. 47-71.

James, William [2009]: The Varieties Of Religious Experience. A Study In Human Nature. University of Adelaide e-book. https://csrs.nd.edu/assets/ 59930/williams_1902.pdf (Utolsó letöltés: 2016. február 20.)

Johnston, William [2003]: Christian Zen. Fordham University Press, New York.

KAMARÁS ISTVÁN [2002]: Új vallási jelenségek Magyarországon. Globalizáció és helyi sajátosságok. In Kovács János Mátyás (szerk.): A zárva várt Nyugat. Kulturális globalizáció Magyarországon. 2000 / Sík Kiadó, Budapest. pp. 189-215. 
KÁRPÁTY ÁGNES [2001]: Buddhizmus Magyarországon avagy egy posztmodern szubkultúra múltja és jelene. MTA PTI Etnoregionális Kutatóközpont. Munkafüzetek. Budapest.

KÉZDI NAGY GÉZA (ed.) [2008]: A magyar kulturális antropológia története. Bevezetés. Budapest, Nyitott Könyvmúhely.

Koné, Alioune [2006]: Le Zen en Europe : Un état des lieux. Un Zen Occidental, Párizs. http://www.zen-occidental.net/pdf/kone01.pdf (Utolsó letöltés: 2016. február 20.)

KoRPICS MÁRTA-P. SZILCZl DóRA [2007]: Miért kommunikáció, miért szakrális? In Korpics Márta - P. Szilczl Dóra (szerk.): Szakrális kommunikáció. Budapest, Typotex, 2007. pp. 11-36.

KRÁNITZ MiHÁLY-SzOPKó MÁRK [2001]: Teológiai kulcsfogalmak szótára. Szent István Társulat, Budapest.

LEEUW, GERARDUS VAN DER [2001]: A vallás fenomenológiája. Osiris Kiadó, Budapest.

LovÁsz IRÉN [2002]: Szakrális kommunikáció. Budapest, Európai Folklór Intézet.

LOY, DAVID R. [2004]: What's Buddhist about Socially Engaged Buddhism. http://www.zen-occidental.net/articles1/loy12-english.html (Utolsó letöltés: 2016. február 12.)

LuCKMANN, Thomas [1996]: A láthatatlan vallás. A vallás fenomenológiája. Lettre 23. szám, 1996. tél. http://epa.oszk.hu/00000/00012/00007/02luck.htm (Utolsó letöltés: 2016. február 20.)

LuTZ, Antoine-Dunne, John D.-DAvidson, RichaRd J. [2007]: Meditation and the Neuroscience of Consciousness. In Zelazo, P.-Moscovitch, M.-Thompson, E. (eds.): Cambridge Handbook of Consciousness. Cambridge University Press, 2007. http://brainimaging.waisman.wisc.edu/ lutz/Meditation_Neuroscience_2005_ AL_JDD_RJD_2.pdf (Utolsó letöltés: 2016. február 20.)

MARSHALL, GoRDOn [1998]: Oxford Dictionary of Sociology. Oxford University Press. 
MÁTÉ-TóTH ANDRÁs [2013]: Vallási kommunikáció és vallási diskurzus. Magyar Vallástudományi Társaság-L'Harmattan Kiadó.

MÁTÉ-TóTH ANDRÁS-MEZEI BALÁZS [megjelenés alatt]: Vallástudományi kézikönyv. Magyar Vallástudományi Társaság.

Mikulas, William L. [2007]: Buddhism and Western Psychology: Fundamentals of Integration. Journal of Consciousness Studies 2007, 14 (4), pp. 4-49.

N. KovÁcs TímeA [2004]: Kultúrák, szövegek és határok: a fordítás. In N. Kovács Tímea [ed.]: A fordítás mint kulturális praxis. Jelenkor kiadó, Pécs. pp. 5-21.

NEUMER KatAlin [1999]: Nyelv, gondolkodás, relativizmus. Filozófiai vizsgálódás. In Neumer Katalin (ed.): Nyelv, gondolkodás, relativizmus. Osiris Kiadó, Budapest. pp. 11-34.

Nhat Hanh, Thich [2003]: A béke légy te magad. Ursus Libris, Budapest.

Nhat Hanh, Thich and the Monks and Nuns of Plum Village [2007]: Chanting from the heart. Buddhist Ceremonies and Daily Practices. Parallax Press, Berkeley.

Niedermüller PÉTER [1999]: A kultúraközi kommunikációról. In Béres István Horányi Özséb (szerk.): Társadalmi kommunikáció. Osiris Kiadó, Budapest, pp. 96-111.

OtTo, Rudolf [2001]: A Szent. Az isteni eszméjében rejlő irracionális és viszonya a racionálishoz. Osiris Kiadó, Budapest.

PETE KRISZTIÁN-P. SZILCZL DóRA [2006]: A kommunikáció intézményeiről. In Horányi Özséb et al.: A kommunikáció mint participáció. AKTI-Typotex, Budapest. pp. 17100.

PlÉH CSABA [1999]: Hozzájárulhatnak-e az empirikus pszichológiai kutatások a nyelv-gondolkodás viszony filozófiai problémájának megoldásához? In Neumer Katalin (ed.): Nyelv, gondolkodás, relativizmus. Osiris Kiadó, Budapest. pp. 35-165.

PRESSING LajOS [1998]: Buddhista meditációs technikák mentálhigiénés hatásai. A Magyar Integratív Pszichoterápiás Egyesület 1998. október 23-i tudományos ülésén elhangzott előadás. http://dakiniland.net/egyebek/pszichologia/ 
irasok/buddhista-meditaciok-mentalhigienes-hatasa (Utolsó letöltés: 2016. február 20.)

Quaglia, JoRdan T. [2011]: Theoretical and Methodological Contributions of Buddhism to Psychology and Neuroscience. VESAK 2011, The $8^{\text {th }}$ Conference of the United Nations Day of Vesak. Buddhist Virtues in Socio-Economic Development. http://www.undv.org/vesak2011/panel4/06QuagliaFINAL.pdf (Utolsó letöltés: 2016. február 20.)

Stark, Rodney-Glock, Charles Y.: Piety [1968]: The Nature of Religious Commitment. Volume One. University of California Press, Berkeley-Los Angeles.

SZILÁGYI ZsOlt-HidAS GERgELY [2013]: Buddhizmus. Magyar Vallástudományi Társaság-L’Harmattan Kiadó, Budapest.

TomkA MikLós [1996]: A vallásszociológia új útjai. Replika, 1996. május. pp. 163-71.

ToMkA MikLós [2010]: Vallási helyzetkép - 2009. In Rosta Gergely - Tomka Miklós (szerk.): Mit értékelnek a magyarok? Az Európai Értékrend Vizsgálat 2008. évi magyar eredményei. OCIPE Magyarország-Faludi Ferenc Akadémia, Budapest. pp. 401-25.

TÖRÖK PÉTER [2004]: Magyarországi vallási kalauz 2004. Akadémiai Kiadó, Budapest. TRÍAS, EugENIO [2006]: Gondolatok a vallásról: a szimbólum és a szentség. In Korpics Márta - P. Szilczl Dóra (szerk.): Szakrális kommunikáció. Budapest, Typotex, 2007. pp. 191-202.

Tweed, Thomas A. [1999]: Night-Stand Buddhists and Other Creatures: Sympathizers, Adherents, and the Study of Religion. In Queen, ChristopherWilliams, Duncan Ryūken: American Buddhism: Methods and Findings in Recent Scholarship. Curzon Press, Richmond Surrey. pp. 71-90.

Wallace, B. Alan - Shauna L. Shapiro [2006]: Mental Balance and Well-Being: Building Bridges Between Buddhism and Western Psychology. American Psychologist vol. 61, no. 7, pp. 690-701. DOI: 10.1037/0003-066X.61.7.690 
Watanabe, Shogo [2005]: Compassion (Karuṇā) and Pity (Anukampā) in Mahāyāna Sūtras. = Journal of International Philosophy, No.4 2015. pp. 267-72.

WEBER, MAX [2005]: Vallásszociológia. A vallási közösségek típusai. Helikon Kiadó.

WEBER, MAX [2007]: Világvallások gazdasági etikája. Gondolat Kiadó - ELTE Társadalomtudományi Kar, Budapest. 


\section{A szerző publikációi a témában}

\section{FOLYÓIRAT}

HuSZÁR ORSOLYA [2009]: A kommunikációs jelenségek hatóköre - műhelybeszélgetés egy kommunikációs könyv kapcsán. JEL-KÉP, 2009/3, pp. 73-77.

HuSZÁr ORSOLYA [2017]: Az elvonulás mint kommunikációs színtér. JEL-KÉP, megjelenés alatt.

HuSZÁR ORSOLYA [2017]: „Résztvevő” tolmácsolás egy buddhista közösségben. JEL-KÉP, megjelenés alatt.

\section{IDEGEN NYELVÛ́ FOLYÓIRAT}

HuSZÁr ORSOLYA [2016]: The Role of Silence at the Retreats of a Buddhist Community. KOME - An International Journal of Pure Communication Inquiry 2016, Vol. 4 (2), pp. 59-73. DOI: 10.17646/KOME.2016.25 